ROGER DE MELO RODRIGUES

\title{
A VÍTIMA E O PROCESSO PENAL BRASILEIRO: \\ Novas perspectivas
}

\author{
Dissertação de Mestrado
}

Orientador: Professor Titular Antônio Scarance Fernandes

UNIVERSIDADE DE SÃO PAULO

FACULDADE DE DIREITO

São Paulo-SP

2012 
ROGER DE MELO RODRIGUES

\section{A VÍTIMA E O PROCESSO PENAL BRASILEIRO:}

Novas perspectivas

Dissertação apresentada à Banca Examinadora da Faculdade de Direito da Universidade de São Paulo (FADUSP), como requisito essencial à concessão de grau de mestre em Direito Processual (subárea: Processo Penal), elaborada sob a orientação do Professor Titular Antônio Scarance Fernandes. 
ROGER DE MELO RODRIGUES

\section{A VÍTIMA E O PROCESSO PENAL BRASILEIRO:}

Novas perspectivas

Dissertação apresentada à Banca Examinadora da Faculdade de Direito da Universidade de São Paulo (FADUSP), como requisito essencial à concessão de grau de mestre em Direito Processual (subárea: Processo Penal), elaborada sob a orientação do Professor Titular Antônio Scarance Fernandes.

Data de Aprovação:

\section{Nome:}

Título:

Instituição:

Nome:

Título:

Instituição:

Nome:

Título:

Instituição: 
Ao Deus todo-amoroso, causa primeira e fim último, que me presenteou com o dom da vida, e que não cessa de guiar-me afetuosamente pelas veredas da existência.

À minha amada esposa Jólia, incentivadora primeira e constante, devotada companheira de estudos, que me abriu os olhos ao verdadeiro sentido de todas as coisas, com quem partilhar a vida é um doce e inigualável privilégio.

Às minhas filhas, Maria Clara e Maria Cecília, que conseguem fazer-me transcender às limitações e imperfeições desse mundo, dando prova cabal de que a estagnação é um erro, de que a transformação é possível, e de que o milagre se oferece na medida de nossa perseverança.

Aos meus amados pais, José e Eremita, paradigmas incomparáveis de amor e de dedicação, que moldaram a pessoa, o cidadão e o profissional que hoje sou.

Aos demais familiares (irmãos, sogros, avós, sobrinhos $e$ cunhados), que tanto me ajudam no meu aprendizado constante. 


\section{AGRADECIMENTOS}

Ao Professor Titular Antônio Scarance Fernandes, cuja excelência acadêmica dispensa qualquer apresentação, pela pronta disponibilidade e pelo inestimável apoio dispensado por ocasião da orientação neste trabalho.

Ao Professor Dr. Rogério Lauria Tucci, exemplo de jurista e de mestre, referência imprescindível nas letras processuais penais brasileiras, e ao Professor Titular José Rogério Cruz e Tucci, por toda a atenção e auxílio prestados.

Ao Ministério Público do Rio Grande do Norte, especialmente, ao ProcuradorGeral de Justiça, Manoel Onofre de Souza Neto, à Procuradora-Geral de Justiça Adjunta, Mildred Medeiros de Lucena, e à Procuradora de Justiça, Darci de Oliveira, pelo apoio institucional necessário à realização deste projeto. 


\section{RESUMO}

O presente trabalho objetiva contribuir para a concretização de um processo penal atento às novas perspectivas trazidas pelo movimento vitimológico, assegurando-se o devido respeito às vítimas de delito e a seus interesses, evitando-se a vitimização secundária. Para tanto, parte de uma análise da atual configuração do processo penal brasileiro, e com apoio em uma pesquisa da literatura jurídica existente, dos documentos internacionais e da legislação estrangeira acerca da matéria, propõe-se uma leitura processual mais conformada com a dignidade da pessoa da vítima, revisitando diversos institutos, lançando questionamentos e mesmo expondo algumas sugestões para modificações no ordenamento jurídico nacional. As proposições levadas a cabo neste trabalho buscam o resgate da dignidade das vítimas de delito e sua participação efetiva no processo, sem implicar um retrocesso no que concerne aos direitos e garantias já assegurados ao acusado. Percebe-se que a inserção da vítima como sujeito processual acaba por conferir um efeito humanizador ao processo penal, dando seguimento à humanização iniciada pelo iluminismo penal, em relação ao acusado. De tudo isso, resulta um processo penal mais evoluído, que tem por foco central o ser humano, e que se transforma em um instrumento de promoção da cidadania por ocasião da violação dos bens jurídicos mais caros à sociedade, tutelados pela norma penal.

Palavras-chave: Movimento vitimológico. Dignidade da pessoa da vítima. Humanização. Processo penal. 


\begin{abstract}
This paper aims to contribute to the achievement of a criminal procedure aware of the new perspectives brought by victimologic movement, ensuring due respect for the victims of crime and their interests, avoiding secondary victimization. To this end, part of an analysis of the current configuration of the Brazilian criminal procedure, and support in a survey of the literature existing, international documents and foreign law on the subject, we propose a procedural reading conformed to the dignity of the victim, revisiting several institutes, casting questions and even exposing some suggestions for changes in national law. The propositions carried out this work, seek to rescue the dignity of victims of crime and them effective participation in the process, without implying a setback with respect to the rights and guarantees already provided to the accused. Realizes that the insertion of the victim as a subject gives a humanizing effect to the criminal procedural, following up the humanization initiated by the Enlightenment criminal, relative to the defendant. Thereof, results in a more advanced criminal procedure, which is the central focus of human being, and that becomes an instrument for the promotion of citizenship at the time of the violation of legal goods more expensive to society, protected by the criminal laws.
\end{abstract}

Idex terms: Victimologic movement. Dignity of the victim. Humanization. Criminal procedure. 


\section{SUMÁRIO}

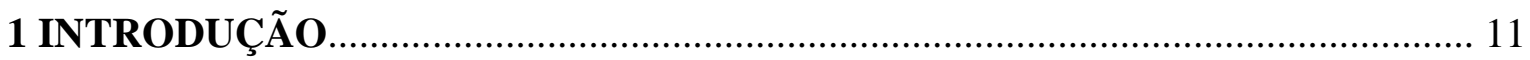

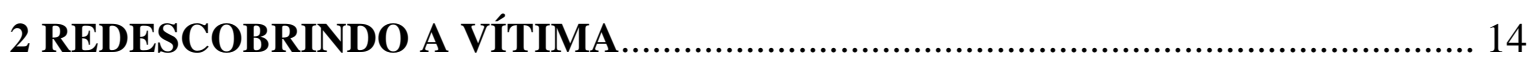

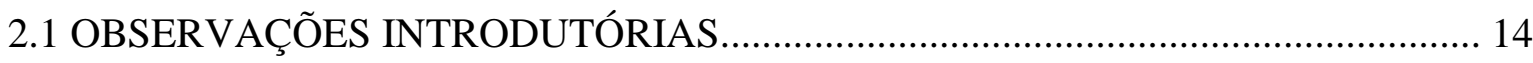

2.2 QUEM É A VÍTIMA: PRIMEIRAS APROXIMAÇÕES CONCEITUAIS.................... 14

2.3 UM OLHAR HISTÓRICO SOBRE A VÍTIMA....................................................... 17

2.3.1 Protagonismo

2.3.2 Neutralização

2.3.3 Redescoberta ou movimento vitimológico........................................................... 28

2.4 REDESCOBRINDO A VÍTIMA NO PROCESSO PENAL BRASILEIRO.................. 35

2.4.1. $O$ conceito de vítima no âmbito do processo penal brasileiro............................... 36

2.4.2 A vitimização secundária.................................................................................. 39

2.4.3 O princípio da dignidade da pessoa humana e a vítima........................................ 42

2.4.4 Aperfeiçoando a tutela da vítima no processo penal.............................................. 46

3 DIREITOS DA VÍTIMA À PROTEÇÃO E À INFORMAÇÃO................................ 51

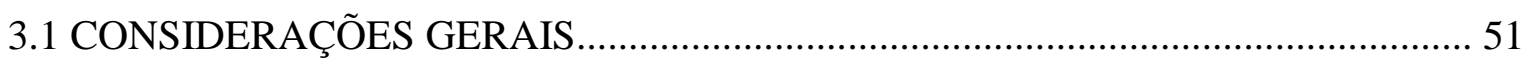

3.2 DIREITO DA VÍTIMA À PROTEÇÃO............................................................... 52

3.2.1 O direito da vítima à proteção no atual processo penal brasileiro …………….... 52

3.2.2 Novas perspectivas sobre o direito da vítima à proteção....................................... 53

3.2.2.1 Direito a um tratamento respeitoso...................................................................... 53

3.2.2.2 Direito à proteção da segurança......................................................................... 55

3.2.2.3 Direito à proteção da honra, da imagem e da privacidade........................................ 57

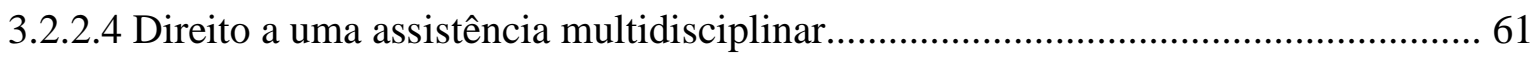

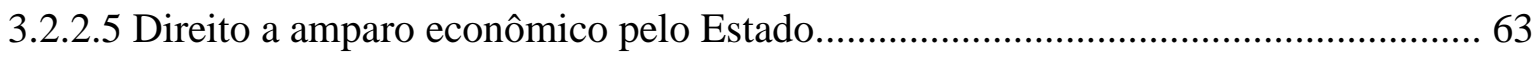

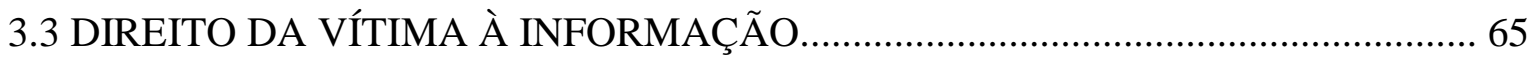

3.3.1 O direito da vítima à informação no atual processo penal brasileiro ………….... 65

3.3.2 Novas perspectivas sobre o direito da vítima à informação................................... 67

4 DIREITO DA VÍTIMA À PARTICIPAÇÃO......................................................... 75

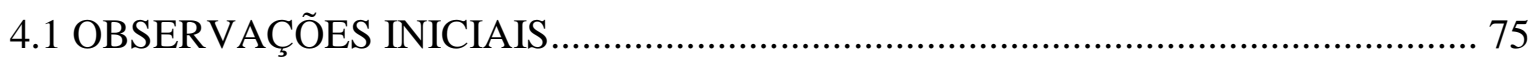

4.2 CONDICIONAMENTO À MANIFESTAÇÃO DA VÍTIMA...................................... 76

4.2.1 $\mathrm{O}$ condicionamento no atual processo penal brasileiro......................................... 76 
4.2.2 Novas perspectivas 80

4.3 CONTROLE SOBRE A ACUSAÇÃO PÚBLICA..................................................... 82

4.3.1 O controle sobre a acusação pública no atual processo penal brasileiro............ 82

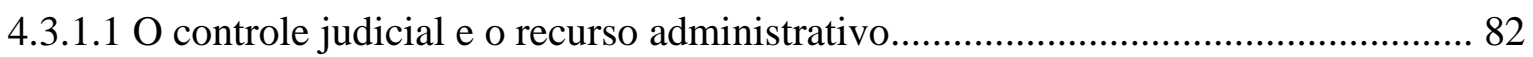

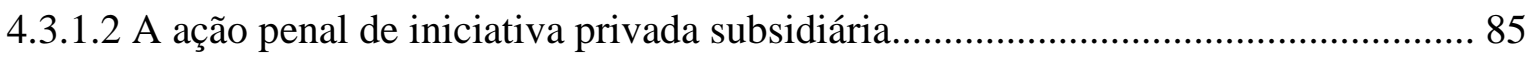

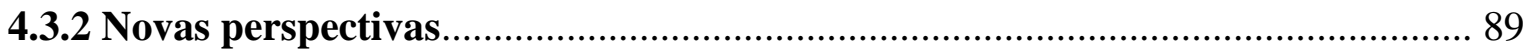

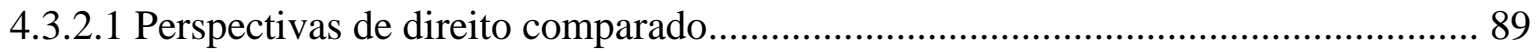

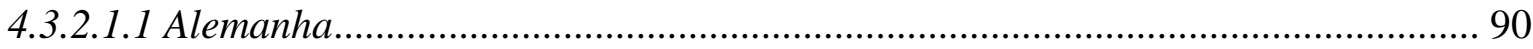

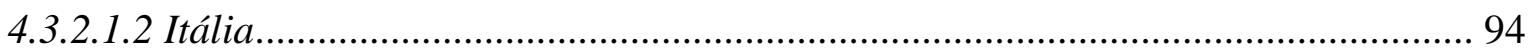

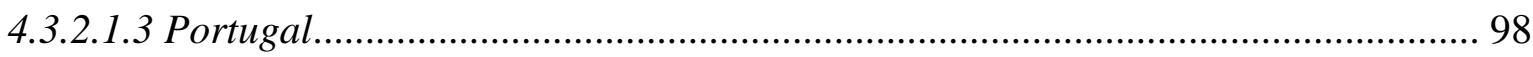

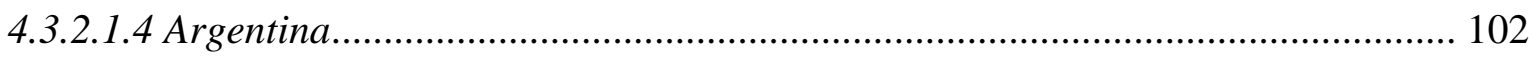

4.3.2.2 Lineamentos para um controle mais efetivo com participação da vítima.............. 105

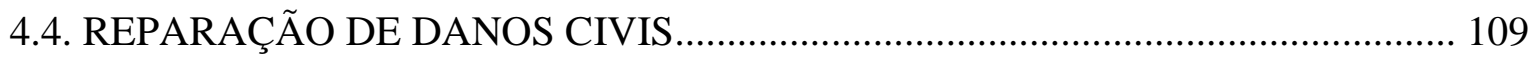

4.4.1 A reparação de danos civis no atual processo penal brasileiro.......................... 109

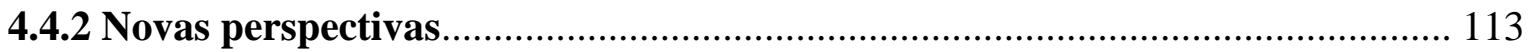

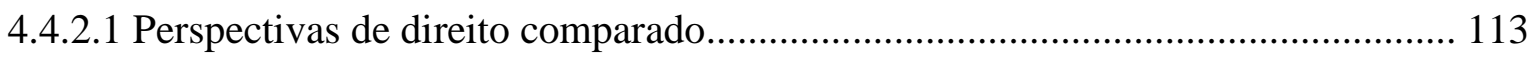

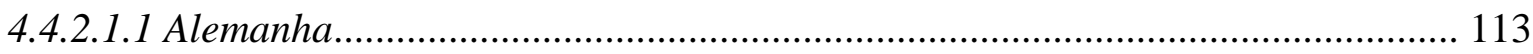

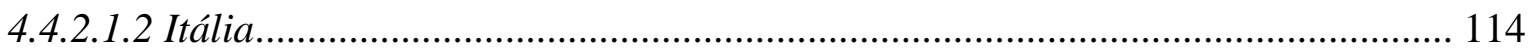

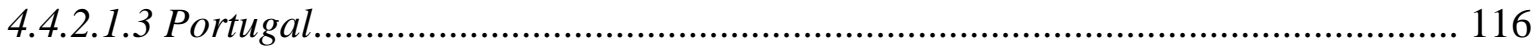

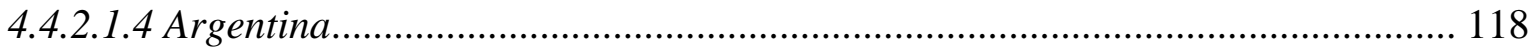

4.4.2.2 Perspectivas do Código Projetado: a introdução do sistema de adesão................. 118

4.4.2.3 Algumas considerações críticas sobre o objeto da adesão civil prevista no Código projetado.

4.4.2.3.1 A ampliação do objeto da pretensão na adesão civil: danos patrimoniais e demais danos não patrimoniais

4.4.2.3.2 A ampliação do objeto da pretensão na adesão civil: danos metaindividuais.. 125

4.5 A PARTICIPAÇÃO DA VÍTIMA NA PRODUÇÃO DE ELEMENTOS

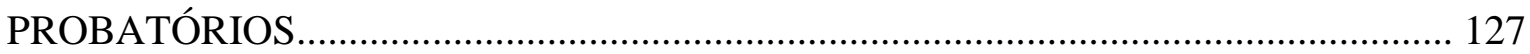

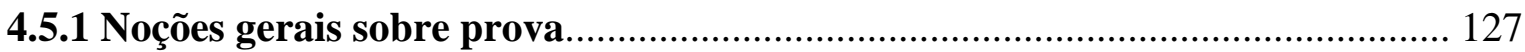

4.5.2 A participação da vítima na produção de elementos probatórios...................... 132

4.5.3 Considerações sobre a recusa da vítima em participar da produção de elementos probatórios 134

5 DIREITO DA VÍTIMA À PARTICIPAÇÃO: CONCURSO OU COOPERAÇÃO. 
5.1 NOÇÕES GERAIS

5.2 O CONCURSO (OU COOPERAÇÃO) NO ATUAL PROCESSO PENAL BRASILEIRO: O ASSISTENTE.

5.2.1 Buscando uma categoria jurídica: parte ou terceiro? ...................................... 140

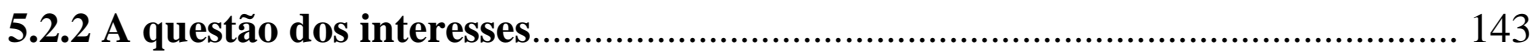

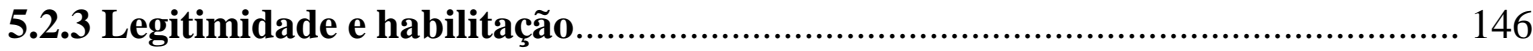

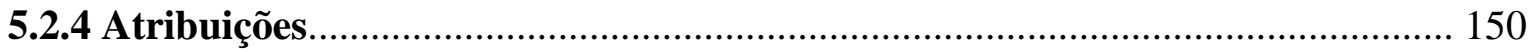

5.3 NOVAS PERSPECTIVAS PARA O ASSISTENTE............................................... 155

5.3.1 Perspectivas de direito comparado e dos órgãos internacionais........................ 155

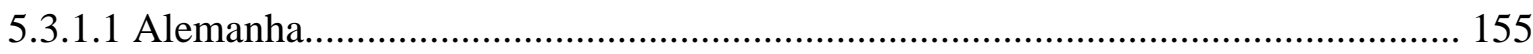

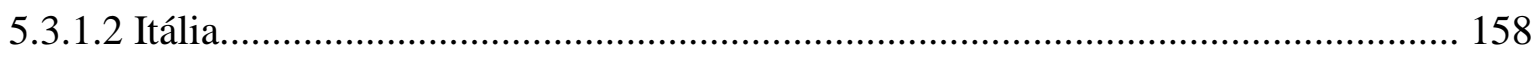

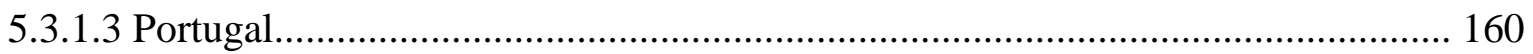

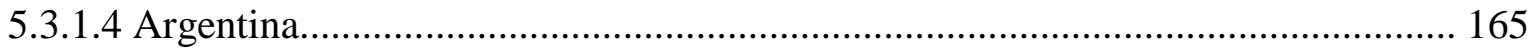

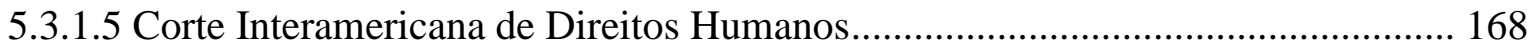

5.3.1.6 Tribunal Penal Internacional (TPI) ................................................................... 173

5.3.2 Identificando o fundamento para a participação do assistente no processo penal:

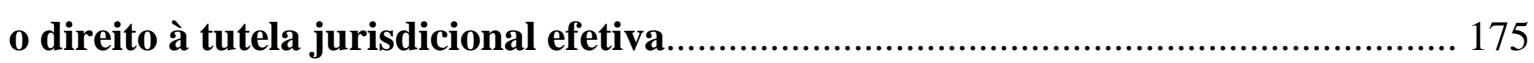

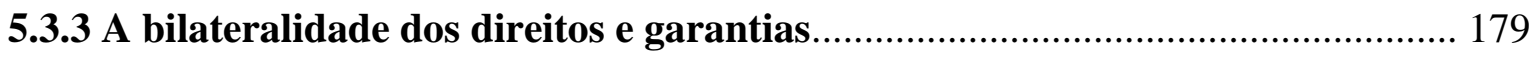

5.3.4 Analisando a questão da isonomia processual................................................... 184

5.3.5 Analisando o monopólio da ação penal de iniciativa pública............................ 189

5.3.6. O protagonismo da vítima: apontamentos sobre modificações na conformação

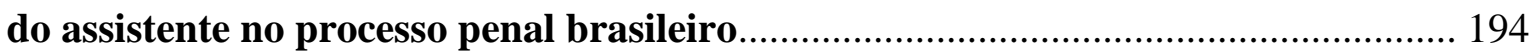

5.3.7 O assistente no Código projetado: a perda de uma oportunidade..................... 205

6 DIREITO DA VÍTIMA A UMA SOLUÇÃO CONSENSUAL DO PROCESSO.. 209

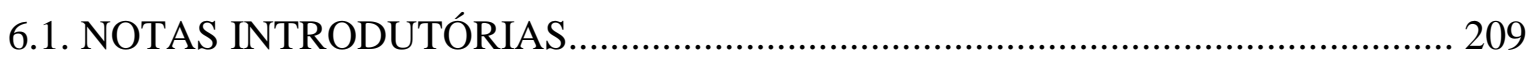

6.2 O CONSENSO NO PROCESSO PENAL E A VÍTIMA............................................ 209

6.2.1 O modelo clássico de processo penal e a diversificação..................................... 209

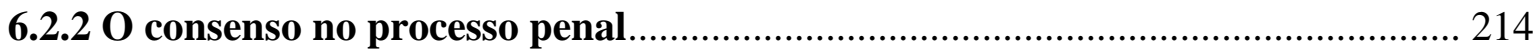

6.2.3 A vítima e o consenso: o estabelecimento de um direito................................... 217

6.2.4 A vítima e os institutos consensuais no atual processo penal brasileiro............ 219

6.3 JUSTIÇA RESTAURATIVA: UMA BREVE APRESENTAÇÃO........................... 223

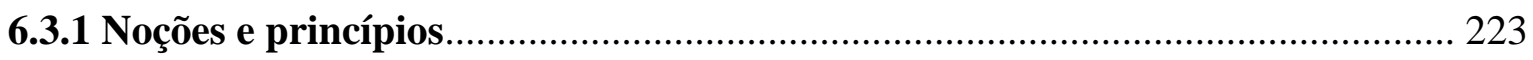

6.3.2 $O$ ideal de restauração e os sujeitos do processo restaurativo........................... 229

6.3.3 Justiça restaurativa no Brasil: uma possibilidade.......................................... 234 
CONCLUSÕES.

236

REFERÊNCIAS

245 


\section{INTRODUÇÃO}

Uma ainda que breve aproximação histórica do sistema processual inquisitorial, herdado da justiça eclesiástica medieval na Europa, faz recordar uma concepção fundamentalista em que a verdade sobrepunha-se ao homem e sua dignidade, não passando esse de mero objeto de investigação a fim de se descobrir a veracidade dos fatos.

O poderio do monarca e de sua justiça em burocratização crescente contrastava com a fragilidade do acusado, de modo que o processo penal, em verdade, não passava de um instrumento para a afirmação social da supremacia do soberano e de seus interesses.

O Século das Luzes, dentre suas contribuições, engendrou o iluminismo penal, cujos ideais começaram por insuflar um novo espírito no processo penal, de caráter notadamente humanizador.

Sob a concepção moderno-iluminista, o processo penal converteu-se no procedimento prévio e necessário para que se decida ou não pela aplicação de sanções penais pelo Estado, colocando-se como uma verdadeira limitação ao ius puniendi estatal, limitação essa que se traduz em diversos direitos e garantias em prol do ofensor e de sua dignidade, a qual se pretende contrapor em face do poderio estatal.

Seguindo tal ideal humanitário, por muito tempo o processo penal limitou-se a esse confronto entre Estado e acusado, em que as vítimas concretas restaram abstraídas, sendo seus interesses forçosamente absorvidos pelos interesses do próprio Estado, o que bem pode ser constatado a partir do desenvolvimento inicial da teoria do bem jurídico. A vítima, personagem originário e central do conflito penal, viu-se afastada do processo, falando-se, não sem razão, em um roubo do conflito penal perpetrado pelo Estado contra as vítimas de infração penal.

Com o desenvolvimento da Vitimologia e do movimento vitimológico (fase da redescoberta da vítima), o olvidamento processual da vítima mostrou-se manifesto, evidenciando-se os efeitos deletérios dessa exclusão. Esse fenômeno passou a ser identificado como um novo processo de vitimização, denominado vitimização secundária, o qual precisava ser enfrentado. As legislações nacionais em geral e mesmo as normas internacionais, atentas a esses questionamentos, passaram a buscar um maior amparo às 
vítimas de delito, e mesmo, sua inserção mais efetiva no processo penal, assegurando-lhe o status de protagonista.

Esse despertar para as vítimas representa uma evolução do processo penal, provocada, na verdade, por um desdobramento posterior do espírito humanizador insuflado pelo iluminismo penal que ontem buscava o reconhecimento da dignidade do acusado e hoje busca o reconhecimento da dignidade das vítimas de infração penal.

Sob esse prisma, se o processo penal mostrava-se como algo maior do que a afirmação de supremacia estatal, por envolver o ser humano-acusado, sua dignidade e seus interesses, agora também deve ser concebido como algo maior do que a simples resolução formal de um conflito entre Estado e acusado, tendo em vista a necessária inserção do ser humano-vítima, bem como também de sua dignidade e de seus interesses.

O presente trabalho, sob o impulso desse movimento vitimológico, tem por escopo analisar novas perspectivas para a vítima especificamente dentro do ramo do Direito Processual Penal, no contexto normativo jurídico brasileiro, buscando seu aperfeiçoamento.

Propõe-se, inicialmente, que seja lançado um olhar histórico sobre o tema, identificando-se e analisando-se as fases do status da vítima, e realçando-se o atual momento em que se preconiza sua redescoberta (movimento vitimológico).

Após, assimiladas as concepções sobre a vítima - tema indispensável para o desenvolvimento do presente estudo -, buscar-se-á entender o conceito de vitimização secundária e identificar tal fenômeno no processo penal brasileiro tal qual configurado juridicamente na atualidade. Uma vez constatada tal vitimização, sugere-se o Princípio da Dignidade da Pessoa Humana como o fundamento para seu enfrentamento, alicerçando-se daí as proposições para o aperfeiçoamento da tutela pró-vítima no processo penal brasileiro.

Para conferir um caráter mais didático ao estudo, dividir-se-ão os direitos da vítima nos seguintes grupos: direito à proteção, direito à informação, direito à participação e direito a uma solução consensual do processo, grupos esses sobre os quais se proporá um estudo sob dois pontos de vista, basicamente: o primeiro, consistente em uma ótica sobre o agrupamento de direitos da vítima (proteção, informação, participação e solução consensual do processo) sob sua configuração atual no processo penal brasileiro; o segundo, concernente a novas perspectivas que podem ser colhidas da própria literatura jurídica, de documentos internacionais, de algumas normas jurídicas alienígenas 
selecionadas e mesmo da legislação nacional projetada, visando sempre ao aperfeiçoamento da tutela processual pró-vítima atualmente existente no país.

Toma-se, assim, por foco inicial, o panorama atual do processo penal brasileiro concernente às vítimas de infração penal, apontando-lhe, sob uma ótica crítica, questionamentos sobre suas limitações, sem o olvidamento de referências às suas vantagens. E com base nessa pesquisa encetada, propõe-se uma leitura processual mais em conformidade com a dignidade da vítima, no que se lançam, no desenvolvimento deste trabalho, diversas sugestões de modificação do ordenamento jurídico processual penal brasileiro ora vigente. 


\section{REDESCOBRINDO A VÍTIMA}

\subsection{OBSERVAÇÕES INTRODUTÓRIAS}

O tema do redescobrimento da vítima no processo penal já vem sendo debatido e aprofundado por estudiosos de diversos países há algum tempo, mais precisamente, após a segunda metade do século XX. Não obstante esse tema já ter sido também alvo de debate na doutrina brasileira, a posição da vítima sob a atual configuração do processo penal no ordenamento jurídico brasileiro ainda deixa a desejar, despertando a necessidade de se intensificar essa postura de redescoberta no contexto nacional.

Partindo-se desse entendimento, no presente capítulo, busca-se inicialmente formar noções conceituais de quem seja a vítima no processo penal, tarefa imprescindível para o desenvolvimento deste estudo. Assimiladas tais noções conceituais, passa-se a uma digressão sobre as fases relativas ao status da vítima penal ao longo da história, evidenciando-se, assim, a fase da redescoberta (movimento vitimológico).

Em seguida, após um necessário aprofundamento das noções conceituais anteriormente levantadas, parte-se para uma análise do conceito de vitimização secundária (sobrevitimização), o que possibilitará a identificação de tal fenômeno no processo penal brasileiro.

Uma vez constatada a vitimização secundária no processo penal brasileiro, propõe-se um estudo sobre o Princípio da Dignidade da Pessoa Humana, o qual ora se coloca como a base jurídica para o resgate da vítima do estado de vitimização antes apontado. É justamente esse princípio que servirá como pedra angular para a análise posterior sobre a necessidade de aperfeiçoamento da tutela da vítima no processo penal brasileiro, tema inicialmente discutido neste capítulo, mas que ganhará nos capítulos seguintes o seu devido desenvolvimento sob contornos mais robustos.

\subsection{QUEM É A VÍTIMA: PRIMEIRAS APROXIMAÇÕES CONCEITUAIS}


Consoante já referido, para o desenvolvimento do presente estudo faz-se imprescindível a análise sobre a concepção de vítima, imprimindo-se aqui um esforço de aproximação conceitual. Deve-se asseverar, a princípio, que a palavra vítima ganha conceitos bem diversificados, o que se explica à luz da perspectiva em que aquela é tomada como objeto de estudo. ${ }^{1}$

Captando esses variados significados, BITTENCOURT, que publicou a primeira obra de Vitimologia no Brasil (Vítima), já mencionava os diversos sentidos que poderiam advir de tal vocábulo, que estabeleceu em número de cinco: a) sentido originário ("pessoa ou animal sacrificado à divindade"), b) sentido geral ("pessoa que sofre os resultados infelizes dos próprios atos"); c) sentido jurídico-geral ("aquele que sofre diretamente a ofensa ou ameaça ao bem tutelado pelo Direito”); d) sentido jurídico penalrestrito ("indivíduo que sofre diretamente as conseqüências da violação da norma penal"); e) sentido jurídico-penal amplo ("o indivíduo e a comunidade que sofrem diretamente as conseqüências dos crimes"). ${ }^{2}$

Etimologicamente, segundo MANZANERA, o vocábulo deriva da palavra latina victima, designando "la persona o animal sacrificado o que se destina al sacrificio". 3 Por sua vez, conforme FERNANDES, referida palavra latina pode ter derivado de termos como vincire, que significa atar ou ligar - em referência aos animais destinados a sacrifício aos deuses após a guerra -, vincere, que significa vencer, sendo a vítima o vencido, e vigere, que evoca a ideia de vigor e de força, também referente ao animal a ser sacrificado, de porte mais robusto, em oposição ao termo hostia, que designava o animal de menor porte. ${ }^{4}$

Sob o prisma da Vitimologia ${ }^{5}$, podem ser vislumbradas perspectivas que abrangem o termo vítima em sentido amplo, incluindo-se, além das vítimas penais, vítimas não penais e vítimas de fatos fortuitos.

Desse grupo participariam MENDELSOHN, ANYIAR DE CASTRO e BITTENCOURT, que, segundo MANZANERA, concebem o termo vítima sob três planos ou acepções: a) bio-psico-social (que envolve todos os fatores que podem estimular o

\footnotetext{
1 "São diversos os conceitos de vítima. Eles dependem do ponto, perspectiva, foco ou do estudo que é realizado sobre a mesma." (CALHAU, Lélio Braga. Vítima e direito penal. 2. ed. Belo Horizonte: Melhoramentos, 2003, p. 21).

${ }^{2}$ BITTENCOURT, Edgar de Moura. Vítima. 2. ed. São Paulo: LEUD, 1978, p. 79.

${ }^{3}$ MANZANERA, Luis Rodriguez. Victimología. 12. ed. Cidade do México: Porrúa, 2010, p. 63.

${ }^{4}$ FERNANDES, Antônio Scarance. O papel da vítima no processo criminal. São Paulo: Malheiros, 1995, p. 30-31.

${ }^{5}$ As origens da Vitimologia serão objeto de considerações a posteriori, por ocasião da análise histórica sobre a redescoberta da vítima.
} 
sujeito a converter-se em vítima, como o crime, acidentes de trabalho ou de trânsito, inclusive se o sujeito for vítima de si próprio - victima independiente), b) criminológico (no qual o problema da personalidade da vítima guardaria relação biopsicossocial somente com o conjunto de problemas da criminalidade, do ponto de vista terapêutico e de prevenção vitimal), c) jurídico (trata da vítima em relação à lei, penal ou civil, para os casos de ressarcimento de danos por ela sofridos). ${ }^{6}$

Destaque-se, também, a existência de concepções mais restritivas, que reduzem o termo vítima apenas ao contexto criminológico, como o fazem ELLENBERGER, GOLDSTEIN e FATTAH. ${ }^{7}$

É preciso asseverar que, para os fins deste trabalho - o qual trata da vítima no âmbito do processo penal -, devem ser abandonados conceitos alheios ao viés jurídico, como os de conotação vitimológica ou criminológica, que situam a vítima sob outro enfoque necessariamente distinto da perspectiva adotada pelo Direito, sob pena de se incorrer em distorções indesejadas.

Assim, não se pode perder de vista uma conceituação estritamente jurídica. Para tal conceituação, deve-se ter em mente os destacados sentidos jurídico-geral, jurídico-penal-amplo e jurídico-penal-restrito, referidos por BITTENCOURT.

Com base em tais sentidos, destaca-se, em um primeiro momento, que o termo vítima, mesmo em sua acepção jurídica, pode ganhar conotações diversas em razão do tipo de abordagem, pois a abordagem penal sobre a vítima diverge de abordagens extrapenais, como as que podem ser verificadas no âmbito do Direito Civil e do Direito do Trabalho, por exemplo.

Também não se deve olvidar que, mesmo sob um viés jurídico-penal, a concepção sobre vítima pode exibir uma abrangência maior ou menor, o que será melhor analisado a posteriori.

\footnotetext{
${ }^{6}$ MANZANERA, Luis Rodriguez. Victimología. 12. ed. Cidade do México: Porrúa, 2010, p. 36-37.

${ }^{7}$ Interessante observar que, segundo as observações de MANZANERA, o conceito de vítima ensejou intensa discussão nos primeiros simpósios internacionais de Vitimologia. Resumindo as observações do citado autor, no I Simpósio, em Jerusalém (1973), deu-se ênfase a um conceito amplo, buscando-se ampliar a concepção bidimensional (vítima - vitimário) para uma concepção multidimensional; após uma tendência a restringir a Vitimologia à Criminologia, verificada em Boston (1976), retornou-se, em Münster (1979), ao enfoque dado em 1973; no Japão, (1982), concluiu-se pela esterilidade do debate, deixando-se ao alvedrio dos estudiosos a escolha pela concepção do termo e pela autonomia da ciência vitimológica; na Iugoslávia (1985), o debate se reacendeu, travando-se entre os expansionistas e os demais participantes. De qualquer forma, cientificismos à parte, os simpósios internacionais de Vitimologia têm apresentado em suas pautas assuntos relacionados à vitimização em geral, não se restringindo ao aspecto criminológico. Por exemplo, no Simpósio em Mito (2009), abordou-se a questão da vitimização de indígenas e de outros grupos marginalizados, bem como a resposta à vitimização em casos de desastre. Cf. MANZANERA, Luis Rodriguez. Victimología. 12. ed. Cidade do México: Porrúa, 2010, p.30-31; 438-480.
} 
O que importa, por ora, é registrar a necessidade de uma aproximação conceitual de cunho mais estrito (jurídico) sobre a vítima para os fins deste estudo, reservando-se a tópico posterior um maior aprofundamento mediante a análise de conceitos jurídico-penais. $^{8}$

\subsection{UM OLHAR HISTÓRICO SOBRE A VÍTIMA}

Em que pese existir um discreto sentimento de menoscabo quanto a abordagens sob a perspectiva histórica em trabalhos jurídicos, entende-se que tal perspectivação se mostra fundamental não somente para viabilizar uma compreensão mais rica do tema afinal, capta-lhe seu enraizamento histórico -, mas também para evitar eventual risco de uma ótica unilateral, impregnada de cerrado dogmatismo jurídico, divorciada do contexto da realidade histórico-social. ${ }^{9}$

Para um olhar histórico sobre a vítima, impende que sejam feitas algumas considerações prévias. Primeiramente, cabe a advertência de que embora se esteja a falar, neste item, sobre a vítima em uma acepção de cunho jurídico-penal, ou em termos mais claros, sobre as vítimas da prática de delito, nem sempre o comportamento antissocial humano foi rotulado como delito ao longo da história.

A conduta que hoje pode ser revestida de tipicidade jurídico-penal antes era concebida de modo diverso, como, por exemplo, ofensa aos deuses, dano a determinados membros da comunidade ou à comunidade inteira. Isso porque a sistematização do Direito Penal e o conceito de crime são formulações de origem recente.

Cabe assinalar ainda que a análise histórica proposta a seguir cinge-se, grosso modo, ao contexto do Velho Continente, ressalvadas referências esparsas a contextos diversos.

Por fim, sem qualquer pretensão de esgotamento na abordagem, segue-se um apanhado baseado na tradicional análise acerca do status da vítima ao longo da história,

\footnotetext{
${ }^{8}$ Trata-se do item 2.4.1, situado neste capítulo.

${ }^{9}$ Sobre a importância da análise histórica de qualquer tema: "O homem, no dizer de Ortega y Gasset, não tem natureza, tem história, sendo que o passado, a experiência anterior, deságua e forma o presente, pois somos hoje a consequência do que já havíamos sido." (REALE JÚNIOR, Miguel. Teoria do delito. 2. ed. São Paulo: Revista dos Tribunais, 2000, p. 17).
} 
dividida por MOLINA em três fases: protagonismo, neutralização e redescobrimento. ${ }^{10}$

\subsubsection{Protagonismo}

O protagonismo ou idade de ouro da vítima compreende um largo período histórico, que teria se iniciado nos primórdios da humanidade, passando pelo primitivo Direito Romano e estendendo-se até a Idade Média, de modo que um lapso temporal tão dilatado que abrange o desenvolvimento de civilizações tão diversas, por si só já revela a dificuldade, senão a impossibilidade, de uma devida sistematização. ${ }^{11}$

De qualquer modo, tal fase encontra-se associada à ideia de um acentuado poder de disposição da vítima (e de seu grupo social) quanto à persecução e à imposição de um castigo, em contraposição a uma sociedade cuja organização político-repressiva mostrava-se ausente ou, no mínimo, incipiente.

$\mathrm{O}$ primeiro momento histórico que caracteriza a idade de ouro da vítima consiste no surgimento das primeiras sociedades humanas. No seio desses agrupamentos cujas relações sociais eram rudimentares, a primeira resposta social ao ilícito consistiu na vingança, que se mostrava mais consentânea com os impulsos mais naturais do homem.

Essa vingança privada, embora exercida pela vítima e por seus parentes, transcendia uma importância meramente individual e particular, ganhando verdadeira

${ }^{10}$ Cf. MOLINA, Antonio Garcia-Pablos de. Criminologia: uma introdução a seus fundamentos teóricos. Tradução de Luiz Flávio Gomes. São Paulo: Revista dos Tribunais, 1992, p. 42. Faz-se importante ainda frisar que qualquer tentativa de aproximação histórica acerca do papel ou do status da vítima penal há de considerar a existência de grande variedade de agrupamentos e sociedades humanas e de suas respectivas e peculiares ordens jurídicas, o que enseja necessariamente uma abordagem genérica que possa abranger caracteres e fenômenos culturais que guardem certa uniformidade entre si, acarretando, de certo modo, a perda da riqueza e do colorido dos sistemas sociais em particular.

${ }^{11}$ Tal período não representa uma continuidade, de forma que CÂMARA qualifica a idade de ouro como um "segmento temporal deveras fluído e difuso que surge com os primeiros raios da alvorada da civilização, depois reaparece no primitivo Direito romano e alcança o seu apogeu na Alta Idade Média - Direito dos povos germânicos - vindo depois a perder densidade (em decorrência de seguidas tentativas de publicização da reação penal) ao final da Idade Média [...]”. (CÂMARA, Guilherme Costa. Programa de política criminal orientado para a vítima do crime. São Paulo: Editora Revista dos Tribunais; Coimbra: Coimbra Editora, 2008, p. 31.) Tal fluidez, difusão e descontinuidade levam ao questionamento quanto a se tratar a idade de ouro de uma fase histórica específica. A expressão original (the golden age of the victim), segundo MOLINA, foi cunhada por SCHAFER (Cf. a nota 41 em: MOLINA, Antonio Garcia-Pablos de. Criminologia: uma introdução a seus fundamentos teóricos. Tradução de Luiz Flávio Gomes. São Paulo: Revista dos Tribunais, 1992, p. 42), e referia-se, conforme CÂMARA, especificamente à compensação pelos prejuízos causados pelos crimes, presente no direito germânico medieval: cf. nota 40 em CÂMARA, Guilherme Costa. Programa de política criminal orientado para a vítima do crime. São Paulo: Editora Revista dos Tribunais; Coimbra: Coimbra Editora, 2008, p. 31. 
dimensão social.

De fato, embora coubesse à vítima e aos seus a aplicação do castigo como represália pelo mal sofrido, essa prática era não só tolerada, mas estimulada pelo próprio grupo, como um mecanismo de controle social dos seus membros. Em uma perspectiva mais aprofundada, a prática da vingança como instrumento de controle social, servia naquelas primeiras sociedades, como garantia da própria sobrevivência do grupo e, mais especificamente, da manutenção da forma de estruturação do poder adotada naquele determinado agrupamento. ${ }^{12}$

Cumpre considerar que em um estágio ainda inicial de organização social, o castigo a ser obtido pela vingança privada aparentemente não encontrava limites, ensejando frequentes excessos, o que se denomina vingança de sangue. Ocorre que o desmedido revide da vítima invariavelmente ensejava uma nova vingança por parte do agressor original e assim sucessivamente em um círculo de violência que se autoalimentava e expunha a grande risco o próprio grupo social envolvido.

Um questionamento apropriado, proposto por CÂMARA, consiste em saber se nessa fase protojurídica havia alguma forma de controle normativo que incidisse sobre o exercício dessa vingança. Com apoio em CARBASSE, pondera aquele que uma anomia (ausência de regras) mostrar-se-ia por demais teórica, indicando a necessidade de um controle, ainda que sob a forma de mecanismos rudimentares, para a conservação daquelas primeiras formas de organização social, donde conclui pela existência de primitivos costumes emanados da experiência coletiva. ${ }^{13}$ Possivelmente, dentre tais costumes, estaria inserido uma norma básica, limitando o poder de resposta (vingança) ao ofendido individualmente e a seu grupo social (família, clã ou tribo), afastando-se a ingerência de terceiros.

Um marco no desenvolvimento de mecanismos limitadores da vingança privada consistiu na Lei do Talião (lex talionis), presente no Código de Hammurabi. ${ }^{14}$ Por

\footnotetext{
12 "Deste modo, toda sociedade tem uma estrutura de poder (político e econômico) com grupos mais próximos e grupos mais marginalizados do poder, na qual, logicamente, podem distinguir-se graus de centralização e de marginalização. Há sociedades com centralização e marginalização extremas, e outras em que o fenômeno se apresenta mais atenuado, mas em toda sociedade há centralização e marginalização de poder." (destaques do autor). (ZAFFARONI, Eugenio Raúl; PIERANGELLI, José Henrique. Manual de direito penal brasileiro: parte geral. 8. ed. rev. atual. São Paulo: Revista dos Tribunais, 2009. v. 1, p. 58).

${ }^{13}$ Cf. CÂMARA, Guilherme Costa. Programa de política criminal orientado para a vítima do crime. São Paulo: Editora Revista dos Tribunais; Coimbra: Coimbra Editora, 2008, p. 23.

14 A Lei do Talião, que pode ser considerada como uma assimilação primitiva do princípio da proporcionalidade, tem seu primeiro registro escrito, ao que tudo indica, no Código de Hammurabi (cerca de 1700 a.C.), sendo reproduzida em normas posteriores da Antiguidade, como a legislação mosaica (Levítico, 24; 19-20). Precedendo historicamente o referido Código caldeu, registram-se outras normas que já
} 
tal expressão designa-se uma regra que garante proporcionalidade ao castigo a ser aplicado (não mais que olho por olho, dente por dente e vida por vida), ${ }^{15}$ estabelecendo um limite mais preciso e seguro para a aplicação de sanções. Aponta-se, como decorrência da lex talionis, uma necessidade de reparação do dano, ${ }^{16}$ que assumia muitas vezes a feição de uma reparação monetária à vítima, com vistas ao retorno do status quo ante ou como mecanismo de compensação. ${ }^{17}$

Nesse ponto, pode-se afirmar que a partir da implementação de normas que garantissem limites e proporcionalidade às sanções, tão bem representada pela Lei do Talião, a vingança privada, até então exteriorizada pela vingança de sangue, passa a ceder espaço à justiça privada, em que um membro da comunidade ou autoridade pública passa a ser responsável por assegurar a observância de tais normas. ${ }^{18}$

Outro contexto histórico tradicionalmente apontado como manifestação evidente do protagonismo da vítima, pode ser buscado no primitivo Direito Romano. ${ }^{19}$

Em um estágio inicial, impunham-se regras que se traduziam em costumes (mos morum) e em normas de cunho religioso (ius sacrum) ${ }^{20}$ Sob o cotejo de tais normas,

estabeleciam um disciplinamento para a vingança de sangue, em sociedades já organizadas politicamente, como o Código de Ur-Nammu e as Leis de Eshnunna, ambas datando de aproximadamente 2000 a.C. (cf. PIEDADE JÚNIOR, Heitor. Vitimologia: evolução no tempo e no espaço. Rio de Janeiro: Freitas Bastos, 1993, p. 24-26), cujo teor, porém, não representou historicamente avanço tão significativo quanto o Talião.

${ }^{15}$ Elaboração proposta em CÂMARA, Guilherme Costa. Programa de política criminal orientado para a vítima do crime. São Paulo: Editora Revista dos Tribunais; Coimbra: Coimbra Editora, 2008, p. 29. A referida regra, embora seja impactante e mesmo repulsiva aos olhos do homem pós-moderno, representou um avanço inestimável no caminho para uma repressão mais justa.

16 “É preciso, contudo, matizar a assertiva supra, pondo em evidência aspecto não menos importante, qual: o princípio em apreço afirmava - e de modo bem destacado - a necessidade de reparação do dano [...]”'. (destaques nossos). (CÂMARA, Guilherme Costa. Programa de política criminal orientado para a vítima do crime. São Paulo: Editora Revista dos Tribunais; Coimbra: Coimbra Editora, 2008, p. 28-29).

17 "A noção de reparação do dano - comenta Clayton Reis - encontra-se claramente definida no Código de Hammurabi. E a idéia, hoje vigente, da reparação do dano por um valor monetário tinha como objetivo repor as coisas lesadas ao seu status quo ante ou, ainda, dar uma compensação monetária à vítima, em uma forma de, à custa da diminuição do patrimônio do lesionador, proporcionar à vítima uma satisfação compensatória." (PIEDADE JÚNIOR, Heitor. Vitimologia: evolução no tempo e no espaço. Rio de Janeiro: Freitas Bastos, 1993, p. 29-30).

${ }^{18}$ FERNANDES, Antônio Scarance. O papel da vítima no processo criminal. São Paulo: Malheiros, 1995 , p. 15.

19 "Costuma-se dividir o estudo do direito romano em dois campos: a história externa (instituições políticas, fontes de cognição do direito e jurisprudência) e a história interna (instituições de direito privado). A história externa é pesquisada segundo as diferentes formas de governo romanas: período real (das origens à queda da realeza em 510 a.C.); período republicano (de 510 a.C. a 27 a.C., quando o Senado investe Otaviano - futuro Augusto - no poder supremo com o nome de princeps); período do principado (de 27 a.C. a 285 d.C., com o começo do dominato por Diocleciano); e, período do dominato (de 285 a 565 d.C., data em que morre Justiniano). A história interna é dividida em três fases: direito antigo ou pré-clássico (das origens de Roma à Lei Aebutia, de data incerta, entre 149 e 126 a.C.); direito clássico (da Lei Aebutia até o término do reinado de Diocleciano, em 305 d.C.); e, direito pós-clássico ou romano-helênico (de 305 d.C. até a morte de Justiniano, em 565 d.C.)". (PENTEADO, Jaques Camargo. Acusação, defesa e julgamento. Campinas: Millenium, 2001, p. 15-16). 
costuma-se identificar um sistema repressivo que então vigia, partindo de uma divisão entre as transgressões conforme os interesses envolvidos: postando-se de um lado, as infrações que afetavam interesses privados, cuja repressão cabia inicialmente à vítima e aos seus, e, de outro, as infrações que afetavam interesses públicos, quase sempre associados a interesses religiosos, ${ }^{21}$ de cuja repressão incumbia-se o próprio Rei. ${ }^{22}$

Essa cisão entre ofensas a interesses particulares e a interesses públicos (de caráter religioso), que serviu, sob o Direito Romano, para uma gênese posterior dos conceitos de delicta (delitos privados) e de crimina (delitos públicos), ${ }^{23}$ mostra-se útil para apreendermos a forte influência que o princípio da religiosidade exercia nas civilizações antigas, a ponto de subtrair algumas condutas da repressão privada, transferindo-as para uma repressão social-religiosa.

Assim, sob o elemento religioso, a vingança privada chegou muitas vezes a ceder espaço a uma vingança divina, sofrendo o poder de repressão uma transferência, passando das mãos da vítima e de seu grupo social, para as mãos de uma casta sacerdotal. ${ }^{24}$ O último momento histórico a que tradicionalmente se refere à fase de protagonismo da vítima pode ser situado na Idade Média. Com o processo de decadência e queda do Império Romano do Ocidente, ${ }^{25}$ que teve como uma das causas a lenta infiltração

${ }^{20}$ Cf. TUCCI, Rogério, que, com apoio em MANZINI, afirma: "Segundo VINCENZO MANZINI [...], ao tempo da Realeza, a justiça penal em Roma era informada pelas regras do mos maiorum e do ius sacrum, sendo mesmo familiar a origem do direito de punir, que se consubstanciou longa e permanentemente no ius vitae ac necis do paterfamilias sobre os seus filhos e descendentes." (TUCCI, Rogério Lauria. Lineamentos do processo penal romano. São Paulo: Buhatsky, 1976, p. 13).

21 ANDRADE chega a apontar, ao lado de infrações de ordem privada e de infrações de ordem pública (religiosa), uma subcategoria desta última, dissociada de interesses religiosos. Seriam "aqueles crimes que não eram considerados de caráter religioso, mas que igualmente colocavam em perigo ou ofendiam a ordem pública. Entre eles estavam a proditio (conjura com o inimigo), a traição e os crimes militares. Nesses casos, o rei assumia seu papel de chefe militar, e não atuava como sacerdote. A atuação do rei, nessas hipóteses, pouco ou nada se assemelhava a uma atividade jurisdicional, pois agia como chefe militar, investido, naquele momento, da coercitio, em vez da iudicatio". (ANDRADE, Mauro Fonseca. Sistemas processuais penais e seus princípios reitores. Curitiba: Juruá, 2010, p.70).

22 ANDRADE, Mauro Fonseca. Sistemas processuais penais e seus princípios reitores. Curitiba: Juruá, 2010, p. 68-69.

${ }^{23}$ Cf. a lição de TUCCI sobre dados conceituais sobre o crime segundo o Direito Romano: TUCCI, Rogério Lauria. Lineamentos do processo penal romano. São Paulo: Buhatsky, 1976, p. 17-23.

${ }^{24}$ Sobre o tema, ROIG TORRES: "Carrara deslinda da la 'venganza privada' de la 'venganza divina', situando a ésta en uma fase posterior em la que se habría aprovechado la incultura de los hombres para que éstos dejaren de concebir el derecho de venganza como um derecho proprio y lo abandonaran en manos del clero, fenômeno que se acentuaria en épocas posteriores. La venganza privada habría precedido, pues, a la derivada del principio de religiosidad; sería aquella que se desarrolló em los primieros tiempos de la humanidad, y que surgió del puro espíritu de supervivencia de los hombres." (ROIG TORRES, Margarita. Algunos apuntes sobre la evolución histórica de la tutela jurídica de la víctima del delito. Estudios Penales y Criminológicos, Santiago de Compostela, n. 22, p.153-308, 1999/2000, p. 161). Em sentido oposto, mencionado a precedência da vingança divina sobre a vingança privada: BITTENCOURT, Cezar Roberto. Tratado de direito penal: parte geral. 9. ed. São Paulo: Saraiva, 2004. v. 1, p. 26-27.

${ }^{25} \mathrm{O}$ sistema processual penal romano, ao final do Império, exibia fortes traços inquisitoriais. Na denominada cognitio extra ordinem, a persecução e o julgamento eram monopolizados pelo Estado, restando pouco ou 
dos povos germânicos, ${ }^{26}$ verificou-se uma gradual substituição do onipotente aparato estatal romano por uma nova realidade política, marcada pela fragmentação do poder, que servirá de fundamento para o nascente sistema feudo-senhorial medieval.

O direito que regulava os diversos povos germânicos espalhados pela Europa, e que influenciou decisivamente esse meio cultural medieval, era essencialmente consuetudinário e apresentava um caráter acentuadamente privado, ambiente em que se fez ressurgir a vingança privada. Conforme CÂMARA, "praticamente todos os delitos eram vistos como meras questões privadas, i.e., suscetíveis de encontrar solução no estrito âmbito das famílias do autor e do ofendido."27

Destaca o referido autor a solidariedade como nota caracterizadora, presente entre os membros da família (Sippe) e entre os denominados amigos de sangue (Blutfreude). ${ }^{28}$ Essa solidariedade fazia com que a família inteira do ofensor respondesse por este, caso não o entregasse para sofrer a devida vingança, e conferia, por outro lado, o direito à família do ofendido de perseguir as ofensas praticadas contra seus integrantes. ${ }^{29}$

No contexto desse peculiar sistema jurídico, a prática do ilícito quebrantava as relações estabelecidas entre a família do ofendido e a família do ofensor, fazendo-se necessário o pagamento de uma quantia (Busse) por parte desta em favor daquela, prática que se dava por meio de um acordo (Wehrgeld), que restabelecia a harmonia entre os envolvidos. Em se tratando de ilícitos mais graves, disponibilizavam-se ao ofendido e à sua família as seguintes opções: ou se escolhia a aplicação de um castigo ou se optava pelo acordo (Wehrgeld), objetivando o estabelecimento de quantia a ser paga (Busse). ${ }^{30}$

Como se observa nesse direito consuetudinário dos povos germânicos, a estipulação do objeto da composição econômica competia inicialmente ao ofendido e à sua

nenhum espaço para a vítima. Para um aprofundamento, cf. TUCCI, Rogério Lauria. Lineamentos do processo penal romano. São Paulo: Buhatsky, 1976, p. 185-191. Cf. também ANDRADE, Mauro Fonseca. Sistemas processuais penais e seus princípios reitores. Curitiba: Juruá, 2010, p. 92-99.

${ }^{26}$ Cf. uma visão geral sobre os povos germânicos em: COSTA, Mário Júlio de. História do direito português. 3. ed. Coimbra: Almedina, 2009, p. 101-104.

${ }^{27}$ CÂMARA, Guilherme Costa. Programa de política criminal orientado para a vítima do crime. São Paulo: Editora Revista dos Tribunais; Coimbra: Coimbra Editora, 2008, p. 32.

${ }^{28}$ CÂMARA, Guilherme Costa. Programa de política criminal orientado para a vítima do crime. São Paulo: Editora Revista dos Tribunais; Coimbra: Coimbra Editora, 2008, p. 32.

${ }^{29}$ CÂMARA, Guilherme Costa. Programa de política criminal orientado para a vítima do crime. São Paulo: Editora Revista dos Tribunais; Coimbra: Coimbra Editora, 2008, p. 33.

${ }^{30}$ ROIG TORRES menciona que além do Busse, o ofensor pagava ao chefe da tribo um preço (Fredum), em razão da proteção oferecida pela tribo contra a vingança do ofendido e de sua Sippe: ROIG TORRES, Margarita. Algunos apuntes sobre la evolución histórica de la tutela jurídica de la víctima del delito. Estudios Penales y Criminológicos, Santiago de Compostela, n. 22, p.153-308, 1999/2000, p. 162. Para uma melhor análise sobre o direito medieval dos povos germânicos, cf. CÂMARA, Guilherme Costa. Programa de política criminal orientado para a vítima do crime. São Paulo: Editora Revista dos Tribunais; Coimbra: Coimbra Editora, 2008, p. 30-38. 
Sippe, porém, evoluiu-se para uma judicialização do conflito, passando a incumbir aos juízes a definição do que seria pago.

A essa intermediação correspondeu gradualmente, segundo ROIG TORRES, a proscrição dos castigos corporais e a aplicação da reparação econômica à maior parte dos delitos, o que resultou, sob um aspecto jurídico, na redução da intervenção da vítima no processo, por meio da limitação de sua ingerência sobre a persecução e sobre a aplicação de sanção à infração, e, sob um aspecto econômico, na perda de parcela da condenação pecuniária em favor da coletividade. ${ }^{31}$

Cabe, por fim destacar, com apoio em FERNANDES, que durante o protagonismo da vítima, "não havia ainda distinção clara entre o ilícito penal e o civil e, por isso, as punições de ordem pecuniária representavam ao mesmo tempo pena e reparação."32

\subsubsection{Neutralização}

Como se infere da fase anterior, a vingança, atribuída à vítima e aos seus, e que em alguns estágios da civilização chegou a ser confiada nas mãos de uma casta sacerdotal, passou a ceder espaço a formas de solução de conflito que contavam com a participação de um terceiro imparcial. Essa suplantação da relação bilateral ofendido/ofensor por uma relação trilateral, constituída por ofendido/ofensor/autoridade judiciária imparcial é que marca, segundo FERRAJOLI, o nascimento do Direito Penal. ${ }^{33}$

\footnotetext{
${ }^{31}$ ROIG TORRES, Margarita. Algunos apuntes sobre la evolución histórica de la tutela jurídica de la víctima del delito. Estudios Penales y Criminológicos, Santiago de Compostela, n. 22, p.153-308, 1999/2000, p. 163.

${ }^{32}$ FERNANDES, Antônio Scarance. O papel da vítima no processo criminal. São Paulo: Malheiros, 1995, p. 15.

33 " [...] a história do direito penal e da pena corresponde a uma longa luta contra a vingança. O primeiro passo dessa história ocorreu quando a vingança foi disciplinada como direito-dever privado a pesar sobre o ofendido e seu grupo de parentes, segundo os princípios da vingança de sangue e da regra do talião. $\mathrm{O}$ segundo passo, muito mais decisivo, aconteceu quando produziu-se uma dissociação entre juiz e parte lesada, e a justiça privada - as vinganças, os duelos, os linchamentos, as execuções sumárias, os ajustamentos de contas - foi não apenas deixada sem tutela, mas vetada. $\mathbf{O}$ direito penal nasce, precisamente, neste momento, quando a relação bilateral ofendido/ofensor é substituída por uma relação trilateral, que coloca em posição imparcial uma autoridade judiciária. É por isto que cada vez que um juiz é movido por sentimentos de vingança, ou de parte, ou de defesa social, ou o Estado deixa espaço à justiça sumária dos particulares, pode-se dizer que o direito penal regrediu a um estado selvagem, anterior à formação da civilização." (destaques nossos). (FERRAJOLI, Luigi. Direito e razão: teoria do garantismo penal. Tradução de Ana Paulo Zomer, Fauzi Hassan Choukr, Juarez Tavares e Luiz Flávio Gomes. São Paulo: Revista dos Tribunais, 2002, p. 269).
} 
Após a queda do Império Romano do Ocidente, assistiu-se ao surgimento de diversos núcleos de poder. Os senhores feudais exerceriam o comando político por séculos em seus territórios, em uma substituição do anterior poder universal (romano) por poderes locais. Esse poder político disperso, por sua vez, foi posteriormente substituído, de modo gradual, por um novo poder centralizado, titularizado, desta vez, não por um império de extensão territorial intercontinental, como o era o Império Romano, mas por Estados Nacionais monárquicos que passaram a se organizar em solo europeu.

Esse processo de centralização política sob Estados Nacionais dá-se através de séculos, de modo paulatino, suplantando a ainda persistente ideia do universal (herdada do Império Romano e que subsistia nas ideias de Império e de Igreja) que se contrapunha à ideia do local (resultado da fragmentação político-senhorial). ${ }^{34}$

Para uma melhor compreensão desse momento histórico, tome-se o exemplo do Estado monárquico português. Após a queda do Império Romano do Ocidente e a sucessão de processos históricos como a dominação visigótica, a Conquista moura na península ibérica, e sua Reconquista cristã, ${ }^{35}$ D. Afonso Henriques, em 1139, rompeu com o reino de Leão, declarando a independência de Portugal e autoproclamando-se Rei. Essa nascente monarquia obteve reconhecimento pelo Papa Alexandre III, em 1179, por meio da bula Manifestis Probatum.

O novel Estado português, que no século XII enfrentava o problema de uma jurisdição fracionada, a cargo de senhores locais, que ainda detinham forte influência política, no século XIII presenciou a crescente centralização do poder nas mãos do Rei e a assunção, da parte deste, do poder jurisdicional.

Assim, os monarcas portugueses passaram a adotar medidas a fim de promover essa concentração de poder, como: circular nas províncias, auxiliados por juízes itinerantes, com o intuito de fiscalizar a aplicação de sua justiça (a justiça real); nomear juízes (juízes de fora) para substituir os juízes ordinários, eleitos pela comunidade local;

\footnotetext{
34 "Juntamente com o surgimento e a justificativa deste novo exercício do poder, verificou-se a decadência de uma convicção sobre o 'universal' que havia continuado, a despeito da queda do Império Romano. A ideia de 'Império' e a ideia de 'Igreja' persistiram durante toda a Idade Média, outorgando um sentido de unidade que não poucas vezes acarretaria a luta entre o poder 'político' e o poder 'religioso' por ser a única representação desse poder na Europa. O fim dessas áreas artificialmente uniformizadas permitiriam realizar o importante processo de centralismo que iria contradizer o exercício dos poderes locais." (ANITUA, Gabriel Ignacio. Histórias dos pensamentos criminológicos. Tradução de Sérgio Lamarão. Rio de Janeiro: Revan, 2008. (Coleção pensamento criminológico, 15), p. 38).

${ }^{35}$ Uma abordagem histórica de tais feitos fugiria aos propósitos deste trabalho, contudo, pode ser encontrada em TUCCI e AZEVEDO, do domínio visigótico até os princípios do Estado português: TUCCI, José Rogério Cruz e; AZEVEDO, Luiz Carlos de. Lições da história do processo civil lusitano. São Paulo: Revista dos Tribunais, 2009, p. 21-26.
} 
instituir a apelação omisso medio (que se interpunha diretamente ao Rei, sem a intervenção do senhor local), dentre outras medidas que acabaram por solapar as justiças senhoriais e assegurar a prevalência e, a posteriori, a exclusividade da justiça real. ${ }^{36}$

Aproveitando-se do exemplo português anteriormente referido, pode-se afirmar que a centralização de poder nas mãos dos monarcas europeus necessariamente haveria de conferir a estes um monopólio sobre a jurisdição em geral e sobre o ius puniendi em particular, suprimindo-se as justiças senhoriais. ${ }^{37}$

Para tanto, procedeu-se a um processo de racionalização, definido por ANITUA como o "processo de profissionalização e burocratização dos órgãos encarregados de administrar o poder. ${ }^{, 38}$ Referido processo implicou a criação de um corpo de funcionários, oriundo da Igreja e das universidades, que contribuiu decisivamente para, sob a influência de um direito imperial romano e do direito eclesiástico, moldar os nascentes Estados sob a "imagem de uma monarquia absoluta e administrativizada., 39

A justiça penal real solapou, assim, as justiças senhoriais. Em substituição à atuação das partes e à resolução dos conflitos mediante a aplicação do direito local (por composições, e, em alguns casos, por curiosas ordálias e juízos de Deus), passou-se a verificar a atuação de uma burocracia real jurisdicional, sendo que a solução dos conflitos se dava através da aplicação do direito ditado pelo próprio Rei, que cunhou um processo penal estatal de matiz romano-canônica, o qual já era aplicado no âmbito eclesiástico e que serviria para consolidar o doravante denominado sistema processual inquisitorial. ${ }^{40}$

\footnotetext{
${ }^{36}$ Cf. análise mais aprofundada de ALMEIDA JÚNIOR, João Mendes de. O processo criminal brasileiro. 3. ed. augmentada. Rio de Janeiro: Typ. Baptista de Souza, 1920. v. 1, p. 94-115.

37 "A prática punitiva foi, talvez, a mais importante para permitir a substituição dos exercícios de 'justiças' e 'poderes' locais". (ANITUA, Gabriel Ignacio. Histórias dos pensamentos criminológicos. Tradução de Sérgio Lamarão. Rio de Janeiro: Revan, 2008. (Coleção pensamento criminológico, 15), p. 38).

${ }^{38}$ ANITUA, Gabriel Ignacio. Histórias dos pensamentos criminológicos. Tradução de Sérgio Lamarão. Rio de Janeiro: Revan, 2008. (Coleção pensamento criminológico, 15), p. 39.

${ }^{39}$ ANITUA, Gabriel Ignacio. Histórias dos pensamentos criminológicos. Tradução de Sérgio Lamarão. Rio de Janeiro: Revan, 2008. (Coleção pensamento criminológico, 15), p. 40.

${ }^{40}$ Como forma de centralizar o poder, os monarcas europeus empenharam-se em substituir aquele antigo direito local, baseado primordialmente em costumes, por um direito que realçasse a autoridade real, no que editaram uma crescente legislação com vigência em todo o território de seus respectivos reinos. Essa legislação nacional era inspirada no denominado direito comum, que resultava do renascimento do direito romano, de caráter imperial, e da renovação do direito canônico, que já demonstrava acentuadas feições inquisitoriais, o que reforçava as pretensões de poder dos monarcas. Cumpre registrar, em relação ao processo eclesiástico, que este se regia, a princípio, sob o signo do contraditório, no que se assemelhava ao processo penal laico da época. Contudo, a necessidade de se uniformizar a fé cristã e de se extirparem heresias, como a dos albigenses, fortalecendo-se, por consequência, o poder papal, suscitou o aparecimento de um sistema inquisitório no âmbito da Igreja, derivando daí a instituição da Inquisição. O processo penal influenciado por esse direito comum, notadamente, pelos cânones da Igreja, que passou a ser incorporado no ordenamento jurídico dos Estados nacionais, constituiu o sistema inquisitório histórico, cujas características são referidas pela literatura jurídica como: concentração das funções acusatória e julgadora em uma só pessoa ou órgão, ausência de isonomia processual entre as partes, forma escrita, ausência de contraditório, sigilo etc.
} 
Toda essa transformação política redundou em uma nova concepção sobre a conduta socialmente desviada. A ideia de dano, de repercussão privada, antes vigente, por força da política monárquica, restou substituída pela ideia de infração. ${ }^{41}$

A ofensa dirigia-se, dessarte, não à vítima (ou, ao menos, não em primeiro plano), mas sim ao Estado. O desvio social - a infração - representava, pois, um ato de desafio ao Rei e a seu Direito. E, como tal, merecia uma resposta à altura, resposta deliberadamente desproporcional, que fizesse despertar nos súditos a certeza de sua inferioridade em face da supremacia do poder de seu Monarca.

O sistema repressivo monárquico, sob tal perfil, substituiu a outrora vingança privada, por uma verdadeira vingança pública, em que os excessivos e desumanos castigos públicos infligidos aos criminosos ganhavam ares de um teatro carregado de verdadeiro simbolismo político. ${ }^{42}$ Sob tal ótica, o Estado, pelo Rei, vinga-se contra o infrator que ousou desafiar-lhe.

Nesse contexto histórico-político, dá-se uma verdadeira expropriação do conflito penal pelo Estado ou, na marcante expressão de NIELS CHRISTIE, o roubo do conflito por este. ${ }^{43}$ A relação que se dava outrora entre autor do desvio social e vítima passou a travar-se então entre aquele e o Estado, personificado pelo Rei. O conflito penal real cede espaço a um conflito penal artificial e despersonalizado, em que não há mais espaço para a vítima penal. ${ }^{44}$ Abre-se ensejo para a solução estritamente técnica desse conflito jurídico-artificializado, olvidando-se a solução do caso penal real. ${ }^{45}$

\footnotetext{
41 'Em primeiro lugar, apareceu a 'infração' em substituição ao 'dano'. Seria efetivada, dessa forma, a suposição de que o Estado é o lesado pela ação de um indivíduo pelo outro. E, portanto, seria o Estado quem exigiria a reparação. Foi por isso que surgiram, com ela, tanto a noção de 'delito', quanto a de 'castigo'." (ANITUA, Gabriel Ignacio. Histórias dos pensamentos criminológicos. Tradução de Sérgio Lamarão. Rio de Janeiro: Revan, 2008. (Coleção pensamento criminológico, 15), p. 43).

42 “O suplício tem então uma função jurídico-politica. É um cerimonial para reconstituir a soberania lesada por um instante. A execução pública, por rápida e cotidiana que seja, se insere em toda a série dos grandes rituais do poder eclipsado e restaurado (coroação, entrada do rei numa cidade conquistada, submissão dos súditos revoltados): por cima do crime que desprezou o soberano, ela exibe aos olhos de todos uma força invencível. Sua finalidade é menos de estabelecer um equilíbrio que de fazer funcionar, até um extremo, a dissimetria entre o súdito que ousou violar e o soberano todo-poderoso que faz valer sua força. [...]. E esta superioridade não é simplesmente a do direito, mas a da força física do soberano que se abate sobre o corpo de seu adversário e o domina: atacando a lei, o infrator lesa a própria pessoa do príncipe: ela - ou pelo menos aqueles a quem ele delegou sua força - se apodera do corpo do condenado para mostrá-lo marcado, vencido, quebrado.’(FOUCAULT, Michel, Vigiar e punir. Tradução de: Raquel Ramalhete, 25. ed. Petrópolis: Editora Vozes, 2009, p. 49).

${ }^{43}$ Cf. CÂMARA, Guilherme Costa. Programa de política criminal orientado para a vítima do crime. São Paulo: Editora Revista dos Tribunais; Coimbra: Coimbra Editora, 2008, p. 48.

${ }^{44}$ Sob o prisma processual, a vítima limita-se a exercer o papel de denunciante (autora da notitia criminis) ou de objeto de prova (testemunha).

45 “O progressivo processo de alienação da vítima do drama penal encontra-se de conseguinte fortemente conexionado à gradativa expropriação do conflito pelo Estado, que encontrou sua mais acabada fórmula na construção doutrinária do dano social. É que, como acabamos de verificar, as ofensas individuais passaram a
} 
O Século das Luzes (século XVIII) veio a presenciar o aparecimento de diversos expoentes de um iluminismo penal, atribuindo-se seu capitaneamento a BECCARIA, autor de Dos Delitos e das Penas (Dei Delitti e delle Pene, no original italiano), obra lançada em 1764, que, não obstante o anátema eclesiástico e sua rejeição acadêmica, tornou-se uma verdadeira bíblia da ilustração penal. ${ }^{46}$

Defendendo limitações palpáveis ao poderio estatal, que se expressavam na necessidade de previsão legal dos crimes e das penas, proporcionalidade e humanização destas, dentre outros princípios penais, BECCARIA, buscava fundamentos utilitaristas para a pena, ${ }^{47}$ tema comum aos penalistas ilustrados.

Por força da ideologia liberal-reformadora de então, estabeleceram-se as bases de um Direito Penal sistematizado, ${ }^{48}$ fulcrado em um conceito de legalidade estrita. ${ }^{49} \mathrm{~A}$

ser consideradas primeiro como ataques ao soberano e, posteriormente, de modo expansivo e quase indiscriminado, como ataques à comunidade. Qual a consequência desta nova concepção político-criminal, pergunta-se. Responde-se: a aplicação da pena, na verdade a própria finalidade do Direito penal, assumiu um caráter acentuadamente preventivo geral e especial, perdendo conteúdo reparatório. Deveras, tal neutralização da vítima progrediu até o ponto de poder descrever-se o conflito que está na base do fato penal com total prescindência da figura do sujeito concretamente lesionado, sendo de mister reconhecer, com HASSEMER e MUÑOZ CONDE, que 'o atual Direito penal, é dizer, o Direito penal do Estado já não é diferentemente do Direito penal primitivo, uma relação entre delinquente e vítima. Atualmente a vítima está neutralizada e em lugar da composição e do acordo entre o agressor e o agravado comparece a ação penal pública" (CÂMARA, Guilherme Costa. Programa de política criminal orientado para a vítima do crime. São Paulo: Editora Revista dos Tribunais; Coimbra: Coimbra Editora, 2008, p. 46-47).

${ }^{46}$ Sobre a obra, comenta ANITUA: "Os técnicos da época - como os de agora - escondiam sua covardia em um saber técnico vaidoso e inútil, e por isso a obra de Beccaria não foi a de um universitário nem teve repercussão nas casas em que o saber era, então, produzido. Os juristas das universidades e das magistraturas rechaçaram o livro. Consideraram-no perigoso e revolucionário, sujeito ao pecado do 'socialismo', pelo que não tardaram em cooperar com a condenação que a Igreja Católica lhe impôs, colocando-o no 'Índice' de proibição inquisitorial, no qual foi mantido por cerca de 200 anos, e nas tentativas de processar o autor, então protegido pelo poder estatal." (ANITUA, Gabriel Ignacio. Histórias dos pensamentos criminológicos. Tradução de Sérgio Lamarão. Rio de Janeiro: Revan, 2008. (Coleção pensamento criminológico, 15), p. 160161).

47 “Da simples consideração das verdades até aqui expostas é evidente que o fim das penas não é o de atormentar e afligir um ser sensível, nem de desfazer um delito já cometido. Pode ele, em um corpo que, bem longe de agir por paixão, é o tranquilo moderador das paixões particulares, pode ele albergar esta inútil crueldade, instrumento do furor e do fanatismo ou dos fracos tiranos? Os gritos estridentes de um infeliz talvez reclame, do tempo que não retorna, as ações já consumadas? O fim, portanto, não é outro que o de impedir que o réu cometa novos danos aos seus cidadãos e de demover os outros de fazerem o mesmo. Aquelas penas, portanto, e aquele método de infligi-las deve ser eleito de tal forma que, observada a proporção, causará uma impressão mais eficaz e mais durável sobre os ânimos dos homens, e a menos tormentosa sobre o corpo do réu." (BECCARIA, Cesare. Dos delitos e das penas. São Paulo: Quartier Latin, 2005, p. 57).

48 "Eduardo Correia refere-se ao direito, que vigorava antes do iluminismo, como 'grosseiro, casuístico e arbitrário, pois nenhuma construção geral do delito existia; dominado por uma ideia de intimidação brutal, com penas extraordinariamente cruéis (açoites, marcas, mutilações, mortes por suplícios) e acompanhadas de sofrimentos morais (como a exposição no pelourinho à irrisão pública)' [...]”' (FERNANDES, Giovana Polo. A vítima do crime no processo penal. Revista da Procuradoria Geral do Estado de São Paulo, São Paulo, 59/60, p. 221-240, jan./dez. 2004, p. 223).

49 "Com efeito, os iluministas não reclamavam qualquer tipo de legalidade. Nem todo Estado que tem leis ou é baseado em uma mera legalidade é um Estado de direito. O que aparece, sim, como uma reivindicação ilustrada, é o que Ferrajoli chama de 'legalidade estrita' [...] Este outro tipo de legalidade é o que deveria 
evolução humanizadora de então, que se estenderia pelos séculos seguintes, orientou-se, todavia, unilateralmente, ocupando-se exclusivamente dos direitos e garantias da pessoa acusada do delito, prosseguindo sua vítima no mais completo olvidamento provocado em razão da expropriação estatal do conflito penal.

\subsubsection{Redescoberta ou movimento vitimológico}

O contexto histórico seguinte às guerras mundiais travadas na primeira metade do século XX presenciou o início de um volver generalizado dos olhares para os direitos humanos, extensível à situação das vítimas em geral, o que ensejou a deflagração de uma nova fase, a fase de redescoberta da vítima, também denominada de movimento vitimológico. $^{50}$

Cumpre realçar que o início desse movimento não pode ser atribuído a nenhum fator histórico isolado, mas a uma conjunção de fatores, dos quais CÂMARA aponta a macrovitimização decorrente do holocausto ${ }^{51}$ e o aumento da criminalidade verificável nos grandes centros urbanos, ${ }^{52}$ ao que BAAMONDE acrescenta a constante ameaça de uma guerra nuclear em grande escala, ${ }^{53}$ fator este que melhor pode ser considerado à vista do conceito de sociedade do risco,${ }^{54}$ cunhado por BECK.

definir os delitos nas novas ordens propugnadas. Esta outra legalidade é a que Beccaria reclamava quando dizia que 'só as leis podem decretar as penas dos delitos e esta autoridade deve residir no legislador." Este limite, assinalado como nulla poena, nullum crimen sine lege, abrange toda a política criminal, quer no momento de criação do delito e da pena - garantia criminal e penal-, que no momento de sua aplicação a um caso concreto, pelo juiz ordinário determinado pela lei prévia - garantia jurisdicional - e, em seu caso, antes a execução da pena - garantia de execução". (ANITUA, Gabriel Ignacio. Histórias dos pensamentos criminológicos. Tradução de Sérgio Lamarão. Rio de Janeiro: Revan, 2008. (Coleção pensamento criminológico, 15), p. 189).

${ }^{50} \mathrm{O}$ termo redescoberta da vítima parece sugerir um mero retorno à fase do protagonismo da vítima, tal qual se passava na idade de ouro desta, sentido esse que se tenta afastar, no que se utiliza também a expressão movimento vitimológico.

${ }^{51} \mathrm{O}$ termo holocausto não tem encontrado uma aceitação unânime, principalmente no meio judaico, tendo em vista denotar um sacrifício religioso, de caráter voluntário, no que levariam vantagem termos como o churban (destruição) ou, preferencialmente, shoah (catástrofe) Cf: DANZIGER, Leila. Shoah ou holocausto - a aporia dos nomes. Disponível em: <http://leiladanziger.com/text/32shoah.pdf>. Acesso em: 09 fev. 2011.

${ }^{52}$ Cf. CÂMARA, Guilherme Costa. Programa de política criminal orientado para a vítima do crime. São Paulo: Editora Revista dos Tribunais; Coimbra: Coimbra Editora, 2008, p. 65-66.

${ }^{53}$ BAAMONDE. Xulio Ferreiro. La víctima en el proceso penal. Madrid: La Ley, 2005, p.32.

54 “Atualmente vivemos em uma sociedade do risco, na qual a vitimização pode operar-se em macro escala. Vale gizar, que a expressão sociedade do risco introduz a idéia de superação de uma etapa da caminhada humana em que os riscos apresentavam-se de uma forma algo limitada, vez que descendiam de condutas humanas de resultados mais ou menos previsíveis, para um estágio civilizatório que se faz notável pela imprognosticabilidade da exata dimensão e extensão dos riscos e que revela, de um lado, uma 'fratura dentro 
Nas décadas de 70 e 80, o despertar vitimológico ganhou maior fôlego, em grande parte devido ao desenvolvimento de uma nova ciência, cujo objeto de estudo centra-se na pessoa da vítima: a Vitimologia, cuja importância para o movimento vitimológico nos leva a tercer-lhe, nesta oportunidade, alguns comentários gerais.

A rigor, não se pode atribuir à Vitimologia o pioneirismo no que concerne à abordagem sobre as vítimas. Importa registrar, nesse ponto, que, conforme recorda MANZANERA, em referência a STANCIU, "hay que evitar el error de creer que nosotros somos los primeros en estudiar la Victimología. Si el término Victimología es nuevo, el objeto es antiguo." 55

De fato, referências à vítima, ou mesmo o fato de constituir essa um objeto de estudo, não são exclusividade do século XX. Legislações da Antiguidade, conforme visto, já estabeleciam disciplinamento acerca da vítima, como o prova a Lei do Talião. O positivismo criminológico, do século XIX, pelas letras de LOMBROSO, FERRI ${ }^{56}$ e GAROFALO, já manifestava acentuada preocupação em relação às vítimas de delito, ensejando o tratamento ao tema em diversos congressos internacionais, ${ }^{57}$ muito embora a Escola Positivista, segundo MOLINA, utilizasse de tal argumento com o propósito de limitar os direitos do autor do delito. ${ }^{58}$

da modernidade'; de outro, a notável complexidade da sociedade pós-moderna. Mas, e que não é lícito ignorar, no passado os riscos não estavam confinados à ação do homem, vez que existia uma outra esfera de riscos (até hoje ainda não superados por completo) que emanavam da própria imponderabilidade das forças da natureza. A idéia de sociedade do risco conduz-nos, assim, a um mundo em que os riscos naturais apresentam-se cada vez mais previsíveis e controláveis, e por isso mesmo passíveis de serem reduzidas as possibilidades de concretização do perigo; de outro lado, revela-nos uma catadupa de novos riscos, de inusitada dimensão, riscos incomensuráveis derivados da tecno-ciência, com aptidão para gerarem verdadeiras 'enfermidades civilizatórias', ameaçando o futuro da humanidade". (CÂMARA, Guilherme Costa. Programa de política criminal orientado para a vítima do crime. São Paulo: Editora Revista dos Tribunais; Coimbra: Coimbra Editora, 2008, p. 129-130).

${ }^{55}$ MANZANERA, Luis Rodriguez. Victimología. 12. ed. Cidade do México: Porrúa, 2010, p. 6.

56 “[...] a Escola Positivista, desde os seus primórdios, pôs em grande relevo a condição jurídico-social da parte lesada ou vítima do crime e a obrigação, além da conveniência social, de lhe tutelar mais eficazmente os direitos e interesses. Na minha segunda preleção (nov. 1881) na Universidade de Bolonha, eu sustentei precisamente que os protagonistas na justiça penal, em vez de dois, são três, pois que, além do réu (sujeito ativo) e do Ministério Público, há a parte ofendida (sujeito passivo) - pelo que concluí que a indenização do dano produzido pelo crime não é relação de direito privado (como, por exemplo, a proveniente do não cumprimento de um contrato), mas sim de direito público, porquanto provém 'ex delicto', que é ação contrária ao direito penal e, por isso, público. Portanto, deve ser função do Estado da mesma forma que o é a inflação da pena. Garofalo, que, nessa altura, era procurador substituto do Rei em Bolonha, acolheu e desenvolveu as minhas idéias, acrescentando que a indenização do dano poderá substituir 'as penas carcerárias de curta duração nos pequenos delitos cometidos por delinquentes ocasionais'. E desde então, as ideias e as propostas da Escola Positiva têm sido discutidas na doutrina e nos congressos (do I internac. de Antrop. Crim., Roma, 1885, com a ordem do dia Ferri - Fioretti - Venezian, aos diversos congressos da 'União intern. de dir. Pen.', e até nos congressos penitenciários), conquistando sempre cada vez mais o consenso geral'". (FERRI, Enrico. Princípios de direito criminal. Tradução de Paolo Capitanio. $2^{\mathrm{a}}$ ed. Campinas: Bookseller, 1999).

${ }_{57}^{57}$ MANZANERA, Luis Rodriguez. Victimología. 12. ed. Cidade do México: Porrúa, 2010, p. 9.

58 MOLINA, Antonio Garcia-Pablos de. Criminologia: uma introdução a seus fundamentos teóricos. Tradução de Luiz Flávio Gomes. São Paulo: Revista dos Tribunais, 1992, p. 45. 
Todavia, uma abordagem mais sistematizada sobre a vítima somente ganha espaço a partir da Vitimologia. Os créditos pela criação de tal disciplina são atribuídos a dois pesquisadores: BENJAMIN MENDELSOHN e HANS VON HENTIG. Para MANZANERA, o primeiro estudo sistemático sobre as vítimas deve ser atribuído a MENDELSOHN, que se ocuparia do tema desde 1937, publicando suas primeiras obras em 1940 (Giustiza Penale), seguindo-se as publicações de 1946 (New bio-psycho-social horizons: victimology) e 1956 (La Victimologie), ao passo que HENTIG somente publicaria a sua obra The criminal and his victim, em $1948 .{ }^{59}$

Os estudos iniciais vitimológicos tiveram por objeto temas relacionados ao papel da vítima na gênese do delito, a denominada vitimodogmática ${ }^{60}$ - ensejando tipologias de vítimas ${ }^{61}$ - e o estudo da relação entre vítima e ofensor (dupla penal).

Mencionada abordagem, porém, longe de reconhecer a importância da vítima no conflito penal e de assegurar seus direitos, ensejava uma verdadeira imagem culpabilizadora daquela, ${ }^{62}$ razão pela qual - no que contribuiu decisivamente o movimento feminista norte-americano ${ }^{63}$ - passou-se a atentar para um enfoque mais adstrito aos direitos das vítimas e a suas necessidades mais concretas.

\footnotetext{
${ }^{59}$ MANZANERA, Luis Rodriguez. Victimología. 12. ed. Cidade do México: Porrúa, 2010, p. 9-10. Como outros expoentes, nesses primeiros momentos, podem ser também citados WERTHAM e ELLENBERGER. (MANZANERA, Luis Rodriguez. Victimología. 12. ed. Cidade do México: Porrúa, 2010, p. 10).

${ }^{60}$ Para OLIVEIRA, "Pôr em relevo todas as nuanças do Direito Penal, em que a conduta da vítima tem específica significação, abriu espaço para a moderna construção da Vitimodogmática. Estabelecer, então, a maior ou menor contribuição da vítima no processo de configuração do crime, com destaque à valoração dogmática do comportamento vitimal, insere-se no eixo da Vitimodogmática. (Cancio Meliá, 1998, p. 23)." (destaques do autor). (OLIVEIRA, Edmundo. Vitimologia e direito penal: o crime precipitado pela vítima. 4. ed. Rio de Janeiro: Forense, 2005, p. 32-33).

${ }^{61}$ Interessante a tipologia formulada por MENDELSOHN, que classifica as vítimas sob a graduação de sua culpa, conforme a seguinte escala: vítima completamente inocente, vítima de culpabilidade menor ou por ignorância, vítima voluntária ou tão culpada quanto o infrator, vítima mais culpada que o infrator e, por fim, vítima unicamente culpada: Ibid., p. 194-195.

${ }^{62}$ Embora essa abordagem se revista de tal viés, MOLINA consegue discernir, no alvorecer dos estudos da Vitimologia, a percepção de uma nova perspectiva da vítima: "Os primitivos estudos vitimológicos se circunscreveram aos protagonistas principais do fato criminoso e pretendiam demonstrar a interação existente entre autor e vítima. De fato, um dos méritos das tipologias que seus pioneiros elaboraram (von Hentig, Mendelsohn etc.) foi o de salientar uma nova imagem muito mais realista e dinâmica da vítima, como sujeito ativo - e não como mero objeto - capaz de influir significativamente no próprio fato delitivo, em sua estrutura dinâmica e prevenção.” (destaque do autor). (MOLINA, Antonio Garcia-Pablos de. Criminologia: uma introdução a seus fundamentos teóricos. Tradução de Luiz Flávio Gomes. São Paulo: Revista dos Tribunais, 1992, p. 45-46).

63 “A convulsionada década de sessenta também foi palco de um 'movimento feminista' ativista e radical (particularmente nos Estados Unidos), capaz de mobilizar diversos segmentos sociais com o intuito de exigir providências enérgicas voltadas a combater atos de violência cometidos contra as mulheres. Além de pleitear mudanças legislativas direcionadas ao 'agravamento das penas' dos crimes relacionados à violência sexual, não pouparam críticas ácidas à criminologia (vitimologia) tradicional, responsável pela construção de tipologias, em que a vítima aparece como culpada, provocadora, precipitadora, e que funcionam como fortes componentes de revitimização. VIANO assinala que nos Estados Unidos o 'movimento' em prol das vítimas teve por força primária a agitação feminista que, de sua vez, inspirava-se no 'civil rights movement'."
} 
A Vitimologia, indiscutivelmente, tem a vítima por objeto de estudo. Esse postulado, aparentemente simples, pode levar a considerações mais complexas, a depender das diversas interpretações que podem ser conferidas ao termo vítima.

Assim, surgem indagações, tal como a de quem (ou o quê) pode ser considerado vítima, bem como - considerando que a Vitimologia germinou a partir da Criminologia - o questionamento acerca de qual tipo de vítima se ocupa tal disciplina: tãosomente a vítima de infração penal ou a vítima em uma concepção mais ampla.

Essas considerações acerca do termo vítima se mostram imprescindíveis para se tratar a questão da autonomia científica da Vitimologia em relação à Criminologia.

Para MENDELSOHN, cuja concepção ampla compreende as vítimas não penais, inclusive a vítima de si mesmo, a Vitimologia deveria ter sua autonomia reconhecida em relação à Criminologia, o que ensejou a forte oposição de MANHEIM, segundo o qual a retirada da Criminologia do enfoque à vítima confinaria esta ao estudo do delinquente, perdendo-se outros relevantes aspectos referentes ao crime, ${ }^{64}$ fomentando-se um debate que parece encontrar-se longe de uma conclusão definitiva. ${ }^{65}$

Sobre tal questão, também se ocupa MANZANERA. Para o autor mexicano, "los enfoques dependen en mucho de cómo se defina a la víctima, lo que está muy ligado a la orientación ideológica e filosófica del investigador." Dito autor parte da distinção entre três diferentes paradigmas e suas correspondentes tendências (ideologias) e modelos (perspectivas): a) positivista-conservadora-consensual; b) interacionista-liberal-pluralista; c) crítica-socialista-conflitual, ${ }^{66}$ e termina por concluir pela existência de uma Vitimologia Geral e de uma Vitimologia Criminológica. ${ }^{67}$

(CÂMARA, Guilherme Costa. Programa de política criminal orientado para a vítima do crime. São Paulo: Editora Revista dos Tribunais; Coimbra: Coimbra Editora, 2008, p. 88).

${ }^{64}$ (CÂMARA, Guilherme Costa. Programa de política criminal orientado para a vítima do crime. São Paulo: Editora Revista dos Tribunais; Coimbra: Coimbra Editora, 2008, p. 72).

65 CÂMARA refere-se ao pensamento de ELIAS NEUMAN nos seguintes termos: "entendendo que atualmente de acordo com a imensa maioria dos autores e investigadores pode considerar-se a vitimologia como um ramo da criminologia, mas que uma vez ampliado o seu raio de operatividade a todas as vítimas sociais '[...] haverá de rever-se e reformular tal conceito', concluindo no sentido de que 'O tempo dirá se a vitimologia se constituirá no futuro em uma ciência que se encarregue de toda a classe de vítimas (sociais e penais)"'. (CÂMARA, Guilherme Costa. Programa de política criminal orientado para a vítima do crime. São Paulo: Editora Revista dos Tribunais; Coimbra: Coimbra Editora, 2008, p. 73).

${ }_{66}$ MANZANERA, Luis Rodriguez. Victimología. 12. ed. Cidade do México: Porrúa, 2010, p. $26-29$.

67 "Aunque pudiere parecer paradoja, nosotros concedemos en toda su amplitud la autonomia a la Victimología, y a la vez aceptamos sua pertenencia a la Criminología . [...]. En cuanto logra identificar un objeto próprio y reunir las características requeridas para toda ciencia fáctica, la Victimología adquiere su autonomía cientifica. Por outra parte, cuncurre a formar la gran síntesis crimimológica; que no se puede concebir, sin análisis de las víctimas. Nadie negaría que la Biología, la Antropología, la Psicología o la Sociología tienen total autonomia cientifica, y que su objeto de estudio supera en mucho al fenómeno antisocial. Nadie duda ya que estas ciencias vienen a conformar la síntesis criminológica, creando un conjunto de conocimientos nuevos, diversos de su objeto original. Algo semejante sucede com la 
O desenvolvimento da Vitimologia se deu mediante toda uma mobilização acadêmica e científica em torno das vítimas.

Nesse ponto, cabe registrar os diversos simpósios internacionais vitimológicos que ocorrem desde a década de 70, em diversas cidades do mundo: Jerusalém (Israel) 1973; Boston (EUA) - 1976; Münster (Alemanha) - 1979 (onde se formou a World Society of Victmology (WSV), que passou a organizar os eventos seguintes); Tóquio/Kyoto (Japão) - 1982; Zagreb (Iugoslávia) - 1985; Jerusalém (Israel) - 1988; Rio de Janeiro (Brasil) 1991; Adelaide (Austrália) - 1994; Amsterdã (Holanda) - 1997; Montreal (Canadá) 2000; Stellenbosch (África do Sul) - 2003; Orlando (EUA) - 2006; Mito (Japão) - 2009; Haia (Holanda) - 2012.

$\mathrm{Na}$ esteira do movimento vitimológico e do desenvolvimento da Vitimologia, importantes documentos internacionais e diplomas legais vieram à lume. A Organização das Nações Unidas (ONU) passou a demonstrar interesse pelo tema e, em 1980, durante o VI Congresso Sobre a Prevenção ao Crime e Tratamento de Infratores, em Caracas (Venezuela), despertou-se para a necessidade de se elaborar uma declaração que versasse sobre os direitos das vítimas.

Já em 1982, durante o VI Simpósio Internacional da WSV, no Japão, foi constituída uma Comissão, a qual, em 1983, durante o IX Congresso Internacional de Criminologia, em Viena (Áustria), apresentou o projeto inicial do texto que seria aprovado, em 1985, na Assembleia da ONU, como a Declaração dos Princípios Básicos de Justiça Relativos às Vítimas da Criminalidade e de Abuso de Poder (Resolução 40/34, de 29.11.1985), seguindo-se diversos outros documentos complementares, como a Resolução 1989/57, do Conselho Econômico e Social (Aplicação da Declaração dos Princípios Básicos de Justiça Relativos às Vítimas da Criminalidade e de Abuso de Poder), a Resolução 1990/22, do Conselho Econômico e Social (Vítimas de Criminalidade e de Abuso de Poder), a Resolução do $8^{\circ}$ Congresso das Nações Unidas para Prevenção do Crime e Tratamento dos Delinquentes, realizado de 27 de agosto a 7 de setembro de

Victimología; su objeto de estudio es más amplio que el fenómeno criminal y la relación criminal-víctima, por lo que puede manejarse en forma indepediente; por outra parte, concurre con las outras ciencias criminológicas a conformar la síntesis que es la esencia de la Criminología. [...]. El problema es, por lo tanto, aparente. La solución puede encontrarse en el reconocimiento de una Victimología General (como de una Psicología, Sociología o Biología Generales), que estudia a todas las víctimas, y de una Victimología Criminológica, concurrente a la sintesis criminológica y encargada de estudiar a las víctimas de condutas antisociales." (MANZANERA, Luis Rodriguez. Victimología. 12. ed. Cidade do México: Porrúa, 2010, p. 31-32). 
$1990 .^{68}$

No âmbito europeu, desde o final da década de 1970, editam-se seguidas normas que tratam sobre os direitos das vítimas de delito. Assim, o Conselho da Europa editou a Resolução (77)27, de 28.09.1977 (indenização às vítimas de infrações criminais), a Convenção Europeia Relativa à Indenização de Vítimas de Infrações Violentas, em 24.11.1983, a Recomendação R (85)11, de 28.06.1985 (posição da vítima no ordenamento penal e processual penal), a Recomendação R (87)21, de 17.09.1987 (assistência às vítimas de crime e prevenção da vitimação), dentre outras normas.

De edição mais recente, destacam-se a Decisão-quadro do Conselho da União Europeia Relativo ao Estatuto da Vítima em Processo Penal, de 15.03.2001, e a Diretiva Relativa à Indenização das Vítimas de Criminalidade (Diretiva 2004/80/CE), de 29.04.2004.

Importante registrar ainda, que no ano de 1990, diversas organizações nacionais europeias de apoio a vítimas da criminalidade fundaram o European Forum for Victim Services, cujo nome posteriormente foi modificado para Victim Support Europe, ${ }^{69}$ que constitui hoje uma rede de mais de vinte organizações presentes no continente europeu, que tem editado importantes e valiosas declarações de princípios a favor das vítimas, como a referente aos direitos da vítima no processo penal, a concernente aos direitos sociais da vítima de crime e o estatuto da vítima no processo de mediação. ${ }^{70}$

Nas Américas, embora não haja um documento específico sobre tal tema em âmbito continental, os arts. $8^{\circ}$ (alínea 1) e 25, da Convenção Americana de Direitos Humanos, são interpretados em favor das vítimas pela Corte Interamericana de Direitos Humanos. $^{71}$

\footnotetext{
${ }^{68}$ Em 2006, por ocasião da UN Convention on Justice and Support for Victims of Crime and Abuse of Power, elaborou-se um rascunho de um código de direitos para as vítimas, a fim de viabilizar uma aplicação integral da Resolução 40/34, de 29.11.1985: UN Convention on Justice and Support for Victims of Crime and Abuse of. Disponível em: <http://www.apav.pt/portal/pdf/convention.pdf>. Acesso em: 14 set. 2011.

${ }^{69}$ Em Portugal, por exemplo, a organização filiada à Victim Support Europe é a Associação Portuguesa de Apoio à Vítima (APAV).

${ }^{70}$ Victim Support Europe. Disponível em: <http://www.victimsupporteurope.eu/>. Acesso em: 14 set. 2011.

${ }^{71}$ LANZÓN, Román P. La intervención de la víctima en el proceso penal y su derecho a actuar como querellante. In: GUZMÁN, Nicolás. (Coord.). El sistema penal en las sentencias recientes de los órganos interamericanos de protección de los derechos humanos. Buenos Aires: Ad Hoc, 2009, p. 223-250; 245246. Eis os dispositivos da Convenção citados: "Art. 8.1. Toda pessoa tem direito a ser ouvida, com as devidas garantias e dentro de um prazo razoável, por um juiz ou tribunal competente, independente e imparcial, estabelecido anteriormente por lei, na apuração de qualquer acusação penal formulada contra ela, ou para que se determinem seus direitos ou obrigações de natureza civil, trabalhista, fiscal ou de qualquer outra natureza; Art. 25. Toda pessoa tem direito a um recurso simples e rápido ou a qualquer outro recurso efetivo, perante os juízes ou tribunais competentes, que a proteja contra atos que violem seus direitos fundamentais reconhecidos pela constituição, pela lei ou pela presente Convenção, mesmo quando tal violação seja cometida por pessoas que estejam atuando no exercício de suas funções oficiais".
} 
A par das normas oriundas de organismos internacionais, o movimento vitimológico ensejou uma verdadeira proliferação de leis nacionais versando sobre a vítima e seus direitos, verificável em todo o mundo ocidental. Pode-se citar a Alemanha como exemplo paradigmático, cuja legislação sobre o tema influenciou e continua influenciando todo o continente europeu e demais países ocidentais.

Já em 1976, os alemães promulgaram a Lei de Reparação das Vítimas de Crimes Violentos - Opferentschädigungsgesetz - Gesetz über die Entschädigung für Opfer von Gewalttaten, seguindo-se leis como a Lei de Proteção da Vítima do Crime, de 1986, a Lei para a Proteção de Testemunhas e para a Melhora da Proteção da Vítima, de 1998, e a Lei para a Melhora dos Direitos dos Ofendidos no Processo Penal, de 2004.

Interessante observar também quanto ao movimento vitimológico que, sob o viés criminológico, não se pode falar de uma única força motriz ideológica a sustentar esse movimento, o que deve merecer especial consideração por quem se ocupa de tal fenômeno.

De fato, a cada vez mais crescente preocupação com as vítimas apoia-se em pensamentos criminológicos diversos e mesmo, o que não deixa de ser curioso, antagônicos. Dentre tais pensamentos, de um lado, pode-se indicar a ideologia presente no movimento político-criminal Law and $O r d e r,{ }^{72}$ que se serve de motes vitimológicos a fim de despertar um sentimento de empatia, granjeando, assim, adeptos a seu ideal de Estado Penal máximo e Estado Social mínimo. ${ }^{73}$ Como fator ideológico contraposto, podem ser

\footnotetext{
${ }^{72}$ MAZZILLI NETO se refere a movimentos de Lei em Ordem - no plural - definindo-lhes os caracteres nos seguintes termos: 'Cumpre, inicialmente, esclarecer que, embora enunciados no plural, os 'movimentos' a que nos referimos devem ser entendidos - e podem ser estudados - em sua unidade, que, em síntese, reside na 'ideologia da repressão, fulcrada no velho regime punitivo-retributivo, que recebe a que recebe, agora, o enganoso nome de Movimento de Lei e Ordem', conforme anotava Heleno Fragoso. Na verdade, esse movimento pode ser considerado um bloco sólido que, hoje, inspira e dá forma a muitos sistemas penais, sempre a partir de características comuns e que vem avançando de maneira consistente em muitos países latino-americanos, os quais se encontram (cada vez mais) sob a influência dos Estados Unidos da América, berço do Law and Order. Assim, com tênues variações os movimentos de Lei e Ordem se apresentam com coesão suficiente para serem analisados de forma global, com um único movimento de política criminal, com profundos reflexos na forma de operar no sistema penal. A 'força motriz' de tal movimento consiste em campanhas (aí sim, no plural) pelo aumento da repressão, do tipo 'tolerância zero' e outras similares, que têm como característica maior a maximização da intervenção do direito penal em todas as esferas da sociedade, não apenas como instrumento de controle social mas também como panacéia para a solução dos mais variados problemas, além de se transformar em plataforma política." (MAZZILLI NETO, Ranieri. Os caminhos do sistema penal. Rio de Janeiro: Revan, 2007, p. 19).

73 “Ademais, é certo que as diretrizes neoliberais, pregando a austeridade orçamentária e o fortalecimento dos direitos do capital, acompanhado da contenção dos gastos públicos e redução da cobertura social, necessitam englobar o tratamento punitivo como forma de conter a insegurança e a marginalidade: ao lado da mão invisível o mercado no âmbito econômico, há que se utilizar a mão-de-ferro do Estado no campo penal, para a contenção dos deserdados, excluídos indesejados, não consumidores. Assim. O modelo neoliberal expõe sua faceta numa equação que implica: a) a supressão do Estado econômico; b) o enfraquecimento do Estado Social; e c) o fortalecimento e glorificação do Estado penal: 'à atrofia deliberada do Estado social correspondente'. Em outros termos, ao Estado social mínimo, deve corresponder um Estado penal máximo, que dê respostas às desordens provocadas pela desregulamentação econômica, pela pulverização do trabalho
} 
mencionados os pensamentos criminológicos marxistas, rotulados sob a denominação de criminologia crítica - em especial, o realismo de esquerda ${ }^{74}$ e o abolicionismo ${ }^{75}$ - que se debruçariam sobre os problemas reais das vítimas concretas do delito. ${ }^{76}$

Por fim, dentre tantas outras consequências do movimento vitimológico, podese mencionar especialmente o desenvolvimento de uma extensa cadeia de política social em favor das vítimas, nunca antes vista, que se traduz em programas de assistência, reparação, compensação e tratamento.

Conforme MOLINA, esses programas apareceram desde a década de $60 \mathrm{em}$ países como a Nova Zelândia e o Reino Unido, destacando quatro programas distintos, a saber; a) programas de assistência imediata, geralmente financiados por instituições privadas, que cuidam de necessidades mais imperiosas, do tipo material, física, ou médica, geralmente, a vítimas específicas, como anciãos, mulheres violadas etc.; b) programas de reparação, pertencentes ao Poder Público, que objetivam viabilizar a reparação do dano pela vítima mediante o pagamento de uma quantia em dinheiro ou da realização de certa atividade ou serviço pelo infrator em benefício da vítima; c) programas de compensação à vítima: consistem em fundos públicos que beneficiam, em caráter monetário, as vítimas, sob forma de indenizações ou seguros; d) programas de assistência à vítima declarante: direcionados à vítima que se dispõe a prestar declarações ou testemunho no processo, beneficiando-se a própria vítima e o sistema judicial com tal cooperação. ${ }^{77}$

\subsection{REDESCOBRINDO A VÍTIMA NO PROCESSO PENAL BRASILEIRO}

assalariado e alarmante aumento da pobreza." (ROSA, Alexandre Morais da; SILVEIRA FILHO, Sylvio Lourenço da. Para um processo penal democrático: crítica à metástase do sistema de controle social. Rio de Janeiro: Lumen Juris, 2008, p. 26-27).

74 ANITUA, Gabriel Ignacio. Histórias dos pensamentos criminológicos. Tradução de Sérgio Lamarão. Rio de Janeiro: Revan, 2008. (Coleção pensamento criminológico, 15), p. 713-723.

${ }^{75}$ ANITUA, Gabriel Ignacio. Histórias dos pensamentos criminológicos. Tradução de Sérgio Lamarão. Rio de Janeiro: Revan, 2008. (Coleção pensamento criminológico, 15), p. 695-713.

76 "Na verdade, a criminologia crítica não promoveria, nesses últimos anos, apenas uma recuperação das vítimas. Esse fenômeno é totalmente generalizado e os pensamentos mais conservadores se apoiariam ficticiamente nas vítimas para aumentar o poder repressivo, alegando um cálculo de 'soma zero': quanto mais se proteja o vitimador, mais dano se faz à vítima e o reverso. A criminologia crítica enfocaria de outra maneira a questão e seriam, assim, provavelmente, os criminólogos críticos os que mais atenção prestariam às vítimas reais e às suas necessidades não punitivas, particularmente os realistas de esquerda e os abolicionistas, enquanto os garantistas ficariam presos a seu arsenal jurídico que é estranho às vítimas." (ANITUA, Gabriel Ignacio. Histórias dos pensamentos criminológicos. Tradução de Sérgio Lamarão. Rio de Janeiro: Revan, 2008. (Coleção pensamento criminológico, 15), p.752-753).

77 MOLINA, Antonio Garcia-Pablos de. Criminologia: uma introdução a seus fundamentos teóricos. Tradução de Luiz Flávio Gomes. São Paulo: Revista dos Tribunais, 1992, p. 60-65. 


\subsubsection{O conceito de vítima no âmbito do processo penal brasileiro}

Antes de tratar propriamente da redescoberta da vítima no âmbito do processo penal, impende que seja retomado o estudo iniciado quando da análise das primeiras aproximações conceituais sobre a vítima, ${ }^{78}$ ocasião em que se estabeleceu a necessidade de uma aproximação conceitual de caráter jurídico sobre a vítima, abandonando-se concepções alheias, presentes, por exemplo, na seara da Criminologia ou mesmo da Vitimologia.

A princípio, convém registrar as dificuldades advertidas por FERNANDES quanto à concepção jurídica da vítima.

A primeira dificuldade apontada pelo referido autor consiste na possibilidade de distinção de um conceito amplo e de um conceito estrito, a depender de se tratar de vítima penal ou não. Assim, sob uma ótica jurídica mais ampla, vítimas podem ser identificadas nas relações jurídicas civis, trabalhistas, comerciais etc., conceito esse mais amplo que o conceito da vítima penal; o conceito estrito, por outro lado, confunde-se com o próprio conceito de vítima penal, ou seja, da vítima da violação de uma norma jurídicopenal. $^{79}$

Como se vê, o conceito mais estrito parece mais de acordo com os fins deste trabalho. O problema é que - e aí está a segunda dificuldade apontada por FERNANDES a vítima pode desempenhar, no processo penal, uma variedade de papéis, que pode implicar uma variedade terminológica.

Assim, a vítima pode perseguir a justa aplicação de sanção penal ao acusado, o que se traduziria em interesse penal, ou mesmo perseguir a indenização referente ao dano decorrente da prática do ilícito penal, o que seria um interesse não penal. Daí o aludido autor afirmar que "quem defende interesses civis no processo criminal é prejudicado, lesado, danificado, parte civil, ofendido. Aquele que persegue interesse penal: querelante, sujeito passivo da infração criminal, ofendido." 80

O próprio Código de Processo Penal brasileiro (CPP) já apresenta grande

\footnotetext{
${ }^{78}$ Vide item 2.2.

${ }^{79}$ Para conferir análise completa do autor, cf. FERNANDES, Antônio Scarance. O papel da vítima no processo criminal. São Paulo: Malheiros, 1995, p.40-43.

${ }^{80}$ FERNANDES, Antônio Scarance. O papel da vítima no processo criminal. São Paulo: Malheiros, 1995, p. 42.
} 
variedade terminológica, no que se refere às vítimas, quer em seus dispositivos originais, de 1941, quer após os acréscimos de legislação posterior, não guardando uniformidade terminológica em relação à matéria.

Assim, o termo vítima pode ser encontrado, por exemplo: no art. 185, $\S 2^{\circ}$, inciso III, ${ }^{81}$ com redação dada pela Lei n ${ }^{\circ} 11.900$, de 08.01 .09 , e no art. $240,{ }^{82}$ que trata da busca e apreensão, ainda em sua redação original; percebe-se também o termo ofendido, utilizado na redação original de 1941, como no art. 302, inciso II, ${ }^{83}$ referente às hipóteses de prisão em flagrante, bem como em dispositivos de redação recente, como o art. 201, reformulado pela Lei $\mathrm{n}^{\circ} 11.690 / 2008$; pode-se ainda referir a expressão titular do direito à reparação do dano, que pode ser encontrada no art. $65,{ }^{84}$ bem como o termo lesado, presente no art. $119 ;{ }^{85}$ ainda se pode apontar também o termo assistente (art. 268 ss.) que designa a vítima investida processualmente, ou seja, habilitada nos autos da ação penal de iniciativa pública, e o termo querelante, que se emprega para designar o autor da ação penal de iniciativa privada, conforme se observa do art. $44 .^{86}$

Dessarte, no quadro terminológico em face do Código de Processo Penal podese identificar a vítima como vítima, ofendido ou mesmo titular do direito à reparação do dano ou lesado (nestes últimos dois casos quando se tem os interesses cíveis em perspectiva especial); caso a vítima se habilite nos autos em ação penal de iniciativa pública, passa a denominar-se assistente, e se a vítima ajuizar a ação penal de iniciativa privada obtém a denominação legal de querelante.

Dentro desse contexto terminológico, FERNANDES concebe a vítima, no

\footnotetext{
81 “Art. 185. O acusado que comparecer perante a autoridade judiciária, no curso do processo penal, será qualificado e interrogado na presença de seu defensor, constituído ou nomeado. $\S 2^{\circ}$ Excepcionalmente, o juiz, por decisão fundamentada, de ofício ou a requerimento das partes, poderá realizar o interrogatório do réu preso por sistema de videoconferência ou outro recurso tecnológico de transmissão de sons e imagens em tempo real, desde que a medida seja necessária para atender a uma das seguintes finalidades: [...] III - impedir a influência do réu no ânimo de testemunha ou da vítima, desde que não seja possível colher o depoimento destas por videoconferência, nos termos do art. 217." (destaque nosso).

82 “Art. 240. A busca será domiciliar ou pessoal. $\S 1^{\circ}$ Proceder-se-á à busca domiciliar, quando fundadas razões a autorizarem, para: [...] g) apreender pessoas vítimas de crimes.” (destaque nosso).

83 “Art. 302. Considera-se em flagrante delito quem: I - está cometendo a infração penal; II - acaba de cometê-la; III - é perseguido, logo após, pela autoridade, pelo ofendido ou por qualquer pessoa, em situação que faça presumir ser autor da infração; IV - é encontrado, logo depois, com instrumentos, armas, objetos ou papéis que façam presumir ser ele autor da infração.” (destaque nosso).

84 “Art. 68. Quando o titular do direito à reparação do dano for pobre (art. $32, \S \S 1^{\circ}$ e $2^{\circ}$ ), a execução da sentença condenatória (art. 63) ou a ação civil (art. 64) será promovida, a seu requerimento, pelo Ministério Público.” (destaques nossos).

85 “Art. 119. As coisas a que se referem os arts. 74 e 100 do Código Penal não poderão ser restituídas, mesmo depois de transitar em julgado a sentença final, salvo se pertencerem ao lesado ou a terceiro de boafé." (destaque nosso).

86 “Art. 44. A queixa poderá ser dada por procurador com poderes especiais, devendo constar do instrumento do mandato o nome do querelante e a menção do fato criminoso, salvo quando tais esclarecimentos dependerem de diligências que devem ser previamente requeridas no juízo criminal." (destaque nosso).
} 
âmbito do processo penal, como o sujeito passivo da infração penal, seja o sujeito passivo principal ou o secundário, com base no que for preconizado no próprio tipo penal.

Em caso de dúvidas, desposa o acolhimento de uma interpretação mais extensiva, em razão da "tendência atual de abrir espaço para as vítimas do crime de participarem do processo criminal", de modo que, por exemplo, em crimes como o de furto, poderiam ser vítimas tanto o proprietário quanto o possuidor da coisa e, no crime de roubo, além do proprietário e do possuidor, a pessoa que sofreu a violência ou a grave ameaça. ${ }^{87}$

Registre-se que esse conceito de vítima (sujeito passivo da infração penal) coincide com a figura do ofendido, prevista no Código de Processo Penal (CPP).

$\mathrm{Na}$ literatura jurídica, também se registra o conceito de sujeito prejudicado. Oriundo do Direito Civil, esse conceito designa aquele "que sofreu danos patrimoniais em virtude de um delito", 88 o que parece corresponder aos termos titular do direito à reparação do dano ou lesado, referidos em dispositivos do CPP.

Importante ressaltar que o prejudicado pode ser sujeito passivo da infração penal, mas não o é obrigatoriamente, como atesta exemplo elucidativo citado pelo próprio FERNANDES. ${ }^{89}$

Assim, pode-se inferir que a figura da vítima, de gênese criminológica, encontra, na doutrina nacional, correspondência com o conceito de sujeito passivo da infração penal, de cunho penal, o qual, no âmbito do processo penal, ganha a denominação de ofendido, personagem esse que poderá ou não se habilitar como assistente, consoante as regras do CPP.

O personagem do sujeito prejudicado (titular do direito à reparação do dano ou lesado), por sua vez, ganha menor relevância nas normas processuais penais brasileiras, o que se explica à luz da tradição de separação entre as instâncias cível e penal, que tem nos acompanhado desde a Lei n. 261/1841, impondo ao sujeito prejudicado o ônus de perseguir a satisfação de seus interesses cíveis ex delicto fora do processo penal.

\footnotetext{
${ }^{87}$ FERNANDES, Antônio Scarance. O papel da vítima no processo criminal. São Paulo: Malheiros, 1995 , p. 51-52.

88 BARROS, Flaviane de Magalhães. A participação da vítima no processo penal. Rio de Janeiro: Lumen Juris, 2008, p. 60.

89 "Em acidente de trânsito, sofre lesões o filho do proprietário do veículo, estudante, sem rendimentos, ficando também avariado o automóvel; o filho será o sujeito passivo da infração penal, mas o seu progenitor o sujeito prejudicado porque pagou despesas diversas para tratamento do filho e para reparação do veículo. [...] considera-se vítima o sujeito passivo, principal ou secundário. O prejudicado só será vítima quando ostente também a qualidade de sujeito passivo. Assim, todo sujeito passivo será vítima, mas não todo prejudicado.”: (FERNANDES, Antônio Scarance. O papel da vítima no processo criminal. São Paulo: Malheiros, 1995, p. 49-50).
} 
Tal sistema de separação de instâncias, contudo, tem sofrido nos últimos anos, um processo de atenuação legislativa, ${ }^{90}$ que detectando os incômodos causados à vítima em razão de pleitear por indenização civil em instância diversa do processo penal, caminha a passos largos em direção à adoção de um novo sistema, o sistema da adesão, já se vislumbrando a possível incorporação no processo penal da parte civil e de seu pedido de recomposição de danos, preconizados no projeto de Código de Processo Penal. ${ }^{91}$

$\mathrm{Na}$ verdade, tendo em vista essa variedade de papéis e interesses que podem mover a atuação da vítima no processo penal, trazida pela literatura jurídica e amparada em dispositivos normativos processuais penais, pode-se questionar, com a devida vênia, os motivos que levam apenas o sujeito passivo da infração penal a ser considerado como vítima no âmbito do processo penal, negando-se ou simplesmente se olvidando de estender tal qualidade ao sujeito prejudicado.

Afinal, ambos - sujeito passivo da infração penal e sujeito prejudicado fazem-se merecedores de acolhida e proteção no processo penal, não somente em razão da origem comum da gênese de seus interesses - o mesmo fato típico-penal que serve de base ao processo -, bem como da necessidade de ambos defenderem tais interesses sob uma atuação processual efetiva. ${ }^{92}$

\subsubsection{A vitimização secundária}

O movimento vitimológico principiado no século anterior, ao volver sua atenção ao sistema de justiça penal, passou a detectar um tratamento processual dispensado à vítima bastante aquém do que se pode considerar como adequado. Esse tratamento mostra-se mesmo hábil, potencialmente, a causar tantos ou mais males do que a própria prática do crime, podendo configurar um novo processo de vitimização.

\footnotetext{
${ }^{90}$ A título exemplificativo pode ser citada a Lei n. 9.099/95 (Juizados Especiais) que instituiu a composição civil dos danos, e a Lei n. 11.719/08, que alterou o art. 387, inciso IV, do CPP, passando a prever a fixação de valor mínimo para reparação de danos em favor do ofendido.

${ }^{91}$ Esse projeto - originariamente PLS 156/09 - já ganhou aprovação inicial no Senado Federal, tendo sido remetido à Câmara dos Deputados para apreciação.

92 A progressiva valorização do sujeito prejudicado na legislação processual brasileira aqui apontada já permite a esse sujeito uma atuação dentro do próprio processo penal, atuação essa que ganha maior efetividade ao se considerar a perspectivação da parte civil no projeto de Código de Processo Penal, denotando, assim, essa necessidade de também o sujeito prejudicado ser investido no processo penal da condição de vítima, tal como sucede com o sujeito passivo da infração penal.
} 
Na verdade, pode-se falar em distintos processos de vitimização, responsáveis pela gênese da condição de vítima, que podem ser classificados em: a) vitimização primária: associada à prática da infração penal ${ }^{93}$ b) vitimização secundária: associada às instâncias de controle formal, mais especificamente, ao sistema de justiça penal; ${ }^{94} \mathrm{c}$ ) vitimização terciária: vinculada à falta de amparo do Estado e da ausência de receptividade social. $^{95}$

Para os fins do presente estudo, deve-se atentar exclusivamente sobre a vitimização secundária, que também recebe a denominação de sobrevitimização. ${ }^{96}$

Pode-se constatar, sem muito esforço, que o sistema de justiça penal e seu processo penal, a princípio, simplesmente olvidam a existência da vítima.

Para MANZANERA, “los Sistemas Contemporáneos de Justicia Penal, al parecer se han preocupado fundamentalmente de descobrir, capturar, juzgar, sentenciar, encarcelar o rehabilitar a los delincuentes, sin prestar mayor atención a las víctimas". ${ }^{97}$

Esse olvidamento, por si, já constitui grave desrespeito à dignidade da vítima, que se vê, muitas vezes, completamente alheia à justiça penal, sem maior acesso aos acontecimentos decorrentes do confronto processual protagonizado entre o Estado e o suposto autor do crime.

O sistema de justiça penal brasileiro é particularmente excludente da vítima da infração penal, concorrendo decisivamente para um quadro de vitimização secundária ou sobrevitimização, o que cumpre ser analisado, ainda que sob rápida visão panorâmica.

93 “A vitimização resultante do crime causa danos diversos, materiais, físicos, psicológicos. [...] A vitimização primária pode ainda ocasionar mudanças de hábitos, alterações de conduta. Algumas pesquisas revelam que as alterações de rotina mais frequente são: deixar de sair à noite e sair sempre acompanhado, instalação de ofendículas e também medidas autoprotetivas como aquisição de arma." (OLIVEIRA, Ana Sofia Schmidt de. A vítima e o direito penal: uma abordagem do movimento vitimológico e de seu impacto no direito penal. São Paulo: Revista dos Tribunais, 1999, p. 121).

94 “[...] a vitimização secundária, também denominada de sobrevitimização pode ser compreendida como aquela gerada a partir da atuação dos órgãos responsáveis pelo controle social, incluindo todo o aparato policial, que receberá os primeiros reclamos relacionados à vítima, até os sujeitos que participarão do processo penal: juízes, promotores, peritos oficiais e serventuários de justiça." (BARROS, Flaviane de Magalhães. A participação da vítima no processo penal. Rio de Janeiro: Lumen Juris, 2008, p.70).

95 "A vitimização terciária vem da falta de amparo dos órgãos públicos (além das instâncias de controle) e da ausência de receptividade social em relação à vítima. Especialmente diante de certos delitos considerados estigmatizadores, que deixam sequelas graves, a vítima experimenta um abandono não só por parte do Estado mas, muitas vezes, também por parte do seu próprio grupo social." (OLIVEIRA, Ana Sofia Schmidt de. A vítima e o direito penal: uma abordagem do movimento vitimológico e de seu impacto no direito penal. São Paulo: Revista dos Tribunais, 1999, p. 124).

96 “Cumpre afirmar que a sobrevitimização, expressão aqui usada como sinônima de vitimização secundária, foi preferida por demonstrar com maior eficácia o desvio de finalidade da atuação jurisdicional, porque reforça a noção de uma nova vitimização em decorrência do aparato processual penal, e não apenas de uma consequência da vitimização primária, como se denota da expressão 'vitimização secundária'”. (BARROS, Flaviane de Magalhães. A participação da vítima no processo penal. Rio de Janeiro: Lumen Juris, 2008, p. 70-71).

${ }^{97}$ MANZANERA, Luiz Rodríguez. Victimología. Cidade do México: Porrúa, 2010, p. 384. 
Antes de tudo, percebe-se que a importância da vítima como agente ou instrumento de controle social mostra-se por demais subvalorizada. De fato, a vítima chega a ser retratada como o gate-keeper do sistema judiciário-penal, "vez que, de regra, é ela quem através de suas declarações junto à Polícia, ao Ministério Público ou ao Tribunal, traz a lume o evento delitivo". 98

Todavia, o acesso da vítima à Polícia é bastante dificultado em razão da deficiência ou mesmo da mais completa falta de preparo do aparato policial em acolhê-la. O descaso e, muitas vezes, a desconfiança, inibem a aproximação da vítima junto à Polícia.

De fato, a investigação policial, pelo inquérito, transcorre, no mais das vezes, ao alvedrio da vítima, constituindo esta uma mera fonte para extração de informações, facilmente descartada após a obtenção dos dados e informações tidos por úteis pela autoridade policial, situação essa que se prolonga até a seara processual.

A vontade da vítima em relação à persecução penal pouco é levada em consideração, o que pode ser verificado à vista das minguadas hipóteses de ação penal de iniciativa privada, assim como das insuficientes hipóteses de ação penal de iniciativa pública condicionada à representação.

A própria representação, entendida como autorização/consentimento para persecução penal oficial, não pode ser retratada após o ajuizamento da ação penal pelo Ministério Público.

Assim, em muitos casos em que circunstâncias supervenientes fazem perecer o interesse da vítima na persecução penal, processos tramitam mesmo contra a manifesta e inequívoca vontade da vítima do caso, em franco prejuízo dos interesses desta e do próprio acusado.

A participação da vítima na persecução penal, em ações penais de iniciativa privada, principal ou subsidiária, é desestimulada pelos custos de um processo e, em se tratando de vítima economicamente hipossuficiente, pela deficiência estrutural e falta de quadro pessoal que atinge as Defensorias Públicas dos Estados e da União.

Quanto à participação da vítima, sob o viés da colaboração com o Ministério Público, em casos de ação penal de iniciativa pública, sua atuação se mostra por demais limitada e por vezes meramente supletiva, encerrada sob as vestes do instituto da assistência, o qual não atende aos reclamos da dignidade da vítima.

Cumpre atentar ainda para outros aspectos, como o estado de ignorância em

${ }^{98}$ CÂMARA, Guilherme Costa. Programa de política criminal orientado para a vítima do crime. São Paulo: Editora Revista dos Tribunais; Coimbra: Coimbra Editora, 2008, p. 86-87. 
que é mantida a vítima quanto aos direitos que lhe assistem, bem como a dificuldade de aquela ter acesso a informações relativas ao desenvolvimento do inquérito policial e do processo; a falta de estrutura e de preparo para acolhimento das vítimas junto ao Ministério Público e ao Poder Judiciário; sua superexposição durante as investigações policiais e o processo penal, principalmente em se tratando de casos mais rumorosos e com repercussão na mídia etc.

Não se pode olvidar ainda a própria questão dos danos decorrentes da prática de infração penal, que o sistema de separação de instâncias adotado no Brasil insiste, por princípio, em manter distante do processo penal, impondo-se à vítima o ônus de pleitear seus direitos junto a instâncias diversas, pelo mesmo fato, explorando uma distinção jurídica entre interesses cíveis e penais que pouca importância representa para a vítima e seus anseios concretos em face da Justiça.

Tudo isso, sem prejuízo de outros aspectos, demonstra, à evidência, o abandono da vítima no processo penal, que vem sofrendo algumas atenuações, a bem da verdade, mas que ainda se mostram insuficientes para garantir a adequada observância dos direitos da vítima em processo penal, decorrentes dos desdobramentos do Princípio da Dignidade da Pessoa Humana, assunto que será abordado no próximo item.

\subsubsection{O Princípio da dignidade da pessoa humana e a vítima}

Consoante analisado no tópico anterior, o movimento de redescoberta tem encontrado a vítima, no âmbito do processo penal, sofrendo outro processo de vitimização, a denominada vitimização secundária ou sobrevitimização. Essa nova vitimização expõe o olvidamento e mesmo o desrespeito que os órgãos integrantes do sistema de justiça penal dispensam à vítima, tornando-se imperioso um verdadeiro resgate desta.

Pois bem, a ratio essendi que deve dar ensejo ao resgate da vítima dessa situação repousa no conceito de Dignidade da Pessoa Humana e na sua aplicabilidade em relação àquela. COMPARATO, atribuindo a tal conceito a qualidade de supremo modelo ético, investiga sua gênese e aponta-lhe fundamentos sob diversas perspectivas, como a religiosa (realçada pelo monoteísmo), antropológica filosófica (condição de animal racional e consciência individual e coletiva de sua singularidade no mundo) e científica 
(homem como ápice do processo de evolução). ${ }^{99}$ Em tal explanação, afirma de modo conciso que "o paradigma da pessoa humana reúne em si a totalidade dos valores; ela é o supremo critério axiológico a orientar a vida de cada um de nós". 100

No mesmo diapasão, BARCELLOS chega a asseverar que "um dos poucos consensos teóricos do mundo contemporâneo diz respeito ao valor essencial do ser humano", complementando que "[...] o fato é que a dignidade da pessoa humana, o valor do homem como um fim em si mesmo, é hoje um axioma da civilização ocidental, e talvez a única ideologia remanescente." 101

Sob o prisma jurídico, o Princípio da Dignidade da Pessoa Humana - que encontra previsão no ordenamento brasileiro na Constituição Federal de 1988, como um dos fundamentos do Estado Democrático de Direito brasileiro (art. $1^{\circ}$, inciso III) - serve como o princípio de maior hierarquia valorativa dentre todos os princípios constitucionais, merecendo a qualificação de "epicentro axiológico da ordem constitucional". ${ }^{102}$

Impende observar mais de perto a influência da Dignidade da Pessoa Humana no processo penal, bem como seus desdobramentos. Conforme já referido por ocasião da análise da fase de neutralização, pode-se asseverar resumidamente que a tomada, pelo Estado, do conflito penal para si, provocou os seguintes efeitos: o olvidamento da pessoa da vítima e a utilização da repressão como um instrumento de afirmação do poder político do soberano.

Sob esse segundo efeito, a prática disseminada de tortura e a aplicação de castigos cruéis e desumanos passaram a consistir em uma demonstração simbólica da superioridade do soberano sobre os súditos.

Coube a pensadores da época do Iluminismo - sendo o de maior notoriedade Cesare Bonesana, o Marquês de Beccaria - desenvolver ideias que justificassem restrições a esse poder absoluto, no que se denomina esse pensamento de iluminismo penal ou penalismo ilustrado, o qual se espraiou pelo continente europeu ${ }^{103}$, construindo "bases sólidas que instrumentalizaram uma reação ao arbítrio jurídico e político da Idade Média, o

\footnotetext{
${ }^{99}$ COMPARATO, Fábio Konder. Ética. São Paulo: Companhia das Letras, 2006, p. 478-483.

${ }^{100}$ COMPARATO, Fábio Konder. Ética. São Paulo: Companhia das Letras, 2006, p. 481.

${ }^{101}$ BARCELLOS, Ana Paula. A eficácia jurídica dos princípios constitucionais: o princípio da dignidade da pessoa humana. Rio de Janeiro: Renovar, 2002, p. 103-104. Nessa mesma obra, vale a pena conferir a análise que referida autora faz sobre o desenvolvimento de tal conceito (p. 103-121).

102 CARVAlHO, Luís Gustavo Grandinetti Castanho de. Processo penal e constituição: princípios constitucionais do processo penal. Rio de Janeiro: Lumen Juris, 2006, p. 22.

103 Sobre o penalismo ilustrado e seus representantes em língua francesa, inglesa, alemã, espanhola, portuguesa e italiana, cf. ANITUA, Gabriel Ignacio. Histórias dos pensamentos criminológicos. Tradução de Sérgio Lamarão. Rio de Janeiro: Revan, 2008. (Coleção pensamento criminológico, 15), p. 164-188.
} 
que possibilitou a concepção de que o acusado tem o direito inafastável de exercer sua defesa de forma ampla e regulada por lei."104-105

O penalismo ilustrado teve forte associação com o que se concebe hoje como Dignidade da Pessoa Humana, podendo-se afirmar que o sentimento de dignidade do homem, captado à época pelos iluministas penais, levou-os a deflagrar o início de um verdadeiro processo de humanização do processo penal, ao focar a perspectiva da dignidade da pessoa do acusado.

De fato, o penalismo ilustrado serviu como inspiração para a contestação do sistema inquisitivo, e para sua suplantação pelo sistema acusatório e seus caracteres, como a separação das funções de acusar, defender e julgar.

Segundo CARVALHO, não obstante o impulso inicial da suplantação do sistema inquisitivo, o sistema acusatório, à época do século XVIII, ainda não tinha o acusado na perspectiva de sujeito de direitos. Essa nova perspectiva somente viria a ser desenvolvida no século XIX, com a teorização do processo como relação jurídica, por influência de WACH e de BÜLLOW. ${ }^{106}$

Ainda segundo CARVALHO, o incipiente sentimento de dignidade do homem, que serviu de referência para o penalismo ilustrado, e "que formulou as bases teóricas da volta ao sistema acusatório e ensejou o ambiente para a os estudos da relação processual, evoluiu no princípio da dignidade, que, hoje, o abriga e consagra", citando como garantias decorrentes da Dignidade da Pessoa Humana, no processo penal, o contraditório, a ampla defesa, a isonomia, dentre outros. ${ }^{107}$

Essa ideia de dignidade do homem, que se traduz em um supremo modelo ético - para usar a expressão de COMPARATO - e que posteriormente ganhou dimensão de princípio jurídico, conferiu ao processo penal um caráter mais humanitário. $\mathrm{O}$ acusado,

104 CARVAlHO, Luís Gustavo Grandinetti Castanho de. Processo penal e constituição: princípios constitucionais do processo penal. Rio de Janeiro: Lumen Juris, 2006, p. 25.

105 ZAFFARONI cita as reformas legislativas imediatamente inspiradas no penalismo ilustrado, como a reforma levada a cabo pelo Grão-Duque de Toscana, em 1876, que praticamente pôs fim à pena de morte, a instrução da imperatriz Catarina II, de 1767, e o Código Josefino, na Áustria, de 1787. (ZAFFARONI, Eugenio Raúl; PIERANGELLI, José Henrique. Manual de direito penal brasileiro: parte geral. 8. ed. rev. atual. São Paulo: Revista dos Tribunais, 2009. v. 1, p. 183-184).

106 “[...]. Somente no século XIX, a partir das obras de Wach e, principalmente, de Bülow é que se iniciou a teorização da concepção do processo como relação jurídica em que o réu, tanto como o autor da ação, passa a ser reconhecido como sujeito de direitos, deveres, faculdades e ônus processuais. A importância dessa teorização consiste, em outras palavras, no reconhecimento de que o réu deixou definitivamente de ser objeto do processo para ser sujeito da relação processual, titular de direitos processuais e apto a exercê-los em igualdade de condições em relação ao autor da demanda". (CARVALHO, Luís Gustavo Grandinetti Castanho de. Processo penal e constituição: princípios constitucionais do processo penal. Rio de Janeiro: Lumen Juris, 2006, p. 25).

107 CARVALHO, Luís Gustavo Grandinetti Castanho de. Processo penal e constituição: princípios constitucionais do processo penal. Rio de Janeiro: Lumen Juris, 2006, p. 26. 
investido na condição de sujeito de direitos, passou a contar com um verdadeiro arsenal jurídico à sua disposição, limitador e oponível à persecução do Estado e ao arbítrio do Monarca. O ser humano (acusado), assim, passou a contar a seu favor com instrumentos que lhe possibilitassem defender-se do outrora todo-poderoso Estado.

Dessa forma, um dos efeitos causados pela tomada do conflito penal pelo Estado - a utilização da repressão como um instrumento de afirmação do poder político do soberano -, percebida sua nocividade, passou a ser paulatinamente combatido.

Ocorre que o efeito supérstite - o olvidamento da pessoa da vítima permaneceu incólume, acarretando a já referida vitimização secundária. Somente a partir do movimento vitimológico é que esse efeito passou a ser sistematicamente identificado, discutido, questionado, apontando-se-lhe a nocividade. Na verdade, as ideias trazidas pelo movimento vitimológico, dado seu desenvolvimento histórico recente, ainda se encontram em estágio de sedimentação, de modo que se aproxima a hora de também esse efeito da tomada do caso penal pelo Estado ser combatido.

Nesse ponto, cabe assinalar que perspectivação da vítima como sujeito de direitos e a incorporação gradual de direitos e de garantias que possibilitem seu exercício assim como aconteceu em relação ao acusado - pode ser considerada como um novo desdobramento da Dignidade da Pessoa Humana no âmbito do processo penal. Antes voltado ao acusado, esse princípio agora passa a estender-se também sobre a situação da vítima.

De fato, a Dignidade da Pessoa Humana não pode ser entendida de modo estanque nem atribuível, em processo penal, a apenas um dos envolvidos no caso penal, o acusado, sob pena de se incorrer em grave injustiça, deixando a vítima ao desamparo e com sua dignidade exposta e vilipendiada.

A Dignidade da Pessoa Humana, em razão de sua natureza axiológica, desenvolve-se conforme o perpassar das circunstâncias históricas. ${ }^{108} \mathrm{E}$ hoje, após a influência do movimento vitimológico, a dignidade da vítima sobressai, exigindo cada vez mais um amparo mais efetivo e não meramente tópico.

Essa maior incidência do Princípio da Dignidade da Pessoa Humana sobre o

\footnotetext{
${ }^{108}$ Nesse sentido, esclarecedoras as palavras de COMPARATO: “[...] os valores éticos não são visualizados pelo homem uma vez por todas e completamente, mas descobertos pouco a pouco, no curso da História. A pessoa é um modelo, ao mesmo tempo transcendente e imanente à vida humana, um modelo que se perfaz indefinidamente e se concretiza, sem cessar, no desenvolvimento das sucessivas etapas históricas. Ao contrário da noção estóica de natureza que existe na base ou origem de tudo e não muda nunca, a concepção dos valores evolui e aponta claramente para o objetivo de constante e ilimitado aperfeiçoamento do ser humano”. (COMPARATO, Fábio Konder. Ética. São Paulo: Companhia das Letras, 2006, p. 481).
} 
processo penal, compreendendo não somente a tutela do acusado, mas a novel tutela da vítima, que ainda se acha em desenvolvimento, terá por condão consolidar a humanização do processo penal, deflagrada pelo penalismo ilustrado, que precisará ter como foco um conflito humano, priorizando a solução real desse conflito, ao atentar para os problemas, anseios e interesses das pessoas reais envolvidas (acusado, vítima e coletividade), em detrimento de uma mera resposta jurídico-formal abstrata. ${ }^{109}$

\subsubsection{Aperfeiçoando a tutela da vítima no processo penal}

O Princípio da Dignidade da Pessoa Humana, conforme já asseverado, por exigência do movimento de redescoberta da vítima, passa a estender-se além do acusado, alcançando, em um desdobramento posterior, a própria vítima da infração penal. Assim, não somente o acusado, mas também a vítima precisa ter sua dignidade reconhecida pelo ordenamento jurídico.

O reconhecimento dessa dignidade da vítima no processo penal não pode ser viabilizado sem que seja assegurada uma tutela de seus direitos e garantias. Sobre referida tutela, chega-se a falar em Derecho Victimal, expressão de origem hispânica que entre nós poderia ser traduzida por Direito da Vítima ou Direito Vitimal.

Para conhecer esse ramo jurídico que pugna por autonomia, faz-se preciso recordar que a concepção moderna de Direito Penal parte de uma abstração do conflito penal concreto, travado originariamente entre o suposto autor do delito e vítima, interpondo-se o Estado como sujeito passivo necessário ou constante em toda e qualquer infração penal. À ofensa à vítima substituiu-se a ofensa ao ordenamento jurídico-estatal. A vítima concreta, diretamente ofendida pelo delito, passa a uma posição secundária, a de sujeito passivo eventual e seus interesses na solução do caso são olvidados ou mesmo remetidos ao âmbito cível, ao passo que todo o maquinário jurídico-repressivo estatal se volve para aplicação da pena em face da violação ao ordenamento jurídico-penal.

\footnotetext{
109 "El sistema penal y concretamente el Derecho Penal y Procesal Penal debe abandonar el modelo de justicia tradicional que considera el delito como un hecho objetivo y despersonalizado, para construir un nuevo modelo que fije su atención en la concepción del delito como un conflito humano que tiene como protagonista principal al hombre (víctima y victimario), abandonando la idea de un sistema penal alejado del hombre, exclusivamente retributivo y vingativo por un sistema que se convierta en instrumento de reconciliación y paz." (SAMPEDRO ARRUBLA, Júlio Andrés. Por la humanización del proceso penal. In: MESSUTI, Ana. (Coord.). Perspectivas criminológicas en el umbral del tercer milenio. Montevidéu: Fundación de Cultura Universitaria, 1998. p. 75-82, p. 75-76).
} 
O alheamento da vítima mostra-se evidente ao se questionar sobre os fins do Direito Penal. FERRAJOLI, por exemplo, após discorrer sobre as teorias construídas ao longo dos séculos sobre a pena, atribui ao Direito Penal, em tom de conclusão, duas finalidades: a prevenção dos delitos e a prevenção de penas arbitrárias ou desmedidas contra o autor da infração. ${ }^{110}$ Como se vê, em tal concepção, há espaço para os interesses da sociedade e os interesses do suposto autor da infração, porém, os interesses da vítima passariam ao largo da mira do Direito Penal.

Partindo de tais constatações, passou-se a insistir que a tutela dos direitos das vítimas de infração penal não encontraria lugar dentro do Direito Penal, propondo-se um ramo jurídico específico que tivesse por objeto esses direitos, que passaria a denominar-se Derecho Victimal. ${ }^{111}$

Em defesa da implementação de tal ramo jurídico, MAISONNAVE enfatiza que o Direito Vitimal não precisaria necessariamente de um código próprio, devendo-se adotar suas pautas vitimológicas nas leis penais materiais e processuais, o que teria ocorrido de modo semelhante com os Direitos Humanos, cujos princípios encontram-se entrelaçados com os demais ramos do Direito. ${ }^{112}$

\footnotetext{
110 “[...] o direito penal tem como finalidade uma dupla função preventiva, tanto uma como a outra, negativas, quais sejam a prevenção geral dos delitos e a prevenção geral das penas arbitrárias ou desmedidas. A primeira função indica o limite mínimo, a segunda o limite máximo das penas. Aquela reflete o interesse da maioria não desviante. Esta, o interesse do réu ou de quem é suspeito ou acusado de sê-lo." (FERRAJOLI, Luigi. Direito e razão: teoria do garantismo penal. Tradução de Ana Paulo Zomer, Fauzi Hassan Choukr, Juarez Tavares e Luiz Flávio Gomes. São Paulo: Revista dos Tribunais, 2002, p. 269).

${ }^{111}$ Para o vitimólogo mexicano MANZANERA, "Queda claro pues, que estamos presenciando o nacimiento de una nova y prometedora rama del Derecho: el Derecho Victimal, cuyas bases están ya sentadas y que tiene diferencias claras y específicas con el Derecho Penal, que 'no' fue creado propiamente para proteger los derechos de las víctimas". (MANZANERA, Luis Rodriguez. Victimología. 12. ed. Cidade do México: Porrúa, 2010, p. 359). MANZANERA situa o Direito Vitimal dentro da Enciclopédia das Ciências Jurídicas, mais precisamente dentro do grupo jurídico-penal ou jurídico-repressivo, ao lado do Direito Penal, Direito Processual Penal, Direito de Execução Penal e Direito de Polícia. (MANZANERA, Luis Rodriguez. Victimología. 12. ed. Cidade do México: Porrúa, 2010, p. 56). A também mexicana MARIA DE LA LUZ LIMA MALVIDO recorda que o conceito de vítima, conforme consta no texto da Declaração da ONU, de 1985, engloba pessoas que, individual ou coletivamente, tenham sofridos danos, incluindo-se lesões físicas ou mentais, sofrimento emocional, perda financeira ou menoscabo substancial de seus direitos fundamentais, como consequência de ações ou omissões violadoras da legislação penal vigente, incluída a que proíbe o abuso de poder, bem como seus familiares ou dependentes imediatos e as pessoas que tenham sofrido danos ao intervir para ajudar a vítima em perigo ou para prevenir a vitimização. Ressaltando a diferença existente entre o conceito adotado pela ONU e o restrito conceito de sujeito passivo de Direito Penal, alega a referida professora que os fins da ciência do Direito Penal não podem ser estendidos a outro sujeito para o qual não foi estruturada e que não lhe cabe como objeto de estudo. Daí define o Direito Vitimal como o "conjunto de principios, valores, normas e procedimientos jurídicos locales, nacionales e internacionales, tendientes a requerir, posibilitar y controlar las prerrogativas y pretensiones de las víctimas de delitos y abuso de poder". (MALVIDO, Maria de La Luz Lima. Derecho Victimal. In: MARCHIORI, Hilda. (Coord.). La víctima desde una perspectiva criminológica: asistencia victimológica. Córdoba: Editora Universitaria Integral, 2004, p. 130).

${ }^{112}$ MAISONNAVE, Germán Aller. Derecho victimal. Revista Ibero-Americana de Ciências Penais, Porto Alegre, v. 2, n. 3, p. 103-111, mai./ago. 2001, p. 108-109.
} 
Ainda com base nas lições de MAISONNAVE, a busca pela vítima seria um elemento transcendente do Direito Vitimal, complementando a noção de delito e servindo para a criação e revisão de tipos penais em função da estrita presença de uma vítima constatável, o que representaria um aporte para a democratização do Direito Penal, pois se levaria em consideração necessariamente a vítima, que representa $50 \%$ do fato criminal. ${ }^{113}$

No México, por exemplo, a tutela dos direitos e garantias da vítima no processo penal encontra previsão na própria Constituição dos Estados Unidos do México, que por força de reformas sucessivas, verificadas nos anos de 1993, 2000 e 2008, contempla o artigo 20-C, ${ }^{114}$ o qual, em seus sete incisos, assegura um verdadeiro estatuto normativo de proteção à vítima, em que se acham compreendidos: direito à assistência jurídica, direito à informação, direito à participação, direito à atenção médica e psicológica de urgência, direito à reparação do dano, direito à privacidade e à proteção, direito a medidas cautelares, e direito à impugnação judicial quanto a omissões do Ministério Público. ${ }^{115}$

Semelhante dispositivo não encontra correspondência na Constituição brasileira. Não obstante, a Constituição Federal de 1988 inova o ordenamento, elevando a

${ }^{113}$ MAISONNAVE, Germán Aller. Derecho victimal. Revista Ibero-Americana de Ciências Penais, Porto Alegre, v. 2, n. 3, p. 103-111, mai./ago. 2001, p. 110.

114 O 20-A refere-se aos princípios gerais do processo penal, ao passo que o 20-B e o 20-C, preveem, respetivamente, os direitos do acusado e da vítima.

115 "Artículo 20. El proceso penal será acusatorio y oral. Se regirá por los principios de publicidad, contradicción, concentración, continuidad e inmediación. [...] C. De los derechos de la víctima o del ofendido: I. Recibir asesoría jurídica; ser informado de los derechos que en su favor establece la Constitución y, cuando lo solicite, ser informado del desarrollo del procedimiento penal; II. Coadyuvar con el Ministerio Público; a que se le reciban todos los datos o elementos de prueba com los que cuente, tanto en la investigación como en el proceso, a que se desahoguen las diligencias correspondientes, y a intervenir en el juicio e interponer los recursos en los términos que prevea la ley. Cuando el Ministerio Público considere que no es necesario el desahogo de la diligencia, deberá fundar y motivar su negativa; III. Recibir, desde la comisión del delito, atención médica y psicológica de urgencia; IV. Que se le repare el daño. En los casos en que sea procedente, el Ministerio Público estará obligado a solicitar la reparación del daño, sin menoscabo de que la víctima u ofendido lo pueda solicitar directamente, y el juzgador no podrá absolver al sentenciado de dicha reparación si ha emitido uma sentencia condenatoria. La ley fijará procedimientos ágiles para ejecutar las sentencias en materia de reparación del daño; $\boldsymbol{V}$. Al resguardo de su identidad y otros datos personales en los siguientes casos: cuando sean menores de edad; cuando se trate de delitos de violación, trata de personas, secuestro o delincuencia organizada; y cuando a juicio del juzgador sea necesario para su protección, salvaguardando en todo caso los derechos de la defensa. El Ministerio Público deberá garantizar la protección de víctimas, ofendidos, testigos y en general todas los sujetos que intervengan en el proceso. Los jueces deberán vigilar el buen cumplimiento de esta obligación; VI. Solicitar las medidas cautelares y providencias necesarias para la protección y restitución de sus derechos, y VII. Impugnar ante autoridad judicial las omisiones del Ministerio Público en la investigación de los delitos, así como las resoluciones de reserva, no ejercicio, desistimiento de la acción penal o suspensión del procedimiento cuando no esté satisfecha la reparación del daño." (http://www.diputados.gob.mx/LeyesBiblio/pdf/1.pdf. Acesso em: 21-12-2011. (MÉXICO)). Para um visão mais aprofundada sobre a tutela dos direitos da vítima no ordenamento jurídico mexicano: CAMPOS, Carlos Rodríguez. Aspectos historicos y reflexiones sobre la victimología y el derecho victimal em México, p.10-14. Disponível em: <http://www.funvic.org/vic_mex.pdf>. Acesso em: 29 dez. 2011. 
status constitucional, sob a forma de direitos e garantias fundamentais, tanto a obrigação de reparação do dano civil ex delicto (art. $5^{\circ}$, inciso XLV) - em prol das vítimas, é claro -, quanto o direito à ação penal de iniciativa privada subsidiária (art. $5^{\circ}$, inciso LIX), bem como prevê a instituição, na forma de lei ordinária: a) da justiça penal consensual, para infrações de pequeno potencial ofensivo (art. 98, inciso I); b) da assistência aos herdeiros e dependentes de vítimas de crime doloso por parte do Poder Público, na forma da lei, independentemente da responsabilidade civil do autor do delito (art. 245).

No que se refere à legislação infraconstitucional, percebe-se um grande avanço em prol de uma tutela dos direitos e garantias da vítima no processo penal brasileiro. $\mathrm{O}$ primeiro diploma legal mais significativo surgiu no ano de 1995. Foi a Lei n. 9.099/95 (Lei dos Juizados Especiais Cíveis e Criminais). Regulamentando o disposto no art. 98, inciso I, da Constituição Federal de 1998, essa lei instituiu, na prática, um novo modelo de justiça penal, baseado no consensualismo, em que a pessoa da vítima passa a ter presença assegurada em audiências preliminares, nas quais ganha vez e voz.

De fato, embora restrito a infrações de baixa lesividade, o rito do Juizado Especial Criminal passou a oportunizar, à vítima, a possibilidade, na aludida audiência preliminar, de celebrar composição civil de danos decorrentes do ilícito penal com o autor do fato, acordo esse que, uma vez homologado judicialmente na própria audiência, constituiria título executivo judicial em favor daquela (art. 74, caput). Esse mesmo acordo, em não se tratando de infração que enseje ação penal de iniciativa pública incondicionada, passou a ensejar a extinção de punibilidade, em prol do autor do fato (art. 74, p.u.).

Cumpre registrar ainda que a Lei n. 9.099/95 estendeu o direito de representação às ações penais de iniciativa pública em caso de crimes de lesão corporal leve e culposa (art. 88) - o que aumentou, por si só, e de forma significativa, o poder de disposição da vítima no processo penal -, bem como previu a suspensão condicional do processo (sursis processual), elencando, dentre suas condições, a reparação do dano civil ex delicto (art. $89, \S 1^{\circ}$, inciso I).

Seguiram-se outras leis ordinárias protetivas da vítima, embora de menor repercussão, por exemplo, a Lei n. 9.503/97 (Código de Trânsito Brasileiro), que instituiu a penalidade autônoma de multa reparatória, a ser aplicada em casos de danos materiais decorrentes de crimes de trânsito, a favor da vítima e de seus sucessores; a Lei n. 9.714/98 (Lei das Penas Alternativas), que deu nova redação ao inciso I, do art. 43, e ao $\S 1^{\circ}$, do art. 48, ambos do Código Penal, criando a pena de prestação pecuniária, cujo apurado deve ser revertido em favor da vítima e de seus dependentes; a Lei n. 9.807/99, que estabeleceu as 
bases para, no âmbito federal e no âmbito estadual, a implantação de programas estatais de proteção à vítima.

De edição mais recente, destacam-se duas leis, responsáveis por uma verdadeira microrreforma do Código de Processo Penal, que previram dispositivos de grande importância para as vítimas de delito: a Lei n. 11.690/2008, que remodelou o art. 201, do Código de Processo Penal, estabelecendo uma série de direitos para a vítima, e a Lei n. 11.719/2008, que, dando nova redação ao inciso IV, do art. 387, do Código de 1941, impôs ao juiz, por ocasião da sentença penal condenatória, a fixação de um valor mínimo para reparação de danos causados pelo delito.

Impende ainda registrar que algumas leis ordinárias conferiram mecanismos mais efetivos de proteção a vítimas pertencentes a certos grupos, dignos de proteção especial em razão de seu elevado risco vitimal, ${ }^{116}$ como as crianças e os adolescentes (Lei n. 8069/90), os idosos (Lei n. 10.741/2003) e as mulheres vítimas de violência doméstica (Lei n. 11.340/2006).

Essa tutela dos direitos e garantias da vítima em processo penal, já existente no processo penal brasileiro, embora já represente significativo avanço em relação ao tradicional olvidamento anterior, ainda se mostra insuficiente para evitar vitimização secundária, carecendo de maior aperfeiçoamento, a fim de assegurar maior respeito à dignidade das vítimas de infração penal. ${ }^{117}$

Feitas tais considerações, no propósito de sistematizar a análise da tutela disposta no ordenamento jurídico processual penal brasileiro, buscando soluções para seu aprimoramento, propõe-se a divisão, neste trabalho, dos direitos da vítima sob quatro vertentes distintas, reunindo, cada qual, grupos de direitos afins entre si. Seriam tais vertentes: a) direito à proteção; b) direito à informação; c) direito à participação; e, por fim, d) direito à solução consensual do processo.

\footnotetext{
${ }^{116}$ Sobre o conceito de risco vitimal, cf. MANZANERA, Luis Rodriguez. Victimología. 12. ed. Cidade do México: Porrúa, 2010, p. 431-433.

${ }^{117}$ Essa insuficiência da tutela jurídica em prol da vítima atualmente configurada constituirá objeto de análise nos capítulos seguintes.
} 


\section{DIREITOS DA VÍTIMA À PROTEÇÃO E À INFORMAÇÃO}

\subsection{CONSIDERAÇÕES GERAIS}

Como já afirmado anteriormente, a tutela da vítima no processo penal brasileiro ainda carece de aperfeiçoamento, tendo em vista que sua configuração atual ainda pode ensejar àquela o engendramento de processos de vitimização secundária.

Para fins didáticos, a análise sobre o aperfeiçoamento dessa tutela, ora proposta, esquematiza-se em grupos de direitos, reservando-se ao presente capítulo o tratamento aos direitos da vítima à proteção e à informação.

Deve-se frisar que a categoria do direito da vítima à proteção ora sugerida, por óbvio não pode ser entendida sob uma acepção ampla, de modo a confundir-se com a própria tutela pró-vítima, como gênero. Busca-se, com tal expressão (direito à proteção), uma acepção mais estrita, que, excluindo os direitos à participação, à informação e à solução do processo mediante consenso, possa compreender modalidades especiais de tutela que visem, dentro do possível, ao retorno da vítima ao status quo ante ou à redução dos efeitos deletérios provocados pela infração penal.

Para tanto, essas modalidades especiais de tutela abrangem aspectos bem diversificados relacionados à vítima, como sua integridade física, psíquica, seu bem-estar social etc.. Essas modalidades serão aqui analisadas como direito a um tratamento respeitoso, direito à proteção da segurança, direito à proteção da honra, da imagem e da privacidade, direito a uma assistência multidisciplinar (médica, psicológica, social, jurídica etc.) e direito a amparo econômico pelo Estado.

No que se refere ao direito à informação, sua importância é manifesta. A necessidade de receber informações acerca do trâmite procedimental coloca-se como fundamental para evitar o alheamento da vítima do processo, oportunizando-lhe o exercício de todos os demais grupos de direitos, a saber, os direitos à proteção, à participação e à solução consensual do processo.

No presente capítulo, parte-se do panorama da configuração atual dos direitos da vítima à proteção e à informação no processo penal brasileiro para, mediante a análise de normas e documentos internacionais, bem como de dispositivos afetos à matéria 
presentes no projeto de Código de Processo Penal que ainda tramita no Congresso Nacional, propor-se um aperfeiçoamento a tais direitos na sistemática processual penal brasileira (novas perspectivas).

\subsection{DIREITO DA VÍTIMA À PROTEÇÃO}

\subsubsection{O direito da vítima à proteção no atual processo penal brasileiro}

Para a vertente do ora denominado direito da vítima à proteção, propõem-se variados direitos e respectivas garantias que tenham em comum o objetivo de proteger a vítima que já se acha em uma situação vulnerável em decorrência da vitimização primária e ameaçada, ou mesmo já atingida, pelos processos de vitimização secundária e terciária.

Tal proteção busca inibir, minimizar e, se possível, reverter os processos de vitimização, ao assegurar à vítima um tratamento adequado, respeitoso e digno, a proteção de bens especialmente relevantes, como a segurança, e a privacidade, assim como a assistência multidisciplinar (assistência médica, psicológica, social, jurídica etc.) e o amparo econômico.

Eis, resumidamente, os principais dispositivos concernentes à vertente do direito à proteção, hoje existentes na legislação processual penal brasileira: direito a atendimento multidisciplinar, especialmente nas áreas psicossocial, jurídica e de saúde, às expensas do Estado ou do autor do delito (Código de Processo Penal, art. 201, §5º com redação dada pela Lei n. 11.690/08); direito à assistência social e de saúde e a medidas de proteção ao trabalho (Lei 11.340/06, art. $9^{\text {o118}}$ ); direito à separação física do acusado por ocasião da instrução (Código de Processo Penal, art. 201, $\$^{\circ}$, com redação dada pela Lei n. 11.690/08); direito à assistência jurídica no âmbito do processo penal, às expensas do Estado ou do autor do delito (Código de Processo Penal, art. 201, §5º com redação dada pela Lei n. 11.690/08), inclusive para atuação como assistente; direito às providências

\footnotetext{
${ }^{118} \mathrm{O}$ referido dispositivo legal assegura às mulheres em situação de violência doméstica ou familiar proteção exoprocessual, como direito à assistência social, à saúde e mesmo a medidas de proteção ao trabalho, como acesso prioritário à remoção no serviço público e manutenção do vínculo trabalhista, quando necessário o afastamento do local, por até seis meses.
} 
necessárias para preservação da honra, da privacidade e da imagem ${ }^{119}$ no curso do processo podendo, inclusive, determinar o segredo de justiça em relação aos dados, depoimentos e outras informações constantes dos autos a seu respeito para evitar sua exposição aos meios de comunicação (Código de Processo Penal, art. 201, §6 $6^{\circ}$, com redação dada pela Lei n. 11.690/08); direito a inserção em programas especiais de proteção (Lei n. 9.807/99).

Como se pode ver, o direito à proteção, em sua atual feição, já conta com alguma previsão legislativa, mormente em razão do advento da Lei n. 11.690/08, que conferiu nova redação ao art. 201, do Código de Processo Penal, acrescentando diversos direitos em prol da vítima. Contudo, muito ainda há o que aprimorar, conforme será analisado no próximo item.

\subsubsection{Novas perspectivas sobre o direito da vítima à proteção}

Para uma análise mais didática dessa vertente (direito da vítima à proteção), possibilitando-se um maior aprofundamento do tema, sugere-se aqui sua subdivisão em cinco tópicos: 1) direito a um tratamento respeitoso; 2) direito à proteção da segurança; 3) direito à proteção da privacidade; 4) direito a uma assistência multidisciplinar (médica, psicológica, social, jurídica etc.); e 5) direito a amparo econômico pelo Estado.

\subsubsection{Direito a um tratamento respeitoso}

A realidade tem demonstrado que o trato dispensado às vítimas, na praxe das instâncias da justiça penal, não se mostra condizente com sua dignidade, não se atentando aos anseios e necessidades mais básicos de quem sofre a prática da infração penal. Assim, vítimas não têm a devida acolhida pelas instituições estatais, são inquiridas com desconfiança, muitas vezes humilhadas e expostas a situações constrangedoras etc. ${ }^{120}$

\footnotetext{
${ }^{119}$ Para uma análise dos direitos de honra, imagem e privacidade em conexão com a liberdade de imprensa, cf.: GODOY, Cláudio Luiz Bueno de. A liberdade de imprensa e os direitos de personalidade. 2. ed. São Paulo: Atlas, 2008, p. 24-44.

${ }^{120}$ Sobre a desconfiança que costuma pairar sobre a vítima e a existência de um juízo de reprovabilidade sobre seus atos, as palavras de LEÃO: "Quero fazer mais uma observação sobre a vítima. O Professor Martin
} 
O direito a um tratamento respeitoso passa pelo necessário reconhecimento de que a vítima constitui verdadeiramente um sujeito de direitos e não um mero objeto processual, cuja utilidade resume-se à extração de informações.

Sob a perspectiva desse direito, ganha importância a noção de honra subjetiva, tida como a autoestima, o amor-próprio, o sentimento da própria dignidade e a consciência do próprio valor moral e social. ${ }^{121}$

A Declaração dos Princípios Básicos de Justiça Relativos às Vítimas da Criminalidade e de Abuso de Poder, da ONU (Resolução 40/34, de 29.11.1985), em seu anexo, art. $4^{\circ}$, estatui que "victims should be treated with compassion and respect for their dignity."122 No mesmo diapasão, a Decisão-quadro do Conselho da União Europeia Relativo ao Estatuto da Vítima em Processo Penal, de 15.03.2001, em seu art. $2^{\circ} .1$, prescreve que "as vítimas sejam tratadas com respeito pela sua dignidade pessoal."

A legislação brasileira não dispõe de nenhum dispositivo expresso e específico quanto ao reconhecimento do tratamento respeitoso da vítima, porém, convém assinalar que o projeto do novo Código de Processo Penal (substitutivo do PLS 156/09), já aprovado no Senado Federal, ${ }^{123}$ confere expressamente à vítima, em seu art. 91, inciso I, "o direito de ser tratada com dignidade e respeito."

Deve-se enfatizar ainda que as previsões normativas sobre o direito a um tratamento respeitoso não podem prescindir da promoção de uma reeducação de policiais, promotores, juízes, e servidores, para lidar dignamente com a vítima em todas as instâncias do sistema de justiça penal, abandonando-se uma abordagem fria ou preconceituosa em prol de um verdadeiro acolhimento no sistema, evitando-se, assim, novos processos de vitimização.

Simons, da Escola de Medicina da Universidade de Nova York, apontou a forma negativa com que a sociedade trata as vítimas, isto é, ela busca no comportamento da mesma a razão de ter sido vítima. Existem os juízes de reprovabilidade. Quando alguém tem um relógio furtado, diz-se: quem mandou sair com ele? Quando o sujeito vai ao banco e retira dinheiro, que normalmente coloca no bolso ou na bolsa, mas é furtado, logo se pensa: quem mandou sair do banco com dinheiro? Não é assim que acontece? Acho que todos aqui já foram furtados, e todos já sofreram esse Juizo. Quem mandou andar naquela rua deserta? Você tem certeza que fechou a porta do carro, quando o furtaram? Por que não gritou?" (LEÃO, Nilzardo Carneiro. A vítima e o processo penal. In: KOSOVSKI, Ester; PIEDADE JÚNIOR, Heitor (Coord.). Temas de vitimologia II. Rio de Janeiro: Lumen Juris, 2001, p. 103-110, p. 108).

${ }^{121}$ Cf. GODOY, Cláudio Luiz Bueno de. A liberdade de imprensa e os direitos da personalidade. 2. ed. São Paulo: Atlas, 2008, p. 28.

${ }^{122}$ Em livre tradução nossa: "As vítimas devem ser tratadas com compaixão e respeito por sua dignidade".

${ }^{123}$ Cf. BRASIL. Congresso. Senado. Projeto de Lei do Senado no 156/09: redação final. Disponível em: <http://www.senado.gov.br/atividade/materia/getPDF.asp?t=85509\&tp=1>. Acesso em: 15 mar. 2011. 


\subsubsection{Direito à proteção da segurança}

O estado de vulnerabilidade da vítima pode ensejar-lhe ameaças ou atos de violência por parte do suposto autor da infração penal e de terceiros, mormente quando se detecta a intenção daquela em colaborar com a persecução penal, fazendo-se necessária uma tutela especial que tenha por objeto proteger sua segurança (em especial, sua vida e sua integridade física e psíquica). A essa tutela denomina-se aqui direito da vítima à proteção da segurança.

Para propiciar essa modalidade de proteção à vítima, o ordenamento jurídico já conta com a Lei n. 9.807/99, bem como com o Sistema Nacional de Assistência a Vítimas e a Testemunhas Ameaçadas, que é composto pelo Programa Federal de Assistência a Vítimas e a Testemunhas Ameaçadas, regulamentado pelo Decreto $\mathrm{n}^{\mathbf{o}}$ 3.518/00, e pelos Programas Estaduais de Proteção.

Consoante a Lei n. 9.807/99, “a proteção concedida pelos programas e as medidas dela decorrentes levarão em conta a gravidade da coação ou da ameaça à integridade física ou psicológica, a dificuldade de preveni-las ou reprimi-las pelos meios convencionais e a sua importância para a produção da prova" (art. $2^{\circ}$, caput), sendo que sobre tais circunstâncias, por ocasião da admissão ou da exclusão do programa, deverá ser previamente consultado o Ministério Público (art. $3^{\circ}$ ).

A proteção em face dos programas poderá ser "dirigida ou estendida ao cônjuge ou companheiro, ascendentes, descendentes e dependentes que tenham convivência habitual com a vítima ou testemunha, conforme o especificamente necessário em cada caso" (art. $\left.2^{\circ}, \S 1^{\circ}\right)$.

A Lei em questão, a par do $\S 1^{\circ}$ de seu art. $2^{\circ}$, exclui da proteção pessoas “cuja personalidade ou conduta seja incompatível com as restrições de comportamento exigidas pelo programa, os condenados que estejam cumprindo pena e os indiciados ou acusados sob prisão cautelar em qualquer de suas modalidades."

A solicitação, objetivando o ingresso da vítima no programa federal ou estadual poderá ser encaminhada ao órgão executor pelo interessado, pelo Ministério Público, pela autoridade policial que conduz a investigação criminal, pelo juiz competente para a instrução do processo criminal ou por órgãos públicos e entidades com atribuições de defesa dos direitos humanos (art. $5^{\circ}$ ), tendo sempre por requisito a anuência da vítima. 
Em situações de urgência, conforme estabelecido no art. $5^{\circ}, \S 3^{\circ}$, da Lei n. 9.807/99, encontra-se prevista a possibilidade de prevê a possibilidade de a vítima submeter-se provisoriamente a custódia de órgão policial, aguardando-se a decisão do conselho deliberativo sobre sua inclusão ou não no programa.

Por fim, a Lei enuncia, exemplificativamente, em seu art. $7^{\circ}$, as medidas que podem ser adotadas em prol da vítima, a saber: segurança na residência, incluindo o controle de telecomunicações, escolta e segurança nos deslocamentos da residência, inclusive para fins de trabalho ou para a prestação de depoimentos, transferência de residência ou acomodação provisória em local compatível com a proteção, preservação da identidade, imagem e dados pessoais, ajuda financeira mensal para prover as despesas necessárias à subsistência individual ou familiar, no caso de a pessoa protegida estar impossibilitada de desenvolver trabalho regular ou de inexistência de qualquer fonte de renda, suspensão temporária das atividades funcionais, sem prejuízo dos respectivos vencimentos ou vantagens, quando servidor público ou militar, apoio e assistência social, médica e psicológica, sigilo em relação aos atos praticados em virtude da proteção concedida e apoio do órgão executor do programa para o cumprimento de obrigações civis e administrativas que exijam o comparecimento pessoal; em seu art. $9^{\circ}$, o diploma legal em questão trata da hipótese excepcional de alteração do nome completo da vítima, de seu cônjuge ou companheiro, de seus ascendentes, descendentes e dependentes que tenham convivência habitual com aquela.

Segundo dados da Secretaria de Direitos Humanos da Presidência da República, no término do ano de 2011, dezessete (17) entes da Federação contavam com programas de proteção no respectivo âmbito estadual, tendo tais programas capacidade média de atendimento para trinta (30) vagas, as quais são destinadas não somente para as vítimas, familiares ou dependentes, mas também para testemunhas, e familiares ou dependentes destas. ${ }^{124}$

Como se vê, nem todas as unidades federativas dispõem de programas protetivos específicos, fazendo-se necessária a atuação supletiva do programa federal. $\mathrm{O}$ número reduzido de vagas e falta de verbas específicas para implementação efetiva das medidas também se mostram como elementos dificultadores, o que contribui, somando-se ao desconhecimento geral da existência de tal sistema de proteção, para que tais programas

\footnotetext{
${ }^{124}$ BRASIL. Presidência da República. Secretaria de Direitos Humanos. Sistema nacional de assistência a vítimas e testemunhas ameaçadas. Disponível em: $<$ http://www.direitoshumanos.gov.br/protecao/Id prot testemunha/Id prot sist. Acesso em: 22-12-2011.
} 
tenham aplicação rara na realidade do sistema de justiça penal brasileiro.

Além dos programas de proteção, medidas ainda mais simples poderiam ser tomadas, em prol de se garantir esse direito à segurança da vítima. Por exemplo, o efetivo cumprimento do disposto no Código de Processo Penal, art. 201, §4 , com redação recentemente dada pela Lei n. 11.690/08, que assegura o direito à separação física do acusado por ocasião da instrução. ${ }^{125}$

Os órgãos encarregados da direção dos fóruns espalhados no país têm, assim, o dever de destinar espaço exclusivo às vítimas, distinto do espaço reservado aos acusados, cabendo ainda à equipe responsável pela segurança do edifício preservar as vítimas de qualquer contato com os supostos autores de infração penal, evitando-se situações constrangedoras e muitas vezes intimidadoras.

De bom grado também seria a valorização e a incrementação da fiscalização das medidas cautelares pessoais diversas da prisão cautelar, que possam beneficiar diretamente a pessoa da vítima e sua segurança pessoal, como as medidas previstas no art. 319, inciso II ("proibição de acesso ou frequência a determinados lugares quando, por circunstâncias relacionadas ao fato, deva o indiciado ou acusado permanecer distante desses locais para evitar o risco de novas infrações") e III ("proibição de manter contato com pessoa determinada quando, por circunstâncias relacionadas ao fato, deva o indiciado ou acusado dela permanecer distante"), instituídas pela novel Lei n. 12.403/11, bem como das medidas protetivas de urgência estabelecidas nos casos de violência doméstica (Lei n. 11.340/06).

Tais medidas, além de preservar em maior grau a liberdade dos acusados - em atenção ao princípio da proporcionalidade -, atendem à peculiar situação das vítimas, respeitando o direito à proteção de sua segurança.

Entretanto, há de se observar que a inexistência de quadro de pessoal e de estrutura apropriada que propiciem a observância de tais medidas, torna-as desprovidas de eficácia, ensejando riscos para a vítima e colocando em xeque a própria credibilidade do sistema de justiça penal.

3.2.2.3 Direito à proteção da honra, da imagem e da privacidade

125 “§ $4^{\circ}$ Antes do início da audiência e durante a sua realização, será reservado espaço separado para o ofendido." 
A Constituição Federal de 1988, em seu art. 5º X, estabelece a inviolabilidade da intimidade, da vida privada, da honra e da imagem da pessoa, o que deve estender-se não somente aos acusados da prática de infração penal, mas também às vítimas de tais infrações.

Faz-se imprescindível aqui apresentar uma distinção entre esses conceitos, buscando uma melhor compreensão da tutela em comento.

Sobre a honra, "trata-se de um direito inato, natural e universal da pessoa humana, cujo conteúdo está não só no sentimento e consciência de ser digno, mas também na estima e na consideração moral dos outros". ${ }^{126}$

A proteção em testilha refere-se de modo mais especial à honra em sentido objetivo, ou seja, a honra social, "o conceito de que o individuo desfruta perante a sociedade: o apreço, o respeito que se lhe devota, a fama e a reparação que ostenta", ${ }^{127}$ bem esse facilmente vilipendiável pela mídia.

Outro direito, o direito à imagem, que se refere à representação da pessoa, por vezes sofre confusão com o direito à honra, contudo, trata-se de direitos distintos. Para GODOY, o direito à imagem pode ser violado sem qualquer atentado contra a honra de uma pessoa, citando-se o exemplo da doutrina laboral, “[...] em que fotografia, de uso autorizado para determinada campanha, é também utilizada para fim outro, de propaganda da agência encarregada daquele primeiro trabalho. Violou-se o direito à imagem, sem qualquer maltrato do direito à honra da pessoa fotografada". ${ }^{128}$

Quanto ao direito à privacidade, segue-se, neste estudo, a linha de SILVA que, sob tal denominação, compreende o direito à intimidade e o direito à vida privada, tomando o conceito de privacidade como "o conjunto de informação acerca do indivíduo que ele pode decidir manter sob seu exclusivo controle, ou comunicar, decidindo a quem, quando, onde e em que condições, sem a isso ser legalmente sujeito". ${ }^{129}$

\footnotetext{
${ }^{126}$ GODOY, Cláudio Luiz Bueno de. A liberdade de imprensa e os direitos de personalidade. 2. ed. São Paulo: Atlas, 2008, p. 29.

${ }^{127}$ GODOY, Cláudio Luiz Bueno de. A liberdade de imprensa e os direitos de personalidade. 2. ed. São Paulo: Atlas, 2008, p. 30.

${ }^{128}$ GODOY, Cláudio Luiz Bueno de. A liberdade de imprensa e os direitos de personalidade. 2. ed. São Paulo: Atlas, 2008, p. 36.

${ }^{129}$ SILVA, José Afonso da. Curso de direito constitucional positivo. 16 ed. São Paulo: Malheiros, 1999. p. 209. Sobre a distinção entre vida privada e intimidade, para GODOY, “[...] insiste-se em que esta se contenha naquela. Para Jean Carbonnier, enquanto a privacidade é, de maneira mais ampla, o próprio modo de vida da pessoa, sua intimidade encerra uma esfera reservada a impor que os outros a deixem tranquila. Ou, na lição de Tércio Sampaio Ferraz Júnior, 'a intimidade é o âmbito exclusivo que alguém reserva para si, sem nenhuma repercussão social, nem mesmo ao alcance de sua vida privada que, por mais isolada que seja, é
} 
Feitos tais esclarecimentos, faz-se mister registrar que as vítimas, não raro, são demasiadamente expostas ao meio social em razão da repercussão que pode ensejar a prática da infração penal, o que se agrava exponencialmente em face da superexposição midiática atual. Essa superexposição, além de poder constituir uma forma de constrangimento à pessoa da vítima, pode causar-lhe, de forma indelével, danos à sua honra, à sua imagem e à sua privacidade, tornando-se necessária a atuação tutelar estatal.

A Decisão-quadro do Conselho da União Europeia Relativo ao Estatuto da Vítima em Processo Penal, de 15.03.2001, em seu art. 8.2, prescreve que “[...] cada EstadoMembro garante a possibilidade de adoptar, se necessário, no âmbito de um processo judicial, medidas adequadas de proteção da privacidade e da imagem da vítima, da sua família ou de pessoas em situação equiparada".

Nessa esteira, a Lei n. 48/2007, de 29 de agosto, ensejou uma revisão no Código de Processo Penal português, o qual teve dentre suas metas o aumento da proteção à pessoa da vítima. ${ }^{130}$ Após essa revisão, o art. 88, 2, “c”, passou a proibir, “a publicação, por qualquer meio, da identidade das vítimas de crimes de tráfico de pessoas, contra a liberdade e autodeterminação sexual, a honra ou a reserva da vida privada", ressalvando, por exceções, o consentimento da vítima na revelação de sua identidade e a hipótese de o crime ser praticado através de órgão de comunicação social.

A tutela específica da honra, da imagem e da privacidade da vítima de infração penal passou a ser contemplada expressamente pelo art. 201, $\S 6^{\circ}$, do Código de Processo Penal, ${ }^{131}$ em decorrência da redação conferida pela Lei n. 11.690/08, prevendo-se a possibilidade de o juiz penal adotar as providências necessárias “à preservação da intimidade, vida privada, honra e imagem do ofendido, podendo, inclusive, determinar o segredo de justiça em relação aos dados, depoimentos e outras informações constantes dos

sempre um viver entre outros (na família, no trabalho, no lazer em comum)". (GODOY, Cláudio Luiz Bueno de. A liberdade de imprensa e os direitos de personalidade. 2. ed. São Paulo: Atlas, 2008, p. 40).

${ }^{130}$ Ao referir-se à aludida lei, MENDES afirma que "O aperfeiçoamento da legislação processual penal nunca é uma questão meramente técnica, axiologicamente neutra. Pelo contrário, o aperfeiçoamento ocorreu no quadro de determinados objetivos de política criminal, a saber: por um lado, o aumento da proteção concedida à vítima e, por outro, o reforço das garantias de defesa do arguido, mas compatibilizando-as com o desígnio de melhorar a eficácia do processo penal [...]”. (MENDES, Paulo de Sousa. Estatuto do arguido e posição processual da vítima. Revista Portuguesa de Ciência Criminal, Coimbra, n. 4, p. 601-612, out./dez. 2007, p. 602).

${ }^{131}$ Observe-se que o inciso IX, do art. 83, da CF/88, ("todos os julgamentos dos órgãos do Poder Judiciário serão públicos, e fundamentadas todas as decisões, sob pena de nulidade, podendo a lei limitar a presença, em determinados atos, às próprias partes e a seus advogados, ou somente a estes, em casos nos quais a preservação do direito à intimidade do interessado no sigilo não prejudique o interesse público à informação"), com redação conferida pela EC n. 45/94, já tratava da publicidade e do sigilo nos processos judiciais em geral, mas até o advento da Lei n. 11.690/08, não existia disposição legal específica em relação às vítimas em processo penal. 
autos a seu respeito para evitar sua exposição aos meios de comunicação."

Assim, por força do novo dispositivo legal, admite-se a decretação de providências para preservação de tais direitos, dentre as quais se destaca a possibilidade de declaração de sigilo sobre dados que possam servir para a identificação da vítima e de seus familiares, ou mesmo que possibilitem a identificação de seu endereço e de sua localização, evitando-se o acesso da mídia.

Cumpre registrar que uma vez decretado tal sigilo processual, sua violação por funcionário público - o que se aplica a juízes, promotores, servidores etc. - pode configurar o crime previsto no Código Penal, art. 325 (violação de sigilo funcional), e, caso cometido por advogado, pode configurar o tipo penal previsto no Código Penal, art. 154 (violação do segredo profissional).

Convém ainda destacar, em relação ao dispositivo legal referido ( $\operatorname{art.} 201, \S 6^{\circ}$ ), que este acaba tendo por efeito limitar o direito à liberdade de informação em face de situações concretas e individuais em que a vida privada, a intimidade, a honra ou a imagem da vítima da infração penal possam sofrer danos em decorrência da exposição levada a cabo pela mídia. Essa limitação acende um importante debate sobre os limites a tal liberdade de informação no âmbito do processo penal. ${ }^{132}$

Deve-se anotar também que seria recomendável que no processo penal brasileiro, em casos de crimes contra a honra (Título I, capítulo V do Título I, do Código Penal) e de crimes contra a dignidade sexual (Título VI, do Código Penal), à semelhança do que ocorre em Portugal, conforme já referido, a lei desde já assegurasse expressamente (ex lege) o sigilo dos dados das vítimas em face da mídia, independentemente de análise do caso pelo juiz. De qualquer forma, consoante o disposto no art. $201, \S 6^{\circ}$, nada impede que

\footnotetext{
${ }^{132}$ Sobre os limites à liberdade de informação: "As possibilidades de prejuízos aos bens jurídicos alheios por atos da imprensa, ou praticados por intermédio da imprensa, aumentam consideravelmente na sociedade contemporânea, em que os meios tecnológicos permitem várias formas de acesso a informações e possibilitam uma divulgação mais ampla, muitas vezes até mundial, acarretando danos irreparáveis. Tal realidade, porém, não autoriza a que simplesmente se condenem os órgãos de imprensa e que se engrosse o coro por maiores restrições à atuação dos profissionais de tais órgãos. A questão se torna ainda mais problemática quando se trata da divulgação de informações que dizem respeito a processos judiciais, principalmente os de natureza penal, uma vez que o processo penal resguarda interesses fundamentais da pessoa humana, os quais não podem ser vulnerados por uma divulgação precipitada na mídia. Assim, no processo penal, além dos direitos já elencados (honra, imagem, intimidade e privacidade), a presunção de inocência também impõe restrições à atividade dos meios de comunicação social. [...] Diga-se, por fim, que a fixação de critérios definidores do interesse público à informação do processo depende das situações concretas, vista a impossibilidade de uma determinação apriorística. Trata-se, porém, de uma tarefa essencial para que a publicidade do processo penal seja legítima e preservadora de garantias, sem se transformar em um espetáculo das misérias alheias". (SOUZA, Diego Fajardo Maranha Leão de; LEITE, Rosimeire Ventura. $\mathrm{O}$ sigilo no processo criminal e o interesse público à informação. In: FERNANDES, Antônio Scarance; ALMEIDA, José Raul Gavião de; MORAES, Maurício Zanoide de Moares (Coord.). Sigilo no processo penal: eficiência e garantismo. São Paulo: Revista dos Tribunais, 2008, p. 203-238, p. 219-221).
} 
o juiz da causa, em tais situações, determine o sigilo ex officio, prescindindo de pedido expresso da vítima para tanto.

\subsubsection{Direito a uma assistência multidisciplinar}

Conforme já visto, em não raros casos, a prática da infração penal acarreta à vítima uma situação de vulnerabilidade, muitas vezes agravada por sua condição socioeconômica desfavorecida. Assim, incumbe ao Estado resgatar essa vítima, ampará-la, de modo a restabelecer-lhe a dignidade violada. Para tanto, o Estado deve possuir um quadro de servidores devidamente qualificados para prestar às vítimas de infração penal assistência multidisciplinar, nas áreas médica, psicológica, social, jurídica etc.

Aqui também a Lei n. 11.690/08 modificou o art. 201 do Código de Processo Penal, acrescentando-lhe o $\S 5^{\circ}$, que dispõe sobre essa tutela em particular: "Se o juiz entender necessário, poderá encaminhar o ofendido para atendimento multidisciplinar, especialmente nas áreas psicossocial, de assistência jurídica e de saúde, a expensas do ofensor ou do Estado".

Deve-se atentar que a Lei confere ao juiz penal determinar medidas assistenciais imediatas em favor da vítima, medidas essas que fogem à prestação da tradicional jurisdição penal, constituindo verdadeiras providências protetivas em prol daquela.

Na verdade, o pioneirismo do estabelecimento de tais providências deve-se, não obstante em âmbito mais restrito, à Lei n. 11.340/06, que já previa a possibilidade de, em se tratando de violência doméstica, o juiz do feito encaminhar a vítima para atendimento médico, psicológico e social junto ao Sistema Único de Saúde (SUS) e ao hoje existente Sistema Único de Assistência Social (SUAS) $\left(\operatorname{art.} 9^{\circ}\right) .{ }^{133}$ Coube à Lei n. 11.690/08 ampliar algumas das medidas protetivas aos demais casos.

\footnotetext{
133 “Art. 9o A assistência à mulher em situação de violência doméstica e familiar será prestada de forma articulada e conforme os princípios e as diretrizes previstos na Lei Orgânica da Assistência Social, no Sistema Único de Saúde, no Sistema Único de Segurança Pública, entre outras normas e políticas públicas de proteção, e emergencialmente quando for o caso. $\S 1^{0} \mathrm{O}$ juiz determinará, por prazo certo, a inclusão da mulher em situação de violência doméstica e familiar no cadastro de programas assistenciais do governo federal, estadual e municipal. $\S 2^{\underline{o}} \mathrm{O}$ juiz assegurará à mulher em situação de violência doméstica e familiar, para preservar sua integridade física e psicológica: I - acesso prioritário à remoção quando servidora pública, integrante da administração direta ou indireta; II - manutenção do vínculo trabalhista, quando necessário o afastamento do local de trabalho, por até seis meses. $\S 3^{\underline{0}} \mathrm{~A}$ assistência à mulher em situação de violência
} 
Quanto aos custos de tal assistência, o Código de Processo Penal determina que devam ser suportados pelo Estado ou pelo próprio acusado. A viabilidade, contudo, de atribuir os custos de uma assistência multidisciplinar ao acusado mostra-se discutível, esbarrando na necessidade de anuência deste. De fato, na ausência de condenação transitada em julgado, por força do princípio da presunção de inocência, o acusado não pode se ver obrigado a custear assistência relativa às consequências da infração penal que se lhe imputa.

O que pode ser viabilizada é a condenação do acusado ao pagamento de prestação pecuniária, conforme previsto no art. $45, \S 1^{\circ}$, do Código Penal, ${ }^{134}$ ou de multa reparatória, conforme previsão no art. 297, do Código de Trânsito Brasileiro. ${ }^{135}$ Tais penas, que possuem conteúdo de ressarcimento de danos, passariam a cobrir os prejuízos da vítima em razão de gastos tidos com assistência multidisciplinar.

Dentro dessa tutela multifacetada, cabe especial destaque à assistência jurídica. A relevância do direito da vítima à assistência jurídica é manifesta, pois que aquela, via de regra leiga na ciência jurídica e na prática forense, carece de alguém que facilite seu ingresso no sistema de justiça penal, abrindo-lhe o leque dos demais direitos que lhe assistem.

Essa assistência jurídica deve ser disponibilizada, a princípio, pelas Defensorias Públicas dos Estados e da União, órgãos constitucionalmente encarregados de promover a defesa do pobre na forma da Lei.

Como, não raro, réus e vítimas pertencem a estratos menos favorecidos economicamente, nada impediria que, em um mesmo processo, um defensor público servisse, a exemplo, de advogado do assistente (a vítima), e outro defensor atuasse como advogado do acusado. Para tanto, é óbvio, faz-se necessária uma política efetiva, a nível federal e estadual, de fortalecimento da instituição da Defensoria Pública.

Por fim, impende assinalar que o projeto do Código de Processo Penal, em seu art. 91, inciso II, prevê, como um dos direitos da vítima, o recebimento, em caráter

doméstica e familiar compreenderá o acesso aos benefícios decorrentes do desenvolvimento científico e tecnológico, incluindo os serviços de contracepção de emergência, a profilaxia das Doenças Sexualmente Transmissíveis (DST) e da Síndrome da Imunodeficiência Adquirida (AIDS) e outros procedimentos médicos necessários e cabíveis nos casos de violência sexual."

134 "§ $1^{\circ}$ A prestação pecuniária consiste no pagamento em dinheiro à vítima, a seus dependentes ou a entidade pública ou privada com destinação social, de importância fixada pelo juiz, não inferior a 1 (um) salário mínimo nem superior a 360 (trezentos e sessenta) salários mínimos. O valor pago será deduzido do montante de eventual condenação em ação de reparação civil, se coincidentes os beneficiários".

135 “Art. 297. A penalidade de multa reparatória consiste no pagamento, mediante depósito judicial em favor da vítima, ou seus sucessores, de quantia calculada com base no disposto no $\S 1^{\mathrm{o}}$ do art. 49 do Código Penal, sempre que houver prejuízo material resultante do crime". 
imediato, de atendimento médico e atenção psicossocial, reforçando-se a necessidade da pronta atuação judicial quanto às medidas protetivas em prol da vítima.

\subsubsection{Direito a amparo econômico pelo Estado}

A indenização de prejuízos decorrentes da prática da infração penal incumbe, a princípio, ao autor dessa infração, devendo a Lei estabelecer à vítima mecanismos céleres e efetivos para propiciar a promoção de sua responsabilização civil, tema que ainda será objeto de apreciação neste estudo por ocasião da abordagem do direito da vítima à participação no processo penal.

Situações há, entretanto, em que essa indenização se mostra dificultada e até mesmo inviabilizada, como na hipótese em que o autor da infração penal sequer é conhecido ou quando, não obstante seja este identificado, não disponha de recursos financeiros para responder civilmente, o que não é raro de acontecer. Para tais situações, surge uma solução que vai ao encontro dos interesses das vítimas: a instituição de fundos estatais para indenização de vítimas de crime. ${ }^{136}$

A instituição pioneira de tais fundos, segundo MANZANERA, é atribuída à França, que em 1951 criou um fundo de garantia em prol das vítimas nos casos em que o responsável pelo dano causado por um veículo automotor fosse desconhecido ou insolvente, total ou parcialmente. Tais fundos posteriormente se disseminaram por outros países, como Itália, Bélgica, Nova Zelândia, Inglaterra, alguns Estados norte-americanos, Canadá, Áustria, Dinamarca, Finlândia, Holanda, Luxemburgo, Japão, Noruega, Alemanha, Suécia e México. ${ }^{137}$

A existência desses fundos públicos encontra-se prevista na Declaração dos Princípios Básicos de Justiça Relativos às Vítimas da Criminalidade e de Abuso de Poder,

\footnotetext{
${ }^{136}$ Quanto à indenização levada a cabo por tais fundos, parece preponderar a ideia de que sejam dotados de caráter subsidiário, sendo a obrigação inicialmente atribuível ao autor da infração penal: "Tem prevalecido, no entanto, a compreensão de que essa intervenção estatal é de natureza subsidiária, ou seja, o conjunto da sociedade (ideia de solidariedade social), só é convocado a colaborar quando o autor, de modo induvidoso, não dispuser de bens ou recursos suficientes à compensação da vítima, de modo que, de regra, a reparação da vítima deve permanecer como obrigação a cargo do delinquente". (destaques do autor). (CÂMARA, Guilherme Costa. Programa de política criminal orientado para a vítima do crime. São Paulo: Editora Revista dos Tribunais; Coimbra: Coimbra Editora, 2008, p. 209-210).

${ }^{137}$ Para uma análise mais detida, cf. MANZANERA, Luis Rodriguez. Victimología. 12. ed. Cidade do México: Porrúa, 2010, p. 407-409.
} 
da ONU (Resolução 40/34, de 29.11.1985), em seu anexo, arts. 12 e 13, ${ }^{138}$ bem como na Diretiva 2004/80/CE, do Conselho da União Europeia, de 29 de abril de 2004, que estabelece orientações para os regimes nacionais de indenização e para o acesso a indenização em situações transfronteiras, asseverando, em seu art. $2^{\circ}$, que "a indemnização deve ser paga pela autoridade competente do Estado-Membro em cujo território o crime foi praticado."

Um aspecto que chama a atenção refere-se ao fundamento da existência de tais fundos, que parece compatibilizar-se mais com a ideia de solidariedade social ou coletiva. $^{139}$

No Brasil, a Constituição Federal de 1988, em seu art. 245, prevê a instituição de fundos públicos para indenização em prol das vítimas, nos seguintes termos: "A lei disporá sobre as hipóteses e condições em que o Poder Público dará assistência aos herdeiros e dependentes carentes de pessoas vitimadas por crime doloso, sem prejuízo da responsabilidade civil do autor do ilícito", que parece inspirar-se na ideia de solidariedade social ou coletiva, como ocorre em relação ao seguro do DPVAT.

Tal dispositivo constitucional ainda se encontra sem regulamentação legal, ${ }^{140}$ de modo que o ordenamento jurídico parece somente contar com o FUNPEN (Fundo Penitenciário Nacional), criado pela Lei Complementar n. 79/94, o qual não se destina exclusivamente a indenização das vítimas, sendo esta apenas uma de suas múltiplas finalidades, conforme prevê o art. $3^{\circ}$ daquele diploma legal. ${ }^{141}$

138 “12. Quando não seja possível obter do delinquente ou de outras fontes uma indemnização completa, os Estados devem procurar assegurar uma indemnização financeira: a) Às vítimas que tenham sofrido um dano corporal ou um atentado importante à sua integridade física ou mental, como consequência de actos criminosos graves; b) À família, em particular às pessoas a cargo das pessoas que tenham falecido ou que tenham sido atingidas por incapacidade física ou mental como consequência da vitimização. 13. Será incentivado o estabelecimento, o reforço e a expansão de fundos nacionais de indemnização às vítimas. De acordo com as necessidades, poderão estabelecer-se outros fundos com tal objectivo, nomeadamente nos casos em que o Estado de nacionalidade da vítima não esteja em condições de indemnizá-la pelo dano sofrido."

139 " [...] a indenização não transforma a reparação do dano decorrente do delito em um tipo de responsabilidade estatal decorrente de um ato omissivo do Estado, mas se funda no conceito de solidariedade social, o que faz com que aos fundos estatais se aliem outros fundos especiais de indenização baseados na corresponsabilidade da comunidade [...], como aqueles que preveem uma indenização na hipótese de acidentes de trânsito." (BARROS, Flaviane de Magalhães. A participação da vítima no processo penal. Rio de Janeiro: Lumen Juris, 2008, p. 134).

${ }^{140}$ Existe um projeto de lei que trata dessa regulamentação, o PLS 269/2003, que cria o FUNAV (Fundo Nacional de Assistencia às Vítimas de Crimes Violentos), o qual obteve aprovação junto ao Senado Federal, já tendo sido remetido à Câmara dos Deputados, onde aguarda deliberação. Disponível em: $<$ http://www.senado.gov.br/atividade/materia/getPDF.asp?t=68877\&tp=1>. Acesso em: 23 dez. 2011.

141 "Art. $3^{\circ}$. Os recursos do FUNPEN serão aplicados em: I - construção, reforma, ampliação e aprimoramento de estabelecimentos penais; II - manutenção dos serviços penitenciários; III - formação, aperfeiçoamento e especialização do serviço penitenciário; IV - aquisição de material permanente, equipamentos e veículos especializados, imprescindíveis ao funcionamento dos estabelecimentos penais; V - 
Não se deve olvidar que a ideia de um fundo público pró-vítimas ganhará um maior reforço com a aprovação definitiva do projeto do Código de Processo Penal que, em seu art. 91, inciso XIV, prevê, dentre os direitos da vítima, "o direito à assistência financeira nas hipóteses e condições da lei por parte do Poder Público.”

Por fim, ainda carece de previsão na legislação nacional, vigente ou projetada, a possibilidade de reembolso de despesas imediatas, tidas pela vítima em razão do processo, como por exemplo, as despesas de transporte para comparecer a depoimento ou para submeter-se a exame de corpo de delito ou a outras perícias, que já conta na legislação alienígena como disciplinamento específico. ${ }^{142}$

\subsection{DIREITO DA VÍTIMA À INFORMAÇÃO}

\subsubsection{O direito da vítima à informação no atual processo penal brasileiro}

A Constituição Federal de 1988 assegura a todos, em seu art. 5º, inciso XIV, o acesso à informação, mais especificamente, a liberdade de informação, que "compreende a procura, o acesso, o recebimento e a difusão de informações ou ideias, por qualquer meio, e sem dependência de censura, respondendo cada qual pelos abusos que cometer."143

CUNHA JÚNIOR faz a distinção de três aspectos em relação a tal liberdade: o

implantação de medidas pedagógicas relacionadas ao trabalho profissionalizante do preso e do internado; VI - formação educacional e cultural do preso e do internado; VII - elaboração e execução de projetos voltados à reinserção social de presos, internados e egressos; VIII - programas de assistência jurídica aos presos e internados carentes; IX - programa de assistência às vítimas de crime; $X$ - programa de assistência aos dependentes de presos e internados; XI - participação de representantes oficiais em eventos científicos sobre matéria penal, penitenciária ou criminológica, realizados no Brasil ou no exterior; XII - publicações e programas de pesquisa científica na área penal, penitenciária ou criminológica; XIII - custos de sua própria gestão, excetuando-se despesas de pessoal relativas a servidores públicos já remunerados pelos cofres públicos; XIV - manutenção de casas de abrigo destinadas a acolher vítimas de violência doméstica. (Incluído pela Lei Complementar n ${ }^{\circ} 119$, de 2005)". (destaques nossos).

${ }^{142} \mathrm{O}$ art. 79, "b", do Codigo de Proceso Penal de la Nación, da Argetina, prevê, dentre os direitos das vítimas, o direito "al sufragio de los gastos de traslado al lugar donde la autoridad competente designe", ao qual acresce também o item "e", que prevê o direito, "cuando se tratare de persona mayor de setenta (70) años, mujer embarazada o enfermo grave a cumplir el acto procesal en el lugar de su residencia; tal circunstancia deberá ser comunicada a la autoridad competente con la debida anticipación".

${ }^{143}$ SILVA, José Afonso da. Curso de direito constitucional positivo. 16 ed. São Paulo: Malheiros, 1999, p. 249 . 
direito de informar, o direito de se informar e o direito de ser informado, ${ }^{144}$ interessando mais aos objetivos desta exposição os dois últimos.

Para o referido autor, o direito de se informar "corresponde à faculdade de o indivíduo buscar as informações pretendidas sem quaisquer obstáculos”, ao passo que o direito de ser informado "equivale à faculdade de ser mantido completa e adequadamente informado", sendo "restrito aos assuntos ligados às atividades do poder público", citando o autor o disposto no inciso XXXIII, do art. $5^{\circ}$, da Constituição Federal de 1988, que enuncia o direito de todos de "receber dos órgãos públicos informações de seu interesse particular, ou de interesse coletivo ou geral".

No caso dos processos judiciais, a liberdade de informação encontra amparo especial no art. 93, inciso IX, da Constituição Cidadã, que assegura a publicidade dos atos processuais. $^{145}$

Não obstante essas disposições constitucionais, na ausência de regras específicas que tutelassem esse direito das vítimas de infração penal à informação, seu exercício mostrava-se, em verdade, inviabilizado, de modo que o processo penal transcorria, na prática, do início ao fim, sem que aquela tomasse qualquer ciência dos atos processuais praticados. A bem da verdade, o único ato processual do qual a vítima tinha ciência era da audiência de instrução, desde que fosse arrolada para depor, a depender da vontade das partes em ouvi-la. E mesmo assim, tal ciência se destinava tão-somente a obter as informações sobre o caso por seu depoimento, ou seja, tinha por finalidade a produção de elementos de prova e não o asseguramento do direito à informação por parte da vítima, reduzindo-se esta a um mero objeto do processo.

É verdade que o olvidamento processual da vítima em processos instaurados a partir de ação penal de iniciativa pública sofre considerável atenuação ${ }^{146}$ quando aquela se habilita nos autos como assistente (Código de Processo Penal, arts. 268 a 273). Contudo, perceba-se que o direito à informação não é oportunizado àquele que é simplesmente vítima, fazendo-se necessário a esta que, para ter reconhecido tal direito à informação,

${ }^{144}$ CUNHA JÚNIOR, Dirley da. Curso de direito constitucional. 2 ed. rev. amp. atual. Salvador: Jus Podium, 2008, p. 649-650.

${ }_{145}$ "IX - todos os julgamentos dos órgãos do Poder Judiciário serão públicos, e fundamentadas todas as decisões, sob pena de nulidade, podendo a lei limitar a presença, em determinados atos, às próprias partes e a seus advogados, ou somente a estes, em casos nos quais a preservação do direito à intimidade do interessado no sigilo não prejudique o interesse público à informação.” (redação conferida pela EC n. 45/04).

${ }^{146}$ Fala-se aqui em considerável atenuação, pois não se pode falar que a habilitação como assistente garanta integralmente à vítima o direito à informação. De fato, a habilitação como assistente somente pode dar-se após o oferecimento da denúncia pelo Ministério Público, de modo que durante toda a investigação preliminar, o direito à informação da vítima permanece a descoberto, impossibilitada que está de habilitar-se formalmente no feito. 
constitua advogado a fim de ingressar nos autos como assistente, tarefa para a qual nem todos encontram estímulo em face da necessidade de pagamento de honorários advocatícios e da precariedade das Defensorias Públicas dos Estados e da União.

Curioso é que a própria possibilidade, em si, de habilitação da vítima na condição de assistente, não lhe é cientificada, não existindo qualquer dispositivo legal que estabeleça tal dever por partes das autoridades, o que dificulta ainda mais a habilitação da vítima como assistente e sua decorrente investidura no direito à informação no processo penal que daí pode decorrer.

Somente com o advento da Lei n. 11.690/2008, que alterou o art. 201 do Código de Processo Penal, é que se começou a implementar o direito à informação para as vítimas no processo. Assim, o mencionado dispositivo legal ganhou o $\S 2^{\circ}$, o qual enuncia que "o ofendido será comunicado dos atos processuais relativos ao ingresso e à saída do acusado da prisão, à designação de data para audiência e à sentença e respectivos acórdãos que a mantenham ou modifiquem", bem como o $\S 3^{\circ}$, que assegura que "as comunicações ao ofendido deverão ser feitas no endereço por ele indicado, admitindo-se, por opção do ofendido, o uso de meio eletrônico".

Dessarte, basicamente, a vítima, independentemente de sua habilitação como assistente, passa a contar com o direito de ser informada, pessoalmente ou por meio eletrônico - conforme preferir - acerca dos seguintes atos: a) entrada e saída do acusado da prisão; b) despacho que designar data para audiência; c) sentença e respectivo acórdão que a mantenha ou modifique.

Essa inovação legislativa, embora talvez ainda demore a ser incorporada na praxe forense, poderá constituir o germe para um desenvolvimento mais fecundo do direito sob análise.

\subsubsection{Novas perspectivas sobre o direito da vítima à informação}

O direito à informação - deve-se enfatizar - constitui um direito-chave para a tutela da vítima. Todos os demais direitos, aqui classificados como direito à proteção, direito à participação e direito à solução consensual do processo, dependem, para sua efetivação, de que sejam devidamente informados à vítima, oportunizando-se, assim, seu exercício. 
Dada essa importância, o direito em pauta conta com previsão generalizada em documentos internacionais e nas diversas legislações nacionais.

Dessarte, o art. $6^{\circ}$, do anexo da Declaração dos Princípios Básicos de Justiça Relativos às Vítimas da Criminalidade e de Abuso de Poder (Resolução 40/34, de 29.11.1985) enuncia que se deve informar às vítimas "da sua função e das possibilidades de recurso abertas, das datas e da marcha dos processos e da decisão das suas causas, especialmente quando se trate de crimes graves e quando tenham pedido essas informações".

A Decisão-quadro do Conselho da União Europeia Relativo ao Estatuto da Vítima em Processo Penal, de 15.03.2001, por sua vez, mostra-se exemplar na tutela desse direito. Em seu art. $4^{\circ}$., assegura à vítima "desde seu primeiro contacto com as autoridades competentes para a aplicação da lei, o acesso às informações que forem relevantes para a proteção de seus interesses".

Essas informações seriam, pelo menos, segundo referida diretiva europeia, as seguintes (4.1): a) o tipo de serviços ou de organizações a que pode dirigir-se para obter apoio; b) o tipo de apoio que pode receber; c) onde e como pode a vítima apresentar queixa; d) quais são os procedimentos subsequentes à queixa e qual o papel da vítima no âmbito dos mesmos; e) como e em que termos poderá a vítima obter proteção; f) em que medida e em que condições a vítima terá acesso a aconselhamento jurídico ou apoio judiciário (se tiver direito), ou a qualquer outra forma de aconselhamento; g) quais são os requisitos que regem o direito da vítima a indenização; h) se for residente noutro Estado, que mecanismos especiais de defesa dos seus interesses pode utilizar.

Referida Decisão-quadro, em seu art. 4.2, declara que cada Estado-Membro deve assegurar que a vítima seja informada, sempre que manifestar essa vontade: a) do seguimento dado à sua queixa; b) dos elementos pertinentes que lhe permita, em caso de pronúncia, ser inteirada do andamento do processo penal relativo à pessoa pronunciada por fatos que lhe digam respeito, exceto em casos excepcionais que possam prejudicar o bom andamento do processo; c) da sentença do tribunal.

$\mathrm{O}$ art. 4.3, por sua vez, enuncia que os Estados-Membros devem tomar as medidas necessárias para assegurar que, pelo menos nos casos de perigo potencial para a vítima, quando a pessoa pronunciada ou condenada por essa infração seja libertada, se possa decidir informar a vítima, se tal for considerado necessário.

Por fim, conforme o disposto no art. 4.4, o Estado-Membro, na medida em que comunique por sua própria iniciativa as informações a que se referem os arts. 4.2 e o 4.3, 
deve assegurar à vítima o direito de optar por não receber essas informações, salvo se a comunicação das mesmas for obrigatória, nos termos do processo penal aplicável.

Lançando um rápido olhar no direito comparado, pode-se citar como destaque o caso do ordenamento jurídico mexicano, em que a própria Constituição dos Estados Unidos do México assegura aquele que for vítima, em seu art. 20-C, I, o direito de "ser informado de los derechos que en su favor establece la Constitución y, cuando lo solicite, ser informado del desarrollo del procedimiento penal". ${ }^{147}$

Com a finalidade de adaptar-se aos novos comandos constitucionais favoráveis às vítimas de infração penal, previstos no art. 20-C, da Constituição mexicana, o Código Federal de Procedimientos Penales, em 2009, sofreu reformas, passando a contemplar uma variada gama de direitos em prol das vítimas. Assim, em seu art. 3, X, "b", o mencionado Código determina como dever das polícias "informar a la víctima o ofendido sobre los derechos que en su favor establece la Constitución Política de los Estados Unidos Mexicanos".

Referido código federal assegura ainda à vítima os seguintes direitos: a) durante a "averiguación previa": o direito de ser informada sobre os direitos estabelecidos em seu favor pela Constituição e pelo ordenamento jurídico, o direito de ser informada sobre o desenvolvimento da "averiguación previa" e sobre as consequências legais dos atos em que atuar, bem como de ser informada claramente do significado e do alcance jurídico do perdão no caso em que deseje outorgá-lo (art. 141, A, II a IV); b) durante o processo penal propriamente dito, o direito de acesso para informar-se sobre o estado e o avanço do processo em qualquer fase em que se encontre, ressalvando-se a informação que ponha em risco a investigação ou a identidade das pessoas protegidas, o direito de ser informado sobre o desenvolvimento do processo penal e das consequências legais dos atos em que atuar e o de receber, gratuitamente, cópia simples ou autenticada de suas declarações quando o solicite (art. 141, B, I a III). ${ }^{148}$

A legislação nacional argentina também pode ser citada in casu, regulamentando o Codigo de Proceso Penal de la Nación o direito da vítima à informação, ao enunciar: o direito a "ser informado sobre los resultados del acto procesal en el que ha participado" (art. 79, "d"); o direito a "ser informada por la oficina correspondiente acerca de las facultades que puede ejercer en el proceso penal, especialmente la de constituirse en actor civil o tener calidad de querelante" (art. 80, "a"); direito a "ser

\footnotetext{
${ }^{147}$ MANZANERA, Luis Rodriguez. Victimología. 12. ed. Cidade do México: Porrúa, 2010, p. 365.

${ }^{148}$ MANZANERA, Luis Rodriguez. Victimología. 12. ed. Cidade do México: Porrúa, 2010, p. 371.
} 
informada sobre el estado de la causa y la situación del imputado" (art.80, "b"), asegurando-se, em seu art. 81, que "los derechos reconocidos en este capítulo deberán ser enunciados por el órgano judicial competente, al momento de practicar la primera citación de la víctima o del testigo". ${ }^{149}$

Tornando à realidade brasileira, a expectativa é de que o direito da vítima à informação ganhe uma incrementação sob o Código de Processo Penal projetado, já aprovado no Senado Federal e encaminhado à Câmara dos Deputados. Referido projeto amplia o rol de situações reconhecidas expressamente como objeto do direito à informação da vítima, passando a fazer incidir também o direito à informação sobre alguns atos préprocessuais, como a conclusão do inquérito policial e o oferecimento de denúncia (art. 91, inciso V).

Preveem-se, em acréscimo, o direito de obtenção de cópias de peças do inquérito policial e do processo penal, salvo quando, justificadamente, devam permanecer em estrito sigilo (art. 91, inciso VI), o direito de ser orientada quanto ao exercício oportuno do direito de representação, de ação penal subsidiária da pública, de ação civil por danos materiais e morais, da adesão civil à ação penal e da composição dos danos civis para efeito de extinção da punibilidade, nos casos previstos em lei (art. 91, inciso VII), e o direito de peticionar às autoridades públicas para se informar a respeito do andamento e deslinde da investigação ou do processo (art. 91, inciso X).

O projeto, em seu art. 271, assegura, uma vez oferecida a denúncia, e em não havendo indeferimento liminar, que o juiz deverá notificar a vítima para, no prazo de dez (10) dias, promover a adesão civil da imputação penal, possibilitando o exercício efetivo, pela vítima, do sistema de adesão facultativa trazido pelo projeto.

Observe-se que essas novas disposições projetadas, somadas às acrescidas pela reforma do art. 201, do Código de Processo Penal, por força da Lei n. 11.690/08, em muitos pontos, aproximam o ordenamento jurídico brasileiro das avançadas disposições da própria Decisão-quadro do Conselho da União Europeia Relativo ao Estatuto da Vítima em Processo Penal, de 15.03.2001, constituindo um sólido arsenal de proteção ao direito da vítima à informação.

Contudo, a despeito de tais disposições normativas, sobrepõe-se o grande desafio de se garantir a eficácia desses direitos. A enunciação de direitos não pode limitarse a uma declaração de bons propósitos, devendo ser reforçada a contrapartida: o dever

\footnotetext{
${ }^{149}$ ARGENTINA. Código procesal penal de la Nación. Disponível em: <http:www.infoleg.gov.ar/infolegIn ternet/anexos/0-4999/383/texact.htm>. Acesso em: 05 out. 2010.
} 
legal das autoridades em assegurá-los às vítimas. É importante que esse dever legal seja expressamente previsto, recaindo sobre as autoridades dos órgãos do sistema de justiça penal junto às quais a vítima tenha contato (delegados, promotores e juízes). Nesse aspecto, o dever de informação por parte da autoridade policial mostra-se de indiscutível importância, tendo em vista que, via de regra, é à Polícia que a vítima inicialmente pede auxílio, sendo o primeiro órgão estatal que se lhe descortina no sistema de justiça penal.

Em tal sentido, o art. 25, inciso I, do Código Projetado, dispõe que incumbirá ao delegado de polícia "informar a vítima de seus direitos e encaminhá-la, caso seja necessário, aos serviços de saúde e programas assistenciais disponíveis”. A omissão em relação a tal dever - isso precisa ser ressaltado - pode ensejar ao agente público infrator responsabilização penal, administrativa e, eventualmente, de natureza cível (em caráter regressivo).

Por fim, alguns pontos ainda merecem consideração, em se tratando de direito da vítima à informação. $\mathrm{O}$ primeiro ponto refere-se à modificação, já vigente, relativa ao direito de ciência da sentença e fluência do prazo para interposição de respectivo recurso, em se tratando de vítima não habilitada nos autos como assistente.

Explica-se: antes da Lei n. 11.690/08, a vítima somente tinha direito a ser cientificada da sentença caso estivesse habilitada nos autos como assistente. Uma vez intimada, poderia a vítima-assistente exercer seu direito à interposição de recurso, como a apelação, dentro do prazo legal, a saber, de cinco (05) dias, a contar do término in albis do prazo para o Ministério Público (conforme o disposto no art. 598, do Código de Processo Penal e a Súmula n. 448 , do STF $)^{150}$.

$\mathrm{O}$ direito à intimação da sentença, conferido exclusivamente à vítimaassistente, não somente lhe oferecia, assim, a possibilidade de conhecer o teor do referido decisum, mas também lhe assegurava formalmente a oportunidade de interposição de recurso, ainda que em caráter supletivo, servindo tal intimação como referência para a fluência do prazo recursal, bastando-lhe atentar para possível omissão do Ministério Público na interposição do recurso deste. ${ }^{151}$

Situação bem diversa ocorria em relação à vítima não habilitada como

\footnotetext{
${ }^{150}$ A Súmula n. 448, do STF, assim dispõe: “O prazo para o assistente recorrer, supletivamente, começará a correr imediatamente após o transcurso do prazo do Ministério Público".

${ }^{151}$ Sobre a contagem do prazo para o assistente habilitado, LOPES JÚNIOR distingue duas situações: "a) se o assistente (habilitado) é intimado antes do término do prazo recursal do MP, o seu prazo começara a correr imediatamente após o decurso do prazo concedido àquele; b) se o assistente (habilitado) é intimado após o término do prazo recursal do MP, o seu prazo começará a correr no primeiro dia útil subsequente à intimação". (LOPES JÚNIOR, Aury. Direito processual penal e sua conformidade constitucional. 5. ed. rev. atual. Rio de Janeiro: Lumen Juris, 2010, v. 2, p. 541).
} 
assistente. Embora seu direito ao recurso se mostrasse inegável, em face do disposto no CPP, arts. 598 e 584, $\S 1^{\circ}$, ausente o dever de intimação da sentença em relação àquela, a fluência do prazo recursal - quinze (15) dias contados a partir da fluência in albis do prazo para o Ministério Público - dava-se sem que a vítima-não assistente fosse cientificada, de modo que o prazo poderia fluir sem que a vítima tivesse sequer conhecimento de que poderia interpor algum recurso. Cabia-lhe, dessarte, se assim o desejasse, acompanhar por conta própria o trâmite do processo sem qualquer comunicação judicial que lhe servisse de referência.

Tudo isso mudou com o advento da Lei n. 11.690/08, que acrescentou o $\$ 2^{\circ}$ ao art. 201, do Código de Processo Penal (“o ofendido será comunicado dos atos processuais relativos [...] à sentença e respectivos acórdãos que a mantenham ou modifiquem”). Perceba-se que o termo comunicação aqui utilizado precisa ser entendido como equivalente ao ato de intimação da sentença, cujo teor deve ser oportunizado à vítima, independentemente de esta encontrar-se habilitada ou não como assistente nos autos. ${ }^{152}$

Esse direito da vítima, assistente ou não, de ser comunicada (leia-se: intimada) da sentença criminal, tem por condão equiparar as situações anteriormente distintas (vítima-assistentel vítima-não assistente), de modo que, em qualquer caso, a vítima, habilitada como assistente ou não, deverá ser intimada da sentença e servirá tal intimação como referência para a contagem do prazo recursal, cabendo-lhe apenas atentar para a inércia recursal do Ministério Público. ${ }^{153}$

Outra questão interessante que se coloca consiste em saber se o sigilo no processo penal pode ser oposto ao direito à informação da vítima.

Já se analisou neste estudo que o direito à proteção da honra, da imagem e da privacidade pode ensejar a decretação de sigilo em favor da vítima, mas aqui se questiona se poderia o sigilo ser decretado contra a vítima.

A fim de responder a tal questão, impende que se faça a distinção entre publicidade externa e publicidade interna. Conforme MORAES, ${ }^{154}$ a publicidade interna

\footnotetext{
${ }^{152}$ Outra interpretação possível seria a de que a Lei se limitaria a, apenas, determinar que a vítima fosse comunicada de que uma sentença restara prolatada, sem que fosse necessário revelar seu teor, interpretação essa que, além de insuficiente para atender aos interesses da vítima, traria pouca funcionalidade à inovação.

${ }^{153}$ Deve-se observar que o ideal é que a vítima pudesse interpor recursos independentemente do Ministério Público e de sua eventual inércia, de modo que o prazo recursal daquela começasse a fluir já de sua intimação, assunto que será observado posteriormente neste estudo.

${ }^{154}$ MORAES, Maurício Zanoide de. Publicidade e proporcionalidade na persecução penal brasileira. In: FERNANDES, Antônio Scarance; ALMEIDA, José Raul Gavião de; MORAES, Maurício Zanoide de Moares (Coord.). Sigilo no processo penal: eficiência e garantismo. São Paulo: Revista dos Tribunais, 2008, p. 29-55, p. 43.
} 
"se refere àquela garantida às partes, a seus defensores e demais operadores do direito que atuam na persecução penal (policiais, servidores judiciais, peritos - particulares ou públicos etc.)", ao passo que a publicidade externa "é a que se garante aos terceiros estranhos à persecução".

Tratando especificamente das restrições à publicidade, MORAES ${ }^{155}$ afirma que a restrição da publicidade externa limita-se à proteção das pessoas envolvidas na persecução estatal, como é o caso do acusado, da vítima, da testemunha etc., ou à proteção da proficuidade dessa persecução, sem que haja prejuízo para os juridicamente interessados, ao passo que a limitação da publicidade interna "tem o efeito imediato de criar uma desigualdade na persecução, pois somente ocorre para uma parte da persecução, qual seja, o sujeito investigado/acusado, remanescendo irrestrita para os demais atuantes (Polícia Judiciária e Ministério Público)".

De fato, encontrando-se a vítima, em tese, vinculada à persecução penal, independentemente de sua habilitação como assistente, como o prova a faculdade de interposição de recursos pela vítima-não assistente, a publicidade processual em relação à sua pessoa cuida-se da publicidade interna. E em se tratando de publicidade interna, conforme afirmado por MORAES, as restrições somente existem em relação ao "investigado/acusado", em nada afetando os demais atores processuais. Assim, à vítima não pode ser restrita a publicidade dos autos, não se lhe podendo opor segredo.

Nessa mesma linha, para KEHDI, “a vítima [...] deve ter o acesso aos autos assegurado", ${ }^{156}$ e ainda que não atue como querelante ou assistente de acusação, "afigurase possível que a vítima tome conhecimento do conteúdo do inquérito ou do processo, já que está diretamente envolvida nos fatos ali apurados. Isso, contudo, não a desincumbirá do dever de reserva que deve guardar em relação ao que vier a apreender". ${ }^{157}$

Assim, o acesso aos autos do inquérito policial ou do processo - ainda que sob tais autos incida o segredo de justiça - deve ser franqueado à vítima, independentemente de esta constituir-se ou não como assistente, tendo em vista sua condição de sujeito de

\footnotetext{
${ }^{155}$ MORAES, Maurício Zanoide de. Publicidade e proporcionalidade na persecução penal brasileira. In: FERNANDES, Antônio Scarance; ALMEIDA, José Raul Gavião de; MORAES, Maurício Zanoide de Moares (Coord.). Sigilo no processo penal: eficiência e garantismo. São Paulo: Revista dos Tribunais, 2008, p. $29-55$, p. 43.

${ }^{156}$ KEHDI, André Pires de Andrade. O sigilo da ação penal: aspectos gerais. In: FERNANDES, Antônio Scarance; ALMEIDA, José Raul Gavião de; MORAES, Maurício Zanoide de Moares (Coord.). Sigilo no processo penal: eficiência e garantismo. São Paulo: Revista dos Tribunais, 2008, p. 57-95, p. 81.

${ }^{157}$ KEHDI, André Pires de Andrade. O sigilo da ação penal: aspectos gerais. In: FERNANDES, Antônio Scarance; ALMEIDA, José Raul Gavião de; MORAES, Maurício Zanoide de Moares (Coord.). Sigilo no processo penal: eficiência e garantismo. São Paulo: Revista dos Tribunais, 2008, p. 57-95, p. 81.
} 
direitos e sua inegável vinculação com a persecução penal.

No exercício de tal direito, poderá a vítima não somente ter acesso aos autos, diretamente ou por advogado constituído, como também peticionar para a autoridade, solicitando informações sobre o andamento da investigação preliminar e do processo e obter cópias dos autos - no todo ou em parte. ${ }^{158}$

Caso a vítima faça uso das informações sigilosas indevidamente, por exemplo, para atingir a honra do suspeito, investigado ou acusado, deve-se promover sua responsabilização pela prática de eventuais infrações penais e por eventual prejuízo de natureza cível provocado em decorrência de tal conduta.

\footnotetext{
${ }^{158}$ Esses direitos serão realçados com a aprovação do Código projetado, que em seu art. 91, inciso X, prevê o direito de a vítima peticionar às autoridades públicas para se informar a respeito do andamento e deslinde da investigação ou do processo, bem como o direito de obtenção de cópias de peças do inquérito policial e do processo penal, em seu art. 91, inciso VI, ressalvando-se a existência de sigilo e devendo tal negativa ser fundamentada. Perceba-se que, nesse caso, não se proíbe o acesso propriamente dito da vítima aos autos, mas tão-somente a extração de cópias da autuação sob sigilo.
} 


\section{DIREITO DA VÍTIMA À PARTICIPAÇÃO}

\subsection{OBSERVAÇÕES INICIAIS}

Preliminarmente, cumpre registrar que a presente análise do direito da vítima à participação, restringe-se ao âmbito dos processos instaurados a partir de ação penal de iniciativa pública. Isso porque nos processos instaurados a partir de ação penal de iniciativa privada, o ordenamento jurídico já dispensa à vítima tratamento de sujeito de direitos, na condição de parte autora, conferindo-lhe inegável protagonismo, bem como ampla disponibilidade sobre a pretensão acusatória, como o provam os institutos da renúncia, do perdão e da composição civil de danos, esta trazida pela sistemática da Lei n. 9.099/95.

De fato, é no processo instaurado pela ação penal de iniciativa pública que à vítima se atribui tradicionalmente uma participação de somenos importância, o que pode ensejar o fenômeno da vitimização secundária. Desse modo, o papel da vítima nesse processo fica a merecer uma nova perspectivação.

A fim de proporcionar uma análise mais didática sobre o tema em questão, propõe-se o desmembramento do direito à participação quanto a seus aspectos mais importantes, no que se toma o modelo de FERNANDES, que cita as modalidades de "condicionamento à manifestação da vítima", "controle sobre a acusação pública" e "concurso ou cooperação", agregando-se aqui, ainda, a "reparação de danos civis" e a "participação da vítima na produção de elementos probatórios". ${ }^{159}$

Neste capítulo serão abordadas tais modalidades, partindo-se, em cada caso, ou seja, em cada modalidade do direito à participação, de uma visão sobre sua configuração no atual processo penal brasileiro, passando às novas perspectivas, em que primeiramente se analisarão documentos e normas internacionais, dispositivos referentes à matéria, constantes no projeto de Código de Processo Penal que tramita no Congresso Nacional, bem como, em alguns casos, ordenamentos jurídicos selecionados de direito comparado.

Após, lançar-se-á ao delineamento de um aperfeiçoamento de cada modalidade

159 FERNANDES faz a distinção entre a) interesses penais, aos quais atribui as modalidades de condicionamento à manifestação da vítima, controle sobre a acusação pública e concurso ou cooperação; b) interesses civis, nos quais insere a reparação de danos; e c) outros papéis da vítima, em que destaca a relação entre a vítima e a prova. (FERNANDES, Antônio Scarance. O papel da vítima no processo criminal. São Paulo: Malheiros, 1995, passim). 
de direito à participação no sistema processual penal nacional.

No tocante à participação da vítima na produção de elementos probatórios, depois de uma breve introdução, em que se discorrerá sobre noções de prova, será explorada dita modalidade, dando-se ênfase à possibilidade de recusa da vítima, e seus limites, em participar dessa produção probatória.

Por fim, deve-se adiantar que a modalidade de direito da vítima à participação, denominada aqui de concurso (ou cooperação), em razão de sua maior complexidade e da importância para o presente trabalho, dos questionamentos que lhe são decorrentes, não será objeto de abordagem neste capítulo, merecendo tratamento particularizado em capítulo próprio, seguinte a este, dada a necessidade de maior aprofundamento.

\subsection{CONDICIONAMENTO À MANIFESTAÇÃO DA VÍTIMA}

\subsubsection{O condicionamento no atual processo penal brasileiro}

O CPP, em seu art. 24, prevê a ação penal de iniciativa pública condicionada à representação. Consiste essa representação na manifestação de vontade do ofendido para autorizar a persecução penal, sendo necessária não somente como condição para o oferecimento de eventual denúncia, mas também para a anterior instauração de inquérito policial sobre os fatos (art. $5^{\circ}, \S^{\circ}$, do Código de Processo Penal), ${ }^{160}$ constituindo-se verdadeira condição de procedibilidade.

Segundo FERNANDES, cuida-se a representação de "direito subjetivo individual, enquadrável na categoria dos direitos cívicos, pois impõe ao Estado a obrigação de acusar se presentes os requisitos necessários para o oferecimento da denúncia”. ${ }^{161}$

\footnotetext{
${ }^{160}$ No direito comparado FERNANDES, cita institutos semelhantes ao da representação brasileira, que caracteriza a ação penal de iniciativa pública condicionada à representação, como: instancia privada, na Argentina, Costa Rica, Paraguai e Espanha, a querela e a istanza di procedimento, na Itália, Antrag, na Alemanha, plainte, na França, Bélgica e Suíça, previa denuncia, no Chile, querella necesaria, no México, e queixa ou denúncia, em Portugal (no caso de delitos semi-públicos). Todos esses institutos, não obstante suas variações, apresentariam, em comum, a necessidade de condicionar a ação penal de iniciativa pública à vontade da vítima. (FERNANDES, Antônio Scarance. O papel da vítima no processo criminal. São Paulo: Malheiros, 1995, p. 91-92).

${ }^{161}$ FERNANDES, Antônio Scarance. O papel da vítima no processo criminal. São Paulo: Malheiros, 1995, p. 96.
} 
As razões que tradicionalmente fundamentam a existência de ações penais de iniciativa pública condicionadas à vontade da vítima podem ser agrupadas, segundo FERNANDES, em principais e secundárias. ${ }^{162}$

Como principais, podem ser citadas: resguardo da privacidade e da intimidade da vítima ${ }^{163}$ e pouca gravidade do delito praticado ${ }^{164}$; como secundárias, dependência da realização de prova à colaboração da vítima, prevalência do interesse na reparação civil sobre o interesse na punição criminal e a conveniência de evitar o enrijecimento da hostilidade entre pessoas ligadas por interesses comuns.

Ainda sobre as razões que fundamentam o instituto da representação, pode-se afirmar que FERRAJOLI, quando trata das condições objetivas de proceder, aborda o condicionamento da ação penal - o qual identifica como um "resíduo de ação privada" -, prevendo dois critérios para sua eleição: a disponibilidade do bem jurídico tutelado, citando como exemplar o caso de bens patrimoniais privados, e a tutela da autonomia e do interesse à privacidade da parte ofendida, que poderia restar violada por um processo público, como o processo penal. ${ }^{165}$

$\mathrm{O}$ ato de representar pode ser exercido pela própria vítima, pessoalmente ou por procurador com poderes especiais, e, no caso da morte daquela ou declaração judicial de sua ausência, por seu cônjuge, ascendente, descendente ou irmão (Código de Processo Penal, art. $\left.24, \S 1^{\circ}\right)$; em se tratando de vítima menor de dezoito (18) anos de idade, o

${ }^{162}$ FERNANDES, Antônio Scarance. O papel da vítima no processo criminal. São Paulo: Malheiros, 1995, p. 93.

${ }_{163}$ Nesse ponto, percebe-se a particular preocupação com a pessoa da vítima, que pode preferir a não intervenção penal do Estado em face de eventual strepitus iudicii. Para OLIVEIRA, "Trata-se de proteção da vítima de determinados crimes contra os deletérios efeitos que, eventualmente, podem vir a ser causados pela divulgação pública do fato. Por isso, em razão do que a doutrina convencionou chamar de strepitus iudicii (escândalo provocado pelo ajuizamento da ação penal), reserva-se a ela o juízo de oportunidade e conveniência da instauração da ação penal, com o objetivo de evitar a produção de novos danos em seu patrimônio - moral, social, psicológico etc. - diante de possível repercussão negativa trazida pelo conhecimento generalizado do fato criminoso". (OLIVEIRA, Eugênio Pacelli. Curso de processo penal. 11. ed. Rio de Janeiro: Lumen Juris, 2009. p. 121). Cf. também: TUCCI, Rogério Lauria. Teoria do direito processual penal: jurisdição, ação e processo penal (estudo sistemático). São Paulo: Revista dos Tribunais, 2003, p. 125.

${ }^{164}$ Deve-se assentar que o critério da pouca gravidade do delito cuida-se de um dos critérios a ser levado em consideração, não sendo, por si, determinante. Assim, na legislação penal brasileira, por exemplo, há infrações penais de maior gravidade que pedem a representação, como é o caso dos crimes contra a liberdade sexual, desde que não praticados contra menor de 18 anos ou vulnerável, o que torna a ação penal incondicionada (Código Penal, art. 225, com redação conferida pela Lei n. 12.015/09); por outro lado, há infrações penais de menor gravidade que ensejam ação penal de iniciativa pública incondicionada, como é o caso da contravenção penal de vias de fato (Lei das Contravenções Penais, art. 21).

${ }^{165}$ FERRAJOLI, Luigi. Direito e razão: teoria do garantismo penal. Tradução de Ana Paulo Zomer, Fauzi Hassan Choukr, Juarez Tavares e Luiz Flávio Gomes. São Paulo: Revista dos Tribunais, 2002, p. 458-459. 
representante legal da vítima é que deverá fazer a representação; ${ }^{166}$ caso a vítima tenha idade maior de dezoito (18) anos, ainda que menor de vinte e um (21) anos, já dispõe de capacidade civil plena, conforme o novo Código Civil, tendo legitimidade exclusiva para apresentar representação, afastando-se, assim, a possibilidade de legitimidade concorrente com o representante legal, anteriormente aventada. ${ }^{167}$

A representação, que deve referir-se ao fato que constitui, em tese, infração penal, deverá ser encaminhada ao juiz, ao Ministério Público ou à Polícia, dentro do prazo decadencial de seis (06) meses, contado a partir da ciência, pela vítima, do autor do fato; quanto à forma da representação não se impõe maior rigor, podendo ser ofertada oralmente ou por escrito, importando apenas que seja manifestada a vontade da vítima em detrimento de formalidades. ${ }^{168}$

Admite-se, na própria lei (Código de Processo Penal, art. 25), que a representação ofertada seja posteriormente retratada pela vítima. Quanto à possibilidade de retratação da retratação, parece prevalecer o entendimento de que seja possível, embora não haja unanimidade a respeito. ${ }^{169}$

Esse mesmo art. 25, contudo, fixa um prazo máximo para a retratação (“a representação será irretratável, depois de oferecida a denúncia"). Assim, a retratação somente será cabível antes da entrega (protocolização), pelo Ministério Público, da denúncia (petição inicial da ação penal de iniciativa pública) junto ao setor ou órgão competente do Poder Judiciário (secretaria da Vara Criminal, setor de protocolo etc.).

Essa fixação de um prazo máximo para retratação parece ter por objetivo evitar que a persecução penal esteja na dependência da vontade da vítima por tempo mais dilatado, restringindo a Lei esse estado de dependência à vontade da vítima à fase préprocessual (até o oferecimento da denúncia). Todavia, essa limitação legal, prevista nos

\footnotetext{
${ }^{166}$ Sobre o assunto, LOPES JÚNIOR recorda a Súmula n. 594, do STF, entendendo tratar-se de direito único, mas com dois titulares, de modo que uma vez operada a decadência, estaria fulminado o próprio direito. Assim, destaca o autor as seguintes possibilidades: a) se a vítima menor de idade levar ao conhecimento de seu representante legal a infração penal da qual foi vítima, começa a correr o prazo de seis meses, findo o qual, opera a decadência; b) se não houver essa comunicação, quando a vítima completar 18 anos, inicia-se o prazo decadencial de seis meses. Cf. LOPES JÚNIOR, Aury. Direito processual penal e sua conformidade constitucional. 5. ed. rev. atual. Rio de Janeiro: Lumen Juris, 2010, v. 1, p. 381-382.

${ }^{167}$ LOPES JÚNIOR, Aury. Direito processual penal e sua conformidade constitucional. 5. ed. rev. atual. Rio de Janeiro: Lumen Juris, 2010, v. 1, p. 382.

${ }^{168}$ LOPES JÚNIOR, Aury. Direito processual penal e sua conformidade constitucional. 5. ed. rev. atual. Rio de Janeiro: Lumen Juris, 2010, v. 1, p. 385.

${ }^{169}$ Sobre a possibilidade de retratação da retratação, FERNANDES comunga desse entendimento, elencando também outros autores que o desposam, como DAMÁSIO DE JESUS, PEDROSO e MIRABETE. Cita, ainda, autores que defendem a impossibilidade dessa retratação como FREDERICO MARQUES e TOURINHO FILHO. (FERNANDES, Antônio Scarance. O papel da vítima no processo criminal. São Paulo: Malheiros, 1995, p. 103). Cf. também: LOPES JÚNIOR, Aury. Direito processual penal e sua conformidade constitucional. 5. ed. rev. atual. Rio de Janeiro: Lumen Juris, 2010, v. 1, p. 386.
} 
dispositivos originais do Código de 1941, vai de encontro ao movimento vitimológico, que preza justamente pela valoração da vontade da vítima, devendo-se questionar se esse termo final não pode ser fincado a posteriori, na fase processual, de modo, inclusive, a permitirse a retratação da vítima até o momento anterior à prolação da sentença, concedendo-se, dessarte, maior respeito à vontade da vítima.

De modo geral, pode-se afirmar que a ação penal de iniciativa pública condicionada à representação traz grandes vantagens, quer para sociedade em geral, quer para a vítima em especial. Para a sociedade, visto que, em havendo indiscutível interesse público em questão, uma vez exercido o direito de representação, aquela não fica adstrita ao juízo de oportunidade do particular, próprio da ação de iniciativa privada, sendo a condição de autor desempenhada pelo Ministério Público, representante da própria sociedade; para a vítima, as vantagens também são manifestas, pois que tem respeitada sua vontade na instauração ou não de inquérito policial e de eventual processo penal, além de não precisar arcar com os custos e ônus de instauração de um processo e de seu trâmite.

Essas notáveis vantagens ensejam um questionamento sobre a possibilidade de ampliação do rol das hipóteses em que seja cabível a representação, levando BARROS a sugerir essa ampliação, constituindo tal providência como estímulo para evitar a sobrevitimização. ${ }^{170}$

Um importante passo, nesse sentido, foi dado pelo art. 88, da Lei n. 9.099/95, que instituiu o microssistema dos Juizados Especiais Criminais, o qual prevê a exigência de representação para crimes de lesão corporal leve e lesão corporal culposa, não se olvidando ainda que a Lei n. 12.015/2009 erigiu, a regra geral, o condicionamento à manifestação da vítima nos crimes contra a liberdade sexual (Código Penal, art. 225), suprimindo a figura da ação penal privada nessa matéria. ${ }^{171}$

Um passo mais importante ainda seria dado se o legislador estendesse o instituto da representação aos crimes patrimoniais, cometidos sem violência ou grave ameaça, dada a disponibilidade do bem jurídico em questão (o patrimônio particular).

Não obstante os benefícios trazidos pela representação e por uma estratégia que permitisse sua maior disseminação no ordenamento jurídico, o condicionamento da ação

${ }^{170}$ BARROS, Flaviane de Magalhães. A participação da vítima no processo penal. Rio de Janeiro: Lumen Juris, 2008, p. 85.

171 “Os crimes previstos nos arts. 213 a 218-B tornaram-se delitos de ação penal pública condicionada à representação (art. 225, caput). Quando a vítima for menor de 18 anos ou pessoa vulnerável [...], a ação será pública incondicionada (parágrafo único). A Lei n. 12.015/2009, portanto, alterou o regime jurídico da ação penal nesses crimes, pois antes de seu advento, procediam-se, via de regra, mediante queixa-crime". (destaques do autor). (ESTEFAM, André. Crimes sexuais: comentários à Lei n. 12.015/2009. São Paulo: Saraiva, 2009, p. 22-23) 
penal recentemente sofreu uma restrição, a nosso ver, excessiva.

A Lei n. 11.340/06, que permitia, em situações de violência doméstica, o oferecimento de representação pela vítima, bem como a possibilidade de sua retratação (em audiência judicial para tal fim), teve seu art. 16 julgado inconstitucional pelo Supremo Tribunal Federal, quando da análise da ADI n. 4424, ajuizada pela Procuradoria-Geral da República. Em tal julgamento, a Corte Constitucional brasileira assentou entendimento pela natureza incondicionada da ação penal em caso de crime de lesão, pouco importando a extensão desta, praticado contra a mulher no ambiente doméstico. ${ }^{172}$

Essa advertência aqui registrada mostra-se relevante não somente para evitar que o ordenamento jurídico brasileiro se desenvolva na contramão do movimento vitimológico, atentando contra a vontade da vítima, como também para evitar que seja injustamente afastada, em prejuízo do suposto autor da infração penal, uma condição de procedibilidade que deveria lhe beneficiar.

\subsubsection{Novas perspectivas}

Dada a relevância e as vantagens do condicionamento para os fins vitimológicos, anotou-se, no item anterior, que um importante passo seria dado se o legislador estendesse a representação aos crimes patrimoniais, cometidos sem violência ou grave ameaça, dada a disponibilidade do bem jurídico em questão (o patrimônio particular). ${ }^{173}$

Atenta a essa possibilidade, a comissão de juristas encarregada de elaborar o novo Código de Processo Penal (PLS n. 156/09), tecendo críticas à existência, no ordenamento jurídico brasileiro, da ação penal de iniciativa privada principal, defendeu a

\footnotetext{
${ }^{172}$ A decisão, prolatada em 09.02.2012 e publicada em diário oficial (DJE/DOU) na data de 17.02.2012, desperta polêmica, pois pode ensejar uma persecução penal indeclinável em situações em que a própria vítima tenha por desnecessária uma reação estatal, podendo mesmo fomentar instabilidade e novas discórdias em um ambiente doméstico já pacificado.

${ }^{173}$ A comentar sobre extensão do condicionamento aos crimes de lesão corporal leve e culposa, operada pela Lei n. 9.099/95, TOURINHO FILHO já mencionava a possibilidade de um maior alargamento do instituto: "A Lei n. 9.099/95, acolhendo antiga aspiração da doutrina, no artigo sob comentário, subordinou o exercício da ação penal, nos crimes de lesão corporal leve e culposa, à representação. Aliás, a nosso ver, o legislador devia ter estendido a exigência a todos os crimes contra o patrimônio, ressalvados os cometidos com violência e contra incapazes, à semelhança do que ocorre nas hipóteses previstas no art. 182 do CP". (TOURINHO FILHO, Fernando da Costa. Comentários à lei dos juizados especiais criminais. 7. ed. São Paulo: Saraiva, 2010, p. 213).
} 
ampliação do instituto da representação para tais situações. ${ }^{174}$

Assim, o art. 46, caput, do PLS 156/09, ${ }^{175}$ anuncia o condicionamento da

acusação penal, pela representação, para os crimes de falência e os crimes contra o

${ }^{174}$ Cf. na íntegra: "Em um sistema acusatório público, a titularidade da ação penal é atribuída a um órgão que represente os interesses de igual natureza, tal como ocorre na previsão do art. 129, I, da Constituição, que assegura ao Ministério Público a promoção, privativa, da ação penal pública, nos termos da lei. Evidentemente, não há qualquer incompatibilidade entre o aludido modelo processual e a existência de uma ação penal, privativa, substitutiva ou subsidiária, de iniciativa do particular. Portugal, Alemanha e Espanha, por exemplo, admitem iniciativas privadas na persecução penal. Trata-se, em verdade, de uma questão a ser definida politicamente, segundo a compreensão que se tem acerca da natureza e dos objetivos da intervenção estatal penal. A doutrina e a jurisprudência nacionais nem sempre se entenderam a respeito de tais questões. Quais seriam as justificativas para a adoção de uma ação penal privativa do particular? Seria possível classificar os delitos, segundo o respectivo interesse na persecução, em públicos, semi-públicos e privados? O estágio atual de desenvolvimento do Direito Penal aponta em direção contrária a uma empreitada em semelhantes bases conceituais. Basta atentar para as reflexões e investigações mais recentes ao nível da política criminal, e já também no âmbito da própria dogmática, no que se refere às bases de interpretação, todas no sentido de um minimalismo interventivo, justificado apenas para a proteção penal dos direitos fundamentais, contra ações e condutas especialmente graves. Nesse contexto, não nos parece haver lugar para uma ação penal que esteja à disposição dos interesses e motivações do particular, ainda que seja a vítima. Eventual necessidade de aplicação de sanção penal somente se legitima no interesse público. O modelo processual atualmente em vigor ignora completamente essa realidade, deixando em mãos da vítima, não só a iniciativa da ação, mas a completa disposição da intervenção estatal criminal. A justificativa do escândalo do processo, normalmente alardeada em latim, não parece suficiente para justificar a ação privada. Se o problema é a necessidade de proteção da intimidade da vítima em relação à publicidade do fato, basta condicionar o exercício da ação pública à autorização dela. Exatamente como faz o anteprojeto, que, a seu turno, preserva o controle da morosidade do poder público, por meio da ação penal subsidiária da pública, de iniciativa da vítima. Essa, sim, como verdadeiro direito, constitucional, de ação. Se, de outra sorte, a justificativa repousa na maior eficiência do particular na defesa do bem jurídico atingido, também não há razão para a disponibilidade da ação penal instaurada, como ocorre atualmente pelo perdão ou pela perempção. Há exemplo nacional eloquente: proposta a ação privada no crime de estupro, quando praticado sem violência real, a morte da vítima sem deixar sucessores processuais implica a perempção da ação penal, independentemente de se tratar de delito de alta reprovabilidade, frequentemente incluído entre os hediondos. Ao que parece, então, restaria à ação privada a relevante missão de redução do espectro difuso da intervenção penal, redimensionando a questão para a individualidade do conflito, abrindo as portas para o ingresso de um modelo restaurativo da instância penal. Há inegável tendência na diminuição ou contenção responsável da pena privativa da liberdade, em razão dos malefícios evidentes de sua aplicação e execução, sobretudo em sistemas penitenciários incapazes de respeitar condições mínimas de existência humanamente digna. Em consequência, passou-se a adotar, aqui e mundo afora, medidas alternativas ao cárcere, quando nada por razões utilitaristas: a redução na reprodução da violência, incontida nos estabelecimentos prisionais. Mas, nesse quadro, não só a pena ou sanção pública se apresenta como alternativa. A recomposição dos danos e a conciliação dos envolvidos pode se revelar ainda mais proveitosa e eficiente, ao menos da perspectiva da pacificação dos espíritos e da consciência coletiva da eficácia normativa. O anteprojeto busca cumprir essa missão, instituindo a possibilidade de composição civil dos danos, com efeitos de extinção da punibilidade no curso do processo, em relação a crimes patrimoniais, praticados sem violência ou grave ameaça e àqueles de menor repercussão social, no âmbito das infrações de menor potencial ofensivo. Prevê, mais que isso, uma alternativa ao próprio processo, condicionando a ação penal nos aludidos crimes contra o patrimônio, desde que ausente a grave ameaça ou a violência real. Desse modo, substitui-se com vantagem a ação privada e sua incontrolável disponibilidade, por outro modelo mais eficiente: respeita-se a disponibilidade, em relação ao interesse da vítima quanto ao ingresso no sistema de persecução penal - ação pública condicionada mantendo-se, ainda, na ação de natureza pública, a possibilidade de aproximação e conciliação dos envolvidos". (Disponível em: <http://www.camara.gov.br/sileg/integras/393836.pdf>. Acesso em: 24 jan.2012).

${ }^{175}$ Eis a redação final no Senado Federal: “Art. 46. Será pública, condicionada à representação, a ação penal nos crimes de falência e nos crimes contra o patrimônio, material ou imaterial, quando dirigidas exclusivamente contra bens jurídicos do particular e quando praticados sem violência ou grave ameaça contra a pessoa. [...] $\S 3^{\circ}$ Concluídas as investigações nos crimes de ação penal condicionada, a vítima será intimada para, no prazo de trinta dias, ratificar a representação, sob pena de decadência". 
patrimônio, material ou imaterial, quando versem exclusivamente sobre bens jurídicos do particular, e desde que praticados sem violência ou grave ameaça contra a pessoa, exigindo-se, em seu $\S 3^{\circ}$, uma vez concluídas as investigações, a intimação da vítima para ratificar ou não a representação, no prazo de trinta (30) dias, sob pena de decadência.

Em sua redação final no Senado Federal, restou endossado o dispositivo inicial, embora com modificação redacional, que importou na exclusão dos crimes falimentares, suprimindo-se ainda o $\$ 3^{\circ}{ }^{176}$

Indo um pouco além, dada a necessidade de se atentar preponderantemente aos interesses da vítima em determinadas situações, talvez outros delitos também pudessem ser incluídos no rol dos crimes em que cabe a prévia manifestação da vítima (representação), podendo-se citar exemplificativamente: algumas hipóteses de lesão corporal de natureza grave, como é o caso da prevista no Código Penal, art. 129, §1 ${ }^{\circ}$, I (que resulta incapacidade para as ocupações habituais, por mais de trinta dias) e a violação de domicílio de particular (Código Penal, art. 150), que permanecem ensejando a ação penal de iniciativa pública incondicionada.

De qualquer forma, a inovação pretendida no Código de Processo Penal projetado já representa significativo avanço para os anseios vitimológicos, prestigiando-se sobremaneira a vontade das vítimas de infração penal.

\subsection{CONTROLE SOBRE A ACUSAÇÃO PÚBLICA}

\subsubsection{O controle sobre a acusação pública no atual processo penal brasileiro}

\subsubsection{O controle judicial e o recurso administrativo}

A Constituição Federal de 1988, como é de conhecimento geral, em seu art. 129, inciso I, atribui ao Ministério Público o monopólio sobre a ação penal de iniciativa

\footnotetext{
176 “Art. 46. Será pública, condicionada à representação, a ação penal nos crimes contra o patrimônio previstos no Título II da Parte Especial do Código Penal, quando atingirem exclusivamente bens do particular e desde que praticados sem violência ou grave ameaça à pessoa".
} 
pública, incumbindo, assim, ao Ministério Público o ius accusationis ${ }^{177}$ público, que deve ser exercido em conformidade com a lei.

Dessarte, com base em informações colhidas na investigação preliminar - na maior parte dos casos, em inquérito policial -, o Ministério Público decide por ajuizar ou não a ação penal, a depender da existência de informações suficientes sobre a materialidade e a autoria da infração penal, bem como da inexistência de óbices legais, como causas extintivas de punibilidade. ${ }^{178}$

Na hipótese de o Ministério Público entender pelo não ajuizamento de ação penal, a Lei (inteligência dos arts. 17, 18 e 25, do Código de Processo Penal), exige que o membro daquela instituição requeira ao juiz o arquivamento do inquérito policial (assim como de procedimentos administrativos, peças de informação etc.), cabendo à autoridade judiciária a decisão sobre o arquivamento ou não da investigação preliminar. Importa observar que o juiz não poderá proceder ao arquivamento de ofício, sem o requerimento ministerial, sob pena de incidir indevidamente na persecução penal, violando o sistema acusatório.

Sobre esse ato do juiz, JARDIM enfatiza sua natureza: "não é um mero despacho como pode fazer crer uma leitura apressada do código. Não é sentença por inexistir processo ou jurisdição, mas simplesmente decisão administrativa (sentido lato). Por ser oriundo do Poder Judiciário, torna-se judicial". ${ }^{179}$

Caso o magistrado considere improcedentes as razões invocadas no pedido de arquivamento, conforme o disposto no art. 28, do Código de Processo Penal, fará remessa dos autos do inquérito, do procedimento ou das peças de informação ao Procurador-Geral, que poderá oferecer ele próprio a denúncia, designar outro órgão ministerial para oferecêla, ou insistir no pedido de arquivamento, ao qual só então estaria o juiz obrigado a atender.

Acerca da atuação do chefe do Ministério Público ao insistir no arquivamento,

177 Sobre a distinção entre direito de acusação e acusação: “[...]. Surgem, assim, a ideia de acusação (accusatio) e a de direito de acusação (ius accusationis): a primeira refere-se ao efetivo exercício desse direito, e a última, ao próprio ius accusationis. Se ambas as idéias fossem idênticas, não existiria a experiência do ato acusatório como fato de proceder jurídico que manifesta o próprio uso do direito de acusar". (OLIVEIRA, Gilberto Callado de. O conceito de acusação. São Paulo: Revista dos Tribunais, 1996. p. 104).

${ }_{178}$ LOPES JÚNIOR, na busca de categorias jurídicas próprias (distintas das categorias tradicionais do processo civil), elenca como condições da ação penal: prática de fato aparentemente criminoso (fumus comissi delicti), punibilidade concreta, legitimidade de parte e justa causa. (LOPES JÚNIOR, Aury. Direito processual penal e sua conformidade constitucional. 5. ed. rev. atual. Rio de Janeiro: Lumen Juris, 2010, v.1, p. 356-367).

179 JARDIM, Afrânio Silva. Direito processual penal. 11. ed. Rio de Janeiro: Forense, 2007, p. 166. 
JARDIM observa que, "ao juiz não fica nenhuma faixa de apreciação, nada lhe restando senão determinar ao escrivão que arquive os autos", de modo que "na essência, o Procurador-Geral não requer, mas, sopesando os argumentos do Promotor de Justiça, decide pela cessação das investigações, vale dizer, pelo arquivamento". ${ }^{180}$

Assim, o arquivamento ficaria a depender, primeiramente, do requerimento do Promotor de Justiça, e caso haja concordância do juiz, de sua decisão nesse sentido; em caso de discordância, o arquivamento fica a depender da manifestação final da chefia do Ministério Público, nos moldes do art. 28.

De tais considerações, cumpre ressaltar, com apoio em MAZZILLI, que se trata da única função institucional do Ministério Público em que esse órgão dá a palavra final, sobrepondo-se, inclusive, ao Poder Judiciário. Segundo referido autor, é no não exercício da ação penal que reside a única hipótese em que o Ministério Público condiciona o ius puniendi estatal.

Em termos mais claros, expõe MAZZILLI que "ao contrário do que poderia parecer, o Ministério Público dá a palavra final do Estado soberano não quando acusa, mas apenas quando deixa de acusar". ${ }^{181}$

Essa atuação da autoridade judiciária, ao discordar das razões invocadas pelo promotor de justiça, remetendo os autos ou as peças de informação à instância superior do Ministério Público, constitui a principal forma de controle sobre o ius accusationis público no ordenamento jurídico brasileiro. No desempenho desse mister, o juiz não exerce uma função jurisdicional, mas, na verdade, uma função anômala: a de fiscalizar o princípio da obrigatoriedade da ação penal de iniciativa pública, a ser observado pelo Ministério Público.

Observe-se que esse mecanismo de controle não conta com qualquer participação da vítima, a qual não ganha qualquer menção no desenrolar do procedimento previsto no art. 28, do Código de Processo Penal, restando, mais uma vez, completamente olvidada.

Apercebendo-se de tal omissão em relação às vítimas da infração penal, DEMERCIAN chega a defender que o procurador-geral de justiça possa, a pedido da vítima, rever o arquivamento do inquérito policial ainda que o juiz não tenha discordado das razões invocadas pelo promotor de justiça. Tal entendimento, contudo, mostra-se

${ }^{180}$ JARDIM, Afrânio Silva. Direito processual penal. 11. ed. Rio de Janeiro: Forense, 2007, p. 166. 181 MAZZILLI, Hugo Nigro. Introdução ao ministério público. 7. ed. rev. atual. São Paulo: Saraiva, 2008, p. 124. Conferir os dispositivos legais nesse sentido: CPP, art. 28, Lei n. 8.625/93, art. 29, inciso VII, LC n. $75 / 93$, art. 62. 
minoritário, parecendo não ter aplicação na praxe forense. ${ }^{182}$

Cumpre registrar, a bem da verdade, a existência de outro mecanismo de controle disponibilizado previsto em Lei, este sim, disponibilizado em prol da vítima, mas que tem pouca divulgação. Trata-se do recurso administrativo que pode ser interposto pelo legítimo interessado - conceito em que se pode incluir a vítima - junto ao Colégio de Procuradores de Justiça (art. 12, inciso XI, da Lei n. 8625/93). ${ }^{183}$ Esse recurso, contudo, além de depender de regulamentação na Lei Orgânica de cada Ministério Público, não pode ser manejado em todos os casos, mas somente quando se trata de arquivamento em sede de ação penal de iniciativa pública originária.

\subsubsection{A ação penal de iniciativa privada subsidiária}

Outro mecanismo merece especial referência. É o caso da ação penal de iniciativa privada subsidiária da pública, prevista no art. 29, do Código de Processo Penal, e no art. $100, \S 3^{\circ}$, do Código Penal, que hoje detém status constitucional (art. $5^{\circ}$, LIX, da Constituição Federal). ${ }^{184}$

Embora não se trate propriamente de um mecanismo de controle sobre a decisão de não exercício do ius accusationis público, não deixa de ser um instrumento de controle para a hipótese de inércia quando do exercício de tal direito, representando uma

\footnotetext{
182 "Nada impede, nessa ordem de ideias, que o procurador-geral, expressão máxima da unidade do Ministério Público, a pedido do interessado, reexamine o pedido de arquivamento e, em nome da instituição, dê a última palavra, desde que, como se viu, a decisão de arquivamento não adquira a estabilidade da coisa julgada material (v.g., nas hipóteses de extinção de punibilidade ou atipicidade do fato). Essa solução independe de qualquer alteração legislativa e parece consentânea com os princípios da unidade e da independência funcionais. Em outras palavras, submeter o reexame da matéria, objeto de arquivamento, ao exclusivo controle judicial, limitaria a unidade preconizada pela Constituição Federal (art. $127 \S 1^{\circ}$ ) e, mais do que isso, acabaria por interferir, por via indireta, na própria autonomia institucional (CF, art. 127, $\S 2^{\circ}$ ). Além do mais, como observa, com inteira propriedade, Fernando da Costa Tourinho Filho, se o procurador-geral, mesmo sem novas provas pode rever o arquivamento quando provocado pelo juiz, por que inusitada razão não poderia fazê-lo de ofício?" (DEMERCIAN, Pedro Henrique. Regime jurídico do ministério público no processo penal. São Paulo: Verbatim, 2009, p. 102). Para análise completa das colocações do referido autor, cf. DEMERCIAN, Pedro Henrique. Regime jurídico do ministério público no processo penal. São Paulo: Verbatim, 2009, p. 97-103.

183 "XI - rever, mediante requerimento de legítimo interessado, nos termos da Lei Orgânica, decisão de arquivamento de inquérito policial ou peças de informações determinada pelo Procurador-Geral de Justiça, nos casos de sua atribuição originária".

${ }^{184}$ Cf. histórico desenvolvido desde o Códico Criminal do Império, que previa a acusação supletiva pelo particular, até a Lei n. 8.078/90 (Código de Defesa do Consumidor), que em seu art. 80 passou a admitir o manejo da ação de iniciativa privada subsidiária por entidades ou órgãos da administração pública, bem como instituições particulares. (FERNANDES, Antônio Scarance. O papel da vítima no processo criminal. São Paulo: Malheiros, 1995, p. 111-112).
} 
verdadeira garantia constitucional da tutela penal dos direitos fundamentais da vítima. ${ }^{185}$

A ação subsidiária possibilita ao ofendido, em caso do transcurso in albis do prazo legal para oferecimento de denúncia pelo Ministério Público, o ajuizamento por conta própria de queixa-crime, passando aquele (ofendido) a ostentar legitimidade para deduzir a pretensão acusatória.

Quando se fala de inércia, deve-se frisar que se cuida de inércia do Ministério Público em adotar quaisquer das providências previstas em Lei. Assim, se no curso do prazo legal, o promotor requisitar diligências à autoridade policial ou promover o arquivamento do inquérito policial, a ação subsidiária não se mostra cabível. ${ }^{186}$

Esse mecanismo não se encontra à disposição da vítima indefinidamente, valendo aqui também a regra do prazo decadencial (Código de Processo Penal, art. 38), aplicável à ação penal de iniciativa privada principal. Ou seja, decorrido, in albis, o prazo para oferecimento de denúncia, começa a fluir o prazo decadencial de seis (06) meses para ajuizamento de queixa-crime subsidiária, o qual, uma vez findo, não enseja extinção de punibilidade - afinal, ainda se trata de crime que enseja ação pública -, mas apenas o perecimento do direito, pela vítima, de exercer tal actio.

O tema levanta alguns questionamentos interessantes, por exemplo, qual seria o papel do Ministério Público na ação subsidiária? E qual seria o papel da vítima, uma vez já instaurado o processo penal? Preliminarmente, cumpre deixar claro que, ainda que sob o rótulo de ação penal de iniciativa privada, permanece, no caso, a natureza de ação penal de iniciativa pública. Consequência disso é que ficam preservadas todas as regras específicas desta, como a obrigatoriedade, indisponibilidade, indivisibilidade e intranscendência, não cabendo institutos típicos daquela, como o perdão e a perempção. ${ }^{187}$

Sob tal perspectiva, deve-se enfatizar que na ação de iniciativa privada subsidiária, o Ministério Público não perde seu ius accusationis, assumindo um papel de legitimado concorrente juntamente com a vítima, podendo também aquele veicular a pretensão acusatória. Assim é que devem ser entendidas as atribuições previstas no art. 29,

\footnotetext{
${ }^{185}$ OLIVEIRA, Eugênio Pacelli. Processo e hermenêutica na tutela penal dos direitos fundamentais. 2. ed. rev. atual. Rio de Janeiro: Lumen Juris: 2009, p. 25-28.

186 "Caso tenha pedido diligências ou o arquivamento, mesmo que a vítima não concorde, não há que se falar em inércia e, portanto, inviável a ação penal de iniciativa privada subsidiária”. (destaques do autor). (LOPES JÚNIOR, Aury. Direito processual penal e sua conformidade constitucional. 5. ed. rev. atual. Rio de Janeiro: Lumen Juris, 2010, v.1, p. 398). A respeito, no mesmo sentido: TUCCI, Rogério Lauria. Teoria do direito processual penal: jurisdição, ação e processo penal (estudo sistemático). São Paulo: Revista dos Tribunais, 2002, p. 137-138. 187 Cf. LOPES JÚNIOR, Aury. Direito processual penal e sua conformidade constitucional. 5. ed. rev. atual. Rio de Janeiro: Lumen Juris, 2010, v.1, p. 398-399.
} 
do Código de Processo Penal, o qual dispõe caber ao órgão ministerial aditar a queixa, repudiá-la e oferecer denúncia substitutiva, intervir em todos os termos do processo, fornecer elementos de prova, interpor recurso e, a todo tempo, no caso de negligência do querelante, retomar a ação como parte principal.

Dessarte, uma vez deduzida a pretensão acusatória pela vítima, oferecendo-se a queixa subsidiária, o juiz deve abrir o prazo de três dias para o Ministério Público manifestar-se sobre a acusação (Código de Processo Penal, art. $46 \S 2^{\circ}$ ), prazo em que o órgão ministerial ${ }^{188}$ poderá: a) quedar-se omisso; b) aditar a queixa, incluindo corréus e/ou novos fatos típicos; c) repudiar a queixa e oferecer denúncia substitutiva; d) repudiar a queixa e requerer o não recebimento da queixa subsidiária.

$\mathrm{Na}$ primeira hipótese, a omissão ministerial significa apenas a concordância com a pretensão acusatória trazida pela vítima, nada havendo a retificar ou acrescentar. Em razão de tratar-se, em essência, de ação penal de iniciativa pública, ambos, Ministério Público e vítima permanecem colegitimados a atuar no polo ativo da relação processual. ${ }^{189}$

Na segunda hipótese, o Ministério Público adita a queixa, incluindo corréus e/ou novos fatos típicos. Aqui, o órgão ministerial exerce seu ius accusationis, ampliando a imputação formulada pela vítima. Recebendo o juiz somente a queixa ou esta e o aditamento, permanece a situação de legitimação concorrente.

Na terceira hipótese, poderá o Ministério Público repudiar a queixa subsidiária, oferecendo denúncia substitutiva. Nesse caso, há colidência entre a acusação originária, formulada pela vítima, e a acusação pública que pretende substituir aquela. Caso o juiz acolha ambas parcialmente ou rejeite a acusação pública, permanece a legitimação concorrente, tendo em vista tratar-se, em essência, de ação penal de iniciativa pública. Contudo, caso o juiz receba a denúncia substitutiva e, concordando com o repúdio ministerial à queixa, venha a rejeitar esta peça, não se vislumbra qualquer motivo para subsistir a legitimação concorrente, tendo em vista a exclusão da pretensão acusatória deduzida pela vítima, restando a esta, se assim o desejar, habilitar-se como assistente.

\footnotetext{
${ }^{188}$ Essa concessão de vistas ao Ministério Público, a nosso ver, deve preceder o recebimento da queixa, tendo em vista as possíveis alterações processuais que possam eventualmente surgir após tal intervenção ministerial, que serão melhor solucionadas caso ainda não haja a instauração formal do processo provocada pelo recebimento da peça acusatória da vítima. Propõe-se, assim, simplificando, apenas uma oportunidade para o juízo de admissibilidade da pretensão acusatória, azo em que caberá ao juiz analisar a queixa subsidiária e manifestação ministerial.

189 “Aliás, cumpre observar que a natureza pública da ação instaurada por iniciativa subsidiária do particular há de permitir ao Ministério Público uma ampla participação no processo, como verdadeiro legitimado concorrente". (OLIVEIRA, Eugênio Pacelli. Processo e hermenêutica na tutela penal dos direitos fundamentais. 2. ed. rev. atual. Rio de Janeiro: Lumen Juris, 2009, p. 84).
} 
A quarta hipótese, embora não encontre previsão no art. 29, mostra-se possível. O Ministério Público pode não concordar com a acusação da vítima e entender pela inexistência de fundamento para o ajuizamento de ação penal. Assim, dentro do tríduo legal, postulará o não recebimento da queixa subsidiária. Caso esta seja rejeitada, à vítima, autor da ação subsidiária, assegura-se recurso em sentido estrito (Código de Processo Penal, art. 581, inciso I).

A legitimação concorrente entre Ministério Público e vítima, presente na ação penal de iniciativa privada subsidiária, também deixará de existir se a vítima manifestar negligência nos atos processuais que lhe competirem. Em tal situação, o Ministério Público assumirá a condição de parte principal, isto é, permanecerá no polo ativo, ao passo que a vítima, se ainda quiser retornar à relação processual, deverá postular sua admissão como assistente.

Embora o tema permita ponderações interessantes, ainda pouco exploradas, na prática, de modo geral, a ação penal de iniciativa privada subsidiária raramente é utilizada. O primeiro óbice parece residir no custo decorrente de tal empreitada, que exige o pagamento de honorários advocatícios e de despesas processuais pelo particular, os quais nem sempre podem suportados economicamente pelas vítimas. Por outro lado, a deficiente estrutura da Defensoria Pública dificulta o acesso daquelas à assistência judiciária gratuita do Estado.

Outro óbice também pode ser apontado. É que a vítima não detém poder investigativo, nem dispõe de poder de requisição junto à Polícia Judiciária para cumprir suas diligências, o que dificulta uma atuação mais segura, tanto na seara pré-processual como no âmbito do processo penal.

Aqui cabe uma advertência sobre a ação subsidiária. É que a vítima, em face da inércia do Ministério Público, pode açodadamente ajuizar essa ação, ainda desprovida de fundamentos mais sólidos que poderiam ser colhidos por atividade posterior do órgão ministerial que se quedou inerte. Essa possibilidade, não de todo remota, pode dificultar a persecução penal e mesmo inviabilizá-la em definitivo.

Essas observações parecem apontar a ação penal de iniciativa privada subsidiária como um instrumento interessante, contudo, de difícil viabilização na prática, e que pode ensejar revezes significativos para a persecução penal.

Dessas perspectivas, acrescidas às considerações tecidas no item 4.3.1.1, facilmente se pode concluir que o ordenamento jurídico brasileiro precisa de novos instrumentos de controle sobre o ius accusationis público, que contem com a participação 
da vítima, e que sejam dotados de efetividade e de viabilidade prática, não devendo ainda representar riscos para a persecução penal.

\subsubsection{Novas perspectivas}

\subsubsection{Perspectivas de direito comparado}

Antes de se passar à análise de alguns institutos pertencentes ao Direito alienígena, concernentes ao controle sobre a acusação pública, cabe advertir que tal estudo, para ser mais completo, em homenagem a um maior rigor científico, careceria de uma prévia e ampla análise geral sobre os ordenamentos jurídicos em que se encontram inseridos, evitando-se sua descontextualização.

Contudo, uma análise de tal monta, poderia desviar o foco do presente estudo, prejudicando suas finalidades. Assim, propõe-se aqui ${ }^{190}$ a análise sobre alguns institutos do direito comparado, precedida de uma brevíssima introdução sobre o processo penal do respectivo país e seu enlace com a vítima, em uma tentativa de minimizar o risco apontado no parágrafo anterior.

Por fim, cabe o esclarecimento quanto aos critérios utilizados visando à seleção dos ordenamentos jurídicos aqui visitados.

Primeiramente, buscou-se o estudo de ordenamentos jurídicos europeus tradicionalmente tidos como fonte de referência e de inspiração legislativa para as demais legislações e que proviessem da mesma cepa jurídica do ordenamento brasileiro (tradição romano-germânica ou continental), a fim de facilitar a aproximação com nosso ordenamento. É o caso da Alemanha e da Itália. O ordenamento jurídico português, por sua vez, além de sua proeminência quanto ao tratamento da vítima, ainda conta com inescondível vínculo histórico com o direito brasileiro. Buscou-se também a análise de um ordenamento latino-americano, optando-se pelo ordenamento da Argentina, que além de sua expressividade regional, confere rico tratamento às vítimas da infração penal.

\footnotetext{
${ }^{190}$ Essa análise servirá para os itens posteriores que tratam do direito comparado neste trabalho.
} 


\subsection{Alemanha}

O ordenamento jurídico alemão tem por base sua Lei Fundamental, de 1949 (a Grundgesetz für die Bundesrepublik Deutschland, ou simplesmente Grudgesezt $(G G)$ ). O Direito Processual Penal alemão é regulamentado pela Lei de Processo Penal, a Strafprozessordnung (StPO), pela Lei de Organização Judiciária, Gerichtsverfassungsgesetz $(G V G)$, ambas datadas de 1877, e por legislação posterior.

O processo penal alemão - que adota o sistema acusatório contemporâneo ${ }^{191}$ em seu rito ordinário, divide-se em três fases: o procedimento preliminar, o procedimento intermédio e o procedimento principal.

O procedimento preliminar, de caráter sigiloso e escrito, ${ }^{192}$ destina-se, segundo a literatura jurídica, a "alcançar uma decisão do ministério público a respeito do exercício da ação penal". ${ }^{193}$

Nesse procedimento, ao Ministério Público ${ }^{194}$ incumbe dirigir e controlar as investigações, podendo decretar medidas sem intervenção judicial, como a prisão em

\footnotetext{
${ }^{191}$ O sistema processual penal misto, adotado na Alemanha, recebeu um duro golpe em 1974, em prol da construção do sistema acusatório contemporâneo. É que a grande reforma da StPO, naquele mesmo ano, extinguiu o juizado de instrução e conferiu ao Ministério Público alemão a responsabilidade pelo procedimento de investigação preliminar, "dando início a uma forte discussão em toda a Europa sobre o futuro ou manutenção do processo penal difundido pelo Code d'Instruction Criminelle, de 1808, que tinha o juiz de instrução como seu protagonista". (ANDRADE, Mauro Fonseca. Sistemas processuais penais e seus princípios reitores. Curitiba: Juruá, 2010, p. 106).

192 "Com a suficiência da notitia criminis se inicia o procedimento preliminar escrito, secreto e conduzido pelo Ministério Público, em que, como regra o acusado e seu defensor não têm direito à assistência nas investigações, salvo em situações excepcionais." (ANDRADE, Mauro Fonseca. Sistemas processuais penais e seus princípios reitores. Curitiba: Juruá, 2010, p. 121).

${ }_{193}$ FERNANDES, Fernando. O processo penal como instrumento de política criminal. Coimbra: Almedina, 2008. (Coleção teses), p. 119.

${ }^{194}$ O Ministério Público alemão apresenta estrutura acentuadamente hierarquizada. Segundo GIACOMOLLI, “Tanto o Ministério Público Federal quanto o Estadual, possuem dependência hierárquica interna (funcional) [...]. Esta dependência se verifica principalmente no direito dos superiores em emitir ordens de serviço e no dever dos subordinados de acatá-las. Considerando-se que o Procurador-Geral Federal é nomeado pelo Presidente da Federação, mediante proposta do Ministro da Justiça, pode ser afirmada a existência de uma inevitável dependência externa, pelo menos em termos de política criminal, pois é o superior quem delimita as linhas gerais a serem seguidas". (GIACOMOLLI, Nereu José. Legalidade, oportunidade e consenso no processo penal na perspectiva das garantias constitucionais: Alemanha, Espanha, Itália, Portugal e Brasil. Porto Alegre: Livraria do Advogado, 2006, p. 120). O poder hierárquico dos superiores encontra, porém, limites. Segundo DEMERCIAN, não se pode determinar ao promotor o exercício da ação penal quando não estiverem presentes os indícios suficientes, bem como seu não exercício, em caso de presença de tais indícios, assim como em outras situações. $\mathrm{O}$ autor destaca ainda que as ordens quanto à atividade-fim devem obedecer à legalidade e que o membro da instituição tem o direito de contestar a ordem, sendo-lhe assegurada sua inamovibilidade. (DEMERCIAN, Pedro Henrique. Regime jurídico do ministério público no processo penal. São Paulo: Verbatim, 2009, p. 40-42).
} 
flagrante ( $\$ 127$, II, da $S t P O)$ e o sequestro de bens móveis ( $\$ 98$, da $S t P O$ ), e outras sujeitas ao controle judicial, como a prisão processual, a busca e apreensão domiciliar, o reconhecimento, o sequestro de obra escrita (§111, “n” e 114, I, da StPO). 195

É de bom alvitre esclarecer que o processo penal alemão segue o princípio da obrigatoriedade (legalidade) quanto à propositura da ação penal, ressalva feita à ação penal privada (Privatklage), em que vige o princípio da oportunidade. Todavia, mesmo não se tratando de ação penal privada, o princípio da obrigatoriedade sofre diversas limitações ou atenuações, ${ }^{196}$ que podem ser resumidas sob quatro grandes grupos, citados por ROXIN: a) quando o ato é insignificante e não existe um interesse público na persecução; b) quando o interesse público pode ser satisfeito de outra forma; c) quando existem interesses estatais contrários à persecução; d) quando o próprio ofendido pode proceder à persecução. ${ }^{197}$

Uma vez exercida a ação penal pelo Ministério Público, abre-se o procedimento intermediário, que não passa de um verdadeiro juízo de admissibilidade sobre a acusação. ${ }^{198}$

Admitida a acusação, ${ }^{199}$ instaura-se o procedimento principal, em que se dá a leitura da acusação, o interrogatório do acusado, a apresentação de provas, as alegações das partes e a sentença, tudo sob os influxos do princípio do contraditório e do princípio da oralidade e seus consectários (imediação e concentração, aceleração do processo e continuidade da audiência de julgamento e identidade física do juiz). ${ }^{200}$

Conforme anota KINDHÄUSER, a StPO, desde sua sanção, no longínquo ano

195 Cf. GIACOMOLLI, Nereu José. Legalidade, oportunidade e consenso no processo penal na perspectiva das garantias constitucionais: Alemanha, Espanha, Itália, Portugal e Brasil. Porto Alegre: Livraria do Advogado, 2006, p. 120.

196 "De facto, sustenta ROXIN que o princípio da legalidade está sujeito a tantas limitações na actualidade que no campo da criminalidade leve e também da criminalidade média vale praticamente o princípio da oportunidade". (FERNANDES, Fernando. O processo penal como instrumento de política criminal. Coimbra: Almedina, 2008. (Coleção teses), p. 319).

${ }^{197}$ Cf. FERNANDES, Fernando. O processo penal como instrumento de política criminal. Coimbra: Almedina, 2008. (Coleção teses), p. 311. Para uma análise mais profunda acerca das limitações do princípio da obrigatoriedade, cf. ainda: Ibid., p. 309-414, e TIEDEMANN, em: ROXIN, Claus; ARZT, Gunther; TIEDEMANN, Klaus; Introdução ao direito penal e ao direito processual penal. Tradução de Gercélia Batista de Oliveira Mendes. Belo Horizonte: Del Rey, 2007, p. 195-202.

198 Ressalvando o controle exercido pelo próprio Ministério Público sobre a existência ou não de fundamentos para ação penal, FERNANDES anota que “[...] o filtro processual do exercício da acção penal no Ordenamento Jurídico germânico pode ser considerado o procedimento intermédio. Previsto nos $\S \S 199$ e seguintes da $S t P O$, através dele verifica-se a existência de 'suspeitas suficientes' contra o arguido em relação ao facto perseguido ( $\$ 203 S t P O)$." ( FERNANDES, Fernando. O processo penal como instrumento de política criminal. Coimbra: Almedina, 2008. (Coleção teses), p. 119).

199 "Inconsistente a acusação, o caminho é o arquivamento (§ 204 da StPO), cabendo recurso ( $\$ 210$, II, da StPO)". (GIACOMOLLI, Nereu José. Legalidade, oportunidade e consenso no processo penal na perspectiva das garantias constitucionais: Alemanha, Espanha, Itália, Portugal e Brasil. Porto Alegre: Livraria do Advogado, 2006, p. 124).

${ }^{200}$ DEMERCIAN, Pedro Henrique. Regime jurídico do ministério público no processo penal. São Paulo: Verbatim, 2009, p. 36-37. 
de 1877 , não era de todo alheia à vítima, a qual, entretanto, "aparecia unicamente en algumas reglamentaciones puntuales y no estaba previsto para uma función procesal especifica”. ${ }^{201}$ Contudo, o processo alemão progressivamente passou a preocupar-se com as vítimas de delito, o que pode ser verificado à vista da Lei de Reparação de Crimes Violentos, de 1976, que segundo CÂMARA, haveria de influenciar os demais países europeus para estabelecerem algum mecanismo de compensação para as vítimas, "tendo-se optado por um modelo de indenização estatal subsidiária, ainda que limitado a hipóteses bem espartilhadas". ${ }^{202}$ (destaques do autor).

A viragem em prol da vítima deu-se de forma decisiva a partir do $55^{\circ}$ Congresso alemão de juristas (55 Deutsche Juristentag), em 1984, em que se tratou especificamente acerca da posição jurídica da vítima no processo penal. Esse congresso motivou a edição da Lei de Proteção das Vítimas, de $1986,{ }^{203}$ a qual trouxe os seguintes direitos para as vítimas de delito, citados por CÂMARA, a título exemplificativo: a) direito de vista dos autos por advogado, já no procedimento preliminar (\$ 406, e, StPO); b) direito a auxílio do advogado durante seu depoimento ( $\$ 406, f, S t P O)$; c) direito de, ao ser ouvido como testemunha, contar com uma pessoa de confiança, salvo se a presença desta colocar em risco os fins da investigação $\left.(\$ 406, f, 3, S t P O)^{204} \mathrm{~d}\right)$ direito à informação acercados próprios direitos e do direito de funcionar ao lado do Ministério Público na ação pública por este ajuizada ( $\$ 406, h, S t P O)$; e) direito de, ao ser ouvido como testemunha, requerer a retirada do acusado durante o depoimento ( $(247, S t P O)$; f) direito a uma proteção mais

${ }^{201}$ Cf. KINDHÄUSER, Urs. (et. al.). Criminalidad, evolución del derecho penal y crítica al derecho penal en la actualidad. Buenos Aires: Del Puerto, 2009, p. 144. Apenas para fins de registro, o referido autor (KINDHÄUSER), por não vislumbrar qualquer ligação da vítima à finalidade da pena de restituir simbolicamente a perda de vigência da norma violada por ocasião da prática do delito, defende a inserção daquela no processo penal com reservas, considerando seus interesses como secundários caso confrontados com os interesses do acusado e com a necessidade de se encontrar a verdade pelo processo penal. Quanto à previsão de normas relativas à vítima na redação original do StPO, D’ALBORA aponta que desde 1877 existia uma acción adesiva, a saber, a possibilidade de colaborar com o Ministério Público (equivalente à nossa assistência). (D’ALBORA, Francisco J. El querelante y la víctima. Ciencias Penales Contemporáneas: Revista de Derecho Penal, Procesal Penal y Criminología, Mendoza, v. 1, n. 2, p.115135, 2001, p. 123).

${ }^{202}$ CÂMARA, Guilherme Costa. Programa de política criminal orientado para a vítima do crime. São Paulo: Editora Revista dos Tribunais; Coimbra: Coimbra Editora, 2008, p. 309.

${ }^{203}$ Para uma análise mais detida sobre essa viragem em prol da vítima, que inclusive contou com leis posteriores à de 1986, como a Lei de Proteção das Testemunhas e para a Melhora da Proteção da Vítima, de 1998, e a Lei para Melhora dos Direitos dos Ofendidos no Processo Penal, de 2004, cf. SCHÜNEMANN, Bernd. Obras. Buenos Aires: Rubinzal-Culzoni, 2009, v. 2. (Colección autores de derecho penal), p. 485489.

204 Neste ponto, CÂMARA recorda que a vítima-testemunha tem o direito de recusar-se a depor (Zeugnisverweisungsrecht), com base na proteção da vida privada, em razão de interpretação dada aos artigos 1 e 2 da GG, pelo Tribunal Constitucional alemão, devendo ser levados em consideração, no caso concreto, alguns critérios como a gravidade da infração e a existência de outros elementos probatórios. (CÂMARA, Guilherme Costa. Programa de política criminal orientado para a vítima do crime. São Paulo: Editora Revista dos Tribunais; Coimbra: Coimbra Editora, 2008, p. 311). 
efetiva quanto aos efeitos da publicidade processual $(\S 171, b, G V G) .^{205}$

Tecidas essas considerações gerais sobre o processo penal alemão e seu enlace com a vítima, convém adentrar no estudo específico acerca do controle sobre a acusação pública. $\mathrm{O}$ mecanismo conferido à vítima para controle sobre o Ministério Público, referido por SCHÜNEMANN, consiste em um procedimento utilizado para impugnar o arquivamento do procedimento preliminar, determinado pelo Ministério Público alemão. ${ }^{206}$

Uma vez arquivado o procedimento por tal instituição, o requerente do pedido de instauração da instância penal e a vítima da infração penal deverão ser notificados ( $\S \S$ 170 e 171, StPO), ocasião em que serão cientificados do procedimento para compelir a promoção da ação penal pública, em duas semanas, sendo tal impugnação dirigida ao superior hierárquico (o chefe do Ministério Público perante a Corte de Apelo, o chefe da instituição perante a Suprema Corte, ou mesmo, em último grau, o próprio Ministro da Justiça). ${ }^{207}$

Caso a impugnação perante a autoridade hierárquica superior seja denegada, a vítima poderá interpor uma impugnação junto ao Tribunal Superior do Estado (Oberlandsgericht), juízo em que se poderá realizar diligências, tais como ouvir o suspeito e a vítima. Caso seja dado provimento ao pedido, o Tribunal determinará ao Ministério Público o ajuizamento da ação penal. ${ }^{208}$ Se confirmado o arquivamento, a decisão não se reveste da autoridade da coisa julgada, podendo ser revista em caso de surgimento de outras provas. $^{209}$

${ }^{205}$ CÂMARA, Guilherme Costa. Programa de política criminal orientado para a vítima do crime. São Paulo: Editora Revista dos Tribunais; Coimbra: Coimbra Editora, 2008, p. 310-311.

${ }^{206}$ SCHÜNEMANN aponta, em tom crítico, a importância de tal controle: "[...] No pueden caber dudas acerca de la importancia de un control de este tipo, pues tanto en los casos de procesados politicamente influyentes como también en aquellos otros en los que la persecución penal resulta costosa y laboriosa para el Ministerio Fiscal, existe para el Ministerio Fiscal la enorme tentación de ahorrarse los consiguientes esfuerzos sobreseyendo el proceso o en el futuro que él mismo se recomiende para un ascenso si el procesado dispone de buenas relaciones con el Ministerio de Justicia. Precisamente porque el ministro de Justicia decide sobre los ascensos en el ámbito dela fiscalia, posse una gran influencia extraoficial sobre el Ministerio Fiscal independientemente de la cuestión del derecho de su superior, y por medio de ésta se constituye el peligro, de que la decisión sobre el sobreseimiento este políticamente influenciada.[...]". (SCHÜNEMANN, Bernd. Obras. Buenos Aires: Rubinzal-Culzoni, 2009, v. 2. (Colección autores de derecho penal), p. 501). Segundo o referido autor, tal mecanismo já constava originalmente no StPO, em 1877. (SCHÜNEMANN, Bernd. Obras. Buenos Aires: Rubinzal-Culzoni, 2009. v. 2. (Colección autores de derecho penal), p. 500).

${ }^{207}$ DEMERCIAN, Pedro Henrique. Regime jurídico do ministério público no processo penal. São Paulo: Verbatim, 2009, p. 39.

${ }^{208}$ Perceba-se que não cabe ao Tribunal instaurar o procedimento ex officio, porém aquele determina tal instauração ao titular do monopólio de acusação penal, no que exsurge, a princípio, um sério questionamento quanto a possível violação do princípio acusatório.

${ }^{209}$ DEMERCIAN, Pedro Henrique. Regime jurídico do ministério público no processo penal. São Paulo: Verbatim, 2009, p. 39. Conferir ainda: ESER, Albin. Acerca del renacimiento de la víctima en el procedimiento penal: tendencias nacionales e internacionales. Tradução de Fabrício O. Guariglia e Fernando 
A literatura jurídica alemã ainda destaca que nos casos em que vige o princípio da oportunidade $(\S 153, S t P O)$, o procedimento de controle em análise não se mostra cabível, de modo que à vítima não se confere qualquer controle efetivo sobre o arquivamento em tais hipóteses. $^{210}$

\subsection{Itália}

O Codice di Procedura Penale (c.p.p.), de 1988, ${ }^{211}$ vigente desde 24.10.1989, representou uma afirmação do sistema processual penal acusatório contemporâneo perante o sistema predominantemente inquisitório, que dava vida ao Código de 1930, também conhecido por Codice Rocco. ${ }^{212}$ A mudança mostrou-se tão radical que, após a vigência do c.p.p., ocorreram sucessivas alterações em detrimento do sistema acusatório. ${ }^{213}$

Precede o rito ordinário do processo penal italiano o procedimento denominado de indagini preliminari (investigações preliminares). ${ }^{214} \mathrm{Em}$ se atribuindo ao pubblico

J. Córdoba. In: MAIER, Julio B. J. (Comp.). De los delitos y de las víctimas. Buenos Aires: Ad Hoc, 2001. p. 13-52, p. 27.

${ }^{210}$ Cf. nota 22 em: DEMERCIAN, Pedro Henrique. Regime jurídico do ministério público no processo penal. São Paulo: Verbatim, 2009, p. 39 e SCHÜNEMANN, Bernd. Obras. Buenos Aires: RubinzalCulzoni, 2009. v. 2. (Colección autores de derecho penal), p. 501-502, lembrando este o respaldo jurisprudencial.

${ }^{211}$ Código de Processo Penal italiano (C.P.P.): ITÁLIA. Codice di procedura penale. Disponível em: $<$ http://www.altalex.com/index.php?idnot=2011>. Acesso em: 09 jun. 2011.

${ }^{212}$ Cf. análise sobre o Código de 1988 e o sistema acusatório: FERRAJOLI, Luigi. Direito e razão: teoria do garantismo penal. Tradução de Ana Paulo Zomer, Fauzi Hassan Choukr, Juarez Tavares e Luiz Flávio Gomes. São Paulo: Revista dos Tribunais, 2002, p. 590-592.

${ }^{213}$ Para TONINI, "A situação ocorrida, após a entrada em vigor do Código de 1988, poderia ser comparada àquela que se verificou em 1791, na qual o legislador revolucionário quis introduzir no ordenamento francês o processo penal inglês da época, sem que o fizesse de forma gradual. O sistema acusatório chocou-se com a mentalidade dos operadores do direito, habituados a outros modelos culturais, e as alterações legislativas do processo penal, que ocorreram sucessivamente durante vinte anos, culminaram no advento da codificação napoleônica de 1811. [...] As considerações até então estabelecidas evidenciam as razões pelas quais o Código de 1988 foi submetido a sucessivas alterações após a sua entrada em vigor [...]." (TONINI, Paolo. A prova no processo penal italiano. Tradução de Alexandra Martins e Daniela Mróz. São Paulo: Revista dos Tribunais, 2002, p. 18-19).

${ }^{214}$ Em relação ao direito processual penal italiano, refere FERNANDES “[...] uma separação entre procedimento e processo a partir do divisor representado pelo ingresso do juiz para verificar uma determinada imputação proposta pelo ministério público, ou seja, o exercício da acção penal, distinguindo-se plenamente as atividades tipicamente processuais daquelas referidas ao procedimento amplamente considerado [...]". (FERNANDES, Fernando. O processo penal como instrumento de política criminal. Coimbra: Almedina, 2008. (Coleção teses), p. 168). A distinção fica clara nas lições de GAROFOLI: "Le indagini preliminari sono la prima fase del procedimento penale. La funzione essenziale è quella di permettere al magistrato del pubblico ministero di racogliere tutti gli elementi che potranno essere utili ai fini dela valutazione circa l'opportunità di esercitare l'azione penale passando, così, alla fase processuale, 
ministero $^{215}$ o monopólio da ação penal, em decorrência do princípio da obrigatoriedade, previsto no art. 112 , da Constituição italiana, ${ }^{216}$ cabe-lhe presidir esse procedimento de investigações preliminares, que se destina a reunir as informações necessárias para a formação de um juízo sobre o exercício ou não da ação penal, com o que conta com a subordinação da polícia judiciária. ${ }^{217}$

Com base nas investigações realizadas, trazidas nos fascicoli delle indagini (autos do procedimento investigatório), o Ministério Público (pubblico ministero) poderá, fundado em justa causa, requerer a prorrogação do prazo para conclusão do procedimento ao juiz (richiesta di proroga del termine), ${ }^{218}$ proceder ao pedido de arquivamento (richiesta di archiviazione) ${ }^{219}$ ou exercer a ação penal (richiesta di rinvio a giudizio). ${ }^{220}$

Apresentada a richiesta di rinvio a giudizio, na secretaria do juízo, será aprazada, dentro de trinta (30) dias, a udienza preliminare (artigos 416 a 433, do c.p.p. ${ }^{221}$ ). $\mathrm{Na}$ referida audiência, o pubblico ministero expõe, de forma sintética, o resultado das investigações e as informações constantes nos autos, facultando-se ao acusado submeter-se a interrogatório, e abrindo-se a oportunidade para argumentação pelas partes. Não havendo

vale a dire l'udienza preliminare ed eventualmente il dibattimento". (GAROFOLI, Vincenzo. Diritto processuale penale. Milão: Giuffrè, 2008, p. 259).

${ }^{215}$ Convém recordar que os membros do Ministério Público italiano integram a magistratura, sendo também conhecidos como magistrados-requerentes e gozando das mesmas prerrogativas dos magistrados-judicantes. Cf DEMERCIAN, Pedro Henrique. Regime jurídico do ministério público no processo penal. São Paulo: Verbatim, 2009, p. 151.

216 "No âmbito penal o Ministério Público possui a titularidade exclusiva da ação penal, que está incumbido de exercer segundo o princípio da obrigatoriedade (na acepção do artigo $112^{\circ}$ da Constituição). Tais funções comportam substancialmente dois tipos de atividades de natureza diversa mas funcionalmente ligadas entre si: uma atividade de tipo investigativo e outra de tipo forense [...]". (FABRI, Marco; CAVALLINI, Daniela. O Ministério Público em Itália. Tradução de Eurico Ventura Pereira. In: DIAS, João Paulo; AZEVEDO, Rodrigo Ghiringhelli de. (Coord.). O papel do ministério público: estudo comparado dos países latinoamericanos. Coimbra: Almedina, 2008. p. 167-221, p. 196). Sobre o perfil constitucional do monopólio sobre a acusação: "Il monopolio, anche se non elevato a principio costituzionale - tale è l'interpratazione che la Corte costituzionale dà dell'art.112 Cost.: v. le sentenze n. 474 del 1993 ('in Giur.cost.', 1993, p. 3899 ss.) è stato suffragato con la nuova codificazione: l'art. 231 norme coord. c.p.p. ha abrogato le disposizioni extracodicistiche, che consentivano l'esercizio dell'azione penale da parte di organi diversi dal pubblico ministero [...]". (AIMONETTO, Maria Gabriella. Azione penale e ruolo della vittima in Italia e Francia. L'indice Penale, Padova, v. 29, n. 1, p.185-211, genn./apr. 1995, p. 188).

217 "A dirigere le indagini è il magistrato del pubblico ministero il quale dispone diretamente della polizia guidiziaria che, anche dopo la comunicazione dela notizia di reato, continua a svolgere attività di propria iniziativa." (GAROFOLI, Vincenzo. Diritto processuale penale. Milão: Giuffrè, 2008, p. 259).

${ }^{218}$ Arts. 406 e 407, do c.p.p.

${ }^{219}$ Arts. 408, do c.p.p.

${ }^{220}$ Arts. 416 e 417 , do c.p.p.

221 “L'udienza preliminare è una fase processuale volta ad assicurare, con il filtro delibativo, la non instaurazione di giudizi superflui. Questa fase, infatti, è adibita a selezionare $i$ procedimenti penali meritevoli di giungere alla fase del dibattimento, con notevole vantaggio per l'economia processuale, nonché alla scelta di riti alternativi al guidizio ordinario, come il patteggiamento e il rito abbreviato che consentono di realizzare un risparmio di energie processual per l'ordinamento e una sensible riduzione di pena per l'imputato". (GAROFOLI, Vincenzo. Diritto processuale penale. Milão: Giuffrè, 2008, p. 315). 
necessidade de ulteriores investigações complementares, ${ }^{222}$ ao juiz apresentam-se duas opções: a sentenza di non luogo a procedere (art. 425, do c.p.p.), que extingue o procedimento, ${ }^{223}$ ou o decreto che dispone al giudizio (art. 429, do c.p.p.), formando-se, nesse último caso, o fascicolo per il dibattimento, a autuação que será remetida à fase seguinte. $^{224}$

A principal fase do rito ordinário consiste no giudizio, que compreende os atos preliminares, dibattimento e sentença, (artigos 465 a 548, do c.p.p.). Nessa fase é que vigem em plenitude os princípios do contraditório, da concentração, da oralidade e da imediatidade $^{225}$ propiciando-se a produção de provas pelas partes e pelo juiz, ${ }^{226}$ e decidindo-se, ao final, a causa.

$\mathrm{Na}$ legislação processual penal italiana, a concepção de persona offesa dal reato (pessoa ofendida pela prática do crime) denota um caráter exclusivamente penalístico, tendo sua definição ligada à titularidade do bem jurídico-penal protegido pela norma violada, ${ }^{227}$ distinguindo-se do conceito de parte civile, cuja atuação é vinculada à

222 Em havendo necessidade de investigações complementares, o juiz poderá fixar o prazo para sua conclusão, marcando nova data para audiência ou, caso vislumbre a possibilidade de absolvição (tão-somente nessa hipótese), poderá determinar a produção de provas de ofício na própria audiência ou em data a ser aprazada (attività di integrazione probatoria del giudice): artigos 421-bis e 422, do C.P.P.

${ }^{223}$ GAROFOLI enumera as hipóteses para tal provimento, que se equipara a uma absolvição sumária: " $L a$ sentenza di non luogo a procedere è un provvedimento che estingue il procedimento penale in quanto gli elementi raccolti non sono in grado di sostenere l'accusa in giudizio; essa viene pronunciata quando sussiste una causa che estingue il reato o per la quale l'azione penale non doveva essere iniziata o proseguita, se il fato non è previsto dalla legge come reato ovvero quando resulta che il fato non sussiste o che l'imputato non lo ha comesso o che il fato non costituisce reato o che si trata di persona non punibile per qualsiasi causa. Un'importante novità 'ex' legge $n .479$ del 1999 riguarda la possibilità per il giudice di pronunciare sentenza di non luogo a procedere anche quando gli elementi acquisiti risultano insufficienti, contraddittori o comunque non idonei a sostenere l'accusa in giudizio alla stessa stregua di quanto accade al termine del dibattimento (art. 530, comma 2, c.p.p.). (GAROFOLI, Vincenzo. Diritto processuale penale. Milão: Giuffrè, 2008, p. 338).

${ }^{224}$ No processo penal italiano, em regra, somente os elementos de prova produzidos sob o princípio do contraditório, em juízo, assegurados os direitos e garantias do acusado, poderão ser considerados pelo juiz por ocasião do julgamento da causa. Assim, ao giudizio não são remetidos os fascicoli delle indagine, ressalvadas algumas exceções como os elementos de prova produzidos em incidente probatório, os elementos de prova de caráter irrepetível e aqueles em que haja consenso das partes para tal remessa. As demais informações, incluídas investigações defensivas e atos da udienza preliminare, devem ser obstaculizadas de apreciação judicial, permanecendo em autuação à parte (fascicolo del pubblico ministero), na secretaria do Ministério Público, disponível para consulta pelas partes. Nesse sentido, GAROFOLI, Vincenzo. Diritto processuale penale. Milão: Giuffrè, 2008, p. 340 e 341, e DEMERCIAN, Pedro Henrique. Regime jurídico do ministério público no processo penal. São Paulo: Verbatim, 2009, p. 50.

${ }^{225}$ DEMERCIAN, Pedro Henrique. Regime jurídico do ministério público no processo penal. São Paulo: Verbatim, 2009, p. 50 e GAROFOLI, Vincenzo. Diritto processuale penale. Milão: Giuffrè, 2008, p. 393.

226 Consoante TONINI, a iniciativa probatória do juiz penal é de caráter excepcional, pois é de regra geral o princípio dispositivo. Ressalta que essa atividade judicial varia conforme a fase do procedimento, sendo que no dibattimento, os poderes de iniciativa probatória judicial são mais amplos. Conferir essa análise na íntegra em: TONINI, Paolo. A prova no processo penal italiano. Tradução de Alexandra Martins e Daniela Mróz. São Paulo: Revista dos Tribunais, 2002, p. 91-97.

227 "La dottrina italiana è concorde nel ritenere che ogni sforzo definitorio volto a determinare il concetto di persona offesa dal reato debba fare riferimento all'oggetto giuridico del reato stesso, vale a dire all'oggetto 
defesa dos interesses civis.

Os diversos direitos da persona offesa dal reato, previstos em Lei, concentramse mais na fase das investigações preliminares, tendo em vista que o c.p.p., após o ajuizamento da ação penal, privilegia o tratamento da parte civile, ou seja, do sujeito que restou civilmente prejudicado pela prática do delito.

Tomem-se os principais direitos assegurados à persona offesa dal reato durante as indagini preliminari, concernentes ao controle sobre a acusação pública, a saber, a provocação da avocação das investigações pelo procurador-geral, a apresentação de razões em caso de pedido de prorrogação de investigações e o controle sobre o arquivamento das indagini preliminari.

A provocação da avocação encontra-se prevista no art. 413, do c.p.p., que assegura à vítima requerer a avocação ao procurador-geral quando o pubblico ministero não exercita a ação penal nem requer o arquivamento por ocasião do término do prazo legalmente estabelecido ou fixado pelo juiz em caso de prorrogação. Mesmo em se tratando de dever do procurador-geral (art. 412, 1), abre-se à vítima a possibilidade de provocar tal avocação. Uma vez efetuada essa, incumbe ao procurador-geral realizar as investigações e formular seus pedidos dentro de trinta (30) dias a contar do pedido formulado pela vítima (art. 412, 2).

No caso de se formular pedido de prorrogação das investigações, o giudice per le indagini preliminari deve notificar acerca do referido pedido tanto o suspeito quanto a vítima que tenha declarado interesse em tal notificação, facultando-lhes a apresentação de razões dentro de cinco (05) dias (art. 406, 3, do c.p.p.). Caso não seja deferida a prorrogação, o indeferimento deve ser comunicado também à vítima (art. 406, 5, do c.p.p.).

Por fim e não menos importante, o controle que a vítima pode exercer quanto ao arquivamento das investigações. Conforme o art. 408, 2 e 3, e 410, do c.p.p., o pubblico ministero, ao requerer o arquivamento, deve notificar a vítima que anteriormente tenha declarado interesse em tal notificação. Nesse ato, deve-se facultar à vítima, no prazo de dez (10) dias, a apresentação de oposição ao arquivamento e de pedido motivado pela persecução penal.

Com o oferecimento de oposição pela vítima, o juiz não poderá mais decidir de

della tutela giuridico-penale. [...] La nozione di offeso è dunque di stretto ambito penalistico." (AIMONETTO, Maria Gabriella. Azione penale e ruolo della vittima in Italia e Francia. L'indice Penale, Padova, v. 29, n. 1, p.185-211, genn./apr. 1995, p. 189). O art. 90, 2 e 3, do C.P.P. indica a possibilidade de representação da vítima nos casos de menoridade, enfermidade mental etc. e a transmissão dos direitos e faculdades aos parentes próximos em caso de morte daquela. 
plano, a não ser que a oposição não seja admitida. Se admitida a oposição, o juiz deve fixar uma audiência em camera di consiglio, procedimento especial previsto no art. 127, do c.p.p., ocasião em que se prolatará a decisão. ${ }^{228}$

\subsection{Portugal}

Abandonando o sistema inquisitorial adotado pelo Código de Processo Penal de $1929^{229}$, o Código de Processo Penal português, de 1987 (CPPP ${ }^{230}$ ), adaptando-se aos moldes da Constituição Portuguesa de $1976,{ }^{231}$ instituiu um sistema acusatório, porém atenuado pelo princípio da investigação oficial.

Nesse contexto, as investigações preliminares passaram a ficar sob a responsabilidade do Ministério Público, ${ }^{232}$ ao qual compete dirigir o inquérito, assistido pelos órgãos de polícia criminal atuando estes sob sua direta orientação e sob sua

${ }^{228}$ GAROFOLI, Vincenzo. Diritto processuale penale. Milão: Giuffrè, 2008, p. 312-313.

${ }^{229}$ O Código de 1929 atribuía ao juiz, além da função de julgamento, a função de investigação preliminar. Uma vez concluídas as investigações, o exercício ou não da ação penal cabia ao Ministério Público, mantendo-se, assim, ao menos sob o aspecto formal, uma orientação acusatória.

${ }^{230}$ PORTUGAL. Código de processo penal. Disponível em: <http://www.portolegal.com/CPPen.htm>. Acesso em: 09 jun. 2011.

231 "A Constituição da República Português de 1976 consagrou, no seu artigo $32^{\circ} \mathrm{n}^{\circ}$ 5, a estrutura acusatória do processo penal, cabendo o exercício da acção penal ao Ministério Público - artigo $224-^{\circ} n^{\circ} 1$, na redaç̧ão originária (actual artigo $219^{\circ} \mathrm{n}^{\circ}$ 1). A interpretação da norma do $\mathrm{n}^{\circ} 4$ do artigo $32^{\circ}$ da Constituição, que dispunha que 'toda a instrução será da competência de um juiz', gerou acesa controvérsia e criou sérias dificuldades, tendo pecado por excesso ao cometer ao juiz de instrução todos os actos de execução de instrução, concepção que dava 'o flanco à critica velha (1937), mas verdadeira, de que a função do juiz é dar decisões e de modo nenhum fazer o trabalho de polícia e dos órgãos encarregados de investigação'. Após a entrada em vigor da Constituição, foi publicada uma série de diplomas legais visando adequar o direito ordinário ao direito constitucional e ultrapassar as dificuldades surgidas. Para além da proliferação legislativa, que se registou, há a assinalar a grande indefinição de tarefas que se viveu nesse período, com o juiz da comarca a funcionar como 1supervisor de uma instrução conduzida pelo Ministério Público'. Entre esses diplomas citam-se o Dec-Lei no 321/76, de 4-05 (que atribui a direção da instrução preparatória aos juízes de instrução criminal), o Dec-Lei n $n^{\circ}$ 618/76, de 27-06 (atribui funções de juiz de instrução ao juiz da comarca limítrofe à competente), e o Dec-Lei $n^{\circ}$ 354/77, de 30-08 (que inverteu o sistema de intervenção consagrado no Dec-Lei $n^{\circ}$ 618/76). Sintomático da confusão, que então se viveu, é o Despacho Ministerial de 14-10-1976, o qual previa a intervenção dos substitutos do juiz da comarca (em regra, os Conservadores) como juízes de instrução.” (destaques do autor). (JACINTO, Francisco Teodósio. O modelo de processo penal entre o inquisitório e o acusatório: repensar a intervenção judicial na comprovação da decisão de arquivamento do inquérito. Disponível em: http://www.stj.pt/nsrepo/cont/Coloquios/TeodosioJacinto_vf.pdf. Acesso em 12-04-2011).

${ }^{232}$ "Em Portugal, o Ministério Público foi erigido à condição de magistratura autônoma (Constituição Federal portuguesa, 221, $\S \S 2^{\circ}$ e $3^{\circ}$ ), que, embora hierarquizada, atua com independência e em obediência à estrita legalidade, incumbindo-lhe colaborar com o tribunal a descoberta da verdade e na realização do direito, obedecendo em todas as manifestações os critérios de estrita objectividade (CPP português, art. 53, 1)". (destaques do autor). (DEMERCIAN, Pedro Henrique. Regime jurídico do ministério público no processo penal. São Paulo: Verbatim, 2009, p. 55). 
dependência funcional (CPPP, arts. 53, 2, b, e 263, 1 e 2).

Findo o inquérito, ao Ministério Público incumbe decidir pela acusação ou pelo arquivamento. Surge, então, a possibilidade de mais uma fase, a fase de instrução. A referida fase, que tem por objetivo "a comprovação judicial da decisão de deduzir acusação ou de arquivar o inquérito em ordem a submeter ou não a causa a julgamento" (art. 286, 1, do (PPP), somente poderá ser provocada pelo arguido, em caso de oferecimento de acusação, ou pelo assistente, em caso de arquivamento, a depender da provocação desses sujeitos processuais, no que se assenta sua facultatividade. ${ }^{233}$

A fase de instrução (artigos 286 a 310, do CPPP) abrange possíveis atos de instrução, debates instrutórios e uma decisão judicial instrutória que poderá consistir em pronúncia ou não pronúncia, conforme tenham sido recolhidos ou não, respectivamente, indícios suficientes de se terem verificado os pressupostos de que depende a aplicação ao arguido de uma pena ou de uma medida de segurança, avançando-se ou não para a fase de julgamento.

Ultimada a instrução ou, caso esta não tenha sido provocada, uma vez tendo o Ministerio Público decidido pela acusação, passa-se à fase de julgamento, que compreende os atos preliminares (artigos 311 a 320, do CPPP), como o saneamento do processo, e a audiência de julgamento (artigos 321 a 364, do CPPP), que é finalizada pela decisão.

Tecidas tais considerações, impende analisar os aspectos mais significativos da participação da vítima no processo penal português, relacionados ao controle sobre a acusação pública, a principiar pelo incidente de aceleração processual. Conforme dispõem os artigos 108 a 110, do CPPP, em caso de ter sido excedido o prazo legal para cada fase processual, poderá o assistente ${ }^{234}$ - assim como o Ministério Público, o arguido e as partes civis - suscitar o referido incidente, dirigindo-o ao procurador-geral da república, enquanto o processo se encontrar sob a direção do Ministério Público (fase de inquérito), ${ }^{235}$ permitindo-se um verdadeiro controle sobre o exercício da acusação pública em prazo razoável.

\footnotetext{
${ }^{233}$ Eis a crítica de DEMERCIAN a respeito: "A instauração facultativa de uma fase intermediária é criticada na Esposição de Motivos do Código de Processo Penal Tipo para a América Latina, sob o argumento de que não se poderia 'confiar o interesse que a administração da justiça estatal tem na realização de julgamentos corretos' ao arbítrio do particular. A crítica parece realmente apropriada. A instauração da fase intermediária não se reduz a uma mera estratégia de defesa. E, por outro lado, a rejeição de uma acusação temerária e infundada é interesse da própria sociedade". (DEMERCIAN, Pedro Henrique. Regime jurídico do ministério público no processo penal. São Paulo: Verbatim, 2009, p. 53).

${ }^{234}$ Sobre a figura do assistente, cf. item 5.3.1.3.

${ }^{235} \mathrm{O}$ procedimento de aceleração processual também poderá ser manejado durante a fase de processo, sob a condução do juiz ou tribunal, devendo ser proposto, nesse caso, perante o Conselho Superior da Magistratura.
} 
Quanto ao controle da vítima sobre o arquivamento do inquérito realizado pelo Ministério Público, faz-se necessário compreender que a legislação penal portuguesa concebe três categorias de crimes, às quais correspondem procedimentos específicos: os crimes públicos, os crimes semi-públicos e os crimes privados, conforme será examinado a seguir.

Os crimes públicos constituem maioria no ordenamento jurídico-penal lusitano. Ao adquirir a notícia do crime, por conhecimento próprio, ou por conhecimento provocado por denúncia ou por órgãos de polícia criminal, o Ministério Público pode instaurar o inquérito independentemente da vontade das vítimas ou de quem quer que seja.

Se durante o inquérito tiverem sido recolhidos indícios suficientes ${ }^{236}$ acerca da existência do crime e de sua autoria, o Ministério Público, no prazo de dez (10) dias, deduzirá acusação (art. 283, 1, do CPPP), prescindindo de qualquer consentimento alheio. $^{237}$

Caso o Ministério Público decida pelo arquivamento do inquérito com base nas hipóteses previstas no art. 277, 1 e 2, do CPPP, ${ }^{238}$ o fará por despacho, cujo teor deverá ser comunicado ao arguido, ao assistente, ao denunciante com faculdade de se constituir assistente e a quem tenha manifestado o propósito de deduzir pedido de indenização civil, bem como ao respectivo defensor ou advogado (art. 277, 3, do CPPP).

Se o assistente discordar do arquivamento, poderá requerer a abertura da fase de instrução (art. 287, 1, b, do CPPP), ocasião em que caberá ao juiz da instrução pronunciar ou não, exercendo um controle judicial sobre o arquivamento. Segundo TEODÓSIO JACINTO, “tal requerimento só poderá ser rejeitado por extemporâneo, por incompetência do juiz ou inadmissibilidade legal da instrução - $\operatorname{artigos} 286^{\circ} \mathrm{n}^{\circ} 1$ e $287^{\circ} 1$, b) 3 do C. P. Penal.,"239

$\mathrm{O}$ assistente, assim como o denunciante com a faculdade de constituir-se assistente, se não optar pelo exercício do referido mecanismo de controle judicial, pode

\footnotetext{
236 "Consideram-se suficientes os indícios sempre que deles resultar uma possibilidade razoável de ao arguido vir a ser aplicada, por força deles, em julgamento, uma pena ou uma medida de segurança" (art. 283, 2, do CPPP).

${ }^{237}$ Conforme já referido, neste caso, o arguido poderá opor-se à acusação, solicitando a abertura de instrução perante o juiz (art. 287, 1, $a$, do CPPP).

238 “1 - O Ministério Público procede, por despacho, ao arquivamento do inquérito, logo que tiver recolhido prova bastante de se não ter verificado crime, de o arguido não o ter praticado a qualquer título ou de ser legalmente inadmissível o procedimento. 2 - O inquérito é igualmente arquivado se não tiver sido possível ao Ministério Público obter indícios suficientes da verificação de crime ou de quem foram os agentes."

239 JACINTO, Francisco Teodósio. O modelo de processo penal entre o inquisitório e o acusatório: repensar a intervenção judicial na comprovação da decisão de arquivamento do inquérito. Disponível em: <http://www.stj.pt/nsrepo/cont/Coloquios/TeodosioJacinto_vf.pdf>. Acesso em: 12 abr. 2011, p. 16.
} 
valer-se de um mecanismo de controle hierárquico (a intervenção hierárquica). Conforme o art. 288, 1 e 2, do CPPP, no prazo de vinte (20) dias a contar da data em que a abertura de instrução já não puder ser requerida, o imediato superior hierárquico do magistrado do Ministério Público pode, por sua iniciativa ou a requerimento do assistente ou do denunciante com a faculdade de se constituir assistente, determinar que seja formulada acusação ou que as investigações prossigam, indicando, neste caso, as diligências a efetuar e o prazo para o seu cumprimento.

Nos crimes semi-públicos, o legislador passa a exigir a apresentação de queixa (equivalente à representação nas ações penais de iniciativa pública condicionada à representação do processo penal brasileiro). Embora se cuide de uma condição de procedibilidade, e como tal, imprescindível para a promoção do processo pelo Ministério Público, a queixa a este não vincula, ou seja, não torna obrigatória ipso facto a dedução de acusação pública. O procedimento para esses crimes, previsto no art. 49 , do $\operatorname{CPPP}^{240}$ não difere do procedimento para os crimes públicos, analisado nos parágrafos anteriores, inclusive em relação à possibilidade de controle sobre o despacho de arquivamento, limitando-se o art. 49 a disciplinar o exercício de queixa.

Restam, por fim, os crimes privados, escassos no Código Penal lusitano e que envolvem alguns dos crimes contra a honra. ${ }^{241}$ Para tais crimes, o CPPP prevê um rito específico, o procedimento dependente de acusação particular (arts. 50 e 285, do CPPP). ${ }^{242}$

Consoante FERNANDO FERNANDES, "apresentada e recebida queixa, contendo a declaração de posterior constituição de assistente, o ministério público adquire

\footnotetext{
240 "1 - Quando o procedimento criminal depender de queixa, do ofendido ou de outras pessoas, é necessário que essas pessoas dêem conhecimento do facto ao Ministério Público, para que este promova o processo. 2 - Para o efeito do número anterior, considera -se feita ao Ministério Público a queixa dirigida a qualquer outra entidade que tenha a obrigação legal de a transmitir àquele. 3 - A queixa pode ser apresentada pelo titular do direito respectivo, por mandatário judicial ou por mandatário munido de poderes especiais. $4-\mathrm{O}$ disposto nos números anteriores é correspondentemente aplicável aos casos em que o procedimento criminal depender da participação de qualquer autoridade."

${ }^{241}$ Cf. FERNANDES, Fernando. O processo penal como instrumento de política criminal. Coimbra: Almedina, 2008. (Coleção teses), p. 437.

242 "Artigo 50. 1 - Quando o procedimento criminal depender de acusação particular, do ofendido ou de outras pessoas, é necessário que essas pessoas se queixem, se constituam assistentes e deduzam acusação particular. 2 - O Ministério Público procede oficiosamente a quaisquer diligências que julgar indispensáveis à descoberta da verdade e couberem na sua competência, participa em todos os actos processuais em que intervier a acusação particular, acusa conjuntamente com esta e recorre autonomamente das decisões judiciais. 3 -É correspondentemente aplicável o disposto no n. ${ }^{\circ} 3$ do artigo anterior."

"Artigo 285. 1 - Findo o inquérito, quando o procedimento depender de acusação particular, o Ministério Público notifica o assistente para que este deduza em 10 dias, querendo, acusação particular. $2-\mathrm{O}$ Ministério Público indica, na notificação prevista no número anterior, se foram recolhidos indícios suficientes da verificação do crime e de quem foram os seus agentes. 3 -É correspondentemente aplicável à acusação particular o disposto nos n.os 3 e 7 do artigo $283 .^{\circ} 4-\mathrm{O}$ Ministério Público pode, nos cinco dias posteriores à apresentação da acusação particular, acusar pelos mesmos factos, por parte deles ou por outros que não importem uma alteração substancial daqueles."
} 
legitimidade para promover o procedimento e, em consequência, realizar as diligências de inquérito." 243

Concluído o inquérito, dirigido pelo Ministério Público, este notificará o assistente para que deduza em dez (10) dias, se o quiser, a acusação particular, no que até cinco (05) dias após a apresentação de tal acusação, poderá o Ministério Público oferecer acusação pública, pelos mesmos fatos, por parte deles ou por outros, desde que não implique uma alteração substancial daqueles. Vê-se, assim, a inversão de papéis entre Ministério Público e assistente, quanto ao procedimento de acusação próprio de crimes públicos (e semi-públicos).

Caso o assistente não apresente sua acusação no prazo legal, ao Ministério Público somente restará determinar o arquivamento do inquérito, já que não poderá oferecer acusação pública sem que haja a prévia acusação particular.

\subsection{Argentina}

A Argentina apresenta uma organização federativa, dividindo-se em vinte e três (23) províncias e uma (01) cidade autônoma (Buenos Aires).

O sistema de justiça penal argentino segue essa orientação federativa. Assim, no âmbito nacional (federal), existem o Poder Judiciário (Poder Judicial de la Nación) e o Ministério Público (Ministerio Público Fiscal de la República Argentina ou Ministerio Público Fiscal de la Nación) - que também atuam na cidade autônoma de Buenos Aires e no âmbito provincial, cada província conta com seu Poder Judiciário e Ministério Público respectivos.

Da mesma forma, existem em vigor vários códigos processuais penais no território argentino, o Codigo Procesal de la Nación (CPPN), em âmbito nacional (federal), e os códigos locais, que vigem nas respectivas províncias, registrando-se o detalhe de que a cidade autônoma de Buenos Aires também conta com seu próprio código.

Neste estudo, a fim de se facilitar a abordagem, tendo em vista a diversidade de institutos processuais decorrente desse universo de normas processuais, serão tratadas apenas as disposições referentes ao Código Procesal de la Nación (CPPN), fazendo-se

243 FERNANDES, Fernando. O processo penal como instrumento de política criminal. Coimbra: Almedina, 2008. (Coleção teses), p. 438. 
referência ao Poder Judiciário e ao Ministério Público nacionais (federais) argentinos.

A fim de substituir o Código de Procedimiento Criminal de la Nación, de 1888, e após tentativas de reforma na década de $80,{ }^{244}$ aprovou-se o CPPN (Lei 23.984) em 09 de setembro de 1991, entrando em vigência na data de 05 de setembro de 1992. Esse diploma legal insistiu em um sistema inquisitorial, porém, com algumas atenuações, que também pode ser tratado como um sistema misto, o que mereceu o comentário de DANIEL PASTOR, de que o código já teria nascido velho e caduco. ${ }^{245}$

Nesse sentido, o CPPN mantém uma etapa denominada de instrução, ${ }^{246}$ que ficará, via de regra, a cargo do juiz da instrução (juez de instrucción). Consoante seu art. 194, o "juez de instrucción deberá proceder directa e inmediatamente a investigar los hechos que aparezcan cometidos en su circunscripción judicial, sin perjuicio de lo dispuesto en el artículo 196." A ressalva referida (artigo 196) estabelece a polêmica faculdade de o juiz da instrução delegar a direção das investigações ao Ministério Público (Ministerio Público Fiscal, ou simplesmente, MPF).

Tal faculdade não tinha qualquer previsão no projeto original do $C P P N-\mathrm{o}$ Projeto Levene - tendo sido acrescida em razão de intervenção do Ministro da Justiça, León Arslanian, em face das críticas políticas e acadêmicas ao projeto.

A confusão aumentou em razão de reformas posteriores que tinham por norte o

\footnotetext{
244 Entre 1984 e 1986, houve uma tentativa de reforma na legislação processual penal federal (nacional) que visava a substituir o sistema inquisitorial pelo sistema acusatório. Todavia, não houve êxito em razão de resistências corporativas e entraves políticos. (ARDUÍNO, Ileana; LITVACHKY, Paul; MAXIT, Margarita. O Ministério público na Argentina. Tradução de Victor Ferreira. In: DIAS, João Paulo; AZEVEDO, Rodrigo Ghiringhelli de. (Coord.). O papel do ministério público: estudo comparado dos países latino-americanos. Coimbra: Almedina, 2008. p. 247-308, p. 253).

${ }^{245}$ Sobre as colocações de PASTOR: "Pastor retira esta frase de um comentário de um processualista argentino, Velez Mariconde, sobre o processo de reforma argentina de 1888. Manuel Obarrio, autor dessa reforma, usou como modelo a antiga legislação inquisitória espanhola de 1879. No entanto, essa legislação já tinha sido abandonada por Espanha em 1882 (2004a:214). O modelo do Código do Processo Penal de 1991 foi o Código de 1939 da província argentina de Córdoba. Mas nessa altura já a província de Córdoba tinha adoptado um novo Código do Processo Penal com um sistema acusatório formal. É de notar o comportamento histórico repetitivo da justiça nacional e federal argentina de aprovar códigos de processo penal 'velhos e caducos'." (ARDUÍNO, Ileana; LITVACHKY, Paul; MAXIT, Margarita. O Ministério público na Argentina. Tradução de Victor Ferreira. In: DIAS, João Paulo; AZEVEDO, Rodrigo Ghiringhelli de. (Coord.). O papel do ministério público: estudo comparado dos países latino-americanos. Coimbra: Almedina, 2008. p. 247-308, p. 254).

246 “Art. 193. - La instrucción tendrá por objeto: $1^{\circ}$ ) Comprobar si existe un hecho delictuoso mediante las diligencias conducentes al descubrimiento de la verdad. $2^{\circ}$ ) Establecer las circunstancias que califiquen el hecho, lo agraven, atenúen o justifiquen, o influyan en la punibilidad. $3^{\circ}$ ) Individualizar a los partícipes. $\left.4^{\circ}\right)$ Verificar la edad, educación, costumbres, condiciones de vida, medios de subsistencia y antecedentes del imputado; el estado y desarrollo de sus facultades mentales, las condiciones en que actuó, los motivos que han podido determinarlo a delinquir y las demás circunstancias que revelen su mayor o menor peligrosidad. $\left.5^{\circ}\right)$ Comprobar la extensión del daño causado por el delito, aunque el damnificado no se hubiera constituido en actor civil."
} 
sistema acusatório. ${ }^{247}$ Assim, a Lei 25.409 , de 20 de abril de 2001 acrescentou ao CPPN os arts. 196 bis, 196 ter, e 196 quater, que, dentre outras inovações, determinaram que, caso não haja individualização da autoria, a direção da investigação deverá desde o início competir (ser delegada) ao $M P F$, com notificação do juiz de instrução. A Lei 25.760, de 11 de agosto de 2003, por sua vez, acrescentando um parágrafo ao art. 196 bis, determinou que nos casos previstos nos arts. 142 bis e 170, do Código Penal nacional, inclusive havendo conexão de crimes, ainda que a autoria esteja individualizada, cabe ao $M P F$ iniciar as investigações, também com notificação do juiz de instrução.

A existência de um juiz de instrução, ainda que compensada por um mecanismo de delegação, gera críticas acerbas da literatura jurídica ${ }^{248}$, todavia, continua em vigência.

O juiz de instrução, ao final das investigações, dará vistas às partes que poderão propor diligências, requerer a elevación a juicio ou o arquivamento. Caso discorde do pedido de arquivamento do $M P F$, o juiz submeterá o caso à Câmara de Apelações que, na hipótese de confirmar a decisão do juiz de instrução, remeterá os autos a outro membro do $M P F$ (arts. 346 a 353, do $C P P N)$.

Caso seja acatada a elevación a juicio, se dará início à fase de debates orais e de julgamento, o juicio comum ou rito ordinário, que é marcado pela oralidade e seus princípios correlatos, ultimando-se com a decisão (arts. 354 a 404, do CPPN).

Quanto ao controle que a vítima pode exercer sobre a acusação pública, em face da literalidade do art. 348, do $C P P N,{ }^{249}$ mostra-se pacífico que caso o $M P F$ solicite o arquivamento e a vítima, constituída como querellante particular, ${ }^{250}$ ao contrário, requeira

\footnotetext{
${ }^{247}$ Cf. ARDUÍNO, Ileana; LITVACHKY, Paul; MAXIT, Margarita. O Ministério Público na Argentina. Tradução de Victor Ferreira. In: DIAS, João Paulo; AZEVEDO, Rodrigo Ghiringhelli de. (Coord.). O papel do ministério público: estudo comparado dos países latino-americanos. Coimbra: Almedina, 2008. p. 247308 , p. 255.

${ }^{248}$ HEREDIA, com base em julgamento da Corte Suprema de Justicia de la Nación - que adota o entendimento de que toda vez que haja definição constitucional expressa (nacional ou provincial) de incumbência ao Ministério Público da persecução, tal atribuição não pode ser conferida a outro Poder afirma que o juiz de instrução viola o paradigma constitucional do processo penal, o mesmo ocorrendo em relação a um $M P F$ passivo que se limita a requerer sem assumir a titularidade da persecução penal. Conferir a análise completa em: HEREDIA, José Raúl. Lectura constitucional del proceso penal. Córdoba: Ediciones del Copista, 2010, p. 69-84.

249 “Art. 348. - Si la parte querellante y el agente fiscal solicitaren diligencias probatorias, el juez las practicará siempre que fueren pertinentes y útiles y, una vez cumplidas, les devolverá el sumario para que se expidan, conforme al inciso 2 del artículo anterior. El juez dictará sobreseimiento si estuviere de acuerdo con el requerido. De lo contrario, sea que no esté de acuerdo con el sobreseimiento pedido por el fiscal o sea que sólo el querellante estimara que debe elevar la causa a juicio, dará intervención por seis (6) días a la Cámara de Apelaciones. Si ésta entiende que corresponde elevar la causa a juicio, apartará al fiscal interviniente e instruirá en tal sentido al fiscal que designe el fiscal de Cámara o al que siga en orden de turno". (destaques nossos).

${ }^{250}$ Sobre referido instituto cf. item 5.3.1.4.
} 
a elevación a juicio, deverá o juiz da instrução submeter o caso à Cámara de Apelaciones, ${ }^{251}$ a quem caberá a decisão. Caso se acolha o pleito da vítima, será afastado o fiscal que requereu o arquivamento, prosseguindo-se o feito com a atuação do fiscal de Camara.

4.3.2.2 Lineamentos para um controle mais efetivo com participação da vítima

Conforme já analisado, o ordenamento jurídico brasileiro prevê como hipóteses de controle sobre o ius accusationis estatal: um controle efetuado pelo juiz da causa sobre o arquivamento (Código de Processo Penal, art. 28), e outra consistente em um controle efetuado pela vítima tão-somente sobre a inércia do Ministério Público em adotar providências dentro do prazo conferido a este para tanto: a ação penal de iniciativa privada subsidiária. $^{252}$

Se a primeira hipótese se mostra frequente na praxe forense, embora não conte com qualquer participação da vítima, esta última, não obstante poder ser exercida pela vítima, raramente o é na prática, o que se deve significativamente aos custos na promoção da persecução penal pelo particular e à ausência de poderes investigatórios por parte deste.

Acerca do controle sobre o ius accusationis, o Código projetado, no texto cuja redação foi aprovada pelo Senado, não traz qualquer inovação substancial, prevendo apenas a notificação da vítima, caso o juiz efetivamente proceda ao arquivamento pretendido pelo Ministério Público, o que serve àquela como mera cientificação de que a promoção ministerial restou acolhida pelo juiz, importando na não aplicação do procedimento previsto no art. 28 do Código de Processo Penal.

Como se vê, a configuração atual e projetada dessa modalidade de participação da vítima carece, em nosso ordenamento jurídico, de uma necessária reestruturação. Tal deficiência entra em contraste com os ordenamentos jurídicos estrangeiros examinados neste trabalho, que se destacam por oferecer diversos mecanismos que viabilizam o controle da acusação pública pela vítima. E serão justamente esses mecanismos que

${ }^{251} \mathrm{O}$ que também pode fazer o juiz de ofício.

252 Outro mecanismo seria o recurso administrativo que pode ser interposto pelo legítimo interessado conceito em que se pode incluir a vítima - junto ao Colégio de Procuradores de Justiça (art. 12, inciso XI, da Lei n. 8625/93). Todavia, esse recurso, conforme já se asseverou, além de depender de regulamentação na lei orgânica de cada Ministério Público, não pode ser manejado em todos os casos, mas somente quando se trata de arquivamento em sede de ação penal de iniciativa pública originária. 
poderão servir como referência para a construção de um modelo próprio.

Em uma rápida visão sobre tais ordenamentos jurídicos alienígenas, pode-se registrar que, na Alemanha, existe um controle inicialmente hierárquico e, em caso de denegação, um controle posteriormente judicial; na Argentina, caso o MPF solicite o arquivamento e o querellante particular, ao contrário, requeira a elevación a juicio, deverá o juiz da instrução submeter o caso à Cámara de Apelaciones, à qual caberá a decisão; na Itália, a par da possibilidade de requerer a avocação das investigações pelo procuradorgeral, em caso de inércia, a vítima poderá opor-se fundamentadamente ao arquivamento requerido pelo Pubblico Ministero, o que ensejará a adoção de procedimento específico pelo giudice per le indagini preliminari - a camera di consiglio - no qual será decidido se as investigações serão ou não arquivadas; em Portugal, além da possibilidade de suscitar a aceleração processual ao procurador-geral da república, caso o magistrado do Ministério Público exceda os prazos na fase de investigação, o assistente poderá, em caso de arquivamento, requerer a abertura da fase de instrução, na qual o juiz da instrução determinará a pronúncia do arguido - rejeitando o arquivamento em decisão irrecorrível ou sua impronúncia - acolhendo o arquivamento, bem como se faculta ao assistente a provocação da intervenção hierárquica, caso em que a revisão sobre o arquivamento será decidida pelo próprio chefe da magistratura do Ministério Público.

Advirta-se que essas soluções legislativas, embora apresentem uma postura de acolhimento aos interesses das vítimas de infração penal, não poderão simplesmente ser trasladadas ao ordenamento jurídico brasileiro, sob pena de, uma vez retiradas de seu contexto jurídico, e implementadas abruptamente em uma ordem jurídica estranha, virem a sofrer uma reação de inconstitucionalidade ou mesmo ensejarem um rechaço pela cultura jurídica brasileira.

Surge, então, o questionamento: o que poderia se fazer em nosso ordenamento jurídico em prol da vítima, à vista de tais mecanismos de controle existentes no direito comparado? As soluções devem ser apontadas em relação ao controle sobre a inércia ministerial e quanto ao controle sobre o arquivamento.

Quanto ao controle sobre a inércia do órgão acusatório, como já asseverado, sobressai no atual ordenamento jurídico a possibilidade de a vítima ajuizar ação penal de iniciativa privada subsidiária, mecanismo cujos incômodos já restaram relatados, mas que podem ser atenuados em razão de uma atuação mais vigorosa da Defensoria Pública, cuja estrutura e quadro de pessoal precisariam de uma maior atenção do Poder Público, urgindo, para tanto, a promoção de uma política de assistência judiciária em âmbito nacional. 
De fato, a Defensoria Pública, conforme dispõe a Lei Complementar n. 80/94, em seus arts. 44, X e 128, X, goza de poder de requisição junto à autoridade pública e seus agentes, o qual pode ter por objeto certidões, perícias, vistorias, diligências, processos, documentos, informações, esclarecimentos e providências necessárias ao exercício de suas atribuições, dentre as quais, a futura promoção de ação penal de iniciativa privada subsidiária (art. $\left.4^{\circ}, \mathrm{XV}\right)$.

Esse panorama legal permite o enfrentamento jurídico das desvantagens da ação subsidiária - ao menos para o hipossuficiente -, a saber, o custo econômico de tal patrocínio, visto que se cuida de serviço público gratuito, e a possibilidade de ajuizamento de ação temerária, considerando que o juízo de propositura de tal ação caberá a agente político, ao qual, dentre as prerrogativas estabelecidas em Lei, assegura-se a prerrogativa de não patrocinar ação, quando esta for manifestamente incabível ou inconveniente aos interesses da parte sob seu patrocínio, comunicando e justificando o fato ao Defensor Público-Geral (Lei Complementar n. 80/94, arts. 44, XII e 128, XII).

No que concerne ao controle sobre o arquivamento, há de se afastar as soluções legislativas alienígenas que permitam ao Poder Judiciário, por requerimento da vítima, não acolher o arquivamento requerido pelo Ministerio Público e determinar o oferecimento de denúncia por órgão deste. A adoção de tais soluções enseja um verdadeiro ataque à essência do princípio acusatório, que estipula a necessária divisão das funções de acusar e de julgar (Constituição Federal, art. 129, inciso I).

Por outro lado, os procedimentos preconizados nas legislações alemã, italiana, portuguesa e argentina conferem às vítimas de infração penal o exercício do controle sobre o arquivamento, o que não ocorre na legislação brasileira. De fato, o art. 28, do Código de Processo Penal, além de não abrir qualquer espaço para a participação das vítimas, institui uma função não jurisdicional a cargo do Poder Judiciário: a de fiscalizar o princípio da obrigatoriedade da ação penal pública. Essa função, além de ser marcada pela peculiaridade de reduzir a atividade do juiz a de um mero provocador externo de revisão administrativa no âmbito do Ministério Público, sem qualquer poder de decisão no caso, ${ }^{253}$ causa ainda o grave incômodo de afetar a imparcialidade do juiz que venha a aplicar o

\footnotetext{
${ }^{253}$ De fato, o Poder Judiciário, no exercício do disposto do art. 28, do Código de Processo Penal, serve apenas de agente provocador da instância ministerial superior, não lhe cabendo exercer função jurisdicional no caso. A última palavra, como já se disse, é do procurador-geral, que ao insistir no arquivamento, oferece um requerimento de arquivamento que vincula o Poder Judiciário ao acatamento. Esse papel secundário fica ainda mais evidente quando se trata de ação penal originária que tramita perante os tribunais, pois em tais casos, mesmo que haja discordância da parte do tribunal, este nada poderá fazer além de acatar o pedido de arquivamento formulado pelo procurador-geral.
} 
referido dispositivo legal, em razão de manifestar-se este a favor da instauração da ação penal.

A solução para o problema, assim, deve guiar-se pela necessidade de adoção de um mecanismo de revisão sobre o arquivamento promovido pelo promotor em que se dê o afastamento do Poder Judiciário e, por outro lado, em que se permita uma participação decisiva das vítimas da infração penal.

A proposta inicialmente trazida pela comissão de juristas encarregada de elaborar o projeto de um novo Código de Processo Penal, tal qual constante no texto original do referido projeto (PLS n. 156/09), atendia a esses requisitos, embora tenha sido rejeitada durante a tramitação desse projeto, desaparecendo do texto final aprovado no Senado. ${ }^{254}$

Consoante os arts. 37 e 38 do Projeto n. 156/09, ${ }^{255-256}$ cabia ao promotor determinar o arquivamento do inquérito policial. Uma vez ordenado tal arquivamento, o Ministério Público deveria comunicá-lo à vítima, ao investigado, à autoridade policial e à instância de revisão do próprio órgão ministerial. Se a vítima, ou seu representante legal, não concordasse com o arquivamento, poderia, no prazo de trinta (30) dias do recebimento da comunicação, submeter a matéria à revisão da instância administrativa competente. ${ }^{257}$

\footnotetext{
${ }^{254}$ Como já referido inicialmente, o texto final do projeto aprovado no Senado praticamente repete o disposto no art. 28 do atual Código, acrescentando apenas que ao arquivar o inquérito, o juiz comunicará tal ato à vítima, ao investigado e ao delegado de polícia.

255 “Art. 37. Compete ao Ministério Público determinar o arquivamento do inquérito policial, seja por insuficiência de elementos de convicção ou por outras razões de direito, seja, ainda, com fundamento na provável superveniência de prescrição que torne inviável acaplicação da lei penal no caso concreto, tendo em vista as circunstâncias objetivas e subjetivas que orientarão a fixação da pena".

256 “Art. 38. Ordenado o arquivamento do inquérito policial ou de quaisquer elementos informativos da mesma natureza, o Ministério Público comunicará a vítima, o investigado, a autoridade policial e a instância de revisão do próprio órgão ministerial, na forma da lei. $§ 1^{\circ}$ Se a vítima, ou seu representante legal, não concordar com o arquivamento do inquérito policial, poderá, no prazo de 30 (trinta) dias do recebimento da comunicação, submeter a matéria à revisão da instância competente do órgão ministerial, conforme dispuser a respectiva lei orgânica. $\S 2^{\circ}$ Nas ações penais relativas a crimes praticados em detrimento da União, Estados, Distrito Federal e Municípios, a revisão do arquivamento do inquérito policial poderá ser provocada pela chefia do órgão a quem couber a sua representação judicial”.

${ }^{257}$ Eis o trecho relativo à matéria, constante na exposição de motivos da comissão: "Do mesmo modo, retirou-se, e nem poderia ser diferente, o controle judicial do arquivamento do inquérito policial ou das peças de informação. No particular, merece ser registrado que a modificação reconduz o juiz à sua independência, na medida em que se afasta a possibilidade de o Ministério Público, na aplicação do art. 28 do atual Código, exercer juízo de superioridade hierárquica em relação ao magistrado. O controle do arquivamento passa a se realizar no âmbito exclusivo do Ministério Público, atribuindo-se à vítima legitimidade para o questionamento acerca da correção do arquivamento. $\mathrm{O}$ critério escolhido segue a lógica constitucional do controle de ação penal pública, consoante o disposto no art. $5^{\circ}$, LIX, relativamente à inércia ou omissão do Ministério Público no ajuizamento tempestivo da pretensão penal. Decerto que não se trata do mesmo critério, mas é de se notar a distinção de situações: a) no arquivamento, quando no prazo, não há omissão ou morosidade do órgão público, daí porque, cabendo ao Ministério Público a titularidade da ação penal, deve o juízo acusatório, em última instância, permanecer em suas mãos; b) na ação penal subsidiária, de iniciativa privada, a legitimidade da vítima repousa na inércia do órgão ministerial, a autorizar a físcalização por meio
} 
Esse mecanismo projetado, entretanto, não trazia uma solução expressa para os casos em que se tratasse de crimes de vítimas difusas ou indeterminadas. Em razão da maior repercussão social que decorre de infrações penais de tal natureza, poder-se-ia admitir, para tais casos, a remessa obrigatória da decisão de arquivamento do inquérito policial pelo promotor de justiça, acompanhado das cópias dos autos, à instância administrativa revisora, procedimento que se deflagraria, assim, independentemente da provocação de agentes externos.

As considerações aqui propostas, como se pode observar, esforçam-se por aliar mais efetividade a uma maior participação da vítima, afastando-se do Judiciário a problemática função anômala de fiscalização sobre o princípio da obrigatoriedade da ação penal.

\subsection{REPARAÇÃO DE DANOS CIVIS}

\subsubsection{A reparação de danos civis no atual processo penal brasileiro}

Preliminarmente, cumpre asseverar que o tema da reparação de danos civis será aqui discorrido sob o enfoque exclusivo da efetiva atuação da vítima no processo penal com a finalidade de obter a reparação do dano civil ex delicto, no que serão analisadas as respectivas hipóteses de participação da vítima com tal intuito. ${ }^{258}$

Deve-se ainda, de antemão, esclarecer que ao se defender aqui que a intervenção da vítima no processo penal não pode ser condicionada à existência de um interesse de reparação em sentido patrimonialista, sob pena de se permitir uma visão drasticamente reducionista de seu direito à participação, não se deve, por outro lado, desconsiderar a importância que os interesses de natureza civil podem representar para a vítima, de tal modo que a lei deve disponibilizar-lhe mecanismos hábeis à efetiva satisfação de interesses de tal ordem.

da submissão do caso ao Judiciário". (Disponível em: <http://legis.senado.gov.br/mate-pdf/58503.pdf>. Acesso em: 21 out. 2010).

${ }^{258}$ Assim, institutos que viabilizem a reparação de danos civis em prol da vítima, mas que não contem com efetiva participação processual da vítima não merecerão maior consideração neste tópico, como o instituto do arrependimento posterior, previsto no art. 16, do Código Penal, ou a mera obtenção do título executivo judicial como mero efeito da sentença condenatória penal. 
Tecido esse esclarecimento, não se pode perder de vista que o tema da reparação de danos no processo penal encontra-se indiscutivelmente atrelado ao fenômeno da incidência múltipla.

Quanto a esse fenômeno, CABRAL destaca que um mesmo fato jurídico pode repercutir e produzir consequências jurídicas em diversas esferas: penal, civil, administrativa. De tal modo que, "quando praticado um crime, além da repressão através da pena, pode ser cabível sanção administrativa ou disciplinar, e também a reparação do dano causado à vítima.",259

ARAKEN DE ASSIS aponta para um quadro geral de soluções que o direito comparado encontra para o problema da incidência múltipla, o qual exibe uma "face universal e, por isso, nenhum ordenamento se mostra infenso a grau mínimo de coordenação penal e civil”. ${ }^{260}$

Assim, não obstante as dificuldades de sistematização atribuível aos nacionalismos, e pondo-se de lado ressalvas e esperanças de rigidez simétrica, o autor cita inicialmente quatro sistemas distintos para lidar com tal fenômeno: separação, em que o provimento penal exerceria nenhuma ou limitadíssima influência na área civil; confusão: quando uma única ação serve para o duplo objetivo de aplicar a pena e reparar o dano; solidariedade: em que, separadas as ações, obrigatoriamente se resolveriam juntas e no mesmo processo; livre escolha: em que se daria a cumulação facultativa de ambas as ações no processo penal.

Ao final, ARAKEN DE ASSIS, após considerar a inexistência, em sua pureza, dos sistemas da solidariedade e da confusão, conclui pela existência de apenas dois sistemas: separação e adesão, abrigando este dupla compartimentação, no que se refere à obrigatoriedade da demanda conjunta ou a faculdade de opção pela via civil. ${ }^{261}$

\footnotetext{
${ }^{259}$ CABRAL, Antônio do Passo. O valor mínimo da indenização cível fixado na sentença condenatória penal: notas sobre o novo art. 387, IV do CPP. Revista da EMERJ. Rio de Janeiro, v. 13, n. 49, p. 302-328, jan./mar. 2010, p. 302. Sobre o tema, leciona ARAKEN DE ASSIS: "Nada obsta ao mesmo fato ou complexo de fatos, como ensina a experiência comum, integrar elementos do suporte fático de duas ou mais regras. Conseguintemente, entram no mundo jurídico mediante várias aberturas, criadas pela diversidade de normas, que de seu lado, denotam as incontáveis opções axiológicas do ordenamento. Designa-se isto de incidência múltipla. Por esse motivo, a morte da pessoa abre a sucessão e transmite a posse e o domínio aos herdeiros (art. 1.572 do Cód. Civil de 1917), extingue a punibilidade, relativamente aos delitos por ela porventura praticados (art. 107, I, do Cód. Penal), e também enseja a suspensão da demanda civil em que figure como parte (art. 265, I, do Cód. de Proc. Civil), ou a própria extinção do processo (art. 267, IX, do Cód. de Proc. Civil), nas hipóteses de intransmissibilidade da ação.” (ASSIS, Araken de. Eficácia civil da sentença penal. 2. ed. rev. atual. amp. São Paulo: Revista dos Tribunais, 2000, p. 17).

${ }^{260}$ ASSIS, Araken de. Eficácia civil da sentença penal. 2. ed. rev. atual. amp. São Paulo: Revista dos Tribunais, 2000, p. 43.

261 ASSIS, Araken de. Eficácia civil da sentença penal. 2. ed. rev. atual. amp. São Paulo: Revista dos Tribunais, 2000, p.43-44. A respeito, a doutrina de DIAS: “[...]. Ultrapassado que foi, porém, o estádio
} 
Tornando de volta ao ordenamento jurídico brasileiro, percebe-se que nas Ordenações Filipinas, de 1603, que vigoraram por mais de dois séculos, abraçava-se a ideia de vingança pública, em prol da supremacia do soberano. Sob tais ordenações, as ideias de reparação, pena e multa ainda eram por demais confusas. ${ }^{262}$

Somente com a Constituição Imperial de 1824, é que se aboliram os principais mecanismos de vingança pública, abrindo-se espaço para a edição dos Códigos Civil e Criminal. $^{263}$

Sobreveio, pois, o Código Criminal do Império, de 1830, que adotou o sistema da adesão facultativa, seguindo-se o da adesão obrigatória, por força do Código de Processo Criminal de 1832.

A Lei n. 261, de 03.12.1841, adotou o sistema da separação, o qual após o hiato advindo da autonomia legislativa processual dos Estados, preconizada na Constituição Federal de 1891, foi reproduzido no Código Civil de 1916 (art. 1525), complementado pelo Código de Processo Penal, de 1941 (art. 63), e pelo Código de Processo Civil, de 1973 (art. 584, inciso III). ${ }^{264}$

$\mathrm{O}$ atual panorama jurídico-processual aponta para uma tendência cada vez mais forte de superação do sistema da separação em busca do sistema da adesão facultativa. Senão, veja-se: ao ofendido apresentavam-se, tradicionalmente, em face da cominação do disposto no Código Civil (de 2002), art. 935, Código de Processo Penal, arts. 63, 65 e 66, e Código Penal, art. 91, inciso I, duas opções: o ajuizamento independente de ação própria no juízo cível (a ação civil ex delicto) ou a obtenção do título executivo judicial, por eventual condenação penal do acusado (podendo o ofendido habilitar-se como assistente ou apenas aguardar o trâmite do processo).

Ocorre que inovações posteriores mitigaram ainda mais o sistema da separação. A primeira consistiu na possibilidade, contemplada pela Lei n. 9.099/95, art.

primitivo de 'confusão' entre o processo penal e civil, enquanto algumas legislações aceitavam um sistema de absoluta independência dos dois processos - e é a orientação mais arraigadamente individualista, por isso mesmo tradicional nos direitos anglo-saxônicos -, a maioria delas virava-se para a concepção de diversos sistemas de adesão, tendo como traço comum e essencial a possibilidade (ou mesma a obrigatoriedade) de juntar a acção civil ao processo penal, permitindo (ou impondo) que a jurisdição penal se pronuncie, ao menos em certa medida, sobre o objecto da acção civil. A razão de ser de tal sistema estaria na natureza 'tendencionalmente absorvente do facto que dá causa às duas acções', em atenção aos 'efeitos úteis que, do ponto de vista penal, se ligam à indemnização civil."' (DIAS, Jorge de Figueiredo. Direito processual penal. 1. ed. 1974, reimpressão. Coimbra: Coimbra editora, 2004, p. 540-541).

${ }^{262}$ FERNANDES, Antônio Scarance; MARQUES, Oswaldo Henrique Duek. O Estado na reparação do dano à vítima do crime. Justitia, São Paulo, v. 53, n. 156, p. 25-34, p. 26. out./dez. 1991.

${ }^{263}$ FERNANDES, Antônio Scarance. O papel da vítima no processo criminal. São Paulo: Malheiros, 1995 , p. 27.

264 ASSIS, Araken de. Eficácia civil da sentença penal. 2. ed. rev. atual. amp. São Paulo: Revista dos Tribunais, 2000, p. 46-49. 
74, de, em infrações de pequeno potencial ofensivo, o ofendido e o autor do delito celebrarem composição civil de danos perante o juízo penal, a qual, uma vez homologada, adquire natureza de título executivo judicial. Esse mecanismo, diga-se de passagem, constitui verdadeira revolução no processo penal brasileiro, não obstante se encontre jungido ao microssistema das infrações penais de pequeno potencial ofensivo.

A segunda inovação fez-se sentir recentemente, por força da Lei $n$. 11.719/2008, que modificou a redação dos arts. 387, inciso IV, e 63, p.u., passando-se a admitir a indenização ex officio pelo juízo penal, quanto ao dano ex delicto, mediante a fixação de um valor mínimo em prol da vítima.

Essa norma, porém, tem suscitado bastante polêmica. De fato, transforma em regra geral $^{265}$ o arbitramento de indenização pelo juiz, como poder-dever deste, ${ }^{266}$ independentemente de provocação do ofendido. ${ }^{267}$

Referido poder-dever, em que pese ofereça a vantagem para a vítima de obter, no processo penal, um título executivo judicial líquido, deste podendo de logo dispor no juízo de execução cível, levanta sério questionamento quanto à ofensa ao princípio da congruência, entendido este como decorrência do princípio do contraditório (no âmbito do processo penal - como correlação entre acusação e sentença - e, no do processo civil, como correlação entre o pedido e a sentença). ${ }^{268}$

A ofensa à congruência, de fato, mostra-se patente, visto que ao juiz penal é dado decidir sobre matéria de indenização civil (que pode envolver questões fáticas e jurídicas), sem a prévia dedução em juízo da respectiva postulação.

Tal ofensa ganha maior expressão ao se considerar que, embora seja verificada inicialmente na correlação entre pedido e sentença (matéria cível), poderá resvalar para a correlação entre acusação e sentença (análise da pretensão acusatória), pois que a economia processual objetivada no dispositivo legal permite o aproveitamento dos mesmos atos processuais para a análise tanto da matéria cível (reparação de danos) quanto da matéria penal.

265 Interessante observar que o Código de Processo penal português, em seu art. 82-A, 1, prevê a possibilidade, de se proceder a tal indenização de ofício em prol da vítima, contudo, na excepcionalidade de particulares exigências de proteção desta.

${ }^{266}$ CABRAL, Antônio do Passo. O valor mínimo da indenização cível fixado na sentença condenatória penal: notas sobre o novo art. 387, IV do CPP. Revista da EMERJ. Rio de Janeiro, v. 13, n. 49, p. 302-328, jan./mar. 2010, p. 309-311.

${ }^{267}$ Inclusive, a legislação atual sequer prevê mecanismos para tal provocação pela vítima, o que se agrava em face da falta de atribuição constitucional do Ministério Público em defender direitos individuais disponíveis, conforme preconizado pelo art. 127, da Constituição Federal.

${ }^{268}$ BADARÓ, Gustavo Henrique Righi Ivahy. Correlação entre acusação e sentença. 2. ed. São Paulo: Revista dos Tribunais, 2009, p. 28. 
Detectando as deficiências técnicas dessa inovação trazida pela Lei $\mathrm{n}$. 11.792/2008 (reparação de indenização ex officio), ABREU E SILVA chega a defender que, para sua compatibilização com o ordenamento jurídico, deve-se instituir, mesmo que de lege ferenda, o processo de adesão pela parte civil no processo penal brasileiro, ${ }^{269}$ confirmando a tendência da superação do sistema da separação em prol do sistema da adesão facultativa, o que poderá tornar-se realidade com a efetiva implantação da adesão civil, conforme preconiza o projeto de Código de Processo Penal aprovado no Senado Federal.

\subsubsection{Novas perspectivas}

4.4.2.1 Perspectivas de direito comparado

\subsection{Alemanha}

Como um dos mecanismos para viabilizar a indenização civil em prol da vítima, o Direito Processual Penal alemão prevê o procedimento de adesão (Adhäsionsverfahren), em que a vítima, por razões de economia processual, pode fazer valer sua pretensão civil dentro do próprio processo penal (§403-406, StPO).

Apesar das vantagens trazidas pela adesão, destacando-se a praticidade e a produção de provas de ofício pelo juízo penal, ${ }^{270}$ esse procedimento não tem encontrado grande aceitação na Alemanha. ${ }^{271}$

Costuma-se apontar como razão de tal insucesso alguns fatores, como a

\footnotetext{
${ }^{269}$ ABREU E SILVA, Roberto. Sentença condenatória criminal e a reparação de danos: a estratégia de atuação da vítima. Rio de Janeiro: Lumen Juris, 2010, p. 55-56.

270 “[...] el proceso por anexión posse l avantaja de que toda prueba se practica de oficio, al contrario que en el processo civil [...]". (SCHÜNEMANN, Bernd. Obras. Buenos Aires: Rubinzal-Culzoni, 2009. v. 2. (Colección autores de derecho penal), p. 496).

${ }^{271}$ Com base em estudo apontado por SCHRÖDER, CÂMARA relata que, do total das sentenças proferidas pelos Tribunais estaduais (Ladsgericht), as sentenças proferidas em processos de adesão representam a ínfima porcentagem de $0,9 \%$, ao passo que essa porcentagem nos Tribunais locais revela-se ainda menor: 0,3\%, concluindo tratar-se de um "fenômeno de rara constatação". (CÂMARA, Guilherme Costa. Programa de política criminal orientado para a vítima do crime. São Paulo: Editora Revista dos Tribunais; Coimbra: Coimbra Editora, 2008, p. 322).
} 
possibilidade de o juízo rejeitar discricionariamente o pedido, considerando-o inadequado. $^{272}$

Sobre tal ponto, SCHÜNEMANN recorda que a Lei para Melhora dos Direitos dos Ofendidos no Processo Penal, de 2004, trouxe algumas modificações, atacando a discricionariedade do juízo penal, e prevendo recurso imediato para a rejeição do pedido. $^{273}$

Contudo, persiste a dificuldade apontada por CÂMARA, a saber, o problema da falta de motivação dos advogados, "que preferem perceber honorários muito mais expressivos através da interposição de uma ação de reparação de danos perante tribunais cíveis". 274

\subsection{Itália}

Os arts. 74 a 82, e 88, do c.p.p., regulamentam a azione civile nel processo penale, que fundamenta o sistema da adesão (facultativa) no processo penal italiano. Aquele que pretenda habilitar-se como autor de tal azione civile, passando a receber a denominação de parte civile, precisa ter experimentado danos de natureza civil em decorrência da prática da infração penal. Assim, pode ser que a persona offesa dal reato, o titular do bem jurídico-penal violado, não possa constituir-se como parte civile, em virtude de não ter direito a ressarcimento por danos civis. Também é possível que a pessoa constituída como parte civile não seja o titular do bem jurídico-penal violado, o que atesta

\footnotetext{
272 “[...] los tribunales penales temen, frecuentemente, un retraso o complicación del procedimiento, y por tal motivo hacen uso, no pocas vezes, de la posibilidad jurídica de rechazar el procedimiento de adhesión por 'inadecuado’ (\$405, OPP)”. (ESER, Albin. Acerca del renacimiento de la víctima en el procedimiento penal: tendencias nacionales e internacionales. Tradução de Fabrício O. Guariglia e Fernando J. Córdoba. In: MAIER, Julio B. J. (Comp.). De los delitos y de las víctimas. Buenos Aires: Ad Hoc, 2001, p. 29).

${ }^{273} \mathrm{Na}$ íntegra: "[...] en la Ley para la mejora de los derechos de la víctima de 2004, el legislador ha fortalecido notablemente la posición del lesionado en el processo por anexión limitando las posibilidades del tribunal para desestimar la petición de anexión. Sin embargo, en el \$406 Abs. 1 cuarta línea StPO, todavia se dice que el tribunal puede abstenerse de resolver cuando la petición de ejecución no se adecue al processo penal, y en la frase $5^{a}$, se dice que la petición es especialmente no adecuada, si su examen posterior retrasara considerablemente el proceso penal, incluso también si la sentencia atendiera sólo al motivo de la pretensión o a una parte de ésta. Pero ahora el juez ya no tiene poder discrecional, y en caso de que se invoque la pretensión de imdemnización incluso se finge que hay acuerdo. Además, según el párrafo $\$ 406^{a}$ $S t P O$, se puede impugnar la recusación de la solicitude por falta de idoneidade valiéndose del recurso imediato.". (SCHÜNEMANN, Bernd. Obras. Buenos Aires: Rubinzal-Culzoni, 2009. v. 2. (Colección autores de derecho penal), p. 496).

${ }^{274}$ CÂMARA, Guilherme Costa. Programa de política criminal orientado para a vítima do crime. São Paulo: Editora Revista dos Tribunais; Coimbra: Coimbra Editora, 2008, p. 322.
} 
a independência entre tais conceitos. ${ }^{275}$

Faz-se necessário consignar que o modelo de adesão, tal qual previsto no processo penal italiano, permite a participação de pessoas físicas e jurídicas, desde que titulares de direito a ressarcimento de danos cíveis, bem como de entidades e associações na defesa de interesses metaindividuais, ${ }^{276}$ como associações de proteção ambiental, sindicatos, associações profissionais, partidos políticos e o próprio Estado. ${ }^{277}$

Tal ação, de caráter acessório em relação à ação penal exercida pelo pubblico ministero, ${ }^{278}$ apresenta finalidade ressarcitória e restituitória, introduzindo interesses de natureza civil no âmbito do processo penal, ${ }^{279}$ e tem por fundamentos a economia processual e a necessidade de evitar julgamentos díspares entre a jurisdição penal e a cível. $^{280}$

Quanto aos danos de natureza civil perseguíveis pela parte civile, cuida-se tanto de danos civis patrimoniais como de danos civis não patrimoniais. Na Itália, atrelavase tradicionalmente o dano não patrimonial ex delicto ao dano moral subjetivo, o que mereceu modificação posterior. Em 2003, a Corte Constitucional italiana entendeu como

\footnotetext{
275 "La persona offesa dal reato il più delle volte coincide con il soggetto che nella fase processuale si costituirà parte civile, ma va chiarito che tra le due figure non vi è perfetta coincidenza, vale a dire non è detto che la persona offesa dal reato sia anche legittimato a costituirsi parte civile nella fase processuale. Può accadere, infatti, che la persona offesa dal reato che, come si è detto, è titolare del bene giuridico tutelato dela norma, sia diversa dalla persona danneggiata dal reato che, in quanto tale, è titolare dell'interesse al risarcimento del danno, economicamente valutabile." (GAROFOLI, Vincenzo. Diritto processuale penale. Milão: Giuffrè, 2008, p.165-166).

${ }^{276}$ Ao discorrer sobre uma proteção mais ampla do ser humano, MEDEIROS NETO menciona que a extensão da tutela jurídica da pessoa, de uma esfera meramente patrimonial para uma esfera extrapatrimonial (moral), e a expansão da destinação de referida tutela, do campo individual para o campo coletivo ou social, representam destacado e necessário passo no processo de valorização e tutela dos direitos fundamentais, evolução que significa uma resposta às demandas da cidadania." (MEDEIROS NETO, Xisto Tiago de. Dano moral coletivo. 2. ed. LTr, 2007, p. 121).

${ }^{277}$ MANISCALCO, Marzia. L'azione civile nel processo penale. Milão: CEDAM, 2006, p. 58-72.

278 "Em suma, no direito italiano, a ação civil é inserida no processo penal, como uma relação processual acessória. As duas ações têm regras próprias no C.P.P. A ação penal é promovida pelo M.P., enquanto a ação civil somente poderá ser exercida pelo prejudicado. [...] Em consequência de seu caráter acessório, a ação civil no processo penal não pode ter prosseguimento quando o processo principal extinguir-se por qualquer circunstância típica do processo penal, incluindo-se a sentença penal absolutória, quando se reconhece qualquer das excludentes de criminalidade." (MEIRA, José de Castro. A experiência alienígena quanto ao ressarcimento do dano "ex delicto". BDJur, Brasília/DF, 01 abr. 2008. Disponível em: $<$ http://bdjur.stj.gov.br/dspace/handle/2011/16769>. Disponível em: <http://bdjur.jus.br> Acesso em: 15 set. 2010).

${ }^{279}$ Sobre a concepção de restituição e de ressarcimento no processo penal italiano, cf. MANISCALCO, Marzia. L'azione civile nel processo penale. Milão: CEDAM, 2006, p. 25-29.

280 "Le ragioni per le quali il legislatore ha permesso l'inserimento nel processo penale di un soggetto portatore di um interesse civilistico, vanno riscontrare, oltre che nel risparmio di energie processual (se il danneggiato del reato potesse agire solo in sede di giudizio civile, avremmo la duplicazione di due processi: quello penale e quello civile), anche nella necessità di evitarei l contrasto di giudicati che si potrebbe verificare tra giudizio civile e giudizio penale, sì da permettere il mantenimento di uma certa $<<$ coerenza logica $>>$ del sistema giuridico." (GAROFOLI, Vincenzo. Diritto processuale penale. Milão: Giuffrè, 2008, p. 167).
} 
compreendidos na categoria de danos não patrimoniais espécies distintas: o dano moral subjetivo, que consistiria em perturbação transitória do estado de ânimo da pessoa, o dano biológico em sentido estrito, que seria a lesão à integridade psíquica e física do individuo, e o dano existencial, que abrange outros interesses constitucionalmente assegurados. ${ }^{281}$

A constituição em parte civile somente pode ser efetuada no âmbito do processo judicial, desde a udienza preliminare até antes da ultimação da constituição das partes que precede o dibattimento (art. 79, 1, do c.p.p.), devendo o pedido conter, sob pena de inadmissibilidade: a) dados gerais sobre o requerente; b) dados gerais sobre o acusado; c) dados do defensor e indicação da procuração; d) exposição das razões que justificam a demanda; ${ }^{282}$ e) assinatura do defensor (art. 78, 1, do c.p.p.).

Por fim, cumpre registrar que a parte civile, diferentemente da persona offesa dal reato, dispõe de poder de impugnação sobre as decisões judiciais, na forma prevista no art. 576, 1, do c.p.p. ${ }^{283}$

\subsection{Portugal}

Uma vez sofrendo danos em decorrência da prática do crime, a vítima, em sua acepção de lesado, poderá apresentar um pedido de indenização civil, que seguirá em adesão ao processo penal (artigos 71 a 84, do CPPP).

O CPPP de 1987 adota o princípio da adesão (obrigatória), segundo o qual, o pedido de indenização deverá necessariamente ser formulado no âmbito do juízo penal, sendo deduzido no processo penal respectivo (art. $71^{284}$ ). A essa regra de adesão

\footnotetext{
${ }^{281}$ MANISCALCO, Marzia. L'azione civile nel processo penale. Milão: CEDAM, 2006, p. 29-30.

${ }^{282}$ Quanto à causa de pedir (razões que justificam a demanda), oportuno que seja citada a experiência italiana: o art. 78, 1, do atual Codice di Procedura Penale, dentre os requisitos da adesão, refere-se à espozione dele ragioni che giustificano la domanda, suprimindo o adjetivo sommaria, que constava no código anterior. Daí a jurisprudência, em um primeiro momento, passar a exigir uma causa petendi contendo uma exposição precisa e analítica. Todavia, a jurisprudência mais recente faz uma distinção entre prejudicado-vítima e prejudicado-não vítima. Assim, se a pessoa é, ao mesmo tempo, vítima e prejudicado, basta uma mera referência aos fatos imputados ou ao tipo penal indicado na acusação, mas se o prejudicado não foi a vítima do delito, exige-se uma exposição mais completa das razões do pedido: MANISCALCO, Marzia. L'azione civile nel processo penale. Milão: CEDAM, 2006, p. 96-98.

283 "La parte civile può proporre impugnazione, contro i capi della sentenza di condanna che riguardano l'azione civile e, ai soli effetti della responsabilità civile, contro la sentenza di proscioglimento pronunciata nel giudizio. La parte civile può altresì proporre impugnazione contro la sentenza pronunciata a norma dell'articolo 442, quando ha consentito alla abbreviazione del rito."

${ }_{284}$ "O pedido de indemnização civil fundado na prática de um crime é deduzido no processo penal respectivo, só o podendo ser em separado, perante o tribunal civil, nos casos previstos na lei."
} 
obrigatória abrem-se hipóteses excepcionais, falando-se, nesse caso, de um princípio da opção ${ }^{285}$ (art. 72, $\left.1^{286}\right)$.

Quanto ao fundamento do sistema português, refere FERNANDES que este é procurado tanto na perspectiva dos interesses da vítima - que se beneficia com a economia de tempo e dinheiro, além de aproveitar-lhe as provas produzidas pelos órgãos estatais de persecução penal - quanto na perspectiva do interesse geral, apontando as vantagens de tratar-se de um remédio para a inércia probatória do Ministério Público, de um incentivo para a descoberta da verdade, de uma garantia de maior eficácia da prevenção geral e especial e, por fim, de um instrumento para afastar os riscos de contradição entre os julgados civil e penal. ${ }^{287}$

O procedimento para o requerimento em pauta encontra-se regulado nos arts. 72 a 84, do CPPP, sendo relevante anotar que o demandante, nos termos do art. 74, 2, do CPPP, tem sua intervenção processual vinculada à sustentação e à prova do pedido de indenização civil, competindo-lhe, correspondentemente, os direitos conferidos por lei aos assistentes.

Por fim, impende registrar dois aspectos interessantes quanto ao procedimento, constantes no art. 82, 1, 2 e 3, do CPPP, ${ }^{288}$ a saber, a possibilidade de, em não se dispondo de elementos bastantes para fixar uma indenização líquida, o Tribunal condenar no que se liquidar em execução de sentença, a qual tramitará na instância cível, podendo o Tribunal, de ofício ou a requerimento, estabelecer uma indenização provisória; o aspecto supérstite a

285 FERNANDES, Fernando. O processo penal como instrumento de política criminal. Coimbra: Almedina, 2008. (Coleção teses), p. 542-543.

286 “1 - O pedido de indemnização civil pode ser deduzido em separado, perante o tribunal civil, quando: $a$ ) $\mathrm{O}$ processo penal não tiver conduzido à acusação dentro de oito meses a contar da notícia do crime, ou estiver sem andamento durante esse lapso de tempo; $b$ ) $\mathrm{O}$ processo penal tiver sido arquivado ou suspenso provisoriamente, ou o procedimento se tiver extinguido antes do julgamento; c) O procedimento depender de queixa ou de acusação particular; $d$ ) Não houver ainda danos ao tempo da acusação, estes não forem conhecidos ou não forem conhecidos em toda a sua extensão; e) A sentença penal não se tiver pronunciado sobre o pedido de indemnização civil, nos termos do n. ${ }^{\circ} 3$ do artigo 82. ${ }^{\circ}, f$ ) For deduzido contra o arguido e outras pessoas com responsabilidade meramente civil, ou somente contra estas haja sido provocada, nessa acção, a intervenção principal do arguido; $g$ ) $\mathrm{O}$ valor do pedido permitir a intervenção civil do tribunal colectivo, devendo o processo penal correr perante tribunal singular; $h$ ) O processo penal correr sob a forma sumária ou sumaríssima; i) O lesado não tiver sido informado da possibilidade de deduzir o pedido civil no processo penal ou notificado para o fazer, nos termos do $n .^{\circ} 1$ do artigo $75 .^{\circ}$ e do n. 2 do artigo $77 .^{\circ}$ "

287 FERNANDES, Fernando. O processo penal como instrumento de política criminal. Coimbra: Almedina, 2008. (Coleção teses), p. 543.

288 "1 - Se não dispuser de elementos bastantes para fixar a indemnização, o tribunal condena no que se liquidar em execução de sentença. Neste caso, a execução corre perante o tribunal civil, servindo de título executivo a sentença penal. 2 - Pode, no entanto, o tribunal, oficiosamente ou a requerimento, estabelecer uma indemnização provisória por conta da indemnização a fixar posteriormente, se dispuser de elementos bastantes, e conferir -lhe o efeito previsto no artigo seguinte. 3 - O tribunal pode, oficiosamente ou a requerimento, remeter as partes para os tribunais civis quando as questões suscitadas pelo pedido de indemnização civil inviabilizarem uma decisão rigorosa ou forem susceptíveis de gerar incidentes.” 
ser realçado consiste na possibilidade de o juízo penal remeter as partes à instância cível caso as questões suscitadas pelo pedido de indenização civil inviabilizem uma decisão rigorosa ou forem suscetíveis de gerar incidentes.

\subsection{Argentina}

A ação civil e a atuação do actor civil (autor civil) encontram-se disciplinadas nos arts. 14 a 17 , e 87 a 96 , do $C P P N .^{289}$

Para o exercício da ação civil - contra o acusado e/ou terceiros civilmente responsáveis - o titular do interesse de restituição/ressarcimento deverá constituir-se autor civil em petição fundamentada, a ser apresentada até o término da instrução.

Quanto às faculdades processuais do autor civil, conforme o art. 91, do CPPN, o referido sujeito processual terá "la intervención necesaria para acreditar la existencia del hecho delictuoso y los daños y perjuicios que le haya causado, y reclamar las medidas cautelares y restituciones, reparaciones e indemnizaciones correspondientes."

Por fim, cumpre registrar que o autor civil poderá desistir a qualquer momento, ficando responsável, porém, pelas custas decorrentes de sua intervenção, fixando o art. 94 as hipóteses de desistência tácita. ${ }^{290}$

4.4.2.2 Perspectivas do Código Projetado: a introdução do sistema de adesão

A inovadora disciplina da parte civil no Código de Processo Penal projetado já em sua redação final (arts. 81 a $84^{291}$ ) - representa a adoção efetiva, no ordenamento

289 "[...] la consideración de los interesses de la víctima en la búsqueda de la solución integral para el conflicto penal no se agota, ni mucho menos, acordándole la posibilidad de participar, en alguna medida, en el ejercicio de la pretensión represiva, sino que compreende, también, decididamente, la posibilidad de ejercer la acción civil tendiente al resarcimiento de los daños producidos por el delito dentro del procedimiento penal mismo." (CÓRDOBA, Fernando. La posición de la víctima en el nuevo código procesal penal de la nación. Buenos Aires: Del Puerto, 1993, p. 86).

290 “[...] Se lo tendrá por desistido cuando no concrete la demanda en la oportunidad fijada en el artículo 93 o no comparezca al debate o se aleje de la audiencia sin haber formulado conclusiones."

291 "Art. 81. A vítima ou, no caso de sua ausência ou morte, as pessoas legitimadas a ingressar como assistentes, sem ampliar a matéria de fato constante da denúncia, poderá, no prazo de 10 (dez) dias, requerer a recomposição civil do dano moral causado pela infração, nos termos e nos limites da imputação penal, para 
jurídico brasileiro, do sistema de adesão facultativa, tendência que já vinha sendo apontada em face das modificações legais recentes. ${ }^{292}$

De fato, o projeto referido legitima a vítima ou seus sucessores - no caso de morte ou ausência daquela - a requerer a recomposição civil do dano (art. 81, caput), que será objeto, juntamente com a pretensão penal processual, de apreciação no mesmo processo, objetivando, como mecanismo próprio do sistema de adesão, economia processual e redução da possibilidade de decisões discrepantes nas diferentes instâncias (penal e civil).

Dentro da sistemática do Código projetado, a adesão civil apresenta-se como uma das opções postas à disposição da vítima - que se mostre prejudicada em razão do delito - para a satisfação, de forma específica, de seu interesse de reparação de danos civis, persistindo as demais possibilidades, a saber, o ajuizamento de ação própria no juízo cível e o título executivo judicial, obtenível a partir da sentença penal condenatória.

Insta registrar que mencionada inovação despertou, ainda durante a tramitação do PLS n. 156/09 no Senado Federal, diversas críticas, levando a algumas proposições pela supressão de tal instituto.

o que será notificado após o oferecimento da inicial acusatória. $\S 1^{\circ} \mathrm{O}$ arbitramento do dano moral será fixado na sentença condenatória e individualizado por pessoa, no caso de ausência ou morte da vítima e de pluralidade de sucessores habilitados nos autos. $\S 2^{\circ}$ Se a vítima não puder constituir advogado, circunstância que deverá constar da notificação, ser-lhe-á nomeado um pelo juiz, ainda que apenas para o ato de adesão civil à ação penal, caso em que o advogado poderá requerer a extensão do prazo por mais 10 (dez) dias improrrogáveis. $\S 3^{\circ}$ A condenação do acusado implicará, ainda, a condenação em honorários, observadas as regras do Código de Processo Civil, devidos ao advogado constituído pela parte civil ou nomeado pelo juiz. Art. 82. A parte civil terá as mesmas faculdades e os mesmos deveres processuais do assistente, além de autonomia recursal quanto à matéria tratada na adesão, garantindo-se ao acusado o exercício da ampla defesa. Parágrafo único. Quando o arbitramento do dano moral depender da prova de fatos ou circunstâncias não contidas na peça acusatória ou a sua comprovação puder causar transtornos ao regular desenvolvimento do processo penal, a questão deverá ser remetida ao juízo cível, sem prejuízo do disposto no inciso II do art. 475-N do Código de Processo Civil.

Art. 83. A adesão de que cuida este Capítulo não impede a propositura de ação civil contra as pessoas que por lei ou contrato tenham responsabilidade civil pelos danos morais e materiais causados pela infração. Se a ação for proposta no juízo cível contra o acusado, incluindo pedido de reparação de dano moral, estará prejudicada a adesão na ação penal, sem prejuízo da execução da sentença penal condenatória, na forma do disposto no art. 84. $\S 1^{\circ}$ A reparação dos danos morais arbitrada na sentença penal condenatória deverá ser considerada no juízo cível, quando da fixação do valor total da indenização devida pelos danos causados pelo ilícito. $\S 2^{\circ}$ No caso de precedência no julgamento da ação civil contra o acusado e/ou outros responsáveis civis pelos danos decorrentes da infração, o valor arbitrado na sentença penal para a reparação do dano moral não poderá exceder àquele fixado no juízo cível para tal finalidade. $\S 3^{\circ} \mathrm{A}$ decisão judicial que, no curso do inquérito policial ou do processo penal, reconhecer a extinção da punibilidade ou a absolvição por atipicidade ou por ausência de provas, não impedirá a propositura de ação civil.

Art. 84. Transitada em julgado a sentença penal condenatória, e sem prejuízo da propositura da ação de indenização, poderão promover-lhe a execução, no cível (art. 475-N, II, do Código de Processo Civil), as pessoas mencionadas no art. 77. Parágrafo único. O juiz civil poderá suspender o curso do processo até o julgamento final da ação penal já instaurada, nos termos e nos limites da legislação processual civil pertinente."

${ }^{292}$ ABREU E SILVA, Roberto. Sentença condenatória criminal e a reparação de danos: a estratégia de atuação da vítima. Rio de Janeiro: Lumen Juris, 2010, p. 55-56. 
Assim, em fevereiro de 2010, o Instituto dos Advogados Brasileiros (IAB), por sua Comissão Permanente de Direito Penal, enviou um parecer, ${ }^{293}$ em que sugeriu aperfeiçoamentos ao projeto. No que se refere à adesão, o IAB pugnava pela supressão total dos dispositivos relativos à parte civil, pois se trataria de matéria estranha ao juízo penal. Argumentava o IAB que não se poderia compatibilizar a parte civil, com suas discussões de natureza pecuniária, com as finalidades do processo penal, das quais se destacaria a implementação de franquias fundamentais fixadas pelo Constituinte em favor do indivíduo.

Em maio de 2010, a Associação dos Juízes Federais do Brasil (AJUFE) apresentou sua nota técnica n. 03/2010, ${ }^{294}$ sugerindo uma total reformulação da seção referente à intervenção civil, que passaria a intitular-se Da Responsabilidade Civil. Asseverava que a adesão causaria confusão e prejuízo ao trâmite do processo penal, com poucos ganhos significativos, o que justificaria a manutenção do sistema atualmente vigente (Código de Processo Penal, arts. 63 a 68 e 387, inciso IV), retomando-se a controvertida fixação ex officio de um valor mínimo para reparação de danos, não só morais, mas também patrimoniais, no que se possibilitaria ao interessando a busca por valores indenizatórios de maior monta no juízo cível.

O Conselho Nacional de Justiça (CNJ), por sua vez, editou, em agosto de 2010, sua Nota Técnica n. 10/2010, ${ }^{295}$ em que se limitou a manifestar sua preocupação quanto à intervenção de parte civil no processo criminal, o que, nos termos constantes no projeto, poderia causar "uma excessiva dilação do processo, comprometendo a razoável duração da ação penal, além de gerar uma contaminação de interesses civis no processo penal", recomendando, ao final, uma revisão dos dispositivos projetados.

Cumpre assinalar, entretanto, que essas modificações sugeridas não restaram acatadas pelo Senado Federal, prevalecendo o texto constante no Substitutivo (Emenda n. 2 - CCJ), aprovado em sua Comissão de Constituição e Justiça, em 17 de março de 2010, e no plenário da referida Casa, em 09 de novembro de 2010.

Tornando ao texto aprovado pelo Senado Federal, pode-se afirmar que, diferentemente de outras legislações, a adesão prevista no Código projetado não possibilita

\footnotetext{
${ }^{293}$ Disponível em: <http://www.iabnacional.org.br/IMG/pdf/doc-2377.pdf〉. Acesso em: 15 jan. 2010.

${ }^{294}$ Disponível em: <http://ebookbrowse.com/nota-tecnica-pls-156-2008-novo-cpp-pdf-d120931697>. Acesso em 22.12.2011.

${ }^{295}$ Disponível em: <http://www.cnj.jus.br/atos-administrativos/atos-da-presidencia/317-notas-tecnicas/11221nota-tecnica-no-102010a >. Acesso em 15.01.2010.
} 
a inclusão no processo do responsável civil, ${ }^{296}$ de modo que a vítima deverá valer-se, se quiser exercer a pretensão indenizatória em relação àquele, de ação própria no juízo cível (art. 83).

Um dado extremamente relevante precisa ser desde já referido: a adesão civil prevista nos arts. 81 a 84, do Código projetado, é restrita à satisfação de danos morais, excluindo-se os danos patrimoniais. Para os autores do Projeto, essa opção se mostraria mais adequada "para o fim de se preservar a celeridade da instrução criminal, impedindo o emperramento do processo, inevitável a partir de possíveis demandas probatórias de natureza civil". 297

Essa restrição à exclusiva satisfação de danos morais, somada à exclusão do responsável civil, leva a uma melhor interpretação do art. 83 projetado. Assim, à vítima faculta-se simultaneamente a propositura da adesão civil no processo penal por danos morais (contra o acusado) e a propositura de ação própria no juízo cível, por danos morais e/ou materiais, contra o responsável civil.

Faculta-se-lhe também, dentro desse quadro, a possibilidade de a vítima, na referida ação perante o juízo cível (contra o responsável civil), também incluir o acusado no polo passivo, desde que o pedido quanto a esse, em tal ação, se limite a danos materiais, pois que o pleito por danos morais, por óbvio, prejudicaria a adesão civil (art. 83, caput, $2^{\mathrm{a}}$ parte).

Em tal contexto, os $\S \S 1^{\circ}$ e $2^{\circ}$ do art. 83 objetivam, de algum modo, compatibilizar as sentenças penal e cível, no que se refere à fixação de reparação de danos. Assim, havendo precedência da sentença penal em relação à sentença cível, o juízo cível deverá levar em consideração a fixação do dano moral contra o acusado pelo juízo penal para, por sua vez, fixar o valor total da indenização contra o responsável civil; na situação contrária, ou seja, havendo precedência da sentença cível em relação à sentença penal, o juízo penal, ao cominar o valor de reparação do dano moral contra o acusado, não poderá exceder o quantum fixado na sentença cível para reparação de danos morais contra o responsável civil.

Esse tratamento diferenciado entre as sentenças cível e penal, com prestígio da primeira (afinal, a sentença cível pode vincular a fixação do dano moral da sentença penal,

\footnotetext{
${ }^{296}$ Como é o caso, por exemplo, da Argentina. Cf. art. 97 ss. do CPP de la Nación: ARGENTINA. Código Procesal Penal de la Nación. Disponível em: <http://www.infoleg.gov.ar/infolegInternet/anexos/04999/383/texact.htm>. Acesso em: 05 out. 2010.

${ }^{297}$ BRASIL. Congresso. Senado. Projeto de Lei do Senado n. ${ }^{\mathbf{0}}$ 156/2009: redação final. Disponível em: <http://www.senado.gov.br/atividade/materia/getPDF.asp?t=85509\&tp=1>. Acesso em: 15 mar. 2011.
} 
ao menos quanto a seu patamar máximo, o que não ocorre na situação inversa), explica-se pelo fato de ser o juízo cível o juízo natural para a discussão da matéria responsabilidade civil e não o juízo penal.

A questão da reparação de danos de ofício, trazida pela Lei n. 11.719/2008, encontra-se superada no Código projetado, conforme se pode interpretar do inciso IV, do art. 423, o qual dispõe que o juiz, quando da sentença condenatória, "arbitrará o valor da condenação civil pelo dano moral, se for o caso". Ou seja, dada a novel faculdade dispensada à própria vítima para promoção da adesão civil a fim de obter a recomposição de danos morais, dispensa-se o juiz de dispor sobre tal matéria de ofício, evitando-se os problemas daí decorrentes.

Considera-se a parte civil tecnicamente como parte, na medida em que essa formula uma postulação de natureza cível no processo penal em paralelo à pretensão processual (penal) formulada pelo Estado. Assim, suas faculdades processuais, desde que voltadas ao interesse de reparação de danos morais, devem ser tidas como próprias da parte autora, sob pena de cerceamento do princípio do contraditório.

Em caso de adesão civil ao processo penal, dada a participação processual da vítima como parte civil, eventual sentença absolutória lhe afetará juridicamente. O não exercício de tal faculdade, porém, pela vítima, impedirá a produção de efeitos jurídicos contra si.

Se, por um lado, o instituto da adesão tem suas benesses, por outro, pode acarretar um retardo na marcha do procedimento penal, até mesmo porque seu objeto traz matéria estranha ao juízo penal, a qual, pode se revestir de considerável complexidade. Assim, o parágrafo único do art. 79, na hipótese em que "a comprovação do dano moral puder causar transtornos ao regular desenvolvimento do processo penal", permite que o juízo penal remeta a questão referente à adesão ao juízo cível. ${ }^{298}$

Merece igualmente atenção o caráter acessório da adesão civil. De fato, não obstante ã inexistência de regra expressa em tal sentido, a extinção do processo quanto à pretensão processual (penal), por qualquer motivo, não permite a subsistência da pretensão civil nos autos. Não se deve olvidar que se trata a reparação de danos de matéria originariamente alheia ao juízo penal, somente se sujeitando a este em razão das vantagens do sistema da adesão. Desaparecida a pretensão penal, tais vantagens não mais subsistem,

${ }^{298}$ A outra hipótese em que tal dispositivo permite aludida remessa se dá quando "o arbitramento do dano moral depender da prova de fatos ou circunstâncias não contidas na peça acusatória”. Cf. BRASIL. Congresso. Senado. Projeto de Lei do Senado n. ${ }^{0}$ 156/2009: redação final. Disponível em: <http://www.senado.gov.br/atividade/ma teria/getPDF.asp?t=85509\&tp=1>. Acesso em: 15 mar. 2011. 
devendo a matéria cível ser analisada no juízo a princípio competente (juízo cível).

Diversas questões outras podem ser trazidas à baila que não encontram expressa resposta no Código projetado e que certamente desafiarão a literatura jurídica e a jurisprudência em face da novidade que o sistema de adesão representa no ordenamento jurídico nacional. Como exemplo, no que se refere à revelia do acusado quanto ao pedido da parte civil, pode-se perguntar se haverá ou não de surtir o efeito da confissão ficta.

Em tese, por se tratar de interesse disponível, recomendar-se-ia o reconhecimento de tal efeito, seguindo-se as regras do processo civil.

Todavia, tal solução poderia implicar prejuízo à finalidade da adesão consistente em evitar julgamentos díspares, pois o prosseguimento do trâmite do processo penal poderia resultar na absolvição do acusado, por exemplo, por estar provada a inexistência do fato.

Assim, do mesmo processo resultariam julgamentos contraditórios entre si, de modo que se faz salutar impedir a confissão ficta em face de possível revelia do acusado quanto ao pedido formulado pela parte civil.

4.4.2.3 Algumas considerações críticas sobre o objeto da adesão civil prevista no Código projetado

4.4.2.3.1 A ampliação do objeto da pretensão na adesão civil: danos patrimoniais e demais danos não patrimoniais

Ao se prever a adesão civil, permite-se a dedução de uma pretensão civil no âmbito do processo penal, a saber, a exigência do sujeito prejudicado em prevalecer seu interesse de reparação de danos sobre o interesse do acusado. ${ }^{299}$

Embora o projeto tenha utilizado acertadamente a expressão recomposição civil - que compreende tanto a hipótese de restituição do status quo ante em benefício do prejudicado quanto, em face da impossibilidade de tal restituição, a reparação por todos os danos perpetrados -, reduziu o objeto da pretensão dedutível na adesão à perseguição dos

\footnotetext{
${ }^{299}$ Aqui sim, o tradicional conceito civilístico de pretensão pode ser utilizado fielmente.
} 
danos morais decorrentes da infração penal.

Nesse ponto, questiona-se a possibilidade de ampliação do objeto da pretensão civil, veiculada na adesão, de modo a estender-se a outros tipos de danos. Essa ampliação poderia atender melhor aos interesses da vítima. Dessa forma, bem poderia o objeto da pretensão civil incluir, além dos danos morais já previstos, os danos patrimoniais e a toda a sorte dos demais danos não patrimoniais, dos quais o dano moral constitui apenas uma espécie. $^{300}$

Faz-se mister ressaltar que, com a devida vênia, em discordância com o entendimento da comissão de juristas redatora do projeto, ${ }^{301}$ não se vislumbra ser a opção pelos danos morais a mais adequada para evitar o retardamento da instrução criminal. ${ }^{302}$

$\mathrm{Na}$ verdade, uma maior ou menor complexidade não está necessariamente vinculada à natureza do dano, mas às peculiaridades do caso concreto, não se justificando, assim, a exclusão a priori nem de danos patrimoniais nem de danos não patrimoniais do âmbito da adesão civil, nem tampouco a vedação à cumulação de danos de natureza diversa. O que importa, evidentemente, é que o tema discutido, não cause comprometimento ao regular trâmite do procedimento penal.

Essa ampliação é admitida no Direito italiano, por exemplo. Conforme visto anteriormente (4.4.2.1.2), o instituto da parte civile permite a persecução tanto de danos civis patrimoniais como de danos civis não patrimoniais. Como também referido, a Corte Constitucional italiana entendeu como compreendidas na categoria de danos não patrimoniais espécies distintas: o dano moral subjetivo, que consistiria em perturbação transitória do estado de ânimo da pessoa, o dano biológico em sentido estrito, que seria a lesão à integridade psíquica e física do indivíduo, e o dano existencial, que abrange outros

\footnotetext{
300 "Em que pese o uso em larga escala da expressão 'dano moral', tem ela recebido críticas, considerando-se que a sua noção, desde a concepção, ligar-se-ia à esfera da dor e do sofrimento, aspectos puramente subjetivos, referidos ao campo dos sentimentos. Daí por que não se adequaria tal termo à compreensão do dano impingido a interesses que, mesmo não refletindo interesse patrimonial e igualmente postando-se alheios à esfera do sentir, estão inegavelmente enquadrados como direitos inerentes à projeção de valores e bens ínsitos à dignidade humana, em sua ampla visualização, a exemplo do que representa o direito ao respeito ao nome, à consideração e reputação social, o direito do autor e o direito à imagem.”. (MEDEIROS NETO, Xisto Tiago de. Dano moral coletivo. 2. ed. LTr, 2007, p. 50).

${ }^{301}$ Para a Comissão de juristas, "a opção pelos danos morais se apresentou como a mais adequada, para o fim de se preservar a celeridade da instrução criminal, impedindo o emperramento do processo, inevitável a partir de possíveis demandas probatórias de natureza civil." (Cf. BRASIL. Congresso. Senado. Projeto de Lei do Senado no 156/2009: texto inicial. Disponível em: <http://legis.senado.gov.br/mate-pdf/58503.pdf〉. Acesso em: 21 out. 2010).

${ }^{302} \mathrm{Na}$ situação concreta, pode mesmo ocorrer de a análise de um dano patrimonial mostrar-se bem menos complexa. Assim, o dano patrimonial decorrente de um acidente automobilístico pode ser mais facilmente verificável que o sofrimento causado a alguém ou mesmo do que o estrago causado por uma infração à imagem da vítima.
} 
interesses constitucionalmente assegurados. ${ }^{303}$

\subsection{A ampliação do objeto da pretensão na adesão civil: danos metaindividuais}

Outro questionamento que se pode fazer quanto ao objeto da pretensão dedutível na adesão civil consiste em indagar se seria possível o acréscimo à tutela da reparação de danos de âmbito meramente individual, tal qual prevista no Código projetado, de uma tutela de reparação de danos, patrimoniais ou não, de âmbito metaindividual, em atenção às atuais demandas da cidadania. ${ }^{304}$

Tome-se, por exemplo, um processo penal em que o Ministério Público ofereça denúncia em face de crime de poluição de um rio ou de seus afluentes que enseje a necessidade de interrupção do abastecimento público de água de uma comunidade (Lei n. 9.605/98, art. 54, §2 $2^{\circ}$ III). Contra o(s) denunciado(s), poderiam ser deduzidos, em tese, pedidos de recomposição civil de danos, patrimoniais ou não, cujos interesses sejam difusos (poluição do rio e de seus afluentes e suas repercussões no ecossistema), coletivos

\footnotetext{
${ }^{303}$ MANISCALCO, Marzia. L'azione civile nel processo penale. Milão: CEDAM, 2006, p. 29-30.

304 Ao discorrer sobre uma proteção mais ampla do ser humano, MEDEIROS NETO menciona que a extensão da tutela jurídica da pessoa, de uma esfera meramente patrimonial para uma esfera extrapatrimonial (moral), e a expansão da destinação de referida tutela, do campo individual para o campo coletivo ou social, representam destacado e necessário passo no processo de valorização e tutela dos direitos fundamentais, evolução que significa uma resposta às demandas da cidadania”. (MEDEIROS NETO, Xisto Tiago de. Dano moral coletivo. $2^{\mathrm{a}}$ ed. LTr, 2007. p. 121). Interessante registrar que o dano moral coletivo, expressão sinônima de dano moral metaindividual, já encontra previsão na jurisprudência do STJ: "ADMINISTRATIVO - TRANSPORTE - PASSE LIVRE - IDOSOS - DANO MORAL COLETIVO DESNECESSIDADE DE COMPROVAÇÃO DA DOR E DE SOFRIMENTO - APLICAÇÃO EXCLUSIVA AO DANO MORAL INDIVIDUAL - CADASTRAMENTO DE IDOSOS PARA USUFRUTO DE DIREITO - ILEGALIDADE DA EXIGÊNCIA PELA EMPRESA DE TRANSPORTE ART. 39, § $1^{\circ}$ DO ESTATUTO DO IDOSO - LEI 10741/2003 VIAÇÃO NÃO PREQUESTIONADO. 1. O dano moral coletivo, assim entendido o que é transindividual e atinge uma classe específica ou não de pessoas, é passível de comprovação pela presença de prejuízo à imagem e à moral coletiva dos indivíduos enquanto síntese das individualidades percebidas como segmento, derivado de uma mesma relação jurídicabase. 2. O dano extrapatrimonial coletivo prescinde da comprovação de dor, de sofrimento e de abalo psicológico, suscetíveis de apreciação na esfera do indivíduo, mas inaplicável aos interesses difusos e coletivos. 3. Na espécie, o dano coletivo apontado foi a submissão dos idosos a procedimento de cadastramento para o gozo do benefício do passe livre, cujo deslocamento foi custeado pelos interessados, quando o Estatuto do Idoso, art. 39, $\S 1^{\circ}$ exige apenas a apresentação de documento de identidade. 4. Conduta da empresa de viação injurídica se considerado o sistema normativo. 5. Afastada a sanção pecuniária pelo Tribunal que considerou as circunstâncias fáticas e probatória e restando sem prequestionamento o Estatuto do Idoso, mantém-se a decisão. 5. Recurso especial parcialmente provido." (STJ - 2 ${ }^{\mathrm{a}}$ T., - rel. Min. Eliana Calmon - REsp 1057274/RS - j.01.12.2009 - DJe 26/02/2010): BRASIL. Superior Tribunal de Justiça. Recurso Especial no 1.057.274, do Tribunal de Justiça do Rio Grande do Sul. Brasília, DF, 1 de dezembro de 2009. Disponível em: <http://www.stj.jus.br/SCON/jurisprudencia/doc.jsp? li vre $=$ REsp $+1057274 \& \& b=A C O R \& p=$ true $\& \mathrm{t}=\& \mathrm{l}=10 \& \mathrm{i}=1>$. Acesso em: 26 out. 2010.
} 
(dano ambiental de repercussão relativa à comunidade diretamente afetada) e ainda individuais homogêneos (prejuízos eventuais em razão do corte no abastecimento d'água).

Em face da existência de prejudicados difusos ou coletivos, deveria a lei proteger também seus interesses como o faz em relação a interesses individuais. Assim, entes estatais, órgãos públicos ou mesmo associações privadas que tenham, dentre suas finalidades, a defesa do interesse metaindividual afetado poderiam pleitear a recomposição civil de danos, patrimoniais ou não, sob legitimação extraordinária, sem prejuízo de fazê-lo o próprio Ministério Público, em defesa dos interesses sociais (CF, art. 127), como verdadeiro defensor societatis, ${ }^{305}$ de modo que quando do oferecimento da denúncia, o membro do Parquet poderia deduzir igualmente ambas as pretensões, a processual penal e a reparatória metaindividual (civil). ${ }^{306}$

Essa possibilidade de defesa de interesses civis metaindividuais por entidades, em sede de adesão civil, parece-nos, a princípio, cabível, ${ }^{307}$ visto sua grande sintonia com as demandas vitimológicas, devendo-se considerar, todavia, que caso a dedução da pretensão à reparação de danos metaindividuais viesse a ensejar transtorno ao regular trâmite do procedimento penal, o juiz penal poderia determinar a remessa da adesão ao juízo cível, fazendo uso da faculdade prevista no parágrafo único do art. 82 do Projeto, ${ }^{308}$ assegurando-se, assim, a preservação da celeridade no processo penal.

Outro aspecto ainda merece registro, a saber, a necessidade de se limitar o número de participantes na dedução da adesão civil, em se tratando de interesses metaindividuais. Tal medida mostra-se bastante salutar, pois evita o tumulto processual e mesmo o desequilíbrio de forças entre os sujeitos processuais, o que pode ser provocado pela existência de uma pluralidade de partes civis.

Dessa forma, sugere-se que, em se tratando de crimes de vítimas difusas, não se podendo determinar, portanto, vítimas específicas, a Lei permitisse a habilitação de uma única entidade (pública ou privada) para atuar em defesa dos interesses jurídico-penais difusos violados, fazendo-se imprescindível a estipulação legal das hipóteses em que tal

\footnotetext{
${ }^{305}$ MOREIRA, Jairo Cruz. A intervenção do ministério público no processo civil à luz da constituição. Belo Horizonte: Del Rey, 2009, p. 40-43.

${ }^{306}$ Interessante observar que existe uma relação de maior compatibilidade entre a pretensão acusatória, de cunho público, e a pretensão reparatória, de cunho metaindividual, se comparada com a relação existente entre a pretensão acusatória pública e uma pretensão reparatória meramente individual.

${ }^{307}$ Cf. RODRIGUES, Roger de Melo. Adesão civil e "dano moral coletivo" no projeto do novo CPP. In: Boletim IBCCRIM. São Paulo: IBCCRIM, ano 18, n. 216, p.16-17, nov., 2010.

308 "Parágrafo único. Quando o arbitramento do dano moral depender da prova de fatos ou circunstâncias não contidas na peça acusatória ou a sua comprovação puder causar transtornos ao regular desenvolvimento do processo penal, a questão deverá ser remetida ao juízo cível, sem prejuízo do disposto no inciso II do art. 475-N do Código de Processo Civil.”
} 
habilitação se fizesse possível, bem como os requisitos para a habilitação da entidade, podendo servir como inspiração os requisitos estabelecidos no processo penal italiano (art. 91, do c.p.p.): a ausência de finalidade de lucro, a constituição legal prévia à prática da infração penal e a pertinência entre as finalidades da associação e a defesa do interesse jurídico-penal violado. ${ }^{309}$

\subsection{A PARTICIPAÇÃO DA VÍTIMA NA PRODUÇÃO DE ELEMENTOS PROBATÓRIOS}

\subsubsection{Noções gerais sobre prova}

A participação da vítima poderá ainda verificar-se diretamente na produção de elementos probatórios - considerada em si mesma - no âmbito do processo, elementos esses destinados à formação do convencimento dos sujeitos processuais.

Cumpre ressaltar que a participação ora referida tem total independência em relação às demais modalidades de participação (condicionamento à manifestação da vítima, controle sobre a acusação pública, assistência e adesão civil). Assim, por exemplo, ainda que a vítima não se habilite como assistente ou parte civil, poderá participar diretamente na produção de elementos probatórios.

A peculiaridade da modalidade de participação sob exame - que a diferencia das demais modalidades concernentes a esse direito assegurado à vítima - pode ser apontada no fato de a referida participação e a vontade da vítima em participar, consistirem, por si, em elementos integrantes do próprio modelo (tipo) processual destinado à produção de elementos probatórios, conforme se verá adiante.

Antes, porém, para melhor compreensão do tema, faz-se necessária uma abordagem acerca das noções gerais ligadas à ideia de prova.

\footnotetext{
309 Art. 91, do c.p.p.: "Gli enti e le associazioni senza scopo di lucro ai quali, anteriormente alla commissione del fatto per cui si procede, sono state riconosciute, in forza di legge, finalità di tutela degli interessi lesi dal reato, possono esercitare, in ogni stato e grado del procedimento, $i$ diritti e le facoltà attribuiti alla persona offesa dal reato."
} 
Para GOMES FILHO, ${ }^{310}$ a palavra prova tem a mesma origem etimológica do termo probo, do latim probatio e probus, que se traduz nas ideias de aprovação, confiança e correção, podendo-se distinguir-lhe, em geral, três acepções: a) a acepção de demonstração, "quando se diz que ela serve para estabelecer a verdade sobre determinados fatos"; b) a acepção de experimentação, quando indica "uma atividade ou procedimento destinado a verificar a correção de uma hipótese ou afirmação. Em outras palavras, trata-se de realizar um teste, ao fim do qual é possível admitir como verdadeira, fundada, provável etc., a proposição inicial; c) acepção de desafio, "indicando um obstáculo que deve ser superado como condição para se obter o reconhecimento de certas qualidades ou aptidões."

No que concerne em especial ao âmbito jurídico, destacam-se expressões diversas, que merecem aqui exame: a) elemento de prova: trata-se dos "dados objetivos que confirmam ou negam uma asserção a respeito de um fato que interessa à decisão da causa", ${ }^{311}$ citando-se como exemplos a declaração de uma testemunha ou o conteúdo de um documento; b) resultado de prova: que consiste na "própria conclusão que se extrai dos diversos elementos de prova existentes, a propósito de um determinado fato", 312 sendo “obtido não apenas pela soma daqueles elementos, mas, sobretudo por meio de um procedimento intelectual feito pelo juiz, que permite estabelecer se a afirmação ou negação do fato é verdadeira ou não"; 313 c) meios de prova: "referem-se a uma atividade endoprocessual que se desenvolve perante o juiz, com o conhecimento e participação das partes, visando à introdução e a fixação de dados probatórios no processo"; 314 d) meios de pesquisa, de investigação ou de obtenção de prova: "dizem respeito a certos procedimentos (em geral, extraprocessuais) regulados pela lei, com o objetivo de conseguir provas materiais, e que podem ser realizados por outros funcionários (policiais,

\footnotetext{
${ }^{310}$ GOMES FILHO, Antônio Magalhães. Notas sobre a terminologia da prova (reflexos no processo penal brasileiro). In: YARSHELL, Flávio Luiz; MORAES, Maurício Zanoide de (Coord.). Estudos em homenagem à professora Ada Pellegrini Grinover. São Paulo: DPJ Editora, 2005, p. 303-318, p. 305.

${ }^{311}$ GOMES FILHO, Antônio Magalhães. Notas sobre a terminologia da prova (reflexos no processo penal brasileiro). In: YARSHELL, Flávio Luiz; MORAES, Maurício Zanoide de (Coord.). Estudos em homenagem à professora Ada Pellegrini Grinover. São Paulo: DPJ Editora, 2005. p. 303-318, p. 307.

312 GOMES FILHO, Antônio Magalhães. Notas sobre a terminologia da prova (reflexos no processo penal brasileiro). In: YARSHELL, Flávio Luiz; MORAES, Maurício Zanoide de (Coord.). Estudos em homenagem à professora Ada Pellegrini Grinover. São Paulo: DPJ Editora, 2005. p. 303-318, p. 308.

313 GOMES FILHO, Antônio Magalhães. Notas sobre a terminologia da prova (reflexos no processo penal brasileiro). In: YARSHELL, Flávio Luiz; MORAES, Maurício Zanoide de (Coord.). Estudos em homenagem à professora Ada Pellegrini Grinover. São Paulo: DPJ Editora, 2005. p. 303-318, p. 308.

${ }^{314}$ GOMES FILHO, Antônio Magalhães. Notas sobre a terminologia da prova (reflexos no processo penal brasileiro). In: YARSHELL, Flávio Luiz; MORAES, Maurício Zanoide de (Coord.). Estudos em homenagem à professora Ada Pellegrini Grinover. São Paulo: DPJ Editora, 2005. p. 303-318, p. 309.
} 
por exemplo)"; $315-316$; e) objeto de prova: embora para a maioria dos estudiosos consista nos fatos cuja veracidade pretende se demonstrar, ${ }^{317}$ para alguns, como GOMES FILHO, "não são os fatos que são objeto de prova, mas as afirmações sobre os fatos". 318

Quanto à expressão fonte de prova, trata-se, para GOMES FILHO, das "pessoas ou coisas das quais pode-se conseguir a prova (rectius, o elemento de prova), resultando disso a sua usual classificação em fontes pessoais (testemunhas, vítima, acusado, peritos) e fontes reais (documentos, em sentido amplo)". ${ }^{319}$ Assim, a vítima pode ser fonte de prova, por exemplo, ao prestar suas declarações em juízo e ao submeter-se a uma perícia.

Aqui, mostra-se de grande serventia a distinção registrada por RANGEL entre prova pessoal e prova real, ao classificar a prova quanto ao seu sujeito: a) prova pessoal: "é toda afirmativa consciente destinada a mostrar a veracidade dos fatos afirmados. Assim, a testemunha que narra os fatos a que assistiu e o laudo cadavérico assinado por dois peritos oficiais são exemplos de provas pessoais, pois a afirmativa emana da pessoa"; ${ }^{320} \mathrm{~b}$ ) prova real: “é a prova encontrada na 'res', não necessariamente no objeto material do crime, mas sim, em qualquer coisa que tenha vestígios do crime. Assim, o ferimento da

${ }^{315}$ GOMES FILHO, Antônio Magalhães. Notas sobre a terminologia da prova (reflexos no processo penal brasileiro). In: YARSHELL, Flávio Luiz; MORAES, Maurício Zanoide de (Coord.). Estudos em homenagem à professora Ada Pellegrini Grinover. São Paulo: DPJ Editora, 2005. p. 303-318, p. 309.

${ }^{316}$ Sobre a distinção entre meios de prova e meios de pesquisa ou de investigação (ou de obtenção) de prova: "Com base nisso, o Código de Processo Penal italiano de 1988 disciplinou, em títulos diferentes, os mezzi di prova (testemunhos, perícias, documentos), que se caracterizam por oferecer ao juiz resultados probatórios diretamente utilizáveis na decisão, e os mezzi di ricerca della prova (inspeções, buscas e apreensões, interceptações de conversas telefônicas etc.) que não são por si fontes de conhecimento, mas servem para adquirir coisas materiais, traços ou declarações dotadas de força probatória, e que também podem ter por destinatários a polícia judiciária ou o Ministério Público". (GOMES FILHO, Antônio Magalhães. Notas sobre a terminologia da prova (reflexos no processo penal brasileiro). In: YARSHELL, Flávio Luiz; MORAES, Maurício Zanoide de (Coord.). Estudos em homenagem à professora Ada Pellegrini Grinover. São Paulo: DPJ Editora, 2005. p. 303-318, p. 309). A respeito, também conferir cf. TONINI. Paolo. A prova no processo penal italiano. Trad. Alexandra Martins e Daniela Mróz. São Paulo: RT, 2002, p. 242-243.

317 Nessa linha posicionam-se NUCCI, MIRABETE, MARQUES, TOURINHO FILHO e outros. (DEZEM, Guilherme Madeira. Da prova penal: tipo processual, provas típicas e atípicas. Campinas: Millenium, 2008, p. 86). No direito espanhol: "En nuestra opinión, y de conformidad con una corriente doctrinal cada dia más extendida, el objeto de la prueba no lo constituyen los hechos de la realidade sino las afirmaciones que las partes realizan en torno a dichos hechos". (ESTRAMPES, Manuel Miranda. La 'mínima actividad probatoria' en el proceso penal. Barcelona: JMB, 1997, p. 33).

${ }_{318}$ DEZEM, Guilherme Madeira. Da prova penal: tipo processual, provas típicas e atípicas. Campinas: Millenium, 2008, p. 86. As colocações de DEZEM baseiam-se na doutrina de GOMES FILHO: cf. GOMES FILHO, Antônio Magalhães. Notas sobre a terminologia da prova (reflexos no processo penal brasileiro). In: YARSHELL, Flávio Luiz; MORAES, Maurício Zanoide de (Coord.). Estudos em homenagem à professora Ada Pellegrini Grinover. São Paulo: DPJ Editora, 2005. p. 303-318, p. 316-318.

${ }_{319}$ GOMES FILHO, Antônio Magalhães. Notas sobre a terminologia da prova (reflexos no processo penal brasileiro). In: YARSHELL, Flávio Luiz; MORAES, Maurício Zanoide de (Coord.). Estudos em homenagem à professora Ada Pellegrini Grinover. São Paulo: DPJ Editora, 2005. p. 303-318, p.308.

${ }^{320}$ RANGEL, Paulo. Direito processual penal. 8. ed. rev. ampl. atualiz. Rio de Janeiro: Lumen Juris, 2004, p. 409 . 
vítima; o arrombamento da fechadura no furto; a roupa ensanguentada da vítima [...] são exemplos de prova real", 321

Dessarte, as declarações prestadas pela vítima em juízo constituem prova pessoal (elemento de prova pessoal) ao passo que um ferimento detectado na vítima pericialmente constitui prova real (elemento de prova real).

Não se pode olvidar também a diferenciação entre provas típicas e atípicas, concernente aos meios de prova, ou seja, ao meio ou instrumento pelo qual os elementos de prova são introduzidos no processo.

Para BADARÓ, “há consenso de que também não vigora no campo penal um sistema rígido de taxatividade dos meios de prova, sendo admitida a produção de provas não disciplinadas em lei, desde que obedecidas determinadas restrições", 322

Assim, o processo penal brasileiro admite, em face de uma liberdade probatória, meios típicos e atípicos de produção de prova, ou seja, meios de prova disciplinados ou não em Lei, podendo ser citados como meios de prova típicos a prova testemunhal, a confissão, a prova pericial, a prova documental etc.

A admissibilidade de meios de prova atípicos não permite, contudo, a fungibilidade dos meios de prova. Assim, não se pode, com o fito de introduzir determinado elemento de prova no processo, utilizar-se de regras de produção probatória inerentes a outro meio de prova, o que significaria uma prova anômala. Sobre tal conceito, na literatura jurídica italiana, LARONGA parte da proibição de fungibilidade das formas dos meios de prova (divieto di fungibilità delle forme dei mezzi di prova), para afirmar: " $E$ stato infati osservato che la prova 'atipica' non va confusa con la prova 'anomala' e cioè 'la prova 'tipica' utilizzata a fini non solo diversi da quelli che le sono propri, mas altresi carcatteristici di altra prova 'tipica"," (Cavini 1997, 837)."323

Sobre referida definição de LARONGA acerca da prova anômala, DEZEM registra as notas características do conceito: "há meio de prova expressamente previsto para a colheita da prova. No entanto, passa-se ao largo desse meio de prova típico, valendo-se de outro meio de prova". ${ }^{324}$

\footnotetext{
${ }^{321}$ RANGEL, Paulo. Direito processual penal. 8. ed. rev. ampl. atualiz. Rio de Janeiro: Lumen Juris, 2004, p. 409.

${ }^{322}$ BADARÓ, Gustavo Henrique Righi Ivahy. Provas atípicas e provas anômalas: inadmissibilidade da substituição da prova testemunhal pela juntada de declarações escritas de quem poderia ser testemunha. In: YARSHELL, Flávio Luiz; MORAES, Maurício Zanoide de (Coord.). Estudos em homenagem à professora Ada Pellegrini Grinover. São Paulo: DPJ Editora, 2005, p. 341-352, p. 344.

${ }^{323}$ LARONGA, Antonio. Le prove atipiche nel processo penale. Padova: CEDAM, 2009, p. 9.

${ }^{324}$ DEZEM, Guilherme Madeira. Da prova penal: tipo processual, provas típicas e atípicas. Campinas: Millenium, 2008, p. 152.
} 
Um exemplo de prova anômala pode ser apontado ao se pretender a juntada, aos autos, de documento contendo declaração por escrito de testemunha, em vez de proceder-se à oitiva desta em juízo. ${ }^{325}$

Sob a ótica de DEZEM, “a prova atípica, dado o princípio da liberdade probatória, é admitida no processo penal; já a prova anômala consiste em grave deformação do sistema, e não pode ser aceita. A anomalia da prova acaba por redundar em nulidade, a atipicidade não". 326

Outro conceito afim que pode ser citado é o de prova irritual, em que se vale de um meio de prova típico, mas em confronto com o tipo (modelo) previsto em Lei. ${ }^{327}$

Acerca da prova irritual, LARONGA faz referência ao entendimento que “distingue nettamente la prova atipica della prova tipica assunta irritualmente: altro è la prova atipica ed altro la prova acquisita mediante un mezzo di prova 'tipico' disforme dal modelo legale". 328

Sobre a irritualidade, DEZEM afirma que "a prova que não segue o modelo legal previsto é prova nula e, desta forma, não pode ser confundida com prova atípica".329 "Nesse caso, como ressalta Cavallone, interessa saber se os requisitos previstos em lei para a admissão e a produção de uma prova têm, ou não, caráter essencial e inderrogável". 330

Por fim, despontam as prova nominadas e inominadas.

Segundo DEZEM, “a prova nominada é aquela que se encontra prevista em lei, com ou sem procedimento probatório previsto. Há aqui apenas a previsão do nomen juris do meio de prova", no que cita o exemplo da reconstituição, que se trata de uma prova

\footnotetext{
325 “Ao se juntar aos autos a declaração de uma pessoa que tem ciência de um fato relevante para o processo (fonte de prova), valendo-se para tanto da disciplina legal da prova documental (meio de prova), está se pretendendo atingir a finalidade da prova testemunhal - algume dar ciência ao juiz de um fato que teve conhecimento - com o emprego de prova documental": BADARÓ, Gustavo Henrique Righi Ivahy. Provas atípicas e provas anômalas: inadmissibilidade da substituição da prova testemunhal pela juntada de declarações escritas de quem poderia ser testemunha. In: YARSHELL, Flávio Luiz; MORAES, Maurício Zanoide de (Coord.). Estudos em homenagem à professora Ada Pellegrini Grinover. São Paulo: DPJ Editora, 2005, p. 341-352, p. 347.

${ }^{326}$ DEZEM, Guilherme Madeira. Da prova penal: tipo processual, provas típicas e atípicas. Campinas: Millenium, 2008, p. 153. Para GOMES FILHO, não se trata de nulidade, mas de inadmissibilidade: GOMES FILHO, Antônio Magalhães. Notas sobre a terminologia da prova (reflexos no processo penal brasileiro). In: YARSHELL, Flávio Luiz; MORAES, Maurício Zanoide de (Coord.). Estudos em homenagem à professora Ada Pellegrini Grinover. São Paulo: DPJ Editora, 2005, p. 303-318, p. 315.

${ }_{327}$ GOMES FILHO, Antônio Magalhães. Notas sobre a terminologia da prova (reflexos no processo penal brasileiro). In: YARSHELL, Flávio Luiz; MORAES, Maurício Zanoide de (Coord.). Estudos em homenagem à professora Ada Pellegrini Grinover. São Paulo: DPJ Editora, 2005, p. 303-318, p. 315.

${ }_{328}^{328}$ LARONGA, Antonio. Le prove atipiche nel processo penale. Padova: CEDAM, 2009, p. 13.

${ }^{329}$ DEZEM, Guilherme Madeira. Da prova penal: tipo processual, provas típicas e atípicas. Campinas: Millenium, 2008, p. 154.

${ }^{330}$ GOMES FILHO, Antônio Magalhães. Notas sobre a terminologia da prova (reflexos no processo penal brasileiro). In: YARSHELL, Flávio Luiz; MORAES, Maurício Zanoide de (Coord.). Estudos em homenagem à professora Ada Pellegrini Grinover. São Paulo: DPJ Editora, 2005, p. 303-318, p. 315.
} 
nominada, mencionada expressamente no Código de Processo Penal, art. $7^{\circ}$, mas atípica, dada a inexistência de regras para sua produção probatória. ${ }^{331}$

\subsubsection{A participação da vítima na produção de elementos probatórios}

Tais considerações levam-nos a constatar que a vítima pode ter participação muito relevante e mesmo imprescindível na produção de alguns elementos de prova que sirvam para a formação do convencimento dos sujeitos processuais. Essa participação poderá apresentar cunho mais ativo, quando a vítima presta declarações, procede ao reconhecimento de pessoa (o acusado, normalmente) ou coisa, participa de acareação e de reprodução simulada, ou cunho mais passivo, ao submeter-se a exame pericial.

$\mathrm{Na}$ verdade, a presença e a vontade da vítima, em determinados atos processuais, notadamente destinados à produção de elementos probatórios, parecem constituir um elemento próprio desses atos.

Para um melhor esclarecimento, faz-se mister uma abordagem sobre a tipicidade no âmbito do processo penal, que deverá ser aplicada em matéria de prova para os fins deste tópico.

Segundo DEZEM, a tipicidade processual, que se ligaria à ideia de modelo, apresenta como seus fundamentos os princípios da legalidade e do devido processo legal, ${ }^{332}$ tendo, por âmbito de aplicação, as normas processuais de garantia. ${ }^{333}$

Buscando-lhe uma definição, e partindo da concepção de princípio como mandamento de otimização, DEZEM afirma que a tipicidade processual cuidar-se-ia de um

331 DEZEM, Guilherme Madeira. Da prova penal: tipo processual, provas típicas e atípicas. Campinas: Millenium, 2008, p. 155.

332 DEZEM, Guilherme Madeira. Da prova penal: tipo processual, provas típicas e atípicas. Campinas: Millenium, 2008, p. 50-53.

333 “' [...] as normas processuais podem ser classificadas em normas de garantia e normas de organização. [...] 1) normas de garantia têm por objeto o estabelecimento de direitos e garantias constitucionais; 2) normas de organização têm por objeto outro que não o estabelecimento de direitos e garantias constitucionais. Ora, não há sentido em que se estabeleça a tipicidade processual para todas as normas processuais, sob pena de se cair em um dos extremos abaixo descritos. Em um extremo, haverá tomada absoluta da forma em detrimento do desenvolvimento do processo, pois corre-se o risco de se passar a observar a forma inútil que em nada contribui para o desenvolvimento do processo. Em outro extremo, a tipicidade processual passará a ser apenas mais um exercício de retórica, tendo pouca efetividade no âmbito processual. Ademais, admitindo-se a ideia de que a tipicidade processual atue preponderantemente sobre as normas de garantia, passa-se a pensar o Direito Processual Penal pelo que efetivamente deve ser buscado, ou seja, o implemento dos direitos assegurados constitucionalmente ao cidadão na prática judiciária diária”. (DEZEM, Guilherme Madeira. Da prova penal: tipo processual, provas típicas e atípicas. Campinas: Millenium, 2008, p. 53-54). 
princípio "pelo qual é assegurada a garantia das partes a um processo justo, conduzindo à maior segurança jurídica e previsibilidade na prática dos atos processuais, aplicável preponderantemente às normas de garantia, com respeito máximo à forma útil”. 334

Para o autor ora referido, a tipicidade processual divide-se em tipicidade processual objetiva e tipicidade processual subjetiva. A tipicidade objetiva representa o próprio ato processual, em abstração de sua posição no procedimento, compondo-se em tipicidade objetiva interna e tipicidade objetiva externa.

A tipicidade objetiva interna, por sua vez, abrangeria elementos estruturais, a saber, o verbo da conduta e os elementos normativos, respondendo-se à pergunta $o$ que deve ser feito, e elementos circunstanciais, a saber, lugar e tempo, respondendo-se às perguntas quando e onde deve ser realizado o ato; quanto à tipicidade objetiva externa, essa diria respeito à documentação do ato. ${ }^{335}$

A tipicidade subjetiva, que mais interessa ao presente trabalho, tem dois elementos: um elemento estrutural - o elemento participativo - e um elemento circunstancial - o elemento volitivo.

$\mathrm{O}$ elemento participativo referir-se-ia àqueles que participam de determinado ato processual: a acusação, a defesa e o órgão julgador, e até mesmo demais pessoas que intervenham no processo, como seria o caso da vítima e da testemunha, respondendo-se à pergunta quem intervém no ato praticado.

Quanto ao elemento volitivo, seria tido por circunstancial, dada sua eventualidade, pois nem todos os atos processuais dependeriam da vontade dos sujeitos processuais. O negócio jurídico processual seria sua mais evidente manifestação, o qual, no âmbito do processo penal pode ser identificado em institutos como a suspensão condicional do processo, a transação penal, e mesmo a conciliação no âmbito dos Juizados Especiais Criminais, a qual conta com a manifestação necessária da vontade da vítima do fato.

Deve-se esclarecer que o elemento volitivo se revela em atos processuais ainda que não se cuide de negócio jurídico processual. No campo da prova, pode-se perceber, por exemplo, que as perícias nem sempre dependem da vontade dos sujeitos processuais, como seria o caso da coleta e exame de vestígios no local do crime.

Contudo, perícias que pressuponham o fornecimento de padrão gráfico, por exemplo, dependem da vontade do envolvido. Esse ato processual - perícia grafotécnica -

${ }^{334}$ DEZEM, Guilherme Madeira. Da prova penal: tipo processual, provas típicas e atípicas. Campinas: Millenium, 2008, p. 56-57.

${ }^{335}$ Conferir toda a explanação do autor em relação ao tipo objetivo: DEZEM, Guilherme Madeira. Da prova penal: tipo processual, provas típicas e atípicas. Campinas: Millenium, 2008, p. 59-65. 
não pode, portanto, prescindir, para realizar-se, da vontade do acusado, vítima ou mesmo testemunha em fornecer seu padrão gráfico e, ao mesmo tempo, está longe de cuidar-se de um negócio jurídico.

Dito isso, percebe-se que a participação e a vontade da vítima na produção de elementos probatórios, tomando a classificação de DEZEM, podem consistir em elemento estrutural (elemento participativo) e elemento circunstancial, dada sua eventualidade (elemento volitivo), da tipicidade processual subjetiva, ou em outros termos, elementos imprescindíveis para a configuração de alguns atos processuais destinados à produção de elementos probatórios, tema que constitui objeto deste tópico.

Em face de tal constatação, pode-se identificar a necessidade de participação e de manifestação da vontade da vítima em alguns meios de prova, como por exemplo, as declarações do ofendido (art. 201, do Código de Processo Penal), meio de prova exclusivo para colher o depoimento da vítima, ${ }^{336}$ e em meios de prova outros, não destinados exclusivamente à vítima, como é o caso da perícia, do reconhecimento de pessoas ou coisas, ${ }^{337}$ da acareação e da reconstituição (ou reprodução simulada).

\subsubsection{Considerações sobre a recusa da vítima em participar da produção de elementos probatórios}

Uma vez compreendido que a vítima pode participar na produção de elementos probatórios, havendo até mesmo um meio de prova específico para colher suas declarações, ${ }^{338}$ bem como que sua participação e sua vontade podem constituir elementos integrantes de atos processuais visando àquela finalidade, ${ }^{339}$ despontam aqui os seguintes questionamentos: poderá a vítima recusar-se a participar de tal produção probatória? Se não cabível tal recusa, que medidas poderá o Estado adotar?

\footnotetext{
${ }^{336}$ Deve-se registrar que as declarações do ofendido, reguladas no art. 201, do Código de Processo Penal, não se confundem com o meio de prova testemunhal. Conferir peculiaridades em DEZEM, Guilherme Madeira. Da prova penal: tipo processual, provas típicas e atípicas. Campinas: Millenium, 2008, p. 224-235. Também as diferenças entre vítima e testemunha: FERNANDES, Antônio Scarance. O papel da vítima no processo criminal. São Paulo: Malheiros, 1995, p. 212-213.

${ }^{337}$ Aqui, a vítima pode ser o sujeito do reconhecimento ou seu objeto, mas nas duas hipóteses, a sua presença e sua vontade, tanto em reconhecer como em submeter-se a reconhecimento, mostram-se imprescindíveis à realização do ato.

${ }^{338}$ Disciplinado no art. 201, do Código de Processo Penal.

${ }^{339}$ Elementos participativo e volitivo da tipicidade processual subjetiva, consoante analisado no item 4.5.2.
} 
Para buscar as respostas a esses questionamentos, faz-se necessária uma análise sobre o dever de cooperação processual probatória, ${ }^{340}$ explicitamente previsto no processo civil: "ninguém se exime do dever de colaborar com o Poder Judiciário para o descobrimento da verdade" (art. 319, do Código de Processo Civil) complementado pelos arts. 340 e 341 do mesmo diploma legal. ${ }^{341}$

Comentando o disposto no referido art. 319, FELICIANO anota que a literatura jurídica mais atual aí identifica "um dever geral de cidadania, extensível às partes e aos terceiros, que a todos impele a se colocarem à disposição do juiz e a não impedirem que a ele cheguem os dados relevantes para o julgamento justo da causa". 342 Esse direito implicaria "o comprometimento difuso com a narrativa real dos fatos, a abstenção de embaraços à atividade probatória das partes, a prevenção de controvérsias sobre fatos consabidamente verdadeiros e a exibição e/ou informação de tudo quanto requisitado."343 Lembra, ainda, o autor que, como dever, "acompanha-lhe o correspondente poder de coerção da autoridade judiciária, (exequível, em teses, sempre que à cooperação se recuse a pessoa a tanto instada)."

Observe-se que, atendendo ao disposto no art. $3^{\underline{0}}$, do Código de Processo Penal (“A lei processual penal admitirá interpretação extensiva e aplicação analógica, bem como o suplemento dos princípios gerais de direito"), o qual permite a integração analógica dos dispositivos legais do processo civil no processo penal, esse dever de cooperação processual probatória também vige no processo penal, podendo ser identificado, no âmbito da regulamentação da produção probatória testemunhal, no art. 206, do Código de

\footnotetext{
${ }^{340}$ É possível distinguir o dever de cooperação processual em sua acepção lata, que se estende a todas as fases do processo, incumbindo a todos indistintamente (juízes, serventuários da justiça, partes e terceiros intervenientes acidentais), do dever de cooperação em sua acepção estrita, que seria o caso do dever de cooperação processual em matéria probatória, que impõe às pessoas em geral, sejam partes ou não, o dever de colaborar com a descoberta da verdade no processo. (FELICIANO, Guilherme Guimarães. Direito à prova e dignidade humana: cooperação e proporcionalidade em provas condicionadas à disposição física da pessoa humana (abordagem comparativa). São Paulo: LTr, 2007, p. 38-39).

341 "Art. 340. Além dos deveres enumerados no art. 14, compete à parte: I - comparecer em juízo, respondendo ao que Ihe for interrogado; II - submeter-se à inspeção judicial, que for julgada necessária; III praticar o ato que Ihe for determinado".

"Art. 341. Compete ao terceiro, em relação a qualquer pleito: I - informar ao juiz os fatos e as circunstâncias, de que tenha conhecimento; II - exibir coisa ou documento, que esteja em seu poder".

342 FELICIANO, Guilherme Guimarães. Direito à prova e dignidade humana: cooperação e proporcionalidade em provas condicionadas à disposição física da pessoa humana (abordagem comparativa). São Paulo: LTr, 2007, p. 55.

343 FELICIANO, Guilherme Guimarães. Direito à prova e dignidade humana: cooperação e proporcionalidade em provas condicionadas à disposição física da pessoa humana (abordagem comparativa). São Paulo: LTr, 2007, p. 55.

344 FELICIANO, Guilherme Guimarães. Direito à prova e dignidade humana: cooperação e proporcionalidade em provas condicionadas à disposição física da pessoa humana (abordagem comparativa). São Paulo: LTr, 2007, p. 39.
} 
Processo Penal, que prevê a regra da obrigação de depor imposta às testemunhas em geral (“a testemunha não poderá eximir-se da obrigação de depor. [...]”).

Assim, também à vítima, esteja ou não habilitada como assistente no processo penal, se impõe o dever de cooperação processual probatória, não podendo aquela, a princípio, recusar-se a colaborar na produção de elementos de prova.

Caso haja eventual recusa pela vítima, impende atentar que a adoção de medidas desfavoráveis certamente haverão de gerar-lhe um segundo processo de vitimização, configurando-se a vitimização secundária, já referida neste trabalho. Entra em cena, então, o Princípio da Dignidade da Pessoa Humana, que também se estende à pessoa da vítima no processo penal, exigindo um tratamento diferenciado quanto a esta.

Dessa forma, em face da recusa da vítima em colaborar com a produção probatória, deve-se, a princípio, tentar suprir a lacuna probatória com outros elementos de prova, como preceitua FERNANDES ao referir-se à prova pericial ${ }^{345}$ - o que não impede a aplicação de suas colocações em relação a outros meios de prova -, destacando-se a possibilidade, de se proceder ao exame de corpo de delito indireto, previsto no art. 167, do Código de Processo Penal, ${ }^{346}$ equiparando-se, assim, na espécie, o desparecimento de vestígios à recusa da vítima.

Caso não seja possível esse suprimento por outro meio de prova, o próprio FERNANDES advoga a aplicação do disposto no art. 201, $\S 1^{\circ}$, do Código de Processo Penal $^{347}$ ("se, intimado para esse fim, deixar de comparecer sem motivo justo, o ofendido poderá ser conduzido à presença da autoridade"), que permite a condução coercitiva da vítima, possibilitando-se, dessarte, sua presença física.

Sobre tal dispositivo (art. $201 \S 1^{\circ}$, do Código de Processo Penal), cabem algumas ponderações. Embora seja previsto especificamente para a ausência da vítima quando da sua oitiva em audiência de instrução e julgamento, pode ser aplicado, na medida do possível, como parâmetro para outras situações em que a vítima se negue a colaborar; deve-se registrar também que sua aplicabilidade parece restringir-se a processos

\footnotetext{
345 "Um caminho constituiria em coagir o ofendido a colaborar, constrangendo-o como uso de força a se submeter ao exame. Com isso, prevaleceria o interesse público na demonstração a verdade, mas, de regra, o custo seria excessivo para a vítima, a qual sofreria uma segunda vitimização. [...] Não é, portanto a solução conveniente. Outra forma consistiria em se suprir a falta da perícia por outros meios de prova - testemunhas, documentos -, prescindindo-se, então, da constatação direta da ofensa à vítima". (FERNANDES, Antônio Scarance. O papel da vítima no processo criminal. São Paulo: Malheiros, 1995, p. 217).

346 “Art. 167. Não sendo possível o exame de corpo de delito, por haverem desaparecido os vestígios, a prova testemunhal poderá suprir-lhe a falta”.

${ }^{347}$ Conferir: FERNANDES, Antônio Scarance. O papel da vítima no processo criminal. São Paulo: Malheiros, 1995 , p. 218 . Esse $\S 1^{\circ}$ correspondia ao parágrafo único antes das alterações operadas pela Lei n. $11.690 / 08$.
} 
instaurados a partir de ação penal de iniciativa pública, já que em se tratando de ação penal de iniciativa privada, a não cooperação da vítima implicará perempção (art. 60, III, do Código de Processo Penal), ${ }^{348}$ que constitui causa extintiva de punibilidade.

Por fim, perceba-se que a Lei faz referência a um motivo justo sem o qual seu não comparecimento pode ensejar a condução coercitiva (art. 201, §1 ${ }^{\circ}$ ). De fato, caso a vítima justifique a recusa, sua presença pode deixar de ser exigível na situação concreta. Lembra FERNANDES que a vítima pode sofrer riscos graves e não haver como se lhe garantir proteção, ${ }^{349}$ situação que pode ocorrer caso não sejam viabilizados, de forma imediata e satisfatória, mecanismos que assegurem o direito à proteção da segurança da vítima. Tal hipótese demandará a adoção das providências cabíveis para assegurar o direito à proteção, possibilitando-se, assim, a cooperação da vítima. Mesmo assim, em caso de impossibilidade de remoção da situação fática que enseja o motivo justificador apresentado pela vítima, não se poderá conduzir a esta coercitivamente nem se lhe impor qualquer tipo de sanção.

E se, na ausência de motivo justo, conduzida coercitivamente, assegurando-se sua presença física, a vítima recusar-se a praticar os atos necessários para a produção dos elementos probatórios, opondo-se, por exemplo, a prestar declarações em audiência, a proceder a reconhecimento de pessoas ou coisas, a fornecer material para exame pericial ou a participar de reprodução simulada dos fatos?

Deve-se registrar que os direitos da vítima, assim como quaisquer outros direitos dispostos no ordenamento jurídico, o que vale, inclusive, em relação ao acusado em processo penal, não podem ser tomados como se absolutos fossem, devendo submeterse a alguma relativização. Dessarte, a proteção que se impõe à vítima não poderá, em algumas situações, sobrepor-se aos interesses sociais afetados quando da prática de infrações penais, o que demanda a atuação de um poder coercitivo estatal.

No caso, não existindo como suprir os elementos probatórios desejados, e não havendo justo motivo para a recusa da vítima em cooperar, a esta deve ser dada ciência de que sua recusa constitui, em tese, crime de desobediência (art. 330, do Código Penal), ensejando ainda, por analogia, infração a dever processual, que poderá lhe acarretar o

\footnotetext{
348 “Art. 60. Nos casos em que somente se procede mediante queixa, considerar-se-á perempta a ação penal: [...] III - quando o querelante deixar de comparecer, sem motivo justificado, a qualquer ato do proc esso a que deva estar presente, ou deixar de formular o pedido de condenação nas alegações finais".

${ }^{349}$ FERNANDES, Antônio Scarance. O papel da vítima no processo criminal. São Paulo: Malheiros, 1995 , p. 219.
} 
pagamento de multa (integração por analogia dos arts. 219, 436 e 458, do CPP, ${ }^{350}$ dispositivos estes aplicáveis, a princípio, à testemunha).

Além da condução coercitiva e, subsidiariamente, das sanções referidas no parágrafo anterior (sanção penal e multa processual), não entendemos possível, à luz do atual ordenamento jurídico, a constrição física da vítima para produção de elementos probatórios, por motivo de qualquer ordem. Assim, a vítima pode ser conduzida à audiência, mas pode optar por ficar silente, ou, pode ser conduzida a realizar exame pericial, porém, negando-se a submeter-se à extração de sangue ou de DNA.

Nesses casos, ser-lhe-ão impostas as sanções penais e processuais cabíveis. Tal intepretação visa a uma relativização dos direitos da vítima, evitando-se, de um lado, abuso da parte desta, e de outro, um processo de vitimização de cunho mais grave. ${ }^{351}$

350 "Art. 219. O juiz poderá aplicar à testemunha faltosa a multa prevista no art. 453 , sem prejuízo do
processo penal por crime de desobediência, e condená-la ao pagamento das custas da diligência";
"Art. 436 . O serviço do júri é obrigatório. O alistamento compreenderá os cidadãos maiores de 18 (dezoito)
anos de notória idoneidade. [...] § 20 A recusa injustificada ao serviço do júri acarretará multa no valor de 1
(um) a 10 (dez) salários mínimos, a critério do juiz, de acordo com a condição econômica do jurado";
"Art. 458. Se a testemunha, sem justa causa, deixar de comparecer, o juiz presidente, sem prejuízo da ação
penal pela desobediência, aplicar-lhe-á a multa prevista no $§ 2$ do art. 436 deste Código".
351 A título de informação, o CPPN argentino também evita a constrição física da vítima para exames de
amostra de DNA. Nesse sentido, dispõe o art. 218 bis, acrescentado pela Ley n. 26.549 , de 27.11 .2009 , em
seu último parágrafo:
"Art. 218 bis. - Obtención de ácido desoxirribonucleico (ADN). El juez podrá ordenar la obtención de ácido
desoxirribonucleico (ADN), del imputado o de otra persona, cuando ello fuere necesario para su
identificación o para la constatación de circunstancias de importancia para la investigación. La medida
deberá ser dictada por auto fundado donde se expresen, bajo pena de nulidad, los motivos que justifiquen su
necesidad, razonabilidady proporcionalidad en el caso concreto.
Para tales fines, serán admisibles mínimas extracciones de sangre, saliva, piel, cabello u otras muestras
biológicas, a efectuarse según las reglas del saber médico, cuando no fuere de temer perjuicio alguno para
la integridad fisica de la persona sobre la que deba efectuarse la medida, según la experiencia común y la
opinión del experto a cargo de la intervención.
La misma será practicada del modo menos lesivo para la persona y sin afectar su pudor, teniendo
especialmente en consideración su género y otras circunstancias particulares. El uso de las facultades
coercitivas sobre el afectado por la medida en ningún caso podrá exceder el estrictamente necesario para su
realización. Si el juez lo estimare conveniente, y siempre que sea posible alcanzar igual certeza con el resultado de la medida, podrá ordenar la obtención de ácido desoxirribonucleico $(A D N)$ por medios distintos a la inspección corporal, como el secuestro de objetos que contengan células ya desprendidas del cuerpo, para lo cual podrán ordenarse medidas como el registro domiciliario o la requisa personal.

Asimismo, cuando en un delito de acción pública se deba obtener ácido desoxirribonucleico (ADN) de la presunta víctima del delito, la medida ordenada se practicará teniendo en cuenta tal condición, a fin de evitar su revictimización y resguardar los derechos específicos que tiene. A tal efecto, si la víctima se opusiera a la realización de las medidas indicadas en el segundo párrafo, el juez procederá del modo indicado en el cuarto párrafo.

En ningún caso regirán las prohibiciones del artículo 242 y la facultad de abstención del artículo 243". (destaques nossos). 


\title{
5 DIREITO DA VÍTIMA À PARTICIPAÇÃO: CONCURSO OU COOPERAÇÃO
}

\author{
5.1 NOÇÕES GERAIS
}

Conforme já visto, a vítima perdeu seu protagonismo no processo penal, sendo neutralizada pelo Estado, que não somente assumiu o monopólio da jurisdição penal, como se ocupou da titularidade do ius accusationis.

No Brasil, especificamente, a influência portuguesa no período de colonização já imprimia ao processo penal um sistema fortemente inquisitorial, de tradição canônica, em que a vítima, na prática, limitava-se a provocar a atuação da justiça penal. ${ }^{352}$

O passar do tempo apenas consolidou o expurgo da vítima e a estatização do ius accusationis, que passou pelas mãos de juízes de paz e mesmo de autoridades policiais até chegar, em definitivo, em 1988, às mãos do Ministério Público, mediante a consagração do sistema acusatório, conforme o disposto no art. 129, inciso I, da Constituição Federal. ${ }^{353}$

Por força do movimento vitimológico, passou-se a clamar por uma participação mais direta da vítima no processo penal, vislumbrando FERNANDES três modalidades para tal participação: a) auxiliar da acusação, que é o caso do assistente do direito

\footnotetext{
352 “O processo inquisitorio transportava a acção publica das mãos das partes para as do juiz; dava ao juiz o poder, não mais de julgar sómente, mas o de dirigir e provocar ex-officio os actos da instrucção; essencialmente secreto, este processo não faz pesar responsabilidade alguma sobre o inquiridor. A accusação também se transformou: não mais era feita segundo as fórmas romanas; as partes, certas de que a denuncia bastava para pôr o juiz em movimento, limitaram-se a isso ou, quando muito, auxiliavam o juiz ou o inquiridor na pesquiza de provas; e, assim estabelecido o processo escripto, a accusação formal da parte ou da justiça, por um promotor, só foi estabelecida para depois que a formação da culpa, feita inquisitorialmente, em processo summario, iniciado ou por inquirição secreta nos casos de devassa, ou por querela do offendido, ou de qualquer do povo no interesse publico, estivesse encerrada. Só dahi em diante, posto que em forma escripta, seguia-se um processo aberto ou ordinario, como no civel, com libello, contestação, replica, treplica, dilação e provas, allegações finaes, podendo haver a defesa e perguntas ao réo em qualquer estado da causa antes das allegações finaes da sentença." (ALMEIDA JÚNIOR, João Mendes de. O processo criminal brasileiro. 3. ed. augmentada. Rio de Janeiro: Typ. Baptista de Souza, 1920. v. 1, p. 248-249).

${ }^{353}$ Para uma abordagem histórica sobre o tema, cf.: ALMEIDA JÚNIOR, João Mendes de. O processo criminal brasileiro. 3. ed. augmentada. Rio de Janeiro: Typ. Baptista de Souza, 1920. v. 1., p. 151-243; AZEVEDO, Rodrigo Ghiringhelli de. O Ministério Público no Brasil. In: DIAS, João Paulo; AZEVEDO, Rodrigo Ghiringhelli de. (Coord.). O papel do ministério público: estudo comparado dos países latinoamericanos. Coimbra: Almedina, 2008. p. 223-248; PENTEADO, Jaques Camargo. Acusação, defesa e julgamento. Campinas: Millenium, 2001. p. 45-56.
} 
brasileiro; ${ }^{354}$ b) acusação conjunta, em que a vítima formula acusação própria que é acrescida à acusação oficial; e c) parte civil, em que embora seja postulada a reparação de danos civis, a atuação da vítima pode influenciar na condenação penal do acusado. ${ }^{355}$

A assistência encontra-se prevista atualmente no Código de Processo Penal, em seus artigos 268 a 273, podendo ser exercida em todos os termos da ação de iniciativa pública pelo ofendido ou seu representante legal, ou, na falta, por qualquer das pessoas mencionadas no art. 31 (art. 268).

No presente capítulo, principia-se com uma análise sobre a figura do assistente conforme a atual configuração do processo penal brasileiro, tratando-se, nesse intuito, de questionamentos relativos à matéria, como a busca por uma categorização jurídica do assistente, seus interesses, legitimidade, habilitação no processo e, por fim, mas não menos importante, suas atribuições atuais.

Após tal visão panorâmica do assistente sob a atual realidade processual brasileira, passa-se ao item das novas perspectivas, em que se analisarão inicialmente perspectivas de direito comparado, bem como perspectivas relativas a órgãos internacionais (CIDH e TPI), pouco referidas na literatura jurídica nacional, o que servirá como suporte para considerações posteriores, que tratarão de temas a partir dos quais se desenvolverão as sugestões para o aperfeiçoamento da figura do assistente no processo penal brasileiro.

Ao final, tratar-se-á da configuração do instituto da assistência no projeto de Código de Processo Penal em tramitação no Congresso Nacional.

\subsection{O CONCURSO (OU COOPERAÇÃO) NO ATUAL PROCESSO PENAL BRASILEIRO: O ASSISTENTE}

\subsubsection{Buscando uma categoria jurídica: parte ou terceiro?}

\footnotetext{
354 Para uma análise sobre a origem do instituto da assistência no processo penal brasileiro, cf. FERNANDES, Antônio Scarance. O papel da vítima no processo criminal. São Paulo: Malheiros, 1995, p. 130-134.

${ }^{355}$ FERNANDES, Antônio Scarance. O papel da vítima no processo criminal. São Paulo: Malheiros, 1995 , p. 122.
} 
Um questionamento que se coloca consiste em saber se, no processo penal, o assistente se trata de parte ou de terceiro. Analisando a questão, FERNANDES descarta sua categorização como parte principal ou como litisconsorte ativo, em razão de aquele não exercer a ação penal, definindo-o como "terceiro interveniente voluntário que auxilia o Ministério Público"; ${ }^{356}$ LOPES JÚNIOR endossa a categorização do assistente como parte contingente ou secundária, já que "é uma parte, mas não principal, pois sua atividade processual é acessória em relação àquela desenvolvida pela parte principal, que é o Ministério Público"; ${ }^{357}$ por sua vez, TUCCI, reconhecendo a intervenção do assistente $a d$ adiuvando tantum, rejeita sua qualificação como parte ainda que em sentido processual. ${ }^{358}$

Para uma melhor análise da questão, deve-se indagar primeiramente o que distingue a parte do terceiro? A resposta pode ser obtida junto a MARINONI e ARENHART, para quem a parte será “aquele que demandar em seu nome (ou em nome de quem for demandada) a atuação de uma ação de direito material e aquele outro em face de quem essa ação deva ser atuada", e o terceiro "será, por exclusão, aquele que não efetivar semelhante demanda no processo, mas por ter interesse jurídico próprio na solução do conflito (ou, ao menos, afirmar possuí-lo), é autorizado a dele participar sem assumir a condição de parte". 359

Em conformidade com esses termos, o assistente encontraria enquadramento na condição de terceiro, pois, na verdade, não demandaria no processo, apenas atuando em colaboração com o Ministério Público, este sim, o verdadeiro demandante.

XAVIER DE ALBUQUERQUE, traçando um paralelo entre a assistência no processo penal e a assistência prevista no processo civil, chega a indagar se a assistência processual penal seria simples ou litisconsorcial, ao que o próprio autor, embora defenda a possibilidade de caracterização de ambas as hipóteses, conclui carecer de maior relevância prática no sistema brasileiro. ${ }^{360}$

Contudo, uma observação se faz importante sobre o questionamento inicialmente formulado (se o assistente é parte ou terceiro no processo penal). É que essa

\footnotetext{
${ }^{356}$ Cf. FERNANDES, Antônio Scarance. O papel da vítima no processo criminal. São Paulo: Malheiros, 1995 , p. 135-136.

${ }^{357}$ LOPES JÚNIOR, Aury. Direito processual penal e sua conformidade constitucional. 5. ed. rev. atual. Rio de Janeiro: Lumen Juris, 2010, v 2, p. 40.

${ }^{358}$ TUCCI, Rogério Lauria. Direitos e garantias individuais no processo penal brasileiro. 3. ed. rev. atual. amp. São Paulo: Revista dos Tribunais, 2009, p. 133-134.

359 MARINONI, Luiz Guilherme. Técnica processual e tutela dos direitos. 3. ed. rev. atualiz. São Paulo: Revista dos Tribunais, 2010, p. 163.

${ }^{360}$ XAVIER DE ALBUQUERQUE, F.M. A assistência no processo penal brasileiro. Revista brasileira de criminologia e direito penal, Rio de Janeiro, v. 3, n. 12, p. 89-98, jan./mar. 1966, p. 89-92.
} 
indagação tem por base categorias jurídicas desenvolvidas originariamente no âmbito do processo civil, merecendo a devida ponderação.

De fato, o conceito de parte, a princípio, remete à ideia de pretensão e de lide, conceitos esses formulados por CARNELUTTI, podendo ser definidos, respectivamente, como "exigência de submissão do interesse alheio ao interesse próprio" e "conflito de interesses qualificado por uma pretensão resistida". 361

Ocorre que tais conceitos em sua acepção civilística não apresentam qualquer relevância em termos de jurisdição penal e, mais ainda, não lhe são sequer aplicáveis. $\mathrm{O}$ próprio CARNELUTTI, que inicialmente admitia a pretensão penal como a exigência da sujeição de alguém a uma pena, corrigiu seu posicionamento com base nas seguintes razões: uma exigência somente se colocaria em face de alguém que a deva satisfazer, ao passo que o Ministério Público não pode exigir sponte propria o cumprimento da pena ao imputado; ademais, o próprio imputado não poderia cumprir voluntariamente o castigo penal. $^{362}$

Essas ponderações fazem exsurgir o tema da autonomia do processo penal em relação ao processo civil. ${ }^{363}$ Para tanto, deve-se levar em conta que a jurisdição penal mostra-se bem distinta da jurisdição civil. De fato, a jurisdição penal apresenta peculiaridades que escapam ao que se entende por jurisdição civil.

TUCCI aponta algumas das peculiaridades referidas, como a irrelevância da existência de uma lide, a necessária presença de interesses públicos - ius puniendi e direito cívico de liberdade do cidadão -, o contraditório real, efetivo e indisponível, a coisa julgada sui generis - cujos contornos variam conforme a natureza do ato decisório por ela tutelado -, tudo a demonstrar, à evidência, "que a jurisdição penal não se identifica, também, com a jurisdição tida por contenciosa (própria do processo extrapenal, especialmente do processo civil)", 364 nem tampouco se identifica com a jurisdição

\footnotetext{
${ }^{361}$ CARNELUTTI, Francesco. Instituições do processo civil. Tradução de Adrián Sotero De Witt Batista. Campinas: Servanda, 1999. v. 1, p.78.

362 TUCCI, Rogério Lauria. Teoria do direito processual: jurisdição, ação e processo penal (estudo sistemático). São Paulo: Revista dos Tribunais, 2002, p. 36.

${ }^{363}$ LOPES JÚNIOR discorre sobre o tema da autonomia do processo penal em relação ao processo civil, sob o item entitulado Quando Cinderela terá suas Própias Roupas? Respeitando as Categorias Jurídicas Próprias do Processo Penal (ou Abandonando a Teoria Geral do Processo), em que faz alusão ao artigo de CARNELUTTI que compara o processo penal à irmã mais pobre da fábula Cenerentola (Cinderela). (LOPES JÚNIOR, Aury. Direito processual penal e sua conformidade constitucional. 5. ed. rev. atual. Rio de Janeiro: Lumen Juris, 2010. v. 1, p. 33-36). No mesmo sentido, cerrando fogo contra uma teoria geral do processo: DIAS, Jorge de Figueiredo. Direito processual penal. 1. ed. 1974, reimpressão. Coimbra: Coimbra editora, 2004, p. 51-58.

364 TUCCI, Rogério Lauria. Teoria do direito processual: jurisdição, ação e processo penal (estudo sistemático). São Paulo: Revista dos Tribunais, 2002, p. 52.
} 
voluntária extrapenal. ${ }^{365}$

Nessa perspectiva, o processo penal, como afirmado por TUCCI, versa necessariamente sobre o ius puniendi e o ius libertatis, servindo como instrumento necessário para fazer valer a preponderância de um sobre o outro, algo absolutamente alheio à concepção de processo civil. Quando se busca especificamente a tutela condenatória penal - hipótese mais frequente no processo penal - esse processo se torna uma instância formal de controle social, uma verdadeira condição sine qua non para o Estado aplicar sanções penais.

Registradas tais advertências, nada impede, porém, sejam aproveitadas algumas categorias jurídicas inicialmente desenvolvidas sob a égide do processo civil, redesenhando-as em consonância com a realidade do processo penal. Em relação à parte, assim o faz, por exemplo, LOPES JÚNIOR, que afasta a vinculação do conceito de parte da concepção civilistica, redefinindo-o. Para o autor, seriam partes "aquele que formula e aquele contra quem se formula a pretensão acusatória objeto do processo penal, segundo as formas previstas na norma processual penal e tendo como destinatário o órgão jurisdicional". 366

Tornando à questão que constitui o objeto deste item, uma resposta mais direta somente poderá ser trazida após o desenvolvimento das proposições deste estudo. ${ }^{367} \mathrm{De}$ qualquer forma, pode-se afirmar desde já que o questionamento ora levantado apresenta relevantes benefícios para o presente estudo: primeiramente, proporciona-se uma reflexão sobre a autonomia do processo penal em relação ao processo civil, o que envolve a necessidade de elaboração de categorias jurídicas mais apropriadas às peculiaridades do processo penal; em consequência, desperta a necessidade de uma abordagem da figura do assistente condizente com as peculiaridades do processo penal, devendo-se delinear-lhe uma identidade própria.

\subsubsection{A questão dos interesses}

\footnotetext{
${ }^{365}$ Quanto ao argumento de identificação da jurisdição penal com a jurisdição voluntária civilística, o autor o rejeita por absurdo, lembrando que o processo penal versa sobre a resolução de importante conflito de interesses públicos, o ius puniendi e o ius libertatis. Cf. TUCCI, Rogério Lauria. Teoria do direito processual: jurisdição, ação e processo penal (estudo sistemático). São Paulo: Revista dos Tribunais, 2002, p. 46-48.

${ }^{366}$ LOPES JÚNIOR, Aury. Direito processual penal e sua conformidade constitucional. 5. ed. rev. atual. Rio de Janeiro: Lumen Juris, 2010, v.1, p. 5.

${ }^{367}$ Cf. item 5.3.6.
} 
Outro questionamento se impõe quanto ao assistente, merecendo uma análise mais detida para os fins do presente estudo: qual seria o interesse a justificar a intervenção do ofendido na qualidade de assistente?

FERNANDES chega a identificar duas correntes distintas ${ }^{368}$ : a) interesse na reparação do dano, de modo a obstar sentença absolutória que lhe impeça a provocação da via civil ou obter a sentença penal condenatória, evitando-se a discussão do tema no juízo cível e valendo-lhe como título executivo judicial. Dessa corrente fariam parte juristas como FERNANDO DA COSTA TOURINHO FILHO, ROMEU PIRES DE CAMPOS BARROS e CANUTO MENDES DE ALMEIDA; b) forma de colaboração com o Ministério Público e de, ao mesmo tempo, suprir suas omissões, visando à correta e justa atuação da lei penal, da qual fariam parte expoentes, como JOSÉ FREDERICO MARQUES, EDUARDO ESPÍNOLA FILHO, HÉLIO TORNAGHI, WALTER P. ACOSTA, EDGARD MAGALHÃES NORONHA, VICENTE GRECO FILHO, JÚLIO F. MIRABETE e ROGÉRIO L. TUCCI.

A primeira corrente conta ainda com o endosso de LOPES JÚNIOR, o qual não consegue vislumbrar, como interesses do assistente, nada além de sentimento de vingança elou interesse econômico, questionando a alegação de que o assistente teria interesse em fazer justiça ou contribuir para esta, ${ }^{369}$ bem como de OLIVEIRA, para quem "as hipóteses de assistência no processo penal estão condicionadas à existência de um interesse jurídico não-penal que possa ser particularizado, isto é, somente cabível para infrações penais que produzam danos mensuráveis ao nível do interesse individual", 370

O próprio FERNANDES defende a segunda corrente, argumentando pela existência, em prol da vítima, de interesses jurídicos diversos do interesse na reparação do dano, tais como o de querer a aplicação da pena para aquele que atingiu bem jurídico seu, ao cometer a infração penal, o fato de o processo penal analisar aspectos de seu

\footnotetext{
${ }^{368}$ FERNANDES, Antônio Scarance. O papel da vítima no processo criminal. São Paulo: Malheiros, 1995, p. 136-137.

369 "Deixando os frágeis argumentos teóricos de lado, como regra, a assistência da acusação é motivada por sentimento de vingança e/ou interesse econômico. Bastante frágil é a alegação de que o assistente está interessado em 'fazer (ou contribuir para a) justiça', pois que conceito de justiça é esse que somente se conforma com uma sentença condenatória? Falar em 'sentença justa', nesse caso, é recorrer a um conceito vago, que oculta, no fundo, uma visão unilateral e vingativa, pois tal 'sentença justa' somente existe quando condenatória. Sim, porque ninguém se habilita como assistente para postular a absolvição do acusado." (destaques do autor). (LOPES JÚNIOR, Aury. Direito processual penal e sua conformidade constitucional. 5. ed. rev. atual. Rio de Janeiro: Lumen Juris, 2010, v. 2, p. 41).

370 OLIVEIRA, Eugênio Pacelli. Processo e hermenêutica na tutela penal dos direitos fundamentais. 2. ed. rev. atual. Rio de Janeiro: Lumen Juris, 2009, p. 106.
} 
comportamento, o que, dependendo da decisão, pode afetar interesses seus como a dignidade, a honra, o prestigio etc.; asseguramento de sua segurança pessoal em face do autor da infração penal; evitar o perigo de uma acusação por denunciação caluniosa, quando a provocação do sistema de justiça penal tenha partido dela vítima. ${ }^{371}$

Cabe ressaltar aqui um dos interesses jurídicos mencionados por FERNANDES, que se reveste de monumental importância: a coadunação da assistência com a visão democrática do Estado e do processo, tratando-se de instrumento para que o cidadão (vítima) e órgãos de defesa de interesses difusos e coletivos possam influenciar nas decisões do Poder Judiciário. ${ }^{372}$ De fato, a participação da vítima e de órgãos que atuem na defesa de interesses metaindividuais violados pela infração penal, representa grandes benesses, como a contribuição para o enriquecimento do diálogo processual, assim como o reforço à legitimidade do provimento jurisdicional marcado sob o contraditório ${ }^{373}$.

Ditos interesses jurídicos diversos do interesse da reparação do dano justificam, para FERNANDES, a atuação do assistente no processo penal. Para o referido autor, o ordenamento jurídico brasileiro permite tal interpretação, como o prova a instituição da ação penal de iniciativa privada subsidiária ${ }^{374}$, bem como a disponibilização, em favor do assistente, de recursos que possam impugnar decisões que não vedam a via civil, como o recurso em sentido estrito para decisões de impronúncia ${ }^{375}$ ou de declarações de prescrição penal ${ }^{376}$.

As ponderações de FERNANDES mostram-se, para nós, bastante acertadas, não merecendo retoque. Na verdade, a imposição de uma concepção em que se restrinja a participação da vítima sob a ótica de interesses cíveis patrimoniais, além de basear-se em

\footnotetext{
${ }^{371}$ FERNANDES, Antônio Scarance. O papel da vítima no processo criminal. São Paulo: Malheiros, 1995, p. 124.

${ }^{372}$ FERNANDES, Antônio Scarance. O papel da vítima no processo criminal. São Paulo: Malheiros, 1995, p. $123-124$

373 "Resta evidente, portanto, que o processo penal possui um lugar e uma função na democracia, a saber, um espaço de diálogo em que o contraditório deve ser garantido. É a partir do contraditório que se estabelece a legitimidade do provimento judicial. [...]. O que importa é (r)estabelecer um espaço democrático no processo penal brasileiro, superando a visão prevalecente, na qual o ritual e a postura inquisitória ceifam qualquer possibilidade de democracia processual, no que Fazzalari pode ser um sendero". (ROSA, Alexandre Moraes da; SILVEIRA FILHO, Sylvio Lourenço da. Para um processo penal democrático: crítica à metástase do sistema de controle social. Rio de Janeiro: Lumen Juris, 2008, p. 96-97).

374 "Ainda, não se entenderia por que o ofendido, como substituto processual, teria ampla possibilidade de acusar e buscar a punição em qualquer crime de ação pública, quando ficasse inerte o Ministério Público, independentemente de evidenciar interesse civil, em face de autorização expressa do Código de Processo Penal (art. 29) e por força de dispositivo constitucional (art. $5^{\circ}$, LIX, da CF), mas devesse, para auxiliar a acusação, comprovar que está impulsionado por motivação pecuniária". (FERNANDES, Antônio Scarance. O papel da vítima no processo criminal. São Paulo: Malheiros, 1995, p. 137).

${ }^{375} \mathrm{O}$ recurso para tal decisão agora é o de apelação, na esteira das alterações trazidas pela Lei n. 11.689/08.

${ }^{376}$ FERNANDES, Antônio Scarance. O papel da vítima no processo criminal. São Paulo: Malheiros, 1995, p. 137-138.
} 
subjetivismo que está além do alcance do Direito, ${ }^{377}$ peca pelo reducionismo. ${ }^{378}$

Para SANTOS, a própria lógica de separação das questões penais e cíveis deve ser combatida, por não alcançar interesses outros da vítima que podem não satisfazer-se com uma reparação ou com a aplicação de uma pena, bem como em razão de essa cisão constituir empecilho para uma reação única ao crime, ao mesmo tempo punitiva e reparadora. ${ }^{379}$

$\mathrm{Na}$ verdade, as exigências do estágio atual do movimento vitimológico acenam para um raciocínio fulcrado no Princípio da Dignidade da Pessoa Humana, fazendo-se necessária uma nova perspectivação da participação da vítima no processo, a qual deve justificar-se a partir da própria dignidade daquela, almejando-se a prevenção de novos processos de vitimização e a promoção da solução efetiva do caso. ${ }^{380}$

Não se pode tentar levar a cabo tais propósitos, todavia, utilizando-se de pensamentos que, ao fim, restrinjam, condicionem e mesmo deturpem o direito de participação processual da vítima.

\subsubsection{Legitimidade e habilitação}

Estabelece o Código de Processo Penal, em seu art. 268: "Em todos os termos da ação pública, poderá intervir, como assistente do Ministério Público, o ofendido ou seu

\footnotetext{
${ }^{377}$ Em verdade, a busca por uma precisa distinção entre interesses civis e os demais interesses da vítima no tocante à atuação processual desta mostra-se baseada em claro subjetivismo, intagível pela ciência jurídica. De fato, em sede de um processo penal, não há como se assegurar que o assistente esteja a atuar em defesa de interesse civil ou não. Nada impede, por exemplo, que a vítima desenvolva a assistência no processo buscando satisfazer seu interesse civil e no decorrer da marcha procedimental, abandone seu interesse de reparação de dano, satisfazendo-se com interesses outros de conteúdo não civil.

378 "Limitar-se o interesse da vítima ao ressarcimento do dano como única forma de satisfação na proteção ao bem jurídico é ideia assentada numa visão capitalista e patrimonialista." (SALIBA, Marcelo Gonçalves. Justiça restaurativa e paradigma punitivo. Curitiba: Juruá, 2009, p. 118).

379 "A esta tão confortavelmente arrumada lógica de separação das questões penais e cíveis talvez, possam, porém, opor-se dois argumentos principais: (I) existem necessidades das vítimas que não logram ter uma resposta através da soma da condenação do agente a uma pena e da condenação do agente ao pagamento de uma indemnização; (II) a cisão entre aquelas duas distintas formas dificulta a aplicação ao agente de uma única reação ao crime que seja simultaneamente punitiva e reparadora, sendo que esta reação púnica poderia - por razões várias que não cabe nesse contexto desenvolver - contribuir para tornar o sistema punitivo menos severo e criminógeno para o agente do crime e mais satisfatório para a vítima do crime." (SANTOS, Cláudia Cruz. A "redescoberta" da vítima e o direito processual penal português. In: ANDRADE, Manuel da Costa Andrade; ANTUNES, Maria João; SOUSA, Susana Aires de. (Org.). Estudos em homenagem ao prof. doutor Jorge de Figueiredo Dias. Coimbra: Coimbra Editora, 2010. v. 3. p. 1133-1153, p. 1140).

${ }^{380}$ A atuação da vítima no processo penal deve justificar-se sob a necessidade de afirmação e resgate da dignidade da vítima, em obediência às emanações do Princípio da Dignidade da Pessoa Humana, o qual, por sua vez, assegura à vítima da infração penal o direito fundamental à tutela jurisdicional efetiva.
} 
representante legal, ou, na falta, qualquer das pessoas mencionadas no Art. 31”.

Essa, pois a regra geral quanto à legitimação: o primeiro legitimado a intervir como assistente no processo penal é o ofendido, assim entendido o titular do interesse jurídico-penal protegido pela norma penal violada e, caso seja menor de 18 anos de idade, a legitimidade caberá a seu representante legal.

Nas hipóteses de morte ou ausência do ofendido, surge a possibilidade de legitimação supletiva, atribuível, ao cônjuge, convivente, ${ }^{381}$ ascendente, descendente ou irmão. Pergunta-se: nesse caso, seria possível uma pluralidade de assistentes?

PATENTE antecipa-se pela negativa, citando a regra prevista no art. 36, do Código de Processo Penal, ${ }^{382}$ que estabelece uma ordem de preferência entre os legitimados ( $1^{\circ}$ cônjuge; $2^{\circ}$ ascendentes; $3^{\circ}$ descendentes; $4^{\circ}$ irmãos), de modo que, por exemplo, se o cônjuge ${ }^{383}$ e o irmão se apresentarem, a preferência será do cônjuge. Nada impede, claro, que quem esteja abaixo da ordem de preferência seja habilitado desde que candidatos acima da referida ordem não se apresentem naquele azo processual. ${ }^{384}$

Alguns dispositivos legais conferem legitimidade a determinadas pessoas jurídicas, de caráter público ${ }^{385}$ ou privado, para atuar como assistentes em situações específicas, podendo-se citar: o art. 530-H, do Código de Processo Penal, acrescido pela Lei n. 10.695/03, que prevê que associações de titulares de direitos de autor e os que lhes são conexos poderão, em seu próprio nome, atuar como assistente nos crimes previstos no art. 184 do Código Penal, quando praticados em detrimento de qualquer de seus associados; o art. $2^{\circ}, \S 1^{\circ}$, do Decreto-Lei n. 201/67, que contempla a legitimidade de atuação para órgãos públicos lesados em crimes de responsabilidade de prefeitos; o art. 26, parágrafo único, da Lei n. 7.492/86, que prevê a legitimidade da Comissão de Valores Imobiliários e do Banco do Brasil em crimes contra o sistema financeiro praticados no âmbito do poder de fiscalização desses entes; o art. 80, da Lei n. 8.078/90 (Código de Defesa do Consumidor), que legitima entidades e órgãos da Administração Pública direta e indireta, bem como associações de proteção ao consumidor, nos crimes contra as relações

\footnotetext{
${ }^{381}$ Por força do disposto na Constituição Federal, art. 226, $\S 3^{\circ}$.

382 “Art. 36. Se comparecer mais de uma pessoa com direito de queixa, terá preferência o cônjuge, e, em seguida, o parente mais próximo na ordem de enumeração constante do art. 31, podendo, entretanto, qualquer delas prosseguir na ação, caso o querelante desista da instância ou a abandone".

${ }^{383}$ Entenda-se aqui também o convivente, por força do disposto no art. 226, §3º da Constituição Federal.

${ }^{384}$ PATENTE, Antônio Francisco. O assistente da acusação. Belo Horizonte: Del Rey, 2003, p. 42-44.

${ }^{385}$ Sobre a já superada controvérsia acerca da impossibilidade de atuação de pessoas/órgãos públicos como assistente, sob o argumento de que o interesse público já estaria representado pelo Ministério Público, cf. OLIVEIRA, Eugênio Pacelli. Curso de processo penal. 11. ed. Rio de Janeiro: Lumen Juris, 2009, p. 419 e 420.
} 
de consumo.

O Código de Processo Penal, em seu art. 270, estabelece ainda uma regra proibitiva em relação à legitimidade como assistente, vedando ao corréu a habilitação como assistente dentro do mesmo processo em que esteja sendo acusado. Referida proibição tem o objetivo de evitar a confusão no desempenho de seus respectivos papéis pelos sujeitos processuais, visto que não se poderia distinguir claramente até que ponto alguém, em tal situação, agiria no intuito de defender-se ou no intuito de colaborar efetivamente com o Ministério Público.

Para a atuação como assistente, a conjugação dos arts. 272 e 273, do Código de Processo Penal, exige um procedimento de habilitação. Apresentado o pedido pelo interessado, representado por advogado ou defensor público - ressalvando-se a possibilidade de o próprio interessado gozar de capacidade postulatória - o juiz ouvirá o Ministério Público e depois prolatará decisão, admitindo o requerente ou não como assistente, decisão sobre a qual não cabe recurso. ${ }^{386}$

A matéria objeto da análise do juiz e do Ministério Público, no procedimento de habilitação de assistente, parece cingir-se à questão da legitimidade e sua respectiva comprovação documental. Verifica-se, assim, se o requerente ostenta legitimação para a habilitação e se o comprova documentalmente. Em caso de pluralidade de requerimentos, em se tratando de legitimação supletiva, analisa-se a ordem de preferência entre os interessados. De qualquer forma, não pode ser objeto de apreciação qualquer juízo subjetivo sobre a habilitação pretendida. ${ }^{387}$

A existência desse procedimento, a nosso ver, traz vantagens para o processo e para o próprio assistente. Para o processo, porque a habilitação serve para garantir um controle específico e efetivo sobre a legitimidade do interessado e, na hipótese de titulares de legitimação supletiva, para proporcionar um controle sobre a ordem de preferência (art. 31); para o assistente, porque uma vez assim constituído, a habilitação lhe assegura a possibilidade de atuar durante todo o processo, firmando-se em seu favor uma posição estável (e não meramente eventual) de sujeito processual, no que se lhe assegura o direito

\footnotetext{
${ }^{386}$ Não obstante a inexistência de previsão legal de recurso no caso, a doutrina admite a utilização de mandado de segurança pelo interessado cujo pleito de habilitação seja indeferido: PATENTE, Antônio Francisco. O assistente da acusação. Belo Horizonte: Del Rey, 2003, p. 56; e OLIVEIRA, Eugênio Pacelli. Curso de processo penal. 11. ed. Rio de Janeiro: Lumen Juris, 2009, p. 425.

${ }^{387}$ PATENTE, Antônio Francisco. O assistente da acusação. Belo Horizonte: Del Rey, 2003, p. 54-55.
} 
de ser notificado para comparecer a todos os atos processuais. ${ }^{388}$

Observe-se que dentre as recentes alterações trazidas pela Lei n. 11.690/08 ao Código de Processo Penal, passou-se a contemplar uma hipótese de atuação processual da vítima, independentemente de sua habilitação como assistente. Trata-se do disposto na nova redação do $\S 3^{\circ}$, do art. 159 , o qual agora enuncia que "serão facultadas ao Ministério Público, ao assistente de acusação, ao ofendido, ao querelante e ao acusado a formulação de quesitos e indicação de assistente técnico". (destaques nossos).

Esse dispositivo não somente assegura ao ofendido as faculdades de formular quesitos e de indicar assistente técnico, mesmo que não esteja habilitado, como também propicia, em tese, a possibilidade de que, em crimes que apresentem vítimas diversas, a vítima-assistente e a vítima-não assistente possam exercer tais faculdades independentemente, fugindo a toda a sistemática legal então existente. ${ }^{389}$

Deve-se deixar claro que a habilitação da vítima como assistente não pode servir de condição para conferir-lhe a tutela de qualquer de seus demais direitos, a saber, o direito à proteção, o direito à informação, o direito à participação (sob as demais modalidades) e o direito à solução consensual do processo. Somente em relação ao direito de atuar em concurso (ou cooperação) com o Ministério Público é que se lhe exige, via de regra, a habilitação. Assim, por exemplo, independentemente de constituir-se ou não como assistente, a vítima tem o direito de requerer sua inclusão em programa de proteção, de requerer que seja declarado o sigilo em relação a seus dados, o direito à assistência multidisciplinar, o direito a ser cientificada sobre alguns atos processuais etc.

Quanto à oportunidade para a habilitação como assistente, conforme a inteligência dos arts. 268 e 269, somente pode ser efetuada a partir da instauração do processo, ou seja, do recebimento da denúncia, até o trânsito em julgado da sentença, recebendo a causa no estado em que se encontrar.

Não obstante a vítima possa pleitear sua habilitação durante todo o processo, fica-lhe vedada a atuação como assistente durante a fase da investigação preliminar. Nessa fase, à vítima assiste o direito de petição, em defesa de seus direitos ou contra ilegalidade ou abuso de poder (Constituição Federal, art. 5', XXXIV, “a"), contudo, não existe o

\footnotetext{
388 Nesse sentido, dispõe o Código de Processo Penal, em seu art. 399: "Recebida a denúncia ou queixa, o juiz designará dia e hora para a audiência, ordenando a intimação do acusado, de seu defensor, do Ministério Público e, se for o caso, do querelante e do assistente. (Redação dada pela Lei $\mathrm{n}^{\circ} 11.719$, de 2008)".

${ }^{389}$ O dispositivo referido, tal como se encontra, pode levar ao questionamento: caberá ao juiz, em tal hipótese, notificar também o ofendido não habilitado como assistente para apresentar seus quesitos e indicar assistente técnico? $\mathrm{Na}$ verdade, parece ter havido um equívoco do legislador, até mesmo porque a hipótese em análise não contempla nenhum motivo em especial que torne possível essa intervenção sem habilitação.
} 
dever, por parte dos órgãos responsáveis pela persecução penal (Polícia e Ministério Público), de atender aos pedidos daquela.

As disposições existentes no Código de Processo Penal a respeito mostram-se todas nesse sentido: a) a vítima pode requerer instauração de inquérito policial, pedido esse que pode ser indeferido pela autoridade policial, cabendo "recurso" ao "chefe de Polícia" (art. $5^{\circ}$, II e $\S 2^{\circ}$ ); b) a vítima (assim como o indiciado) poderá requerer qualquer diligência, que será realizada, ou não, a juízo discricionário da autoridade policial (art. 14).

Por fim, deve-se frisar que em relação ao Tribunal do Júri, a Lei agora exige uma antecedência mínima para a habilitação do assistente que deseje atuar em determinada sessão. Conforme o disposto no art. 430, do Código de Processo Penal, com a redação dada pela Lei n. 11.689/08, o assistente somente será admitido a atuar na sessão do júri se tiver requerido sua habilitação até cinco (05) dias da data da referida sessão.

\subsubsection{Atribuições}

Conforme o disposto no art. 271, do Código de Processo Penal, em sua redação original (de 1941), que ainda hoje se encontra em vigor, “ao assistente será permitido propor meios de prova, requerer perguntas às testemunhas, aditar o libelo e os articulados, participar do debate oral e arrazoar os recursos interpostos pelo Ministério Público, ou por ele próprio, nos casos dos arts. 584, § 1ํㅡ, e 598”. Alguns dispositivos legais restaram acrescidos, ampliando um pouco as faculdades de atuação processual do assistente, devendo-se realizar uma análise geral dessas atribuições.

O aditamento do libelo, originariamente previsto em 1941, já não tem mais espaço em face da reforma operada pela Lei n. 11.689/08, que baniu do ordenamento jurídico brasileiro essa peça processual.

Embora se permitisse anteriormente o aditamento do libelo, o aditamento da denúncia era e ainda é vedado ao assistente, tendo em vista considerar-se como ingerência na exclusividade da titularidade da ação penal de iniciativa pública. ${ }^{390} \mathrm{O}$ aditamento ao libelo, por sua vez, somente se justificava caso tal peça estivesse em dissonância com a pronúncia, servindo a atuação do assistente como instrumento para correção de eventual

\footnotetext{
${ }^{390}$ PATENTE, Antônio Francisco. O assistente da acusação. Belo Horizonte: Del Rey, 2003, p. 63-64.
} 
falha do Ministério Público, o que estaria dentro de seu perfil de atuação. ${ }^{391}$

No tocante ao aditamento da denúncia, chegou-se a propor que "o assistente poderá, nos casos da denúncia não ter sido oferecida contra todos os indiciados, e havendo prova da materialidade e indícios de sua autoria, supletivamente oferecer queixa-crime, com fundamento no $\$ 3^{\circ}$, do artigo 102 do CP”. ${ }^{392}$ Tratar-se-ia, no caso, de atuação supletiva do assistente em caso de arquivamento implícito. Essa questão, todavia, já parece superada na literatura jurídica e na jurisprudência, de modo a não se admitir a possibilidade de arquivamento implícito, cabendo ao juiz, caso o promotor seja omisso na acusação em relação a determinados indiciados e/ou fatos típicos, aplicar o disposto no Código de Processo Penal, art. 28. ${ }^{393}$

Estabelece o Código de 1941, também, a faculdade de o assistente propor meios de prova (art. 271, caput). Esse termo não restou empregado pelo legislador acidentalmente. Coligido tal dispositivo com seu $\S 1^{\underline{0}}$ (“O juiz, ouvido o Ministério Público, decidirá acerca da realização das provas propostas pelo assistente”), chega-se a uma inevitável conclusão: o assistente não tem direito à prova no processo penal brasileiro, limitando-se apenas a sugerir a produção de elementos de prova.

Essa sugestão dependerá do assentimento do promotor, que poderá endossá-la, surgindo, somente a partir de então, o direito à prova, sendo este conferido ao Ministério Público e não ao assistente. Nada impede que o juiz, respeitado o sistema acusatório, também possa determinar a produção de elementos de prova de ofício com base na

${ }^{391}$ FERNANDES, Antônio Scarance. O papel da vítima no processo criminal. São Paulo: Malheiros, 1995, p. 145.

${ }^{392}$ ZIYADE, Fátima. O assistente da acusação. Porto Alegre: Livraria do Advogado, 1993, p. 114.

${ }^{393}$ STF: HC 104356/RJ. Relator: RICARDO LEWANDOWSKI. Julgamento: 19.10.2010. Órgão julgador: Primeira Turma. Publicação DJe-233 DIVULG 01-12-2010 PUBLIC 02-12-2010. "HABEAS CORPUS. PROCESSUAL PENAL. ALEGAÇÃO DE ARQUIVAMENTO IMPLÍCITO. INEXISTÊNCIA DE PREVISÃO LEGAL. PACIENTE DENUNCIADO PELO CRIME DE TORTURA APENAS NA SEGUNDA DENÚNCIA. POSSIBILIDADE. INCIDÊNCIA DO PRINCÍPIO DA INDISPONIBILIDADE DA AÇ̃̃O PENAL PÚBLICA. NÃO APLICAÇÃO DO PRINCÍPIO DA INDIVISIBILIDADE NESSA HIPÓTESE. ORDEM DENEGADA. PRECEDENTES DA CORTE. I - Alegação de ocorrência de arquivamento implícito do inquérito policial, pois o Ministério Público estadual, apesar de já possuir elementos suficientes para a acusação, deixou de incluir o paciente na primeira denúncia, oferecida contra outros sete policiais civis. II - Independentemente de a identificação do paciente ter ocorrido antes ou depois da primeira denúncia, o fato é que não existe, em nosso ordenamento jurídico processual, qualquer dispositivo legal que preveja a figura do arquivamento implícito, devendo ser o pedido formulado expressamente, a teor do disposto no art. 28 do Código Processual Penal. III - Incidência do postulado da indisponibilidade da ação penal pública que decorre do elevado valor dos bens jurídicos que ela tutela. IV Não aplicação do princípio da indivisibilidade à ação penal pública. Precedentes. V - Habeas corpus denegado". (BRASIL. Supremo Tribunal Federal. Habeas Corpus n. 104356, do Superior Tribunal de Justiça. Brasília/ DF, 08.06.2010. (Disponível em: <http://www.stf.jus.br/portal/jurisprudencia/listarJurisprudencia.a sp?s1=\%22arquivamento + impl\%EDcito\%22e+Epenal\&base+baseAcordaos $>$. Acesso em 13.01.2012). No mesmo sentido, cf. OLIVEIRA, Eugênio Pacelli. Curso de processo penal. 11. ed. Rio de Janeiro: Lumen Juris, 2009, p. 57 e LOPES JÚNIOR, Aury. Direito processual penal e sua conformidade constitucional. 5. ed. rev. atual. Rio de Janeiro: Lumen Juris, 2010, v.1, p. 291. 
proposição do assistente, hipótese em que também não haverá direito de prova em prol do assistente. $^{394}$

Chegou-se a questionar na literatura jurídica se o assistente pode arrolar testemunhas. Em sentido contrário, com fundamento na ausência de direito à prova, GRECO FILHO argumenta que o assistente “[...] não pode, portanto, arrolar testemunhas, nem para completar o número legal, não só porque a oportunidade da acusação já está ultrapassada (foi na denúncia), mas também porque propor prova é diferente da faculdade das partes de arrolar testemunhas [...]".395

De fato, a ausência de direito à prova e a preclusão para arrolar as testemunhas quando do oferecimento da denúncia impõem-se como obstáculos de difícil transposição para a viabilização dessa faculdade processual para o assistente. Restam-lhe, assim, duas possibilidades residuais e bastante limitadas: indicar testemunhas para o Ministério Público antes do oferecimento da denúncia, a fim de que o órgão ministerial as arrolasse em sua cota, ou sugerir, no curso da instrução, a oitiva de testemunhas a serem creditadas no poder de instrução de ofício do juiz, o que dependeria do assentimento deste, condicionando-se ainda a evitar a violação do sistema acusatório.

Observe-se que a existência de mera faculdade de proposição de provas, e não de direito à prova, deve dar a tônica para a interpretação da nova redação conferida ao art. 402, do Código de Processo Penal ("Produzidas as provas, ao final da audiência, o Ministério Público, o querelante e o assistente e, a seguir, o acusado, poderão requerer diligências cuja necessidade se origine de circunstâncias ou fatos apurados na instrução").

Assim, ao final da instrução, ao passo que o Ministério Público, o querelante e o acusado podem requerer ao juiz a produção de elementos de prova complementares, no exercício de seu direito à prova, ao assistente faculta-se tão-somente a proposição dessa produção probatória complementar.

A participação do assistente na audiência de instrução (ou sessão do júri) é por lei assegurada, tendo, para tanto, direito a ser intimado para comparecer a tal ato. $\mathrm{Na}$ audiência, poderá formular perguntas às testemunhas arroladas pelo Ministério Público e pela defesa, bem como participar dos debates orais, garantindo-se lhe o direito de exposição de suas razões finais, conforme disposto no art. $\S 2^{\circ}$, do art. 403: "ao assistente

\footnotetext{
394 Sobre esses dispositivos legais: "Não se cuida de requerimento porque não tem o assistente, como as partes, o direito à prova. Assim, se não acolhido o pedido da vítima e a prova não for produzida, não resultará nulidade do processo". (FERNANDES, Antônio Scarance. O papel da vítima no processo criminal. São Paulo: Malheiros, 1995, p. 143).

${ }^{395}$ GRECO FILHO, Vicente. Manual de processo penal. 8. ed. São Paulo: Saraiva, 2010, p. 243-244.
} 
do Ministério Público, após a manifestação desse, serão concedidos 10 (dez) minutos, prorrogando-se por igual período o tempo de manifestação da defesa".

Quanto à matéria de recursos, o art. 271, do Código de Processo Penal faculta ao assistente "arrazoar os recursos interpostos pelo Ministério Público, ou por ele próprio, nos casos dos arts. 584, $\S 1^{\circ}$, e 598 ”, o que merece algumas considerações.

Nesse ponto, cabe destacar que se atribui ao assistente a faculdade irrestrita de arrazoar os recursos interpostos pelo Ministério Público, obedecidos, claro, os limites firmados por tal recurso, caracterizando-se aqui o caráter acessório da atuação da vítima, que somente poderá acrescer argumentos à impugnação interposta, vedando-se-lhe a alteração desse mesmo recurso, sob pena de invadir a esfera de atribuições do órgão ministerial; em contrapartida, cabe também ao assistente contra-arrazoar os recursos interpostos pela defesa.

Quanto à legitimidade do assistente para a interposição de recursos em nome próprio, ${ }^{396}$ destacam-se, para OLIVEIRA, dois requisitos: a) inércia do Ministério Público; b) natureza da decisão a ser impugnada. ${ }^{397}$

Quanto ao primeiro requisito, deve-se ressaltar que o assistente somente poderá interpor recursos se o Ministério Público não o fizer, o que leva LOPES JÚNIOR a falar em atuação recursal supletiva. ${ }^{398}$ Nada obsta que na hipótese de recurso parcial interposto pelo Ministério Público, o assistente possa recorrer em relação à parte não recorrida, uma vez obedecido o requisito supérstite. ${ }^{399}$

O segundo requisito diz respeito às hipóteses de recurso manejáveis pelo assistente, podendo esse impugnar, por apelação, as sentenças de absolvição e de impronúncia, e por recurso em sentido estrito, a sentença que declara a extinção de punibilidade. $^{400}$ Sobre tais decisões poderá também interpor embargos de declaração, bem como recursos especial e extraordinário (Súmula n. 210, do STF); registre-se ainda que, para alguns, nas hipóteses em que interpuser a apelação, se esta for denegada, o assistente

\footnotetext{
${ }^{396}$ Quando da interposição de recursos, assim como por ocasião do exercício de ação penal de iniciativa privada subsidiária, não nos parece que se trate de substituição processual, já que à vítima deve ser reconhecido interesse próprio para a prática de tais faculdades processuais.

397 OLIVEIRA, Eugênio Pacelli. Curso de processo penal. 11. ed. Rio de Janeiro: Lumen Juris, 2009, p. 422.

${ }^{398}$ LOPES JÚNIOR, Aury. Direito processual penal e sua conformidade constitucional. 5. ed. rev. atual. Rio de Janeiro: Lumen Juris, 2010, v. 2, p. 49.

399 OLIVEIRA, Eugênio Pacelli. Curso de processo penal. 11. ed. Rio de Janeiro: Lumen Juris, 2009, p. 423.

${ }^{400}$ Se a extinção de punibilidade for declarada em sentença de absolvição sumária, o recurso cabível e manejável pelo assistente será a apelação, por força do disposto no Código de Processo Penal, art. 397, IV c/c art. 593, I.
} 
poderá interpor recurso em sentido estrito com fulcro no Código de Processo Penal, art. $581, \mathrm{XV}^{401}$

O prazo para a atuação recursal supletiva do assistente, conforme o disposto na Súmula n. 448, do STF, começa a correr imediatamente a partir do trânsito em julgado da sentença para o Ministério Público, ou seja, a partir da configuração da inércia ministerial. Sobre o tema, faz-se mister recordar as explanações anteriormente tecidas sobre o direito à informação, mais especificamente sobre o direito da vítima, habilitada ou não nos autos como assistente, de ser intimada da sentença. ${ }^{402}$

Além das atribuições até aqui comentadas, outras atribuições foram trazidas por legislação processual esparsa em favor do assistente, ampliando-se um pouco mais o rol de suas faculdades processuais. Assim, a Lei n. 11.689/08 deu nova redação ao art. 427, do Código de Processo Penal, passando a prever a possibilidade de o assistente requerer o desaforamento em processos do júri junto ao Tribunal; ${ }^{403}$ a Lei n. 11.690/08, modificando a redação do $\$ 3^{\circ}$, do art. 159 , do Código de Processo Penal, passou a facultar ao assistente a formulação de quesitos e a indicação de assistente técnico em prova pericial; ${ }^{404}$ por fim, a Lei n. 12.403/11, reformulando a redação do art. 311 , e do $\$ 4^{\circ}$, do art. 282, do Código de Processo Penal, passou a contemplar a faculdade de o assistente, em caso de descumprimento, requerer a substituição da medida cautelar determinada, sua cumulação com outra medida ou, em último caso, a decretação da prisão preventiva, ${ }^{405}$ bem como a faculdade de o assistente requerer a prisão preventiva em qualquer fase da investigação policial ou do processo penal. ${ }^{406}$

\footnotetext{
401 "Admite-se, ainda, interposição de recurso em sentido estrito com fundamento no inc. XV, quando o juiz não receba a apelação do ofendido ou venha a julgá-la deserta, pois não teria sentido que pudesse apelar (art. 598) e não lhe fosse garantido o direito de recorrer contra a decisão que não admitisse a sua impugnação." (GRINOVER, Ada Pellegrini; GOMES FILHO, Antônio Magalhães; FERNANDES, Antônio Scarance. Recursos no processo penal: teoria geral dos recursos, recursos em espécie, ações de impugnação, reclamação aos tribunais. 6. ed. ver. atualiz. e ampl. São Paulo: Revista dos Tribunais, 2009, p. 141-142). ${ }^{402}$ Cf. item 3.3.2.

403 “Art. 427. Se o interesse da ordem pública o reclamar ou houver dúvida sobre a imparcialidade do júri ou a segurança pessoal do acusado, o Tribunal, a requerimento do Ministério Público, do assistente, do querelante ou do acusado ou mediante representação do juiz competente, poderá determinar o desaforamento do julgamento para outra comarca da mesma região, onde não existam aqueles motivos, preferindo-se as mais próximas".

404 " $\S 3^{\circ}$ Serão facultadas ao Ministério Público, ao assistente de acusação, ao ofendido, ao querelante e ao acusado a formulação de quesitos e indicação de assistente técnico." (destaques nossos).

${ }^{405}$ Art. 282, § 4 " "No caso de descumprimento de qualquer das obrigações impostas, o juiz, de ofício ou mediante requerimento do Ministério Público, de seu assistente ou do querelante, poderá substituir a medida, impor outra em cumulação, ou, em último caso, decretar a prisão preventiva (art. 312, parágrafo único)." (destaque nosso).

406 "Art. 311. Em qualquer fase da investigação policial ou do processo penal, caberá a prisão preventiva decretada pelo juiz, de ofício, se no curso da ação penal, ou a requerimento do Ministério Público, do querelante ou do assistente, ou por representação da autoridade policial.” (destaque nosso).
} 


\subsection{NOVAS PERSPECTIVAS PARA O ASSISTENTE}

O instituto da assistência no processo penal, tal qual hoje encontra conformidade no ordenamento jurídico brasileiro, parece ter ficado a meio caminho em relação às exigências do movimento vitimológico. De fato, por um lado, busca evitar o completo alijamento processual da vítima, entretanto, por outro, assegura à vítima uma participação secundária e supletiva, dispensando-lhe o status de um sujeito processual de categoria inferior.

O respeito à dignidade da vítima impõe mais do que isso, fazendo-se necessária uma verdadeira redefinição processual do assistente, de modo a garantir-lhe uma atuação processual mais efetiva, compatível com a condição de coprotagonista do processo penal.

Para se esboçar uma proposição dessa redefinição do instituto e a respectiva remodelação de suas atribuições, sugere-se aqui uma prévia análise sobre essa modalidade de participação da vítima no direito comparado e junto a órgãos jurisdicionais internacionais, que, embora aqui realizada em caráter simplificado, se mostrará bastante aos fins do presente estudo.

\subsubsection{Perspectivas de direito comparado e dos órgãos internacionais}

\subsubsection{Alemanha}

Na Alemanha, o Estado detém o monopólio da acusação, previsto no §152 e 1, combinado com o $\$ 170$ e 1, do StPO, que é atribuído ao Ministério Público, sendo o princípio da legalidade (obrigatoriedade) a complementação necessária desse monopólio. $^{407}$

${ }^{407}$ Cf. TIEDEMANN, em: ROXIN, Claus; ARZT, Gunther; TIEDEMANN, Klaus; Introdução ao direito penal e ao direito processual penal. Tradução de Gercélia Batista de Oliveira Mendes. Belo Horizonte: Del Rey, 2007, p. 194. 
Como exceção ao monopólio estatal da acusação e ao princípio da legalidade, surge a ação penal privada (Privatklage), em que a própria vítima pode requerer a instauração do processo penal independentemente de anuência ou atuação do Ministério Público. Em tal procedimento, a vítima, ressalvadas suas limitações, faz as vezes do Ministério Público, sendo-lhe assegurados processualmente, em boa medida, os direitos desse órgão estatal $(\$ 385,1$, StPO).

Convém distinguir os crimes que ensejam ação penal privada dos crimes que dependem de Strafantrag (os Antragsdelikte), instituto que equivale à ação penal de iniciativa pública condicionada à representação do ofendido, do direito brasileiro. Nos delitos sujeitos ao aludido instituto alemão, a justiça penal somente poderá atuar após manifestação inequívoca e formal da vítima, a qual deve ser formulada por escrito e apresentada dentro de três (03) meses, a contar do conhecimento do fato e da autoria. ${ }^{408}$

As hipóteses de ação penal privada são bastante escassas, resumindo-se a um pequeno número de infrações de pouca gravidade, como injúria, violação de domicílio, violação do sigilo de correspondência e lesão corporal (\$374, 3, StPO), hipóteses essas que muitas vezes coincidem com os Antragsdelikte. ${ }^{409}$

Impende registrar que mesmo em se tratando de Privatklage, caso o Ministério Público vislumbre a existência de interesse público, poderá ajuizar a ação penal pública, como também encampar a ação privada já iniciada, ${ }^{410}$ cabendo à vitima a possibilidade de continuar vinculada ao processo na condição de Nebenkläger.

A Nebenklage ( $\$ 395$ a 402, StPO) consiste na atuação colaborativa da vítima

\footnotetext{
${ }^{408}$ Cf. ESER, Albin. Acerca del renacimiento de la víctima en el procedimiento penal: tendencias nacionales e internacionales. Tradução de Fabrício O. Guariglia e Fernando J. Córdoba. In: MAIER, Julio B. J. (Comp.). De los delitos y de las víctimas. Buenos Aires: Ad Hoc, 2001, p. 13-52, p. 19-20.

409 “Crimes de ação penal privada são, sobretudo, aqueles relacionados com a pessoa, como injúria, atentado contra a paz doméstica, violação do sigilo de correspondência. Muitas vezes - porém não necessariamente são idênticos aos crimes de ação penal pública condicionada (Antragsdelikte) nos quais a persecução penal depende de uma representação (Strafantrag) do ofendido (c $f$. $\S 158,2^{\circ}$, do CPP alemão). Exemplo de crime de ação penal pública condicionada que não é crime de ação privada, mas crimes de ação penal pública (Offizialdelikt) o furto domiciliar e familiar (\$247 do CP alemão).” (destaques do autor). (ROXIN, Claus; ARZT, Gunther; TIEDEMANN, Klaus; Introdução ao direito penal e ao direito processual penal. Tradução de Gercélia Batista de Oliveira Mendes. Belo Horizonte: Del Rey, 2007, p. 202).

410 "Por cierto, en los delitos de acción privada una acusación pública (a través del ministerio público) se encuentra, en principio, excluida; sin embargo, ella continúa siendo permitida cuando la acusación del fiscal se base en un 'interés público' (\$376, OPP): así sucede en aquelles casos donde, más allá de la esfera de damnificados directos, la praz jurídica general es alterada, como por ejemplo, en la injuria dirigida a un círculo amplio de personas, o por motivos racistas. En tal caso, el ministerio público puede desde un principio instar la acción penal pública, como asi también tomar en sus manos um procedimiento de acción privada ya iniciado (\$377, OPP).”: ESER, Albin. Acerca del renacimiento de la víctima en el procedimiento penal: tendencias nacionales e internacionales. Tradução de Fabrício O. Guariglia e Fernando J. Córdoba. In: MAIER, Julio B. J. (Comp.). De los delitos y de las víctimas. Buenos Aires: Ad Hoc, 2001. p. 13-52, p. 2122.
} 
em sede de ação penal pública, assemelhando-se, a princípio, resguardadas as devidas peculiaridades, à assistência prevista no processo penal brasileiro.

Não se deve confundir a Nebenklage com o processo de adesão (Adhäsionsverfahren). Segundo CÂMARA, a primeira consiste na adesão de uma pessoa privada a uma demanda pública intentada pelo Ministério Público, de caráter acessório, visto que dependente de ajuizamento da ação pelo Estado, ao passo que o segundo trata-se de procedimento que cuida da reparação das vítimas de delito, em que estas se valem de sua pretensão civil no próprio processo penal (reparação endoprocessual). ${ }^{411}$

O Nebenkläger pode agir sob dois propósitos: o de colaborar com a atuação acusatória estatal desenvolvida pelo Ministério Público, bem como o de reunir elementos probatórios para o posterior ajuizamento de ação civil, sem precisar suportar excessivos encargos financeiros. ${ }^{412}$

A legitimidade para habilitar-se como Nebenkläger, antes restrita aos legitimados para a proposição de ação privada, restou ampliada após a Lei de Proteção das Vítimas, de $1986 .{ }^{413}$

Segundo ESER, gozam de legitimidade para tanto: a) as vítimas das infrações constantes no $\$ 395$, 1, números 1 e 2, StPO (particularmente, tentativa de homicídio, lesões corporais, infrações relacionadas à dignidade sexual, infrações graves contra a propriedade etc.); b) parentes próximos das vítimas de homicídio; c) a vítima que se valer do procedimento de provocação da ação penal pública; d) em caso de difamação de certos órgãos constitucionais, confere-se legitimidade ao particular ofendido. ${ }^{414}$

Para habilitar-se, a vítima deve apresentar uma declaração escrita, em que manifeste a intenção de ingressar no processo instaurado a partir de ação pública, incumbindo ao Tribunal, uma vez ouvido o Ministério Público, decidir sobre sua admissão,

\footnotetext{
${ }^{411}$ CÂMARA, Guilherme Costa. Programa de política criminal orientado para a vítima do crime. São Paulo: Editora Revista dos Tribunais; Coimbra: Coimbra Editora, 2008, p. 316.

${ }^{412}$ ESER destaca a melhor situação de que o Nebenkläger goza em relação ao autor da ação privada, já que aquele somente precisa suportar seus próprios gastos. As custas do procedimento e os encargos referentes à absolvição do acusado são suportados apenas pelo Estado. (ESER, Albin. Acerca del renacimiento de la víctima en el procedimiento penal: tendencias nacionales e internacionales. Tradução de Fabrício $\mathrm{O}$. Guariglia e Fernando J. Córdoba. In: MAIER, Julio B. J. (Comp.). De los delitos y de las víctimas. Buenos Aires: Ad Hoc, 2001, p. 13-52, p. 25).

${ }^{413}$ Cf. nota 857 em: CÂMARA, Guilherme Costa. Programa de política criminal orientado para a vítima do crime. São Paulo: Editora Revista dos Tribunais; Coimbra: Coimbra Editora, 2008, p. 316.

${ }^{414}$ ESER, Albin. Acerca del renacimiento de la víctima en el procedimiento penal: tendencias nacionales e internacionales. Tradução de Fabrício O. Guariglia e Fernando J. Córdoba. In: MAIER, Julio B. J. (Comp.). De los delitos y de las víctimas. Buenos Aires: Ad Hoc, 2001, p. 13-52, p. 24.
} 
de cuja decisão denegatória cabe recurso. ${ }^{415}$

Recorda CÂMARA que o instituto sob comento não se cuida de uma espécie de ação, mas de uma modalidade de intervenção do ofendido, ${ }^{416}$ afinal a ação é exercida pelo Ministério Público. Consoante ainda o mencionado autor, o Nebenkläger ostenta a qualidade de sujeito processual, ante a ampla gama de faculdades processuais de que dispõe: direito de fazer-se presente durante a audiência, direito de ser ouvido, direito de recusar juízes e peritos, direito de acesso aos autos por seu procurador, direito autônomo de requerer e apresentar elementos de prova, direito à assistência judiciária gratuita, direito autônomo de recorrer etc.. ${ }^{417}$

\subsubsection{Itália}

Embora o Codice di Procedura Penale, ou simplesmente c.p.p., não contemple a possibilidade de ação penal de iniciativa privada, ${ }^{418}$ pode-se dizer que referido diploma legal traz uma rica previsão de institutos e direitos atinentes à vítima da infração penal.

Cumpre destacar que no Código de 1930, a vítima apresentava um caráter híbrido: além de testemunha essencial, poderia constituir-se como parte civil (parte civile), que assumia uma conotação acentuadamente penalística.

No atual Código de 1988, o panorama mudou. A vítima da infração penal (persona offesa dal reato) passou a contar com diversos direitos, concentrados principalmente na fase das indagini preliminari, ao passo que, uma vez exercida a ação penal, confere-se à vítima, se também titular de danos patrimonais, a possibilidade de

\footnotetext{
${ }^{415}$ ESER, Albin. Acerca del renacimiento de la víctima en el procedimiento penal: tendencias nacionales e internacionales. Tradução de Fabrício O. Guariglia e Fernando J. Córdoba. In: MAIER, Julio B. J. (Comp.). De los delitos y de las víctimas. Buenos Aires: Ad Hoc, 2001, p. 13-52, p. 25.

${ }^{416}$ CÂMARA, Guilherme Costa. Programa de política criminal orientado para a vítima do crime. São Paulo: Editora Revista dos Tribunais; Coimbra: Coimbra Editora, 2008, p. 316.

${ }^{417}$ CÂMARA, Guilherme Costa. Programa de política criminal orientado para a vítima do crime. São Paulo: Editora Revista dos Tribunais; Coimbra: Coimbra Editora, 2008, p. 317-318.

${ }^{418}$ Para algumas infrações, a lei exige a apresentação de querela, instituto semelhante à representação nas ações penais de iniciativa pública condicionada do direito processual penal brasileiro. Quanto a tal querela, cabe destacar sua importância e a discricionariedade da vítima em seu exercício: "Formalmente costruita come atto che toglie un ostaculo all'esercizio dell'azione penale, la querela ha in concreto in considerevole peso. In fato, quando il soggetto titolare del diritto di querela scelga di non avvalersene, questa opzione blocca in modo necessario e definitivo l'azione penale, il cui 'non esercizio' viene dunque lasciato alla discrezionalità dell'offeso". (AIMONETTO, Maria Gabriella. Azione penale e ruolo della vittima in Italia e Francia. L'indice Penale, Padova, v. 29, n. 1, p.185-211, genn./apr. 1995, p. 193-194).
} 
constituição em parte civil, instituto agora adstrito aos interesses cíveis. ${ }^{419}$

Para se tentar buscar uma identificação aproximada da figura do assistente no processo penal brasileiro a eventual figura correlata no Direito italiano, deve-se, primeiramente, descartar a figura da parte civile, já que inexistente no ordenamento jurídico nacional. ${ }^{420}$

A identificação aludida, assim, parece recair na figura da persona offesa dal reato, mais especificamente em sua atuação após a instauração do processo penal, ou seja, após o ajuizamento da ação penal pelo Ministério Público (Pubblico Ministero), ${ }^{421}$ já que no direito brasileiro não existe habilitação de assistente na investigação preliminar.

Uma vez exercida a ação penal, restam à persona offfesa dal reato os direitos previstos no art. 90, 1, do c.p.p., ${ }^{422}$ a saber, a apresentação de razões escritas e a indicação de elementos de prova.

Tais direitos levam a literatura jurídica a atribuir à persona offesa uma função de acusação privada, sobre cuja natureza não se encontra unanimidade, podendo ser definida como subsidiária, adesiva ou complementar. ${ }^{423}$

De qualquer forma, para AIMONETTO, não se deve esquecer que a função da vítima durante o processo é meramente de postulante, pois não tem direito à prova, não pode participar dos debates finais nem tampouco impugnar decisões. ${ }^{424}$

Quanto a esta última situação, a vítima possui apenas a faculdade de solicitar ao Pubblico Ministero que este ofereça impugnação às decisões judiciais, tendo direito, em caso negativo, a uma resposta fundamentada (artigos 572,1 e 2, do c.p.p.). ${ }^{425}$

\footnotetext{
${ }^{419}$ AIMONETTO, Maria Gabriella. Azione penale e ruolo della vittima in Italia e Francia. L'indice Penale, Padova, v. 29, n. 1, p.185-211, genn./apr. 1995, p. 201.

${ }^{420}$ Equiparar-se-ia a parte civile ao autor da adesão civil, tal qual prevista no Código projetado.

${ }^{421}$ A persona offesa dal reato, durante as investigações preliminares, tem atribuições muito relevantes, como a provocação da avocação das investigações pelo procurador-geral, a apresentação de razões em caso de pedido de prorrogação de investigações e o controle sobre o arquivamento das indagini preliminari - todas referentes à modalidade de controle sobre a acusação pública, já analisada neste trabalho -, sem prejuízo das atribuições previstas no art. 91, c.p.p.

${ }^{422}$ Que segue ipsis litteris: "La persona offesa dal reato, oltre ad esercitare i diritti e le facoltà ad essa espressamente riconosciuti dalla legge, in ogni stato e grado del procedimento può presentare memorie e, con esclusione del giudizio di cassazione, indicare elementi di prova." Ressalte-se que tais direitos são conferidos à vítima não somente durante o processo propriamente dito, mas já, também, nas investigações preliminares (indagini preliminari). Cf: ITÁLIA. Codice di procedura penale. Disponível em: $<$ http://www.altalex.com/index.php?idnot=2011 $>$. Acesso em: 09 jun. 2011.

${ }^{423}$ AIMONETTO, Maria Gabriella. Azione penale e ruolo della vittima in Italia e Francia. L'indice Penale, Padova, v. 29, n. 1, p.185-211, genn./apr. 1995, p. 201.

${ }^{424}$ AIMONETTO, Maria Gabriella. Azione penale e ruolo della vittima in Italia e Francia. L'indice Penale, Padova, v. 29, n. 1, p.185-211, genn./apr. 1995, p. 201-202.

425 "1. La parte civile, la persona offesa, anche se non costituita parte civile, e gli enti e le associazioni intervenuti a norma degli articoli 93 e 94, possono presentare richiesta motivata al pubblico ministero di
} 
$\mathrm{Na}$ verdade, caso a vítima não se constitua como parte civil, ${ }^{426}$ segundo AIMONETTO, resta-lhe uma atuação processual marginal. ${ }^{427}$ Sob esse ponto de vista, o arsenal de atribuições do assistente, constante no processo penal brasileiro, ainda se mostra bem superior às parcas atribuições conferidas à persona offesa dal reato do processo penal italiano. $^{428}$

\subsubsection{Portugal}

Estabelece a Constituição da República Portuguesa, em seu art. 32, $7^{429}$, que "o ofendido tem o direito de intervir no processo, nos termos da lei”. Em razão de tal dispositivo, refere-se a existência de um direito fundamental do ofendido à intervenção processual no ordenamento jurídico-constitucional português. ${ }^{430}$

Como se vê, o dispositivo constitucional utiliza-se do termo ofendido, que corresponde, no direito brasileiro, a termo homônimo, distinguindo-se ainda os termos assistente e lesado. E é a própria lei que se adianta a estabelecer tais definições.

Assim, por ofendido, entenda-se o titular dos interesses que a lei especialmente quis proteger com a incriminação (art. 86, 1, “a”, do Código de Processo Penal português, ou simplesmente CPPP); a definição de lesado corresponde à de pessoa que sofreu danos

proporre impugnazione a ogni effetto penale. 2. Il pubblico ministero, quando non propone impugnazione, provvede con decreto motivato da notificare al richiedente.".

426 Para tanto precisa ter sofrido prejuízo de ordem civil, necessitando ainda habilitar-se no processo como parte civile.

427 "Dunque, se l'offeso può - essendo al contempo daneggiato - e vuole costituirsi parte civile, egli acquisita la veste di parte e i poteri correlati. Viceversa, se intende conservar ela sola qualifica di offeso, egli resta ai margini del processo.[...]". (AIMONETTO, Maria Gabriella. Azione penale e ruolo della vittima in Italia e Francia. L'indice Penale, Padova, v. 29, n. 1, p.185-211, genn./apr. 1995, p. 205-206).

${ }^{428}$ As vantagens em prol da vítima, constantes no processo penal italiano, comparando-se com o processo penal brasileiro, consistem na existência da parte civile e na ênfase dada pelo c.p.p. à ampla possibilidade de controle sobre a acusação pública durante as indagini peliminari.

${ }^{429}$ Em decorrência de Revisão constitucional (Lei n. 1/97).

${ }^{430}$ Para CÂMARA, “[...] decerto que para além de ter passado a gozar a partir da introdução do mencionado dispositivo do requinte da tutela constitucional, conferiu-se à vítima de crime - mercê introdução do normativo em realce no catálogo dos direitos, liberdades e garantias pessoais - um direito especial, ou melhor, um direito-garantia, na realidade, verdadeiro direito fundamental procedimental de, nos termos da lei, intervir no processo." (destaques do autor). (CÂMARA, Guilherme Costa. Programa de política criminal orientado para a vítima do crime. São Paulo: Editora Revista dos Tribunais; Coimbra: Coimbra Editora, 2008, p. 276). O próprio CÂMARA esclarece que a liberdade conferida pela Constituição ao legislador ordinário não é ilimitada, devendo ser respeitado o conteúdo principal do aludido direito, o que impediria a leitura do dispositivo como se se tratasse de uma simples norma programática ou proclamatória. (CÂMARA, Guilherme Costa. Programa de política criminal orientado para a vítima do crime. São Paulo: Editora Revista dos Tribunais; Coimbra: Coimbra Editora, 2008, p. 276-278). 
ocasionados pelo crime, ainda que se não tenha constituído ou não possa constituir-se assistente (art. 74, 1, do CPPP); quanto a assistente, trata-se, via de regra, do ofendido habilitado no processo como tal.

A análise de tais conceitos levava a uma terrível constatação: o ofendido que não se constituísse assistente não gozava dos direitos desse, sendo relegado a um estado de desproteção jurídico-processual. Somente a partir da reforma de 2007, encetada pela Lei n. 48/2007, de 29 de agosto, a qual tinha por finalidade adaptar a legislação processual penal portuguesa à Decisão-Quadro/01 da União Europeia, de 15 de março - que passou a instituir um estatuto da vítima em processo penal no plano continental - é que se estabeleceu uma maior proteção para o ofendido, conferindo-lhe maior respeito à sua dignidade no âmbito do processo. ${ }^{431}$

Assim, pode-se citar, a título de exemplos: direito de requerer segredo de justiça (art. 86, 2, do CPPP); ${ }^{432}$ direito de consulta aos autos do inquérito e de extrair cópias e certidões (art. 89, 1, do CPPP); ${ }^{433}$ direito, em caso de perigo, de ser informado da libertação do arguido preso preventivamente e do preso condenado, bem como da fuga

\footnotetext{
431 “[...] quando por circunstâncias várias, o ofendido não tiver podido ou querido constituir-se assistente, não lhe assistem aqueles direitos." (SANTOS. Cláudia Cruz. A "redescoberta" da vítima e o direito processual penal português. In: ANDRADE, Manuel da Costa Andrade; ANTUNES, Maria João; SOUSA; Susana Aires de. (Org.). Estudos em homenagem ao prof. doutor Jorge de Figueiredo Dias. Coimbra: Coimbra Editora, 2010. v. 3. p. 1133-1153, p. 1138-1139); “A vítima só se torna actor processual se se constituir assistente. De outro modo, o seu papel apaga-se. Resta-lhe apenas o direito a ser informada sobre a possibilidade de pedir uma indemnização, como parte civil, de ser informada sobre a decisão do MP de arquivar o processo." (ALMEIDA, Maria Rosa Crucho de. As relações entre vítimas e sistema de justiça criminal em Portugal. Revista Portuguesa de Ciência Criminal, Coimbra, v. 3, n. 1, p. 103-116, jan./mar. 1993, p. 115); "Pode ser afirmado que o assistente é a veste obrigatória para que a vítima intervenha no processo penal, ressalvadas as hipóteses de ela figurar como parte civil ou apenas como testemunha." (FERNANDES, Fernando. O processo penal como instrumento de política criminal. Coimbra: Almedina, 2008. (Coleção teses), p. 547); “[...] é sobre as vestes de assistente que a vítima assume o papel de sujeito processual, desse modo abandonando a condição de mero auxiliar." (CÂMARA, Guilherme Costa. Programa de política criminal orientado para a vítima do crime. São Paulo: Editora Revista dos Tribunais; Coimbra: Coimbra Editora, 2008, p. 280). Não obstante os avanços, SANTOS tece críticas à reforma, aduzindo que esta traz algumas novidades pontuais, "que não significam qualquer mudança estrutural victim-oriented". (SANTOS. Cláudia Cruz. A "redescoberta" da vítima e o direito processual penal português. In: ANDRADE, Manuel da Costa Andrade; ANTUNES, Maria João; SOUSA; Susana Aires de. (Org.). Estudos em homenagem ao prof. doutor Jorge de Figueiredo Dias. Coimbra: Coimbra Editora, 2010. v. 3. p. 1133-1153, p. 1142).

432 "O juiz de instrução pode, mediante requerimento do arguido, do assistente ou do ofendido e ouvido o Ministério Público, determinar, por despacho irrecorrível, a sujeição do processo, durante a fase de inquérito, a segredo de justiça, quando entenda que a publicidade prejudica os direitos daqueles sujeitos ou participantes processuais."

433 "Durante o inquérito, o arguido, o assistente, o ofendido, o lesado e o responsável civil podem consultar, mediante requerimento, o processo ou elementos dele constantes, bem como obter os correspondentes extractos, cópias ou certidões, salvo quando, tratando- -se de processo que se encontre em segredo de justiça, o Ministério Público a isso se opuser por considerar, fundamentadamente, que pode prejudicar a investigação ou os direitos dos participantes processuais ou das vítimas."
} 
deste (arts. 217,3, 480, 3, e 482, 2, do CPPP); ${ }^{434}$ direito de ser informado acerca da notícia do crime (art. 247, 1, do CPPP); ${ }^{435}$ direito de anuência em caso de procedimentos de interceptação e de escuta (art. 187, 4, c, do CPPP). ${ }^{436}$

Todavia, não obstante essas reformas operadas em 2007, a lógica do tudo ou $n a d a$, em relação à dicotomia ofendido-assistente, apontada por ALMEIDA, ${ }^{437}$ ainda parece persistir. De fato, somente a partir da investidura processual como assistente é que se abrem efetivamente as portas do processo penal às vítimas de delito.

A assistência, cuja origem parece relacionar-se com uma desconfiança em relação à atuação do Ministério Público, ${ }^{438}$ confere aos ofendidos, nos termos do art. 69, 1 , do CPPP, “a posição de colaboradores do Ministério Público, a cuja actividade subordinam a sua intervenção no processo, salvas as excepções da lei”.

Contudo, as ideias de colaboração e de subordinação, que aparentam denotar uma atuação secundária do assistente, talvez não sejam de todo adequadas ao notável status processual que este adquire no processo penal português, ${ }^{439}$ o qual serve mesmo de inspiração para outros legisladores, marcando a proeminência do ordenamento jurídico

\footnotetext{
434 "Quando considerar que a libertação do arguido pode criar perigo para o ofendido, o tribunal informa-o, oficiosamente ou a requerimento do Ministério Público, da data em que a libertação terá lugar."; "Quando considerar que a libertação do preso pode criar perigo para o ofendido, o tribunal, oficiosamente ou a requerimento do Ministério Público, informa-o da data em que a libertação terá lugar"; "O Ministério Público comunica a fuga do preso ao tribunal, que, se considerar que dela pode resultar perigo para o ofendido, o informa da ocorrência."

435 "O Ministério Público informa o ofendido da notícia do crime, sempre que tenha razões para crer que ele não a conhece."

436 "A intercepção e a gravação previstas nos números anteriores só podem ser autorizadas, independentemente da titularidade do meio de comunicação utilizado, contra: $a$ ) Suspeito ou arguido; $b$ ) Pessoa que sirva de intermediário, relativamente à qual haja fundadas razões para crer que recebe ou transmite mensagens destinadas ou provenientes de suspeito ou arguido; ou $c$ ) Vítima de crime, mediante o respectivo consentimento, efectivo ou presumido."

437 "Entre nós, a posição da vítima no processo penal obedece a uma lógica que se pode designar, de uma forma um tanto caricatural, do tudo ou nada." (ALMEIDA, Maria Rosa Crucho de. As relações entre vítimas e sistema de justiça criminal em Portugal. Revista Portuguesa de Ciência Criminal, Coimbra, v. 3, n. 1, p. 103-116, jan./mar. 1993, p. 114-115).

438 "Historicamente, a figura do assistente visou sobretudo promover interesses processuais. Confiou-se na faculdade de iniciativa da vítima para melhorar o desempenho do MP. Hoje em dia num clima ideológico diferente, este dispositivo jurídico pode ser reconvertido e legitimado em nome da vítima, como um modo de lhe dar projecção, de não deixar que ela seja a $<<$ pessoa esquecida $>>$ do sistema de justiça criminal." (ALMEIDA, Maria Rosa Crucho de. As relações entre vítimas e sistema de justiça criminal em Portugal. Revista Portuguesa de Ciência Criminal, Coimbra, v. 3, n. 1, p. 103-116, jan./mar. 1993, p.115).

439 "[...] a locução colaboração subordinada concorre para transmitir, e a nosso pensar, de modo desnecessário, uma idéia de submissão, de subjugação, não condizente com uma personagem processual com aptidão para co-determinar, 'dentro de certos limites e circunstâncias, a decisão final do processo'. É dizer, o assistente pode atuar decisivamente para o desate processual, seja mercê ativação do controle excêntrico da atividade ministerial, seja, ainda que de modo indireto ou reflexo, pelo pressuposto de concordância concorrente e expressa do assistente, com vistas à suspensão provisória do processo. Então, pode, episodicamente gozar de uma certa autonomia, o que não afasta sua usual condição de colaborador. [...] (destaques do autor). (CÂMARA, Guilherme Costa. Programa de política criminal orientado para a vítima do crime. São Paulo: Editora Revista dos Tribunais; Coimbra: Coimbra Editora, 2008, p. 292-293).
} 
português em relação à proteção da vítima, no âmbito europeu. ${ }^{440}$

Como já se afirmou, cabe somente ao ofendido, considerado como tal o titular dos interesses protegidos pela norma incriminadora, habilitar-se como assistente, em procedimento específico para tal fim, regulado no art. 68, do CPPP. Entretanto, deve-se ressaltar a legitimidade de pessoas e entidades para habilitação como assistente, conforme disponham leis especiais, e de qualquer do povo, nos crimes contra a paz e a humanidade, bem como nos crimes de tráfico de influência, favorecimento pessoal praticado por funcionário, denegação de justiça, prevaricação, corrupção, peculato, participação econômica em negócio, abuso de poder e de fraude na obtenção ou desvio de subsídio ou subvenção (art. 68, 1, do CPPP). ${ }^{441}$

As atribuições conferidas ao assistente pelo art. 69, 2, do CPPP, comprovam seu referido status de verdadeiro sujeito processual $^{442}$ : a) intervenção no inquérito e na instrução, oferecendo provas e requerendo as diligências que se afigurarem necessárias; b)

\footnotetext{
440 "É de resto, a esta possibilidade de constituição como assistente que se atribui relevo logo na Exposição constante do Decreto-Lei $\mathrm{n}^{\circ} 78 / 87$, de 17 de Fevereiro: 'paradigmático a este respeito é o que se passa com o estatuto da vítima-assistente, que nos singulariza claramente no contexto do direito comparado e por cujo modelo começam agora a orientar-se os movimento de reforma de muitos países, sob o impulso das mais recentes investigações criminológico-vitimológicas'. Em sentido muito próximo, Jorge de FIGUEIREDO DIAS e ANABELA MIRANDA RODRIGUES sublinham que essa 'novidade' que é o reconhecimento da necessidade de proteção daquela vítima concreta 'é muito maior para a generalidade dos países europeus sobretudo do centro e do norte da Europa - do que para um país como Portugal, que desde há muito concede à vítima a maior proteção possível, que é a de lhe outorgar voz autónoma logo ao nível do processo penal na veste, desconhecida da prática totalidade das legislações europeias, de assistente." (SANTOS. Cláudia Cruz. A "redescoberta" da vítima e o direito processual penal português. In: ANDRADE, Manuel da Costa Andrade; ANTUNES, Maria João; SOUSA; Susana Aires de. (Org.). Estudos em homenagem ao prof. doutor Jorge de Figueiredo Dias. Coimbra: Coimbra Editora, 2010. v. 3. p. 1133-1153, p. 1138).

441 "Podem constituir-se assistentes no processo penal, além das pessoas e entidades a quem leis especiais conferirem esse direito: a) Os ofendidos, considerando-se como tais os titulares dos interesses que a lei especialmente quis proteger com a incriminação, desde que maiores de 16 anos; $b$ ) As pessoas de cuja queixa ou acusação particular depender o procedimento; $c$ ) No caso de o ofendido morrer sem ter renunciado à queixa, o cônjuge sobrevivo não separado judicialmente de pessoas e bens ou a pessoa, de outro ou do mesmo sexo, que com o ofendido vivesse em condições análogas às dos cônjuges, os descendentes e adoptados, ascendentes e adoptantes, ou, na falta deles, irmãos e seus descendentes, salvo se alguma destas pessoas houver comparticipado no crime; $d$ ) No caso de o ofendido ser menor de 16 anos ou por outro motivo incapaz, o representante legal e, na sua falta, as pessoas indicadas na alínea anterior, segundo a ordem aí referida, salvo se alguma delas houver comparticipado no crime; $e$ ) Qualquer pessoa nos crimes contra a paz e a humanidade, bem como nos crimes de tráfico de influência, favorecimento pessoal praticado por funcionário, denegação de justiça, prevaricação, corrupção, peculato, participação económica em negócio, abuso de poder e de fraude na obtenção ou desvio de subsídio ou subvenção."

${ }^{442}$ Não obstante o assistente ter assegurada sua condição de sujeito processual, não se deve perder de vista que sua posição se mostra inferior a dos demais sujeitos processuais: "[...] sendo considerado sujeito processual, o assistente não goza de um estatuto processual idêntico ao dos restantes sujeitos processuais (MP e arguido), desde logo porque não se trata de um sujeito processual 'necessário'. Mesmo quando validamente constituído como tal, o assistente não goza, em termos de estatuto processual, de uma mesma parificação com os outros sujeitos processuais - assim bastará a consideração das diferentes consequências processuais quanto ao seu não comparecimento a julgamento ou à sanção da ausência de notificação para comparência a actos processuais." (CUNHA, Damião da. A participação dos particulares no exercício da acção penal: alguns aspectos. Revista Portuguesa de Ciência Criminal, Coimbra, v. 8, n. 4, p.593-660, out./dez.1998, p. 629 ).
} 
dedução de acusação independente da efetuada pelo Ministério Público e, no caso de procedimento dependente de acusação particular, ainda que aquele a não deduza; c) interposição de recurso das decisões que o afete, mesmo que o Ministério Público não o tenha feito.

Outro aspecto a ser destacado consiste na possibilidade, em razão da reforma de 2007, de a suspensão provisória do processo (artigos 281 a 282, do CPPP) ${ }^{443}$ necessitar agora da anuência do assistente, ${ }^{444}$ de modo que este "pode lograr, através desta forma de diversão, uma reparação dos danos que lhe foram causados muito mais satisfatória do que ocorreria caso houvesse julgamento e condenação". 445

Nos crimes públicos e nos crimes semi-públicos, ${ }^{446}$ se durante o inquérito tiverem sido recolhidos indícios suficientes ${ }^{447}$ acerca da existência do crime e de sua autoria, o Ministério Público, no prazo de dez (10) dias, deduzirá acusação (art. 283, 1, do CPPP), o que não dependerá de qualquer consentimento alheio. Nessa hipótese, o assistente poderá oferecer sua própria acusação, nos termos do art. 284, 1 e 2, do CPPP, ${ }^{448}$ desde que esta não implique alteração substancial dos fatos imputados na acusação pública, podendo o assistente ainda requerer a produção de prova.

Nos crimes privados, concluído o inquérito, dirigido pelo Ministério Público, este notificará o assistente para que, se o quiser, deduza em dez dias a acusação particular, no que até cinco (05) dias após a apresentação de tal acusação, poderá o Ministério Público oferecer acusação pública, pelos mesmos fatos, por parte deles ou por outros, desde que não implique uma alteração substancial daqueles. Vê-se, aqui, a inversão de papéis entre

\footnotetext{
${ }^{443}$ Conferir aprofundada análise sobre tal instituto em: FERNANDES, Fernando. O processo penal como instrumento de política criminal. Coimbra: Almedina, 2008. (Coleção teses), p. 496-574.

${ }^{444}$ Conferir as críticas sobre a não extensão de tal prerrogativa ao ofendido: FERNANDES, Fernando. O processo penal como instrumento de política criminal. Coimbra: Almedina, 2008. (Coleção teses), p. 545547.

${ }^{445}$ SANTOS. Cláudia Cruz. A "redescoberta" da vítima e o direito processual penal português. In: ANDRADE, Manuel da Costa Andrade; ANTUNES, Maria João; SOUSA; Susana Aires de. (Org.). Estudos em homenagem ao prof. doutor Jorge de Figueiredo Dias. Coimbra: Coimbra Editora, 2010. v. 3. p. 11331153 , p. 1143.

${ }^{446}$ Nos crimes semi-públicos, o legislador exige a apresentação de queixa para que o Ministério Público ofereça acusação (equivalente à representação nas ações penais de iniciativa pública condicionada à representação do processo penal brasileiro).

${ }_{447}$ "Consideram-se suficientes os indícios sempre que deles resultar uma possibilidade razoável de ao arguido vir a ser aplicada, por força deles, em julgamento, uma pena ou uma medida de segurança" (art. 283, 2, do CPPP).

448 "1 - Até 10 dias após a notificação da acusação do Ministério Público, o assistente pode também deduzir acusação pelos factos acusados pelo Ministério Público, por parte deles ou por outros que não importem alteração substancial daqueles. 2 - É correspondentemente aplicável o disposto nos n.os 3 e 7 do artigo anterior, com as seguintes modificações: a) A acusação do assistente pode limitar -se a mera adesão à acusação do Ministério Público; $b$ ) Só são indicadas provas a produzir ou a requerer que não constem da acusação do Ministério Público.”
} 
Ministério Público e assistente, quanto ao procedimento de acusação próprio de crimes públicos e semi-públicos.

Caso o assistente não apresente sua acusação no prazo legal, ao Ministério Público somente restará determinar o arquivamento do inquérito, já que não poderá oferecer acusação pública sem que haja a prévia acusação particular.

Por fim, cumpre registrar que tanto nos crimes semi-públicos quanto nos crimes privados (dependentes de acusação particular), admite-se a desistência do assistente, que será submetida a um procedimento de homologação perante o Ministério Público, em se tratando da fase de inquérito ou perante o juiz, nas fases subsequentes, e que contará com a notificação do arguido, cujo silêncio equivalerá à sua não oposição (art. 51, 1,2 e 3 , do CPPP). ${ }^{449}$

5.3.1.4 Argentina

De notar-se que o processo penal argentino ${ }^{450}$ admite um regime de ações dividido em acción pública, acción privada e acción dependiente de instancia privada. Sobre a primeira (acción pública), dispõe o art. $5^{\circ}$, do Código de Proceso Penal de la Nación, ou simplesmente, CPPN, que "se ejercerá por el ministerio fiscal, el que deberá iniciarla de oficio siempre que no dependa de instancia privada"; quanto à acción penal dependiente de instancia privada, "no se podrá ejercitar si las personas autorizadas por el Código Penal no formularen denuncia ante autoridad competente" (art. $6^{\circ}$, do CPPN); por fim, a acción privada, que "se ejerce por medio de querella, en la forma especial que establece este Código." (art. $7^{\circ}$, do CPPN).

Neste tópico, limitar-se-á ao exame da participação da vítima em ações penais

\footnotetext{
449 " 1 - Nos casos previstos nos artigos $49 .^{\circ}$ e 50. ${ }^{\circ}$, a intervenção do Ministério Público no processo cessa com a homologação da desistência da queixa ou da acusação particular. 2 - Se o conhecimento da desistência tiver lugar durante o inquérito, a homologação cabe ao Ministério Público; se tiver lugar durante a instrução ou o julgamento, ela cabe, respectivamente, ao juiz de instrução ou ao presidente do tribunal. 3 Logo que tomar conhecimento da desistência, a autoridade judiciária competente para a homologação notifica o arguido para, em cinco dias, declarar, sem necessidade de fundamentação, se a ela se opõe. A falta de declaração equivale a não oposição. 4 - Se o arguido não tiver defensor nomeado e for desconhecido o seu paradeiro, a notificação a que se refere o número anterior efectua-se editalmente."

${ }^{450}$ Cumpre observar que todas as considerações deduzidas neste tópico referem-se ao processo penal regulado no Código de Proceso Penal de la Nación, válido a nível nacional naquele país, ressalvando-se que as províncias argentinas têm autonomia para regulamentar o processo penal em âmbito local, daí a existência dos respectivos código provinciais, como os de Córdoba, Tucumán, Santa Fé etc.
} 
públicas, sob a modalidade de concurso ou cooperação.

O projeto Levene, na esteira do Código de la Provincia de Córdoba, de $1939^{451}$ que lhe servira de modelo, não contemplava a participação da vítima no processo penal, à exceção da possibilidade de exercício de ação civil. Contudo, em face das críticas surgidas, a intervenção do Ministro da Justiça León Arslanian ensejou uma maior regulamentação da matéria, passando-se a prever, inclusive, a figura do querellante particular, ${ }^{452}$ que tanta polêmica tem suscitado.

O CPPN trata da figura do querellante particular ${ }^{453}$ em seus arts. 82 a 86 . Para exercer tal função, exige-se que a pessoa tenha sido particularmente ofendida - o que remete ao conceito de titular do bem jurídico tutelado pela norma penal violada - e que tenha capacidade civil. No caso de incapacidade, atuará seu representante legal. Caso o interessado tenha falecido em decorrência do crime, a faculdade de exercer tal função recairá sobre o cônjuge supérstite do de cujus, seus pais, seus filhos ou seu último representante legal.

Para habilitar-se como querellante particular, a vítima deverá, até o encerramento da instrução, formular pedido por escrito, o qual deverá conter os requisitos previstos no art. 83, do CPPN. A negativa do pedido pode ser impugnada por apelação.

A intervenção como querellante particular não exime a vítima de prestar depoimento como testemunha nem exclui a possibilidade de constituir-se também actor civil, podendo requerê-lo em um mesmo instrumento.

Os aspectos mais polêmicos em relação ao derecho de querela concernem aos poderes que lhe são concedidos, ou mais precisamente, se o querellante particular dispõe de autonomia em sua atuação. Em não se mostrando claras as disposições legais previstas no $C P P N$, que se limita a afirmar que compete àquele impulsionar o processo, proporcionar elementos de prova e sobre estes argumentar, bem como recorrer na forma prevista no Código, a literatura jurídica e a jurisprudência debatem-se sobre o tema.

Nesse sentido, LANZÓN recorda a distinção existente entre querellante conjunto e querellante adesivo. A este caberia apenas aderir à acusação e às conclusões do

\footnotetext{
${ }^{451}$ BERTOLINO, Pedro J. La situación de la víctima del delito en el proceso penal de la Argentina. In: BERMÚDEZ, Victor Hugo et al. La víctima en el proceso penal: su régimen legal en Argentina, Bolivia, Brasil, Chile, Paraguay, Uruguay. Prefácio de Ada Pellegrini Grinover. Buenos Aires: Depalma, 1997, p. 168, p. 13.

${ }^{452}$ Cf. LANZÓN, Román P. La intervención de la víctima en el proceso penal y su derecho a actuar como querellante. In: GUZMÁN, Nicolás. (Coord.). El sistema penal en las sentencias recientes de los órganos interamericanos de protección de los derechos humanos. Buenos Aires: Ad Hoc, 2009, p. 223-250, p. 325-326.

${ }^{453} \mathrm{O}$ querellante particular não se confunde com o querellante exclusivo, este titular da acción privada.
} 
Ministério Público, tratando-se de um mero colaborador. Por outro lado, àquele caberia atuar em conjunto com o Ministério Público, porém, gozaria de alguma autonomia quanto à sua atuação, podendo, por exemplo, interpor recursos próprios. Em face de ambas as figuras, LANZÓN anota não haver consenso na literatura jurídica acerca da categoria em que se pode inserir o querellante particular. ${ }^{454}$

É certo que, conforme já visto no item 4.3.2.1.4, em face da literalidade do art. 348, do CPPN, caso o Ministério Público Fiscal (MPF) solicite o arquivamento e o querellante particular, ao contrário, requeira a elevación a juicio, deverá o juiz da instrução submeter o caso à Cámara de Apelaciones, a quem caberá a decisão. Contudo, surge o questionamento: poderá o querellante particular, em outras fases do processo, gozar também dessa autonomia, caso haja divergência com a postura do MPF?

Nesse ponto, vem à colação o paradigmático caso Santillán, julgado pela Corte Suprema de Justicia de la Nación (CSJN) em 1998. Consoante tal julgamento, a referida Corte entendeu como válido um pedido de condenação realizado por um querellante particular, apesar do pedido de absolvição formulado pelo Ministério Público, tendo em vista que o reconhecimento legal da atuação do sujeito processual no juicio - no caso, o querelante - exige que lhe seja garantida a possibilidade de atuar em defesa de seus direitos, conforme o devido processo legal, previsto no art. 18, da Constitución de la Nación. ${ }^{455}$

Cabe deixar claro que, embora o entendimento da $C S J N^{456}$ se restrinja à participação do querellante particular no juicio, foi o suficiente para abrir-se a

\footnotetext{
${ }^{454}$ LANZÓN, Román P. La intervención de la víctima en el proceso penal y su derecho a actuar como querellante. In: GUZMÁN, Nicolás. (Coord.). El sistema penal en las sentencias recientes de los órganos interamericanos de protección de los derechos humanos. Buenos Aires: Ad Hoc, 2009, p. 223-250, p. 227.

${ }^{455}$ Nas palavras de LANZÓN, "Este renombrado caso puede sintetizarse de la siguiente forma: durante el debate y pese a la pretensión desincriminante del Ministerio Público Fiscal, al momento de alegar, el particular damnificado constituido como querellante había solicitado la imposición de una pena para el enjuiciado. El Tribunal Oral que intervino en la contenda había absuelto al imputado apoyándose substancialmente en la doctrina del precedente 'Tarifeño' del Alto Tribunal, por la cual se considero que la inexistencia de acusación al momento de presentar sus conclusiones el actor penal impedía que él órgano juzgador dictara un pronunciamiento de condena. Al llegar a la Corte la causa 'Santillán', el máximo tribunal sostuvo, en cambio, que existia una acusación válida - la del querellante - por lo que no resulta válido efectuar diferencia alguna respecto del carácter público o privado de quien formulaba. Ello, toda vez que si la ley reconoce a un sujeto la posibilidad de actuar en juicio en defensa de sus derechos, éste goza de la garantia del debido proceso legal, prevista en el art. 18 de la C.N. ". (LANZÓN, Román P. La intervención de la víctima en el proceso penal y su derecho a actuar como querellante. In: GUZMÁN, Nicolás. (Coord.). El sistema penal en las sentencias recientes de los órganos interamericanos de protección de los derechos humanos. Buenos Aires: Ad Hoc, 2009, p. 223-250, p. 228).

${ }^{456}$ Conferir análise sobre a evolução da jurisprudência da CSJN até chegar ao caso Santillán: NAMER, Sabrina E. La autonomia del querelante y el derecho a la jurisdición. In: GUZMÁN, Nicolás. (Coord.). EI sistema penal en las sentencias recientes de los órganos interamericanos de protección de los derechos humanos. Buenos Aires: Ad Hoc, 2009, p. 319-352, p. 326-327.
} 
oportunidade para cortes inferiores estenderem a autonomia daquele sujeito a outras fases processuais, conforme se pode depreender dos casos Storchi e Masola, contando com o apoio de parte da literatura jurídica. ${ }^{457}$

Após Santillán, PANDOLFI chega a referir-se a uma tendência a afirmar-se o caráter autonômono do querellante particular, no que adverte para a inadmissibilidade de persecuções penais múltiplas sobre a base de discursos acusatórios alternativos e/ou diferentes formulados por diversos acusadores, tendo em vista existir um direito do acusado a um acusador penal único e a um único discurso acusatório ${ }^{458}$.

\subsubsection{Corte Interamericana de Direitos Humanos}

O sistema interamericano consiste em um dos sistemas regionais de proteção dos direitos humanos, ${ }^{459}$ o qual ostenta, como seu principal documento, a Convenção Americana de Direitos Humanos (CADH), conhecida também como o Pacto de São José, contando com a Comissão Interamericana de Direitos Humanos, ou simplesmente, a Comissão, e a Corte Interamericana de Direitos Humanos, ou simplesmente, a Corte.

A CADH constituiu a principal carta de direitos humanos das Américas, por diversos motivos: a) pela abrangência geográfica, contando com vinte e quatro (24) Estados signatários; b) por constituir um catálogo de direitos civis e políticos; c) por ter a seu favor um sistema de supervisão e controle das obrigações assumidas pelos Estados, do

\footnotetext{
${ }^{457}$ Conferir análise dos casos em: NAMER, Sabrina E. La autonomia del querelante y el derecho a la jurisdición. In: GUZMÁN, Nicolás. (Coord.). El sistema penal en las sentencias recientes de los órganos interamericanos de protección de los derechos humanos. Buenos Aires: Ad Hoc, 2009, p. 319-352, p. 327-328. LANZÓN recorda o posicionamento dominante da Sala I, da Cámara Nacional Criminal y Correcicional de la Ciudad de Buenos Aires e, em concreto, o de BRUZZONE, que estende os postulados do precedente Santillán à fase intermediária e à fase inicial do procedimento, nesse sentido citando expoentes prestigiosos da doutrina que logo após Santillán advertiram sobre os problemas interpretativos que lhe são decorrentes, como CAFFERATA NORES e MARTÍNEZ: LANZÓN. (LANZÓN, Román P. La intervención de la víctima en el proceso penal y su derecho a actuar como querellante. In: GUZMÁN, Nicolás. (Coord.). El sistema penal en las sentencias recientes de los órganos interamericanos de protección de los derechos humanos. Buenos Aires: Ad Hoc, 2009, p. 223-250, p. 231-232).

${ }^{458}$ PANDOLFI, Oscar Raúl. El derecho del imputado a um acusador penal único (o a un solo discurso acusatorio del que defenderse). Córdoba: Ediciones del Copista, 2010, passim.

${ }^{459}$ Ao lado do sistema europeu e do sistema africano. Fala-se em um inicipiente sistema árabe e se propõe a criação de um sistema asiático. Para uma melhor análise, cf. PIOVESAN, Flávia. Direitos humanos e o direito internacional constitucional. 12. ed. rev. atualiz. São Paulo: Saraiva, 2011, p. 305-311.
} 
qual fazem parte a Comissão e a Corte. ${ }^{460}$

Essa Convenção encontra-se definitivamente incorporada ao direito brasileiro por força do Decreto n. 678, de 11 de novembro de 1992, tendo o Congresso a aprovado pelo Decreto Legislativo n. 89/98. Por fim, o Brasil encaminhou nota ao Secretário-Geral da OEA, no dia 10 de novembro de 1998, reconhecendo a jurisdição obrigatória da Corte no país, sendo tal reconhecimento promulgado internamente pelo Decreto n. 4.463 , de 08 de novembro de $2002 .{ }^{461}$

Quanto ao status das normas convencionais no direito brasileiro, o Supremo Tribunal Federal entende que os tratados internacionais de direitos humanos, que não restarem aprovados pelo rito especial previsto no art. $5^{\circ}, \S 3^{\circ}$, da Constituição Federal ${ }^{462}-\mathrm{o}$ que é o caso da CADH - têm natureza supralegal: abaixo da Constituição, mas acima de toda e qualquer lei. ${ }^{463}$

A Corte trata-se de órgão autônomo, de função consultiva e jurisdicional, ao qual incumbe a função de intérprete último e de julgamento de casos por violação dos dispositivos da CADH; À Comissão, por sua vez, dentre suas funções, incumbe a postulação - juntamente com os Estados signatários - de causas junto à Corte, em decorrência de violação das normas convencionais, ${ }^{464}$ não se revestindo tal postulação,

\footnotetext{
${ }^{460}$ RAMOS, André de Carvalho. O diálogo das Cortes: o Supremo Tribunal Federal e a Corte Interamericana de Direitos Humanos. In: AMARAL JÚNIOR. Alberto (coord.). O STF e o direito internacional dos direitos humanos. São Paulo: Quartier Latin, 2009, p. 805-850, p. 814.

${ }^{461}$ RAMOS, André de Carvalho. O diálogo das Cortes: o Supremo Tribunal Federal e a Corte Interamericana de Direitos Humanos. In: AMARAL JÚNIOR. Alberto (coord.). O STF e o direito internacional dos direitos humanos. São Paulo: Quartier Latin, 2009, p. 805-850, p. 814.

${ }^{462}$ Trazido pela Emenda Constitucional n. 45, de 08 de dezembro de 2004

${ }^{463}$ RAMOS, André de Carvalho. O diálogo das Cortes: o Supremo Tribunal Federal e a Corte Interamericana de Direitos Humanos. In: AMARAL JÚNIOR. Alberto (coord.). O STF e o direito internacional dos direitos humanos. São Paulo: Quartier Latin, 2009, p. 805-850, p. 805-808. Para respeitável setor da doutrina, os tratados que versam sobre direitos humanos, diferentemente dos demais tratados internacionais, sempre têm natureza de norma constitucional material, constituindo o procedimento previsto no art. $5^{\circ}, \S 3^{\circ}$ um requisito para se tornarem normas constitucionais em sentido formal: PIOVESAN, Direitos humanos e o direito constitucional internacional, p. 103-138; LAFER, Celso. A internacionalização dos direitos humanos: constituição, racismo e relações internacionais. Bauru: Manole, 2005, p. 14-18; Cf. ainda sobre o tema: STEINER, Sylvia. A convenção americana e sua integração ao processo penal brasileiro. São Paulo: Revista dos Tribunais, 2000, p. 59-91.

464 "No regime da Convenção Americana, será a Comissão - que, neste caso, atua como instância preliminar à jurisdição da Corte - que submeterá o caso ao conhecimento da Corte, podendo também fazê-lo outro Estado pactuante, mas desde que o país acusado tenha anteriormente aceito a jurisdição do tribunal para atuar em tal contexto - ou seja, o da lide interestatal nos casos relativos a direitos humanos -, impondo ou não a condição de reciprocidade. Frise-se bem este último caso: um Estado-partre na Convenção pode peticionar diretamente à Corte contra outro Estado-parte na Convenção, à guisa de uma ação popular internacional, pois a garantia dos direitos humanos é uma obrigação objetiva que interessa a todos os seus Estados-partes. Contudo, tal jamais ocorreu (por motivos óbvios) até o presente momento no sistema americano de direitos humanos". (GOMES, Luiz Flávio; MAZZUOLI, Valério de Oliveira. Comentários à convenção americana sobre direitos humanos: Pacto San José da Costa Rica. 2. ed. rev. atualiz. e ampl. São Paulo: Revista dos Tribunais, 2009. (Coleção ciências criminais), p. 288).
} 
contudo, nem tampouco a decisão da Corte, de natureza penal. ${ }^{465}$

No que diz respeito ao direito de participação da vítima no processo penal sob a modalidade de concurso ou cooperação, no âmbito dos Estados signatários da CADH, a Corte tem apresentado os seguintes entendimentos: que do art. 8.1, ${ }^{466}$ se depreende que as vítimas e seus familiares devem contar com amplas possibilidades de serem ouvidos e de atuar em seus respectivos processos, tanto na procura do estabelecimento da verdade dos fatos e da aplicação de pena aos responsáveis, quanto na busca da devida reparação (casos Niños de la calle (Villagrán Morales)); ${ }^{467}$ que o direito à verdade se encontra compreendido no direito da vítima ou de seus familiares a obter dos órgãos estatais competentes o esclarecimentos sobre os fatos que violaram seus direitos e as respectivas responsabilidades, pela investigação e pelo julgamento assegurados nos arts. 8.1 e $25,{ }^{468}$ da Convenção (Caso Barrios Altos); ${ }^{469}$ que toda pessoa que se considere vítima e seus familiares possuem direito de ter acesso à justiça para que se cumpra, em seu benefício e de toda a sociedade, esse dever do Estado (Caso Bulacio)". ${ }^{470}$

Sobre tais julgamentos, LANZÓN atesta que "[...] si bién es cierto que la jurisprudencia interamericana relacionada con la violación de los derechos humanos le otorga a la víctima un papel importante en el proceso penal, no delimita expresamente en

\footnotetext{
${ }^{465}$ Frise-se que as demandas apresentadas pelos Estados ou pela Comissão perante a Corte Interamericana não se confundem com a justiça penal. Em outras palavras, os Estados não comparecem perante a Corte como sujeitos de uma ação penal, uma vez não ter o sistema interamericano de proteção dos direitos humanos o objetivo de impor penas às pessoas culpadas por violações dos direitos humanos, mas sim amparar as vítimas e estabelecer uma reparação aos danos a elas causados pelo Estado ou seus agentes. Apenas o Tribunal Penal Internacional (criado pelo Estatuto de Roma de 1998, com sede em Haia) tem essa competência (em matéria criminal), atualmente. (GOMES, Luiz Flávio; MAZZUOLI, Valério de Oliveira. Comentários à convenção americana sobre direitos humanos: Pacto San José da Costa Rica. 2. ed. rev. atualiz. e ampl. São Paulo: Revista dos Tribunais, 2009. (Coleção ciências criminais), p. 289).

${ }^{466}$ Art. 8.1.: "Toda pessoa tem direito a ser ouvida, com as devidas garantias e dentro de um prazo razoável, por um juiz ou tribunal competente, independente e imparcial, estabelecido anteriormente por lei, na apuração de qualquer acusação penal formulada contra ela, ou para que se determinem seus direitos ou obrigações de natureza civil, trabalhista, fiscal ou de qualquer outra natureza".

${ }^{467}$ LANZÓN, Román P. La intervención de la víctima en el proceso penal y su derecho a actuar como querellante. In: GUZMÁN, Nicolás. (Coord.). El sistema penal en las sentencias recientes de los órganos interamericanos de protección de los derechos humanos. Buenos Aires: Ad Hoc, 2009, p. 223-250, p. 246.

${ }^{468}$ Art. 25.1. "Toda pessoa tem direito a um recurso simples e rápido ou a qualquer outro recurso efetivo, perante os juízes ou tribunais competentes, que a proteja contra atos que violem seus direitos fundamentais reconhecidos pela constituição, pela lei ou pela presente Convenção, mesmo quando tal violação seja cometida por pessoas que estejam atuando no exercício de suas funções oficiais."

${ }^{469}$ LANZÓN, Román P. La intervención de la víctima en el proceso penal y su derecho a actuar como querellante. In: GUZMÁN, Nicolás. (Coord.). El sistema penal en las sentencias recientes de los órganos interamericanos de protección de los derechos humanos. Buenos Aires: Ad Hoc, 2009, p. 223-250, p. 246.

${ }^{470}$ LANZÓN, Román P. La intervención de la víctima en el proceso penal y su derecho a actuar como querellante. In: GUZMÁN, Nicolás. (Coord.). El sistema penal en las sentencias recientes de los órganos interamericanos de protección de los derechos humanos. Buenos Aires: Ad Hoc, 2009. p. 223-250, p. 246.
} 
qué carácter ésta debe actuar". ${ }^{471}$

Dessarte, embora não haja uma definição sobre os contornos do direito à participação sob a modalidade de concurso ou cooperação, tal direito, em si, encontra inquestionável amparo no texto convencional, conforme a jurisprudência da própria Corte.

Outro aspecto relativo ao direito da vítima à participação em relação à CIDH também pode ser abordado. Trata-se não propriamente da interpretação jurisprudencial que a Corte faz sobre tal direito, mas de como o direito da vítima à participação é exercido nos procedimentos que tramitam perante a própria $\mathrm{CIDH}$.

Conforme referido, somente a Comissão e os Estados signatários podem submeter um caso à decisão daquele órgão jurisdicional (ius standi in iudicio), nos termos do art. 61, da própria CADH. Contudo, algumas modificações no Regulamento da Corte têm sido observadas ao longo do tempo, denotando um movimento que pode, ao final, alçar as vítimas à condição de parte legítima para provocação da Corte Interamericana.

De fato, conforme bem asseverado por RIBEIRO e TEREZO, ${ }^{472} \mathrm{em} \mathrm{1996,} \mathrm{com}$ a terceira reforma no Regulamento da Corte, as vítimas e seus familiares foram autorizados a apresentar manifestação direta e provas durante a fase de reparações, de maneira independente daquela exposta pela Comissão Interamericana, competindo a esta representar as vítimas e seus familiares durante todas as fases do processo perante a Corte ${ }^{473}$ no ano de 2000, outra reforma processual foi verificada no Regulamento da Corte, passando-se a prever a participação direta das vítimas e de seus familiares em todas as etapas do processo.

Assim, atualmente, o Regulamento dispõe, em seu art. 23.1: "Depois de admitida a demanda, as supostas vítimas, seus familiares ou seus representantes devidamente acreditados poderão apresentar suas petições, argumentos e provas de forma autônoma durante todo o processo", enunciando ainda que na hipótese de existência de pluralidade de vítimas, familiares ou representantes, deverá ser designado um interveniente comum, que será o único autorizado a apresentar petições, argumentos e elementos de prova no curso do processo (23.2), cabendo à Corte decidir em caso de eventual

\footnotetext{
${ }^{471}$ LANZÓN, Román P. La intervención de la víctima en el proceso penal y su derecho a actuar como querellante. In: GUZMÁN, Nicolás. (Coord.). El sistema penal en las sentencias recientes de los órganos interamericanos de protección de los derechos humanos. Buenos Aires: Ad Hoc, 2009, p. 223-250, p. 245.

${ }^{472}$ RIBEIRO, Evandro de Aguiar; TEREZO, Cristina Figueiredo. Evolução do Sistema Interamericano de Direitos Humanos: o novo Direito Processual Internacional dos Direitos Humanos. Revista do Ministério Público do Estado do Pará, Belém, v.1, p. 77-90, dez. 2010, p. 78-80.

${ }^{473} \mathrm{O}$ processo instaurado na Corte teria as seguintes fases: análise das exceções preliminares, julgamento do mérito, fixação das reparações e supervisão do cumprimento da sentença.
} 
discordância (23.3).

Tais alterações em prol das vítimas e de seus familiares permitem projetar a possibilidade futura de previsão expressa, no texto convencional, conferindo àqueles o ius standi perante a Corte, ${ }^{474}$ assim como ocorre no sistema europeu de proteção dos direitos humanos, em que se assegura, desde o Protocolo n. 11/1994, a postulação direta pelos indivíduos junto ao Tribunal Europeu dos Direitos Humanos, extinguindo-se a Comissão Europeia. $^{475}$

Uma relevante vantagem decorrente da atribuição do ius standi às vítimas consiste na independência destas em relação à deliberação da Comissão, a qual exerce atualmente, de certa forma, o papel de dominus litis absoluto sobre as demandas que versem acerca de violações de direitos humanos, com base na $\mathrm{CADH}$, perante a Corte Interamericana. ${ }^{476}$

\footnotetext{
474 "Em janeiro de 1999, durante o XLIII Período Ordinário de Sessões da Corte Interamericana de Direitos Humanos, deliberou-se realizar um estudo sobre novos mecanismos para o fortalecimento do Sistema, criando-se uma Comissão, cujo relator seria o então juiz Cançado Trindade, que desenvolveu diversas atividades para cumprir com o seu objetivo, resultando num primeiro relatório entregue, em 2000, à Comissão de Assuntos Jurídicos e Políticos (CAJP) do Conselho Permanente da OEA, o que influenciou na aprovação do Regulamento da CorteIDH em comento. Um segundo relatório foi apresentado à CAJP/OEA em 2001, denominado 'Bases para um Projeto de Protocolo à Convenção Americana de Direitos Humanos, para fortalecer seu mecanismo de proteção', desenvolvido com o consentimento da Comissão Interamericana. A reforma apontada por esse Projeto à Convenção Americana seria de fundamental importância diante da natureza dinâmica e evolutiva que é própria do Direito Internacional dos Direitos Humanos, buscando contemplar, por sua vez, o caráter expansivo e histórico que acompanha os Direitos Humanos. Entre outros artigos destacados pelo Projeto em comento, verifica-se a alteração no artigo 61 (1)10 da Convenção Americana de Direitos Humanos (CADH), que passaria a ter a seguinte redação: 'Os Estados-partes, a Comissão e as supostas vítimas têm direito de submeter um caso à decisão da Corte'. Com isso, estaria garantido o acesso direto das vítimas e de seus familiares à Corte Interamericana - jus standi ,estabelecendo-se o fim do direito privativo da Comissão e do Estado de postular ação perante o órgão jurisdicional internacional em tela. Todavia, como se verifica na redação apresentada, a Comissão não seria extinta, como apontavam alguns especialistas". (RIBEIRO, Evandro de Aguiar; TEREZO, Cristina Figueiredo. Evolução do Sistema Interamericano de Direitos Humanos: o novo Direito Processual Internacional dos Direitos Humanos. Revista do Ministério Público do Estado do Pará, Belém, v.1, p. 77 90, dez. 2010, p. 79-80).

${ }^{475}$ "O Protocolo n. ${ }^{\circ} 11 / 199412$ dispõe sobre a alteração do sistema de petições previsto na Convenção Europeia, determinando que a Corte Europeia se tornasse órgão permanente, garantindo ao indivíduo o direito de postular diretamente, junto a esse Tribunal, suas demandas, e declarando a extinção da Comissão Europeia. Tal modificação não se deu de forma repentina, mas muito a par do que ocorreu no Sistema Interamericano, o primeiro passo no Sistema Europeu foi dado por meio do Protocolo n. ${ }^{\circ}$ 09/1990, o qual permitiu a presença de vítimas e seus familiares na instrução do processo, para em seguida reconhecer sua capacidade processual para a postulação direta". (RIBEIRO, Evandro de Aguiar; TEREZO, Cristina Figueiredo. Evolução do Sistema Interamericano de Direitos Humanos: o novo Direito Processual Internacional dos Direitos Humanos. Revista do Ministério Público do Estado do Pará, Belém, v.1, p. 7790, dez. 2010, p. 80).

476 "Caso a Comissão delibere pela ausência de violação de direitos humanos protegidos, o requerente (no caso de não ter sido o procedimento instaurado ex officio) não tem recurso disponível, mesmo quando a decisão favorável ao Estado não tenha sido unânime. Desse modo, a Comissão, ao exercer a faculdade de não-acionar a Corte é transformada em dominus litis absoluto da ação de responsabilidade internacional do Estado no sistema interamericano, já que o outro co-legitimado (o Estado requerido) não possui interesse algum em provocar a Corte, após a decisão favorável no âmbito da Comissão." (RAMOS, André de Carvalho. Processo internacional de direitos humanos. Rio de Janeiro: Renovar, 2002, p. 235).
} 


\subsubsection{Tribunal Penal Internacional (TPI)}

O Tribunal Penal Internacional (TPI) restou criado pelo Estatuto de Roma, de 1998, sendo definido, no art. $1^{\circ}$ do próprio Estatuto, como uma instituição permanente que poderá exercer sua jurisdição sobre as pessoas quanto aos crimes mais graves de transcendência internacional em conformidade com $\quad$ o Estatuto, ${ }^{477}$ tendo complementariedade em relação às jurisdições penais nacionais. ${ }^{478}$

Junto ao TPI tem lugar um órgão oficial de acusação, o gabinete do procurador, composto por um procurador e um ou mais procuradores-adjuntos, que poderão ser auxiliados por assessores jurídicos especializados em determinados temas como, por exemplo, violência sexual, violência por razões de gênero e violência contra crianças e adolescentes, conforme o disposto no art. 42, do Estatuto de Roma. Ao Procurador incumbirá a postulação da ação penal perante o Tribunal.

Diferentemente dos tribunais internacionais anteriormente estabelecidos, como os de Nuremberg, de Tóquio e os tribunais ad hoc para a Bósnia e a Ruanda, o TPI reconhece direitos das vítimas e permite sua viabilização no curso do processo perante tal órgão jurisdicional, denotando-se, assim, verdadeiro pioneirismo em relação à matéria.

Conforme bem observado por GONZÁLEZ, a definição do papel das vítimas no processo perante o TPI resultou de discussões travadas por representantes de países em cujos ordenamentos jurídicos o tratamento dado ao tema não se mostrava uniforme, pelo contrário.

Assim, para França, Argentina, Colômbia e Guatemala, o papel das vítimas no processo era compreendido com maior facilidade, dada a existência de institutos como a parte civil e o querellante solidario nos respectivos processos penais nacionais, em que se

\footnotetext{
${ }^{477}$ A jurisdição material do TPI compreende: crimes de genocídio (previstos no art. $6^{\circ}$, do Estatuto), crimes contra a humanidade $\left(\operatorname{art.} 7^{\circ}\right.$ ), crimes de guerra $\left(\operatorname{art.} 8^{\circ}\right.$ ) e crimes de agressão (art. $8^{\circ}$, bis, inserido pela resolução RC/Res.6, anexo I, de 11 de junho de 2010).

${ }^{478}$ Sobre a complementaridade, que se encontra prevista no art. 17, do Estatuto: "Quer dizer que o exercício da jurisdição do Tribunal fica condicionado à omissão ou incapacidade do Estado competente, de fornecer uma resposta jurídica efetiva à violação. Este princípio, de fato, tem o condão de eliminar o temor daqueles que acreditam que o TPI irá subjugar a nação ou sobrepor-se à soberania nacional. A jurisdição do Tribunal só poderá atuar se o judiciário brasileiro não quiser ou não puder fazê-lo". (VANZOLINI, Maria Patrícia. O Tribunal Penal Internacional e o processo de judicialização do Direito Internacional dos Direitos Humanos. In: PIOVESAN, Flávia; IKAWA, Daniela (Coord.). Direitos humanos: fundamento, proteção e implementação. Curitiba: Juruá, 2007, Vol. 2, p. 242-262, p. 257).
} 
assegura à vítima um papel independente do Ministério Público, ao passo que para os países pertencentes ao common law, tratava-se de um tema que lhes era completamente alheio. $^{479}$

O resultado dessas discussões travadas por representantes de sistemas jurídicos diversos consiste em um sistema misto: "esta mezcla trajo consigo la inclusión de un inovador sistema de justicia que reconoce la importancia de las víctimas em la lucha contra la impunidad y les otorga un papel autónomo". 480

$\mathrm{O}$ art. 85 do Estatuto de Roma define as vítimas como pessoas naturais que tenham sofrido um dano como consequência da prática de algum crime da competência do TPI - não se adentrando em detalhes quanto à natureza do dano sofrido -, bem como organizações ou instituições que tenham sofrido danos diretos a algum de seus bens que esteja dedicado à religião, à educação, às artes, às ciências, ou a beneficência e a seus monumentos históricos, hospitais e outros lugares e objetos que tenham fins humanitários.

A atuação das vítimas encontra previsão no art. 68(3) do Estatuto de Roma, ${ }^{481}$ o qual estabelece que o TPI permitirá, nas fases do julgamento que considere convenientes, que sejam apresentados e sejam levados em consideração as opiniões e observações das vítimas caso se vejam afetadas em seus interesses pessoais, de modo que não resulte em detrimento dos direitos do acusado ou da garantia de um juízo justo e imparcial e que não haja incompatibilidade com estes.

Para o exercício de tais direitos, o interessado deverá apresentar requerimento escrito junto ao Secretário do Tribunal (art. 86, do Regulamento do Tribunal), o qual será

\footnotetext{
479 VEGA GONZÁLEZ, Paulina. O papel das vítimas nos procedimentos perante o Tribunal penal internacional: seus direitos e as primeiras decisões do Tribunal. SUR: Revista Internacional de Direitos Humanos, São Paulo, v. 3, n. 5, p. 18-41, jul./dez. 2006. Disponível em: $<$ http://bdjur.stj.gov.br/dspace/handle/2011/22644>. Acesso em: 8 jun. 2009.

480 VEGA GONZÁLEZ, Paulina. O papel das vítimas nos procedimentos perante o Tribunal penal internacional: seus direitos e as primeiras decisões do Tribunal. SUR: Revista Internacional de Direitos Humanos, São Paulo, v. 3, n. 5, p. 18-41, jul./dez. 2006. Disponível em: <http://bdjur.stj.gov.br/dspace/handle/2011/22644>. Acesso em: 8 jun. 2009, p. 20. As normas que fazem referência à intervenção das vítimas encontram-se não somente no Estatuto de Roma, mas também no Regulamento do Tribunal, no Regulamento da Secretaria do Tribunal e no Regulamento sobre Procedimento e Provas. (VEGA GONZÁLEZ, Paulina. O papel das vítimas nos procedimentos perante o Tribunal penal internacional: seus direitos e as primeiras decisões do Tribunal. SUR: Revista Internacional de Direitos Humanos, São Paulo, v. 3, n. 5, p. 18-41, jul./dez. 2006. Disponível em: $<$ http://bdjur.stj.gov.br/dspace/handle/2011/22644>. Acesso em: 8 jun. 2009, p. 21).

481 "La Corte permitirá, en las fases del juicio que considere conveniente, que se presenten y tengan en cuenta las opiniones y observaciones de las víctimas si se vieren afectados sus intereses personales y de una manera que no redunde en detrimento de los derechos del acusado o de un juicio justo e imparcial ni sea incompatible con éstos. Los representantes legales de las víctimas podrán presentar dichas opiniones y observaciones cuando la Corte lo considere conveniente y de conformidad con las Reglas de Procedimiento y Prueba". (ESTATUTO DE ROMA DE LA CORTE PENAL INTERNACIONAL. Disponível em: $<$ http://www.icc-cpi.int $>$. Acesso em: 17 jan. 2012).
} 
apreciado pelo TPI, podendo ser determinadas informações adicionais tanto pelo Secretário quanto pelo próprio Tribunal. Ao TPI, assim, cabe deliberar sobre a admissão ou não do requerente na condição de vítima.

Quanto ao momento de tal participação, segundo KAMIMURA, “o tribunal já decidiu sobre o exercício do direito de participação e considerou que as vítimas podem exercer esse direito em qualquer etapa dos procedimentos, ou seja, tanto em fase de inquérito, quanto no processo, inclusive apelação, e na reparação", ${ }^{482}$ devendo a vítima postular sua admissão, se possível, no início de cada fase de que deseje participar, conforme o disposto no art. 86(3), do Regulamento do Tribunal.

Para viabilizar tal participação, o Regulamento sobre Procedimento e Provas, dispõe em seu art. 16, que incumbe ao Secretário do Tribunal, dentre outras medidas, enviar avisos ou notificações às vítimas ou a seus representantes legais sobre os atos processuais, sendo que o art. 81 do Regulamento do Tribunal dispõe sobre a criação de um gabinete público de defesa das vítimas, ao qual incumbirá a assistência às vítimas que participem do processo perante o TPI.

Por fim, apenas a título de informação, ao final do processo poderão ser impostas penas de prisão (por tempo determinado ou por toda a vida do acusado) ou de multa e, acessoriamente, a perda de bens obtidos pelo acusado com a prática do crime, bem como a reparação dos danos eventualmente causados às vítimas, prevendo-se, no Estatuto de Roma, a criação de um fundo de indenização em prol daquelas (art. 79). ${ }^{483}$

\subsubsection{Identificando o fundamento para a participação do assistente no processo penal: o direito à tutela jurisdicional efetiva}

\footnotetext{
${ }^{482}$ KAMIMURA, Akemi. Os direitos das vítimas de violência nos sistemas internacionais de proteção aos direitos humanos: breve análise do sistema global e interamericano. Disponível em: $<$ http://gedi.objectis.net/artigos/Akemi_Kamimura_-_paper.pdf/viewp>. Acesso em: 17 jan. 2012, p. 10. Sobre as fases do procedimento, pode-se dizer que o inquérito é conduzido pelo procurador, ao passo que a instrução é conduzida pelos juízes do Tribunal. Preveem-se incidentes de detenção ou de prisão preventiva, durante o inquérito ou o processo. O processo se divide em duas fases: instrução e julgamento. Finda a instrução, será proferida uma sentença de pronúncia ou de impronúncia do acusado, cabendo sobre as decisões de mérito recurso ou revisão perante o próprio TPI. (COMPARATO, Fábio Konder. A afirmação histórica dos direitos humanos. 6. ed. São Paulo: Saraiva, 2010, p. 478-479).

${ }^{483}$ COMPARATO, Fábio Konder. A afirmação histórica dos direitos humanos. 6. ed. São Paulo: Saraiva, 2010 , p. 479.
} 
$\mathrm{O}$ direito à tutela jurisdicional ou de acesso à Justiça encontra expressa e destacada previsão no ordenamento jurídico brasileiro. Assim, a Constituição Federal, em seu art. 5', inciso XXXV, prevê, como direito fundamental, que "a lei não excluirá da apreciação do Poder Judiciário lesão ou ameaça a direito".

A Convenção Americana de Direitos Humanos, por sua vez, estabelece em seu art. 25.1: "Toda pessoa tem direito a um recurso simples e rápido ou a qualquer outro recurso efetivo, perante os juízes ou tribunais competentes, que a proteja contra atos que violem seus direitos fundamentais reconhecidos pela Constituição, pela lei ou pela presente Convenção [...]".

Sobre tal dispositivo convencional, anotam GOMES e MAZZUOLI que "a palavra 'recurso' [...] deve ser compreendida não só em seu sentido estrito de 'recurso propriamente dito' (contra uma decisão já proferida), senão também no seu sentido jurídico mais amplo de meio ou instrumento jurídico adequado à defesa de um direito"484, enfatizando referidos autores, ainda, a importância desse direito, advertindo que este carece não apenas de previsão formal, mas também de efetividade. ${ }^{485}$

Segundo MARINONI, a importância desse direito é de fácil assimilação: "É sabido que o Estado, após proibir a autotutela, assumiu o monopólio da jurisdição. Como contrapartida dessa proibição, conferiu aos particulares o direito de ação [...]". 486

Para DUARTE, o acesso à justiça tem o seguinte enquadramento principiológico: a) a Dignidade da Pessoa Humana, que seria sua base jusfundamental: “A dignidade da pessoa humana só pode, em termos potenciais, ser alvo de veraz proteção e garantia, enquanto aos cidadãos for assegurada a possibilidade de recorrer ao Poder Judiciário para a tutela dos seus direitos [...]"; ${ }^{487}$ b) por imposição do princípio do Estado de Direito e princípio democrático: "Não se pode falar, absolutamente, em Estado democrático de direito sem que seja garantida, em toda sua plenitude, a possibilidade de, em igualdade de condições, socorrer-se dos tribunais para a tutela das respectivas posições

\footnotetext{
${ }^{484}$ GOMES, Luiz Flávio; MAZZUOLI, Valério de Oliveira. Comentários à convenção americana sobre direitos humanos: pacto San José da Costa Rica. 2. ed. rev. atualiz. e ampl. São Paulo: Revista dos Tribunais, 2009. (Coleção ciências criminais), p. 172.

485 “O acesso à jurisdição, na visão da Corte Interamericana de Direitos Humanos, constitui um dos pilares básicos do Estado de Direito Democrático. Mas não basta que os recursos existam formalmente, ao contrário, devem ser efetivos." (GOMES, Luiz Flávio; MAZZUOLI, Valério de Oliveira. Comentários à convenção americana sobre direitos humanos: pacto San José da Costa Rica. 2. ed. rev. atualiz. e ampl. São Paulo: Revista dos Tribunais, 2009. (Coleção ciências criminais), p. 172).

${ }^{486}$ MARINONI, Luiz Guilherme. Técnica processual e tutela dos direitos. 3. ed. rev. atualiz. São Paulo: Revista dos Tribunais, 2010, p. 139.

${ }^{487}$ DUARTE, Ronnie Preuss. Garantia de acesso à justiça: os direitos processuais fundamentais. Coimbra: Coimbra Editora, 2007, p. 87.
} 
jurídicas subjetivas". ${ }^{488}$

É importante assinalar que não se pode conceber o direito à tutela jurisdicional - alçado a direito fundamental no ordenamento jurídico brasileiro - sem que seja dotado de efetividade. Daí falar-se em direito à tutela jurisdicional efetiva.

Desse modo, não basta assegurar aos que invocam lesão ou ameaça ao direito a existência de um processo. Faz-se necessário também assegurar, no âmbito desse processo, a disponibilização de todos os meios e recursos necessários para a proteção dos direitos subjetivos invocados.

Sob essa ótica, o processo deve ser efetivo, “apto a entregar, com o máximo de proveito e adequação, a tutela jurisdicional a quem, por meio do processo, resulte merecedor da resposta do Estado-Juiz, aproximando-se ao máximo da realização que o direito material atribui a quem o titularize". 489

Assimilado, em linhas gerais, o direito à tutela jurisdicional efetiva, há de se questionar se a vítima, como assistente, pode ter direito a essa tutela jurisdicional no processo penal e, em caso positivo, em que medida.

Convém tornar ao Direito Penal. Recorde-se que a prática da infração penal enseja, a princípio, a violação de interesses do sujeito passivo (vítima, sob a acepção penal), a saber, a vida, a integridade física, a honra etc., a ser captada em cada caso concreto. Esses mesmos interesses, com a publicização do Direito Penal e dada sua relevância, constituem objeto das normas jurídicas penais incriminadoras, tornando também o Estado, de certa forma, sujeito passivo da infração penal. ${ }^{490}$

Embora BITTENCOURT pareça fazer uma distinção entre interesse tutelado pela norma penal (afeto ao Estado) e interesse concreto lesado ou ofendido pelo delito (afeto à vítima), ${ }^{491}$ parece tratar-se, na verdade, do mesmo interesse, que apresenta uma

${ }^{488}$ DUARTE, Ronnie Preuss. Garantia de acesso à justiça: os direitos processuais fundamentais. Coimbra: Coimbra Editora, 2007, p. 88-89.

${ }^{489}$ SOARES, Rogério Aguiar Munhoz. Tutela jurisdicional diferenciada: tutelas de urgência e medidas liminares em geral. São Paulo: Malheiros, 2000, p. 68.

490 "Tornando-se público o direito penal, reservou o Estado para si o direito de punir, vedando a vingança privada; por isso, grande parte da doutrina ressaltou ser ele sujeito passivo constante de todo crime. Como as normas penais, nessa linha de pensamento, visariam a uma prevenção geral e especial da criminalidade e, assim, tutelar valores fundamentais da pessoa humana e da sociedade, a violação do preceito incriminador representa sempre afronta aos interesses do Estado na preservação da ordem, da garantia de paz pública, ou individual e na proteção da sociedade e de seus membros. Ademais, sendo titular exclusivo do 'ius puniendi', teria o Estado sempre interesse em que fossem descobertos, acusados e condenados os autores dos crimes." (FERNANDES, Antônio Scarance. O papel da vítima no processo criminal. São Paulo: Malheiros, 1995, p. 45).

${ }^{491}$ BITTENCOURT parece fazer uma distinção entre interesse tutelado pela norma penal e interesse concreto lesado ou ofendido pelo delito: "O sujeito passivo de todos os delitos é o Estado-administração, que é titular do interesse tutelado pela norma penal. Mas ao lado desse sujeito passivo constante de todos os 
dupla titularidade, a depender da perspectiva em que seja considerado: sob uma perspectiva mais concreta, uma titularidade atribuível à vítima (sujeito passivo, na acepção jurídico-penal), e sob uma perspectiva mais abstrata, uma titularidade atribuível ao Estado.

Ocorre que essa perspectiva de titularidade da vítima tem sido tradicionalmente menoscabada pela dogmática penal, sobrepondo-se a perspectiva da titularidade estatal, o que leva ESER a buscar um equilíbrio nessa relação entre a vítima concreta e os interesses gerais defendidos pelo Estado, eliminando a desigualdade favorável ao Estado em detrimento da tutela da vítima.. ${ }^{492}$

Daí, ponderar ESER que, se de um lado, é correto ver no delito algo mais que uma mera ofensa individual - do que decorre ser a lesão geral do direito irrenunciável como elemento do Unrecht (ilícito) -, por outro lado, porém, a violação do interesse individual só em parte pode ser absorvida por tal ofensa geral. Assim, como o autor marca presença no conceito de delito por meio de sua conduta ilícita e culpável, também a ofensa do interesse individual da vítima deve estar contida no conceito de ilícito penal, ao lado da ofensa ao bem jurídico geral. ${ }^{493}$

Constatando-se que a prática da infração penal afeta indiscutivelmente interesses jurídicos concretos da vítima (vida, integridade física, honra etc.), interesses esse que, sob um viés abstrato, também constituem objeto da norma penal incriminadora, não há como se negar à vítima o acesso à Justiça a fim de se obter uma resposta a tal violação.

De fato, conforme já asseverado, a própria Convenção Americana de Direitos Humanos assegura a todos o direito de acesso, por meios simples e tempestivos, à Justiça, na busca de proteção a seus direitos fundamentais reconhecidos pela Constituição, pela Convenção ou por lei, o que se estende às vítimas de infração penal, ${ }^{494}$ tendo as normas

delitos, há o sujeito passivo eventual, que é o titular do interesse concreto lesado ou ofendido pelo delito". (BITTENCOURT, Edgar de Moura. Vítima. 2. ed. São Paulo: LEUD, 1978, p. 81).

492 "L'obiettivo di queste riflessioni consiste piuttosto nel tentativo di dare un equilibrio al rapporto tra il soggetto leso in concreto e gli interessi generali difesi dal Stato, eliminando la sperequazione favorevole a questi ultimi a scapito della tutela del primo." (ESER, Albin. Bene giuridico e vittima del reatto: prevalenza dell'uno sull'altra? Rivista Italiana di Diritto e Procedura Penale, Milão, ano XL, fasc. 1, p. 1061-1084, genn./mar. 1997, p. 1082)

493 "Se, da un latto, è corretto ravvisare nel reato qualcosa di piu che una mera offesa individuale, e se quindi la lesione generale del diritto è irrinunciabile come elemento dell"Unrecht', dall'altro, tuttavia, la violazione dell'interesse individuale solo in parte può dissolversi in tale offesa generale. Così, como l'autore é presente nel concetto di reato attraverso la sua condota illecita e colpevole, anche l'offesa dell'interesse individuale della vittima colpita deve essere contenuta nel concetto di ilecito penale accanto alla offesa dele bene giuridico generale." (ESER, Albin. Bene giuridico e vittima del reatto: prevalenza dell'uno sull'altra? Rivista Italiana di Diritto e Procedura Penale, Milão, ano XL, fasc. 1, p. 1061-1084, genn./mar. 1997, p. 1083).

494 "O acesso à jurisdição, de outro lado, está assegurado para as vítimas (Informe Anual da Comissão Interamericana de Direitos Humanos, Argentina, 1992-1993, p.49) ou, em geral, paras as vítimas de violação de direitos humanos (Corte Interamericana de Direitos Humanos, Sentença de 26.06.87, parágrafo 93. No 
convencionais plena vigência no ordenamento jurídico brasileiro.

Faz-se importante recordar que, segundo as proposições deste trabalho, não importa a natureza dos interesses que movem a atuação da vítima (cíveis ou não), até mesmo pelo subjetivismo próprio da matéria.

$\mathrm{Na}$ verdade, toda e qualquer atuação da vítima no processo penal deve justificar-se sob a necessidade de se afirmar a dignidade da vítima, em obediência às emanações do Princípio da Dignidade da Pessoa Humana, o qual, por sua vez, assegura à vítima da infração penal, notadamente na condição de assistente, o direito fundamental à tutela jurisdicional efetiva.

Frise-se, por fim, o aspecto da efetividade em relação à atuação da vítimaassistente. Como já se asseverou, a tutela jurisdicional deve ser garantida mediante a disponibilização de todos os meios e recursos necessários à proteção dos direitos subjetivos invocados.

Assim, uma mera atuação formal, nos moldes de um convidado de pedra, presente, mas imóvel e impotente, não haverá de satisfazer as exigências da Dignidade da Pessoa Humana. Uma atuação marginal, secundária, supletiva pode mesmo ensejar o desencadeamento de outro processo de vitimização, a vitimização secundária.

\subsubsection{A bilateralidade dos direitos e garantias}

O reconhecimento, em prol da vítima-assistente, do direito fundamental à tutela jurisdicional efetiva haverá necessariamente de suscitar o tema da bilateralidade dos direitos e garantias. De fato, o direito fundamental da vítima à tutela jurisdicional efetiva enseja que direitos e garantias antes estabelecidos apenas em prol do acusado, protegendoo contra o Estado e sua persecução penal, também poderão ser invocados em favor das vítimas da infração penal, tais como o direito à produção probatória, o direito à impugnação de decisões judiciais etc.

Tendo em vista o modelo tradicional de processo penal, fulcrado no conflito,

mesmo sentido: Sentença de 31.01.2001, parágrafo 103). O acesso à jurisdição, da mesma maneira, não pode ser negada aos familiares da vítima (Corte Interamericana, Caso Blake, Sentença de 24.01.98, parágrafo 97). [...]". (destaque do autor). (GOMES, Luiz Flávio; MAZZUOLI, Valério de Oliveira. Comentários à convenção americana sobre direitos humanos: pacto San José da Costa Rica. 2. ed. rev. atualiz. e ampl. São Paulo: Revista dos Tribunais, 2009. (Coleção ciências criminais), p. 173-174). 
certamente essa bilateralidade haverá de ensejar situações de choque, em que direitos e garantias do acusado entrarão em rota de colisão com direitos e garantias da vítima, o que se dá em especial quanto à participação da vítima no processo penal na condição de assistente, fazendo-se mister, assim, estabelecer estratégias de como se deve enfrentar essas hipóteses de colidência. ${ }^{495}$

Desde já, deve-se advertir que a pretendida bilateralidade não pode, em absoluto, implicar o lamentável retrocesso histórico vislumbrado por uma supressão dos direitos e garantias do ofensor, preocupação essa que, segundo SUBIJANA ZUNZUNEGUI, move a todos os que tratam do tema, refutando-se o que restou denominado por MARTÍNEZ ARRIETA de teoria dos vasos comunicantes, ${ }^{496}$ à qual este autor opõe uma necessária harmonização entre os direitos da vítima e os do ofensor. ${ }^{497}$

$\mathrm{Na}$ verdade, a bilateralidade de direitos e garantias traz à luz o tema da relatividade dos direitos fundamentais, ${ }^{498}$ na medida em que propicia hipóteses de

\footnotetext{
495 "Hasta ahora, los organismos de derechos humanos bregaban por limitar al Estado en el ejercicio de su poder a la hora de enfrentarse al imputado, existiendo un consenso en la consideración de las garantías constitucionales como límites estatales para proteger los derechos humanos del imputado. Este paradigma fue cambiando, y se dio lugar a lo que se conoce como 'bilateralidad' de las garantias judiciales, que trae aparejada la dificuldade natural del uso de una misma herramienta para proteger víctimas e imputados cuando sus intereses son opuestos, situación que implica, casi por definición, que aquella decisión que beneficiará a uno perjudicará a outro. Por esta razón, el concepto de 'bilateralidad de las garantias' con el que se intenta justificar el derecho de las víctimas a participar activamente en el proceso en procura de la obtención de uma condena, en algún momento deberá ser definido e delimitado, si no quiere llegarse a situaciones extremas, que prácticamente pongan a los jueces en supuestos de colisión de deberes[...]". (NAMER, Sabrina E. La autonomia del querelante y el derecho a la jurisdición. In: GUZMÁN, Nicolás. (Coord.). El sistema penal en las sentencias recientes de los órganos interamericanos de protección de los derechos humanos. Buenos Aires: Ad Hoc, 2009, p. 319-352, p. 344-345).

496 "Centrándonos em la defensa de los derechos de las víctimas en el proceso penal, la preocupación latente en todos los especialistas, que se han acercado a este tema, se centra em disipar toda sombra de duda sobre el posible menoscabo de los derechos del victimário anudable a um reforzamiento de la posición jurídica de las víctimas. En otras palabras, utilizando expresiones de MARTÍNEZ ARRIETA, se trata de refutar la teoria de los vasos comunicantes según la cual '...un mayor protagonismo y efectividad de los derechos de la víctima suponga, necessariamente, um menoscabo de los derechos de los imputados en el proceso penal..."”. (SUBIJANA ZUNZUNEGUI, Ignacio José. Los derechos de la víctima: su plasmación en el proceso penal. Revista del Poder Judicial, Madrid, n. 54, p. 165-210, 1999, p. 173).

497 O próprio MARTÍNEZ ARRIETA defende essa harmonização, que se traduz, segundo suas próprias palavras em "un equilibrio preocupacional en el estudio de ambos os sujetos, y en consecuencia, a un respeto real y operativo de su posición, y a uma protección armónica de los derechos que asisten a quienes transgreden el orden social establecido y a quienes son víctimas[...]". (MARTÍNEZ ARRIETA, Andrés. La víctima en el proceso penal. Revista Actualidad Penal, Madrid, v. 1, 1/26, p.41-48, semanal. 1990, p. 42). 498 "No plano jurídico-positivo, é intuitivo que a ampla gama de direitos consagrada nos textos constitucionais induz à necessidade de harmonizá-los entre si e com outros valores ou bens protegidos pela ordem jurídica. Como destaca Jean-François Renucci, 'a limitação dos direitos do homem se impõe em nome de um certo pragmatismo associado a uma preocupação com a efetividade: o absolutismo dos direitos do homem conduziria certamente a uma ampla ineficácia."” (PEREIRA, Jane Reis Gonçalves. Interpretação constitucional e direitos fundamentais: uma contribuição ao estudo das restrições aos direitos fundamentais na perspectiva da teoria dos princípios. Rio de Janeiro: Renovar, 2006, p.133).
} 
colidência $^{499}$ entre os direitos invocáveis, por um lado, pela vítima da infração penal, e de outro, os direitos invocáveis pelo acusado.

Nesse ponto, deve-se deixar claro que, não obstante haja uma especial preocupação da ordem jurídico-constitucional em conferir ampla tutela jurídica ao acusado, como proteção ao manejo arbitrário do ius puniendi estatal, os direitos e garantias do réu não podem ser interpretados como se absolutos fossem, como se tratasse de uma singular categoria de superdireitos, situados no ápice de uma hierarquia jurídica, insuscetíveis de sofrer limitações em sua incidência. ${ }^{500}$

Com base em PEREIRA, ${ }^{501}$ pode-se afirmar que a colidência entre direitos fundamentais e, consequentemente, as restrições daí decorrentes, podem ser verificadas no plano abstrato (plano legislativo) ou no plano concreto (plano aplicativo).

Assim, as restrições abstratas (legais) referem-se a "alterações no conteúdo objetivo dos direitos fundamentais", de modo que "o recorte operado pelas leis restritivas determina o âmbito de proteção legal vigente no direito, transformando seu conteúdo constitucional prima facie em conteúdo legal definitivo"; as restrições aplicativas verificam-se no plano concreto e individual, "repercutindo na dimensão subjetiva dos direitos fundamentais, sem afetar seu conteúdo objetivo anunciado na Constituição e nas leis restritivas".

\footnotetext{
${ }^{499}$ A admissibilidade de hipóteses de colidência entre direitos fundamentais restringe-se aos partidários da teoria externa dos limites dos direitos fundamentais, pois que os defensores da teoria interna negam a possibilidade de limitações externas a tais direitos, focando a análise na determinação da esfera normativa (âmbito de proteção) de cada direito fundamental. Conferir análise sobre referidas teorias em: PEREIRA, Jane Reis Gonçalves. Interpretação constitucional e direitos fundamentais: uma contribuição ao estudo das restrições aos direitos fundamentais na perspectiva da teoria dos princípios. Rio de Janeiro: Renovar, 2006, p. 140-152.

500 Sobre possível hierarquização de direitos fundamentais na Constituição Federal de 1988: “[...] A Constituição brasileira de 1988 é ilustrativa nesse sentido. É que se fosse possível, ou mesmo desejável, que os diversos direitos fossem hierarquizados em abstrato, as preferências deveriam ser estabelecidas pelo próprio constituinte. Isso porque a priorização irrestrita de certos direitos em detrimento de outros traz subjacente uma escolha por determinada teoria da justiça, tendo, assim, um inegável caráter ideológico. E, embora seja certo que a interpretação constitucional não é imune à ideologia e a juízos morais, admitir que opções valorativas não previstas constitucionalmente sejam cristalizadas e perpetuadas por meio de hierarquias jurisprudenciais absolutas implicaria menosprezar o papel do constituinte democrático. A não previsão destas hierarquias no texto constitucional visa exatamente a conferir flexibilidade ao processo hermenêutico, e seria um contrassenso que este restasse enrijecido com base nas preferências axiológicas dos intérpretes." (PEREIRA, Jane Reis Gonçalves. Interpretação constitucional e direitos fundamentais: uma contribuição ao estudo das restrições aos direitos fundamentais na perspectiva da teoria dos princípios. Rio de Janeiro: Renovar, 2006, p. 248). Especificamente em relação ao tema: "No processo penal, ademais dos interesses estatais na persecução penal, há outros interesses em jogo que podem, em tese, ensejar a restrição aos direitos fundamentais do acusado, na hipótese de colisão. Dentre tais interesses, avulta a importância da tutela dos direitos fundamentais de outros participantes processuais [...]". (MALAN, Diogo Rudge. Direito ao confronto no processo penal. Rio de Janeiro: Lumen Juris, 2009, p. 136).

${ }^{501}$ A distinção e as citações deste parágrafo podem ser conferidas em: PEREIRA, Jane Reis Gonçalves. Interpretação constitucional e direitos fundamentais: uma contribuição ao estudo das restrições aos direitos fundamentais na perspectiva da teoria dos princípios. Rio de Janeiro: Renovar, 2006, p.205.
} 
No plano abstrato (legislativo), cabem as observações de SUBIJANA ZUNZUNEGUI, que insiste na delimitação, em relação aos direitos fundamentais do acusado, de um núcleo essencial, intangível e irrestringível, distinto do âmbito exógeno de tais direitos, por sua vez tangível e restringível. ${ }^{502}$

Tais observações nada mais são do que uma aplicação do princípio do conteúdo essencial dos direitos fundamentais, originário da Lei Fundamental de Bonn (1949), que assegurava em seu art. 19, que "em nenhum caso, pode um direito fundamental ser afetado em seu conteúdo essencial", 503 em evidente proteção dos direitos fundamentais em relação à função legislativa.

Em sua vertente absoluta, ${ }^{504}$ o conteúdo essencial do direito fundamental implica o reconhecimento de duas partes distintas no direito fundamental: a parte essencial (núcleo fixo e intangível) e a parte não essencial, a qual se mostra suscetível de restrição.

Por essa perspectiva, no plano abstrato ou legislativo, os direitos e garantias do acusado, mesmo em conflito com os direitos e garantias das vítimas da infração penal, ainda que venham a sofrer alguma tipo de restrição, essa nunca poderá atingir-lhes o núcleo essencial, impedindo-se, assim, o retrogarantismo no processo penal.

Passando-se ao plano concreto ou aplicativo, em face de tais hipóteses de colidência, deve-se levar a cabo a solução da ponderação, que pode ser definida como uma operação hermenêutica que permite o contrabalanceamento de "bens ou interesses constitucionalmente protegidos que se apresentem em conflito em situações concretas, a fim de determinar, à luz das circunstancias do caso, em que medida cada um deles deverá ceder ou, quando seja o caso, qual deverá prevalecer". 505

Essa ponderação de bens e interesses não cria regras de precedência a priori, apenas estabelece uma relação de precedência válida tão somente no caso concreto,

\footnotetext{
502 "[...] más allá de formulaciones abstractas, el debate se centra en deslindar el núcleo esencial de los derechos fundamentales del victimário, ámbito de necesaria preservación, para no desvirtuar su posición jurídica en um Estado de Derecho, aun en caso de fricción con los derechos de las víctimas. [...]. Por lo tanto, en la delimitación de la posición jurídica del victimario cabe discernir un núcleo essencial, que no puede ser menoscabado en ningún caso, y un ámbito exógeno al núcleo esencial, que sí permite injerencias y restricciones configuradas por motivaciones victimológicas." (SUBIJANA ZUNZUNEGUI, Ignacio José. Los derechos de la víctima: su plasmación en el proceso penal. Revista del Poder Judicial, Madrid, n. 54, p. 165-210, 1999, p. 173-174).

${ }^{503}$ Conferir exposição completa sobre o princípio em: PEREIRA, Jane Reis Gonçalves. Interpretação constitucional e direitos fundamentais: uma contribuição ao estudo das restrições aos direitos fundamentais na perspectiva da teoria dos princípios. Rio de Janeiro: Renovar, 2006, p. 366-382.

${ }^{504}$ A vertente relativa (teoria relativa) limita-se a afirmar que o conteúdo essencial consiste apenas na necessidade de justificar as restrições operadas nos direitos fundamentais.

${ }^{505}$ PEREIRA, Jane Reis Gonçalves. Interpretação constitucional e direitos fundamentais: uma contribuição ao estudo das restrições aos direitos fundamentais na perspectiva da teoria dos princípios. Rio de Janeiro: Renovar, 2006, p. 261.
} 
suscitando o surgimento de uma hierarquia móvel. ${ }^{506}$

Aludida restrição casuística - cumpre ressalvar - não teria o condão de implicar, por óbvio, a supressão daquele direito fundamental em especial. Na verdade, cuida-se do resultado da acomodação entre os direitos colidentes no caso concreto.

Assim, faz-se possível a garantia das bilateralidades dos direitos e garantias em processo penal, estendendo-se, às vítimas, direitos e garantias do acusado. Claro que a viabilização dessa bilateralidade trará consequências para a esfera jurídico-processual do acusado, restringindo-lhe, em algumas hipóteses - previstas em lei ou em razão da necessidade do caso concreto -, direitos que lhe são conferidos. Não se deve olvidar repise-se - que essa interferência no universo jurídico do acusado não se mostra absurda, tendo em vista a relatividade dos direitos, mesmo os dotados constitucionalmente de caráter fundamental.

O que se deve evitar é a supressão dos direitos do acusado, cabendo, nesse ponto, um alerta sobre possíveis excessos do movimento vitimológico. Assim, como bem lembra HIRSCH, deve-se evitar o risco de uma Política Criminal de ponto de vista unilateral, ${ }^{507}$ um vitimocentrismo, que, segundo CÂMARA, implicaria uma "cominuição dos direitos e garantias do delinquente (forjados com tanto sacrifício histórico)" 508

Deve-se, assim, manter a atenção redobrada, pois qualquer investida sob o rótulo vitimológico, que tenha por efeito implicar a supressão dos direitos e garantias penais e processuais penais do acusado pode acobertar, na verdade, pensamentos criminológicos ultraconservadores, sob um falso discurso de proteção às vítimas. Cabe aqui, como uma luva, a admoestação evangélica: "Attenditi a falsis prophetis, qui veniunt ad vos in vestimentos ovium, intrinsecus autem sunt lupi rapaces". ${ }^{509}$ Não passaria tal discurso, assim, de estratégias de lobos vestidos sob a pele de cordeiro...

$\mathrm{Na}$ verdade, ao Estado deve incumbir o reconhecimento dos direitos processuais de ambos, tanto do acusado quanto da vítima. O reconhecimento dos direitos

506 PEREIRA, Jane Reis Gonçalves. Interpretação constitucional e direitos fundamentais: uma contribuição ao estudo das restrições aos direitos fundamentais na perspectiva da teoria dos princípios. Rio de Janeiro: Renovar, 2006, p. 264.

507 “[...] se debe aprobar en principio la actual dedicación intensiva a la posición del ofendido en el Derecho penal y Derecho procesal penal, si bien por outra parte ésta, como todos los movimientos políticocriminales de tipo pendular, entraña el peligro de un nuevo punto de vista unilateral." (HIRSCH, HansJoachim. La posición del ofendido en el derecho penal, con la especial referencia a la reparación. Cuadernos de política criminal, Madrid, n. 42, p. 561-575, 1990, p. 562).

508 CÂMARA, Guilherme Costa. Programa de política criminal orientado para a vítima do crime. São Paulo: Editora Revista dos Tribunais; Coimbra: Coimbra Editora, 2008, p. 150.

509 "Guardai-vos dos falsos profetas, que vêm a vós disfarçados de ovelhas, mas por dentro são lobos ferozes.” Mt, 7, 15 (GORGULHO, Gilberto da Silva; STORNIOLO, Ivo; ANDERSON, Ana Flora. Bíblia de Jerusalém. São Paulo: Paulus, 2002). 
daquele, fruto de esforço histórico cujo início remonta ao iluminismo penal e se estende até nossos dias, não impede o reconhecimento dos direitos dessa última, cujo processo histórico tem, por marco inicial, a segunda metade do século XX.

O reconhecimento dos direitos da vítima, assim, deve condicionar-se sempre a uma garantia de não retrocesso dos direitos já reconhecidos ao autor do delito, de modo a evitar-se qualquer manobra que tenha por condão suprimi-los.

\subsubsection{Analisando a questão da isonomia processual}

O problema da isonomia processual costuma ser apontado como grave entrave a uma maior participação do assistente no processo penal. Essa objeção pode ser ilustrada a partir do pensamento de LANZÓN, cujos argumentos, embora se deem no contexto do direito argentino, podem ser aplicados ao processo penal brasileiro.

Referido autor questiona a violação, no combate judicial, da igualdade de armas, quando intervêm, de um lado, o Estado e a vítima, e de outro, o acusado. Cita, como exemplos dessa violação, com base no direito argentino, além da atuação da vítima no processo - hipótese agravada caso tal atuação se dê de modo autônomo em relação ao Ministério Público -, as hipóteses em que o Estado se divide em diversos órgãos persecutores, e a ampliação do conceito de vítima (ofendido) de modo a abranger entes que defendam direitos coletivos ou difusos.

Contra a argumentação de que se poderia proceder a uma unificação dos querellantes sob uma representação única, como consta da interpretação dos arts. 85 e 416, do C.P.P.N., LANZÓN rebate tal representação única, afirmando que essa não evitaria os excessos referidos, pois que "la desigualdad proviene de la intervención de la víctima y/lo dos demás ofendidos como otro centro de interés, sumado al de la persecución penal oficial". 510

Acerca da matéria, faz-se necessária uma incursão, ainda que breve, ao princípio da isonomia e, daí, à par conditio no processo penal. Para tanto, tome-se o pensamento de TUCCI sobre a isonomia. O autor observa que, não obstante a

${ }^{510}$ Conferir argumentação completa do autor: LANZÓN, Román P. La intervención de la víctima en el proceso penal y su derecho a actuar como querellante. In: GUZMÁN, Nicolás. (Coord.). El sistema penal en las sentencias recientes de los órganos interamericanos de protección de los derechos humanos. Buenos Aires: Ad Hoc, 2009, p. 223-250, p. 237-239. 
indeterminação genérica de pessoas, a isonomia (igualdade) constituiria a mesma identidade de situação jurídica em que essas se postam. Assim, a inegável e inevitável desigualdade existente entre os indivíduos deve ser tomada para que se estabeleça a construção desse ideal isonômico, que assegura a todos as mesmas possibilidades e a mesma capacidade de adquirir direitos e de contrair obrigações. ${ }^{511}$

Partindo de tal concepção sobre a isonomia, o autor lança sua própria concepção acerca de isonomia processual. Assim, para TUCCI, referida isonomia processual "reclama que aos sujeitos parciais sejam concedidas as mesmas armas a fim de que, paritariamente tratadas, tenham idênticas chances de reconhecimento, satisfação ou asseguração do direito que constitui o objeto material do processo". 512

No processo penal, não obstante a impossibilidade de definição do Ministério Público e do acusado como partes, ao menos na acepção original do termo - oriundo da processualística civil -, o que enseja a necessidade de uma revisitação do conceito sob as peculiaridades do processo penal, ${ }^{513}$ cabe a indagação: é possível falar-se em isonomia processual?

$A b$ initio, constata-se a disparidade existente entre Ministério Público e acusado. A investigação preliminar, que se dá normalmente por inquérito policial, dá testemunho da desproporcionalidade de meios à disposição do Estado-persecutor (Ministério Público, secundado pela Polícia Judiciária) contra o investigado, ao qual, na hipótese eventual de estar ciente da investigação em curso, apenas se reserva normalmente o papel de aguardar a conclusão das atividades investigatórias, acompanhando, eventualmente, alguns atos específicos; outro fator que atesta essa desigualdade pode ser atribuído à possibilidade de decretação de prisão cautelar contra o acusado, cuja reciprocidade em relação ao Ministério Público seria, por óbvio, inimaginável. ${ }^{514}$ Esse

\footnotetext{
511 “A possibilidade e a capacidade de adquirir direitos e de contrair obrigações, peculiares à situação jurídica em que se postam os interessados, devem ser, portanto, as mesmas para todas as pessoas que nela, equivalentemente se encontrem. Como tivemos a oportunidade de salientar, a esse respeito, isso significa que 'não obstante a indeterminação genérica de pessoas, que a qualifica, a igualdade repousa na identidade de situação jurídica em que todas elas se postam. Assim também que proporcional deve ser a verdadeira igualdade. Tem de considerar as diversidades existentes entre os homens, posto que o tratamento igual a pessoas que se encontrem em situações diferentes constituiria autêntica iniquidade'. Com efeito, em paridade de situações, ninguém deve ser tratado excepcionalmente. Todavia, evidenciada a desigualdade entre as pessoas - seja, físicas, sejam jurídicas ou formais -, deverão ser consideradas as condições desiguais para que possa haver igualdade." (destaques do autor). (TUCCI, Rogério Lauria. Direitos e garantias individuais no processo penal brasileiro. 3. ed. rev. atual. amp. São Paulo: Revista dos Tribunais, 2009, p. 120).

512 TUCCI, Rogério Lauria. Direitos e garantias individuais no processo penal brasileiro. 3. ed. rev. atual. amp. São Paulo: Revista dos Tribunais, 2009, p. 122.

${ }^{513}$ Cf. item 5.2.1.

514 “A desigualdade entre agentes da persecução penal e indiciado ou acusado não tem como ser evitada. A partir do momento em que um sujeito parcial está sendo preso cautelarmente, ou pode vir a estar, perde-se de
} 
panorama bem atesta o incontestável quadro de desigualdade que marca o processo penal.

A despeito de tamanha desproporcionalidade entre Ministério Público e acusado, convém registrar que o próprio ordenamento jurídico oferece meios para se tentar estabelecer um equilíbrio entre tais sujeitos. Assim, é que princípios como o contraditório, o devido processo legal, a ampla defesa, a presunção de inocência - que compreende duas acepções $^{515}$ : regra de julgamento ${ }^{516}$ e regra de tratamento $^{517}$-, a garantia jurídica do habeas corpus, o manejo exclusivo da revisão criminal etc., põem-se como decisivo contrapeso ao desequilíbrio inicial. ${ }^{518}$

Uma vez analisado o problema da isonomia entre Ministério Público e acusado, passa-se a questionar se a acolhida da vítima sob as vestes de assistente, dotado de faculdades processuais cada vez mais incisivas, não custaria ao processo penal um agravamento nessa já delicada relação de equilíbrio entre os sujeitos parciais.

vista qualquer perspectiva de igualdade entre ele e o agente da persecução. Não há ficção que sustente a igualdade entre acusado preso cautelarmente e o Ministério Público." (COSTA, Paula Bajer Fernandes Martins da. Igualdade no direito processual penal brasileiro. São Paulo: Revista dos Tribunais, 2001, p. 95).

${ }^{515}$ Essas acepções, em número de duas, pelo menos, são identificadas por ILLUMINATI: "Si rittiene attualmente che la presunzione d'innocenza abbia um significato (almeno) dúplice: regola di trattamento dell'imputato; regola di giudicio". (ILLUMINATI, Giulio. La presunzione d'innocenza dell'imputato. Bologna: Zanichelli, 1984, p. 15).

${ }^{516}$ A regra de julgamento significa dizer que se a pessoa, a priori, deve ser considerada inocente, incumbirá ao acusador propor e produzir provas que lhe atestem a culpabilidade, e não àquela a demonstração de sua inocência. Assim, no processo penal, o ônus da prova compete exclusivamente à acusação, que deverá comprovar suas alegações perante o Estado-juiz, sendo assegurados ao acusado os princípios do contraditório e da ampla defesa. Em tal sentido, BADARÓ chega a sustentar, atento ao alcance do princípio da Presunção de Inocência, que o ônus probatório do Ministério Público compreende não apenas a comprovação da existência dos fatos constitutivos do ius puniendi estatal, mas também a comprovação da efetiva ausência dos fatos impeditivos a tal direito: "O ônus da prova incumbe inteiramente ao Ministério Público, que deverá provar a presença de todos os elementos necessários para o acolhimento da pretensão punitiva. Para usar a regra do processo civil, ao Ministério Público caberá não só o ônus da prova da existência do fato constitutivo do direito de punir, como também da inexistência dos fatos impeditivos de tal direito". (BADARÓ, Gustavo Henrique Righi Ivahy. Ônus da prova no processo penal. São Paulo: Editora Revista dos Tribunais, 2003, p. 296-297).

${ }^{517}$ A regra de tratamento assegura que o status innocentiae exige um tratamento efetivo do acusado como inocente, quer no decorrer do desenvolvimento do processo penal propriamente dito, quer em momento prévio, no âmbito da investigação preliminar. Qualquer exteriorização quanto à culpabilidade do acusado (antes de eventual condenação definitiva) ou que venha a incutir uma indevida influência em tal sentido, não somente deve ser evitada como prontamente rechaçada. Neste ponto, cabe destacar o especial papel da mídia nesse sentido: "Nos meios de comunicação, não se distingue entre suspeito e condenado. Ainda que a imprensa pretenda diferenciá-los, a maneira como divulga os fatos criminosos e expõe os seus possíveis autores leva à abolição de um princípio lógico, do qual se originou o princípio da presunção de inocência.". (VIEIRA, Ana Lúcia Menezes. Processo penal e mídia. São Paulo: Revista dos Tribunais, 2003, p.168).

${ }^{518}$ Para HAMILTON, a mitigação do desequilíbrio em favor do acusado se mostra tamanha que gera uma tendência de desequilíbrio em sentido inverso, contrária aos interesses da acusação: "No processo penal tal colocação sofre séria mitigação, pois a defesa é privilegiada pela lei em diversas passagens em homenagem ao favor rei. Além da manifesta desigualdade imposta pelo direito positivo em detrimento da acusação, a interpretação doutrinária e jurisprudencial majoritária, da mesma forma, segue orientação favorável à defesa nas questões não expressamente previstas na lei, ensejadoras, por tal razão, de polêmica doutrinária ou de disputa jurisprudencial". (HAMILTON, Sérgio Demoro. Temas de processo penal. Rio de Janeiro: Lumen Juris, 1998, p. 196). 
Na verdade, a participação da vítima - como advertiu LANZÓN - acrescenta outro centro de interesses no processo penal. Eventual desequilíbrio daí decorrente, todavia, está atrelado a um erro de perspectiva. De fato, segundo a tradicional perspectiva do processo penal, o confronto limita-se a dois contendores: Ministério Público e acusado. Sob essa ótica, uma intervenção processual da vítima mais atuante e decisiva causaria grandes estragos ao pretendido equilíbrio.

O que se propõe, todavia, é que à vítima, protagonista quando da ocorrência da infração penal, deva ser assegurado, também, o protagonismo no processo que lhe é subsequente. Assim, provoca-se uma mudança de perspectiva. O processo penal, que antes abrigava somente dois polos de interesses (Ministério Público e acusado), agora passa a compreender três polos de interesses, acrescendo-se o da vítima-assistente, que não se confunde em definitivo com o polo representado pelo Ministério Público, haja vista a diversidade dos interesses que os movem. ${ }^{519}$

Se admitidos como necessários esses três polos, sob essa nova perspectiva, o conceito de equilíbrio no processo penal passa a ser outro, tomando-se por base, agora, a atuação de três sujeitos distintos. Os diversos princípios e regras processuais que incidiam em prol do equilíbrio no confronto entre Ministério Público e acusado, deverão continuar a incidir também quanto a eventual confronto entre assistente e acusado, vedando-se, agora, também ao assistente, contar com armas jurídicas que também não sejam disponibilizadas ao acusado.

A princípio, então, o ingresso da vítima no processo penal e a atribuição crescente de faculdades processuais que se lhe propõe, não ensejam desequilíbrio no processo. Entretanto, deve-se atentar que uma ampliação excessiva do conceito de vítima, como por exemplo, tal qual se encontra na Declaração dos Princípios Básicos de Justiça Relativos às Vítimas da Criminalidade e de Abuso de Poder, da ONU (Resolução 40/34, de 29.11.1985), ${ }^{520}$ de matriz vitimológica, e o reconhecimento de sua legitimidade perante o

519 O Ministério Público atua como defensor dos interesses sociais, no que pode pugnar por interesses diversos como a segurança pública e mesmo pelo direito à liberdade, hipótese na qual poderá, inclusive, pedir a absolvição do acusado; já a vítima tem os interesses voltados à sua pessoa e não à coletividade, interesse tais que podem ser marcados pela indisponibilidade (tratamento digno, por exemplo) ou pela disponibilidade (direito à reparação patrimonial, por exemplo).

520 "1. Entendem-se por "vítimas" as pessoas que, individual ou coletivamente, tenham sofrido um prejuízo, nomeadamente um atentado à sua integridade física ou mental, um sofrimento de ordem moral, uma perda material, ou um grave atentado aos seus direitos fundamentais, como conseqüência de atos ou de omissões violadores das leis penais em vigor num Estado membro, incluindo as que proíbem o abuso de poder. 2. Uma pessoa pode ser considerada como "vítima", no quadro da presente Declaração, quer o autor seja ou não identificado, preso, processado ou declarado culpado, e quaisquer que sejam os laços de parentesco deste com a vítima. O termo "vítima" inclui também, conforme o caso, a família próxima ou as pessoas a cargo da 
processo penal poderiam converter o polo de interesses das vítimas em um superpolo, redundando em grande desproporção de forças no processo penal.

Assim, é que o próprio conceito de vítima, em sentido jurídico-processual penal, ao menos para os fins de participação no processo, ${ }^{521}$ não pode corresponder exatamente ao amplo conceito vitimológico enunciado na Declaração da ONU, propondose, neste trabalho, uma concepção processual de vítima que possa contemplar tanto a figura do sujeito passivo da infração penal/ofendido principal ou secundário, quanto a figura do sujeito prejudicado ${ }^{522}$ - dotando-se a ambos de legitimidade para atuação no processo penal - valendo-se, assim, de uma noção de imediatidade que impeça o elastecimento em demasia do conceito para se encaixarem vítimas indiretas.

Firmada essa opção conceitual, a legitimidade para atuar como assistente deve seguir as regras vigentes, de cunho mais restritivo, a saber: a legitimidade, a princípio, cabe ao ofendido, e no caso de sua morte ou ausência, a seus familiares mais próximos (cônjuge/convivente, ascendente, descente e irmãos), dotados que são de legitimidade supletiva. $^{523}$

Em se tratando de crimes de vítimas difusas, não se podendo determinar, portanto, vítimas específicas, nada impede que a legislação permita a habilitação de uma única entidade (pública ou privada) que atue em defesa dos interesses jurídico-penais violados.

De qualquer forma, a Lei deve estipular criteriosamente as hipóteses em que tal habilitação se faça possível, bem como os requisitos para a habilitação da entidade, podendo servir, como inspiração, os requisitos estabelecidos no processo penal italiano (art. 91, do c.p.p.), a saber, a ausência de finalidade de lucro, a constituição legal prévia à prática da infração penal e a pertinência entre as finalidades da associação e a defesa do interesse jurídico-penal violado. ${ }^{524}$

vítima direta e as pessoas que tenham sofrido um prejuízo ao intervirem para prestar assistência às vítimas em situação de carência ou para impedir a vitimização. 3. As disposições da presente seção aplicam-se a todos, sem distinção alguma, nomeadamente de raça, cor, sexo, idade, língua, religião, nacionalidade, opiniões políticas ou outras, crenças ou práticas culturais, situação econômica, nascimento ou situação familiar, origem étnica ou social ou capacidade física".

${ }_{521}$ Nada impede que se adote um conceito mais amplo de vítima para fins, por exemplo, do direito à proteção, sob a modalidade de amparo econômico pelo Estado, instituindo-se um fundo público em prol das vítimas de infração penal, conforme o conceito trazido pela ONU.

${ }_{522}^{52} \mathrm{Cf}$. item 2.4.1.

${ }^{523}$ Cf. item 5.2.3.

524 "Gli enti e le associazioni senza scopo di lucro ai quali, anteriormente alla commissione del fatto per cui si procede, sono state riconosciute, in forza di legge, finalità di tutela degli interessi lesi dal reato, possono esercitare, in ogni stato e grado del procedimento, i diritti e le facoltà attribuiti alla persona offesa dal reato". 


\subsubsection{Analisando o monopólio da ação penal de iniciativa pública}

Outro tema que merece abordagem ao se analisar a participação da vítima no processo penal, sob a modalidade de assistente, consiste na possível ofensa ao monopólio estatal sobre a ação penal de iniciativa pública, previsto no art. 129 , inciso I, da Constituição Federal de $1988 .{ }^{525}$

Nesse ponto, dois direitos podem ser destacados: o direito da vítima à participação como assistente, decorrente do direito fundamental à tutela jurisdicional efetiva, que por sua vez, tem por base principiológica, a Dignidade da Pessoa Humana; doutra parte, o direito do acusado a uma acusação por órgão estatal isento, o Ministério Público.

O direito por último referido acima ganha destaque nas lições de OLIVEIRA, que o afirma como garantia individual do acusado à "reserva do juízo de propositura da ação penal a um órgão estatal, absolutamente imparcial em relação ao fato e, para isso, dotado de prerrogativas institucionais que o assemelham à magistratura". ${ }^{526}$ Evita-se, assim, a propositura da ação penal de modo temerário ou mesmo com base em sentimento de passionalidade, em tese, mais próximo da vítima, e mais distante do próprio perfil de

\footnotetext{
${ }^{525}$ A própria constitucionalidade da assistência em processo penal chega a ser questionada: "[...] poder-se-ia questionar ainda a (in)constitucionalidade do instituto, na medida em que o art. 129, I, da Constituição é categórico ao afirmar que compete ao Ministério Público promover 'privativamente' a ação penal pública na forma da lei. A única exceção, também constitucional, ao pode privativo de promoção da ação penal pública, está no art. $5^{\circ}$, LIX, na chamada ação penal privada subsidiária (ou substitutiva) da pública [...]. Logo, como não é possível assistente da acusação na ação penal de iniciativa privada (pois ele é o autor principal) e, na pública, a promoção é de atribuição 'privativa' do Ministério Público, não estaria recepcionada pelo texto constitucional a figura do assistente da acusação, sendo ilegítima sua intervenção. Nesse sentido, também se posiciona POLASTRI LIMA, afirmando que 'ao dispor a Lei Maior que a promoção da ação penal pública é privativa do Ministério Público, para nós, derrogado estaria o Código de Processo Penal no que tange aos dispositivos atinentes à assistência ao parquet, face à manifesta incompatibilidade". (LOPES JÚNIOR, Aury. Direito processual penal e sua conformidade constitucional. 5. ed. rev. atual. Rio de Janeiro: Lumen Juris, 2010 , v. 1, p. 44). OLIVEIRA rechaça tal objeção, buscando fundamento em outros dispositivos de igual natureza constitucional que autorizam a intervenção da vítima na ação penal de iniciativa pública: a necessidade de controle da atuação dos órgãos estatais (art. $5^{\circ}$., inciso LIX, da C.F.), a inafastabilidade do Judiciário na tutela de direitos subjetivos individuais (art. $5^{\circ}$, inciso XXXV, da C.F.), o direito subjetivo à reparação do dano causado pela infração penal (art. $5^{\circ}$, inciso XLV, da Lei Maior), e, por fim, a exigência da unidade da jurisdição, a ser controlada pela existência de subordinação entre as instâncias". (OLIVEIRA, Eugênio Pacelli. Processo e hermenêutica na tutela penal dos direitos fundamentais. 2. ed. rev. atual. Rio de Janeiro: Lumen Juris: 2009, p. 107).

${ }^{526}$ OLIVEIRA, Eugênio Pacelli. Processo e hermenêutica na tutela penal dos direitos fundamentais. 2. ed. rev. atual. Rio de Janeiro: Lumen Juris: 2009, p. 37. Para uma análise mais aprofundada sobre tal direito, cf. OLIVEIRA, Eugênio Pacelli. Processo e hermenêutica na tutela penal dos direitos fundamentais. 2. ed. rev. atual. Rio de Janeiro: Lumen Juris: 2009, p. 11-63.
} 
um órgão acusatório oficial, como o é o Ministério Público. ${ }^{527}$

Visando a uma solução quanto à colidência desses dois direitos (o direito da vítima à participação como assistente $v s$. o direito do acusado a uma acusação por um órgão estatal e isento), propõe-se uma nova leitura do art. 129, inciso I, da Constituição Federal, de modo a permitir uma atuação autônoma do assistente - o que consiste em verdadeira exigência do direito à tutela jurisdicional efetiva - sem que seja desconsiderada, por outro lado, a privatividade da ação penal pública conferida ao Ministério Público pelo constituinte de 1988.

Antes, porém, mostra-se imprescindível examinar o que venha a ser o significado da promoção da ação penal pública, privativamente atribuída ao Ministério Público pela Constituição de $1988,{ }^{528}$ análise essa em que as tradicionais categorias da processualística civil têm relativa serventia, carecendo de uma nova perspectivação.

Como é sabido, ocorrida uma infração penal, surge, para o Estado, o ius puniendi ou uma pretensão punitiva, assim entendida por BADARÓ como "o poder do Estado de exigir de quem comete o delito a submissão à sanção penal". ${ }^{529}$ Sobre tal pretensão, diferentemente do que ocorre com a pretensão civilística, vige a ideia de jurisdição necessária, ou seja, sua concretização pressupõe um devido processo legal prévio.

Esse processo penal, para que seja deflagrado, pressupõe a provocação da jurisdição pelo exercício da ação penal (de tutela condenatória), que para TUCCI, se traduz em uma "ação correspondente ao exercício de direito à jurisdição criminal". 530

A ação penal exercida veiculará uma pretensão ${ }^{531}$, denominada de pretensão acusatória ou pretensão processual penal ${ }^{532}$, que consiste em uma "declaração petitória de

527 Apropriados, neste ponto, os comentários de CALAMANDREI: "Entre todos os cargos judiciários, o mais
difícil, segundo me parece, é o do Ministério Público. Este, como sustentáculo da acusação, devia ser tão
parcial como uma advogado; como guarda inflexível da lei, devia ser tão imparcial como um juiz. Advogado
sem paixão, juiz sem imparcialidade, tal é o absurdo psicológico no qual o Ministério Público, se não adquirir
o sentido do equilíbrio, se arrisca, momento a momento, a perder, por amor da sinceridade, a generosa
combatividade do defensor ou, por amor da polêmica a objectividade sem paixão do magistrado".
(CALAMANDREI, Piero. Eles, os juízes, vistos por nós, os advogados. 7. ed. Lisboa: Clássica, 1985).
528 “Art. 129. São funções institucionais do Ministério Público: I - promover, privativamente, a ação penal
pública, na forma da lei."
529 BADARÓ, Gustavo Henrique Righi Ivahy. Correlação entre acusação e sentença. 2. ed. São Paulo:
Revista dos Tribunais, 2009 , p. 68 .
530 TUCCI, Rogério Lauria. Teoria do direito processual: jurisdição, ação e processo penal (estudo
sistemático). São Paulo: Revista dos Tribunais, 2002 , p.80.
531 O termo pretensão, em processo penal, tem concepção diversa da que apresenta no processo civil, não se
confundindo com esta. Segundo BADARÓ, NUVOLONE, em sua obra Contributto alla teoria della
sentenza istruttoria penale, “[...] entende que no processo penal não há uma pretensão. O autor parte da
premissa de que toda pretensão implica, como correlativo lógico, uma resistência, e se no processo penal não
há lide, justamente por ser irrelevante tal resistência, conclui que no processo penal não há pretensão". 
que existe o direito potestativo de acusar e que procede a aplicação do poder punitivo estatal". 533 Essa pretensão não se confunde com a pretensão punitiva, de natureza material. $^{534}$

Pois bem, se a pretensão punitiva (pretensão material) é de inquestionável exclusividade do Estado, a pretensão acusatória (pretensão processual penal), porém, não precisa sê-lo necessariamente.

De fato, em face da Constituição de 1988, a pretensão acusatória, poderá ser trazida ao Estado-juiz, via ação, pelo Ministério Público ou pelo particular. Isso porque o próprio constituinte trouxe a hipótese de ação penal de iniciativa privada subsidiária (art. $5^{\circ}$, inciso LIX), o que demonstra a inexistência de monopólio estatal sobre a dedução da pretensão acusatória, ou seja, sobre o exercício da ação penal (gênero).

Pressupondo-se, dessarte, que a pretensão acusatória não é de exclusividade do Estado, o legislador pode instituir hipóteses tanto de ações penais de iniciativa pública, quanto hipóteses de ações penais de iniciativa privada - não somente em caráter subsidiário -, as quais embora atualmente sejam em menor número, ainda se encontram presentes na legislação brasileira, sendo que nas primeiras, incumbiria ao Ministério Público, com exclusividade, a dedução da pretensão acusatória, e, nas últimas, a dedução caberia ao próprio ofendido. Daí dizer-se que a ação penal de iniciativa pública é privativa do Ministério Público.

Aí é que se sugere uma interpretação de cunho mais vitimológico. Se a

(BADARÓ, Gustavo Henrique Righi Ivahy. Correlação entre acusação e sentença. 2. ed. São Paulo: Revista dos Tribunais, 2009, p. 73).

532 O conceito de pretensão acusatória, que pode ser conferido em LOPES JÚNIOR, Aury. Direito processual penal e sua conformidade constitucional. 5. ed. rev. atual. Rio de Janeiro: Lumen Juris, 2010, v. 1, p. 85-113, corresponde exatamente ao conceito de pretensão processual penal, de BADARÓ, em: BADARÓ, Gustavo Henrique Righi Ivahy. Correlação entre acusação e sentença. 2. ed. São Paulo: Revista dos Tribunais, 2009, p. 61-71.

${ }^{533}$ LOPES JÚNIOR, Aury. Direito processual penal e sua conformidade constitucional. 5. ed. rev. atual. Rio de Janeiro: Lumen Juris, 2010, v. 1, p. 97. Prossegue o autor, afirmando que essa pretensão "não é um direito subjetivo, mas uma consequência jurídica de um estado de fato (lesão ao bem jurídico) ou um estado de fato com consequências jurídicas. Mais, é um direito potestativo, o poder de proceder contra alguém diante da existência de fumus comissi delicti". (LOPES JÚNIOR, Aury. Direito processual penal e sua conformidade constitucional. 5. ed. rev. atual. Rio de Janeiro: Lumen Juris, 2010, v. 1, p. 97).

${ }^{534}$ Sobre a pretensão punitiva: "Essa pretensão material, anterior e extraprocessual, irá ingressar no processo, sendo a razão ou motivo do mesmo. No processo, porém, o que existe é a pretensão processual, embora esta apresente como parte de seu fundamento os elementos que compunham a pretensão material. Definida a pretensão punitiva como pretensão material, deve-se destacar que a distinção entre a pretensão material e a pretensão processual não é mera questão terminológica. Não é também um mesmo fenômeno visto em momentos diversos antes e durante o processo. [...]. A pretensão processual é aquela veiculada em juízo, através do exercício da ação, e terá existência independentemente do direito material que fundamenta o pedido do autor. Sem a pretensão processual não existiria o processo. Essa pretensão, contudo, no final do processo, poderá ser acolhida ou rejeitada, mas nunca será uma pretensão inexistente”. (BADARÓ, Gustavo Henrique Righi Ivahy. Correlação entre acusação e sentença. 2. ed. São Paulo: Revista dos Tribunais, 2009, p. 69-70). 
propositura da ação penal de iniciativa pública é reservada privativamente ao Ministério Público, conforme dispõe a Constituição Federal, o exercício subsequente dos atos processuais não precisa ser também exclusivo daquele órgão público, podendo ser desempenhado também pela vítima, que passa a integrar o processo como sujeito processual, ocupando polo distinto de interesses.

Desse modo, em sede de ações penais de iniciativa pública, a privatividade estatal restringe-se à dedução da pretensão acusatória em juízo, de modo que após tal dedução, o exercício das faculdades processuais possa ser garantido tanto ao Ministério Público quanto à vítima, os quais poderão agir com independência entre si, não exigindo a norma constitucional uma atuação da vítima em subordinação ao Ministério Público.

As benesses de tal interpretação mostram-se indiscutíveis. Por um lado, resta preservada, em favor do acusado, a garantia de que apenas o Ministério Público (órgão estatal imparcial e independente) poderá deduzir a pretensão acusatória na ação penal de iniciativa pública. Ou seja, somente a tal órgão estatal competirá formular a imputação penal, que consiste na "afirmação do fato que se atribui ao sujeito, a afirmação de um tipo penal e a afirmação da conformidade do fato com o tipo penal". 535 Somente o Ministério Público poderá, assim, delinear os contornos da acusação, originariamente ou por aditamentos posteriores, à qual estará jungida toda a atuação processual dos demais sujeitos do processo (juiz, acusado e assistente), o que não deixa de ser precioso para o acusado.

Quanto à vítima, também pode ser apontada uma vantagem manifesta, que consiste na possibilidade, não somente de uma maior e mais incisiva atuação da sua parte, mas de uma atuação verdadeiramente independente da atividade processual do Ministério Público, o que constitui fator de inquestionável relevância para a eliminação da vitimização secundária no processo penal.

Assim, em termos bem categóricos, nas ações penais de iniciativa pública, o Ministério Público seria o senhor da dedução da pretensão acusatória em juízo. Uma vez deduzida essa pretensão, não existiriam óbices constitucionais para que, tanto o Estado quanto o assistente, em atuações independentes entre si, possam praticar atos visando ao acolhimento de tal pretensão pelo juízo penal, em sendo o caso. ${ }^{536}$

\footnotetext{
535 BADARÓ, Gustavo Henrique Righi Ivahy. Correlação entre acusação e sentença. 2. ed. São Paulo: Revista dos Tribunais, 2009, p. 74. Sobre a imputação e sua importância no processo penal, como objeto da pretensão processual penal, cf. BADARÓ, Gustavo Henrique Righi Ivahy. Correlação entre acusação e sentença. 2. ed. São Paulo: Revista dos Tribunais, 2009, p. 71-84.

${ }_{536}$ Nada impede, é claro, que Ministério Público ou vítima venham a postular a absolvição do acusado.
} 
Na verdade, em um processo penal conformado constitucionalmente, para além de se entender pela inexistência de óbices para uma atuação autônoma do assistente, faz-se necessário conceber que tal atuação constitui verdadeira exigência do Princípio da Dignidade da Pessoa Humana, irradiado no universo jurídico das vítimas de infração penal.

Essa ideia de autonomia não se encontra tão distante de concretizar-se. A jurisprudência do Supremo Tribunal Federal (STF), quando do julgamento do HC n. 102085/RS, ao enunciar na ementa do respectivo acórdão que "[...] a manifestação do promotor de justiça, em alegações finais, pela absolvição da Paciente e, em seu parecer, pelo não conhecimento do recurso, não altera nem anula o direito da assistente de acusação recorrer da sentença absolutória [...]", ${ }^{537}$ enseja o reconhecimento de certo grau de autonomia ao assistente em relação à atividade do Ministério Público, o que pode constituir um significativo passo em direção à adoção do entendimento ora defendido.

De fato, como já visto, o assistente tem legitimidade para recorrer de algumas decisões contra as quais o Ministério Público não interponha recurso no prazo legal. Essa atuação recursal supletiva do assistente teria por objetivo suprir a inércia da atuação ministerial, à semelhança do que ocorre na ação penal de iniciativa privada subsidiária. ${ }^{538}$

Ocorre que, a vingar tal paralelismo (atuação recursal supletiva/ação subsidiária), ao pedir a absolvição nas alegações finais, e sendo tal pedido acolhido pelo juiz, não se caracterizaria inércia do Ministério Público quanto à interposição de recurso. $\mathrm{Na}$ verdade, nas alegações finais, estaria referido órgão manifestando suas razões para não interpor o recurso, abrindo mão expressamente da própria pretensão acusatória. Essa postura equivaleria, mutatis mutandi, à promoção do arquivamento de inquérito policial

\footnotetext{
${ }^{537}$ HC 102085 / RS - RIO GRANDE DO SUL Relator(a): Min. CÁRMEN LÚCIA Julgamento: 10/06/2010 Órgão Julgador: Tribunal Pleno Publicação DJe-159 DIVULG 26-08-2010 PUBLIC 27-08-2010 Relatora Ministra Carmen Lúcia. "EMENTA: HABEAS CORPUS. CONSTITUCIONAL. PROCESSO PENAL. ESTELIONATO. ALEGAÇÃO DE ILEGITIMIDADE DA ASSISTENTE DE ACUSAÇ̃̃O PARA RECORRER DA SENTENÇA PENAL ABSOLUTÓRIA. IMPROCEDÊNCIA. AUSÊNCIA DE RECURSO DO MINISTÉRIO PÚBLICO. IRRELEVÂNCIA DO PARECER MINISTERIAL DE PRIMEIRA INSTÂNCIA PELO NÃO CONHECIMENTO DO RECURSO. 1. A assistente de acusação tem legitimidade para recorrer da decisão que absolve o réu nos casos em que o Ministério Público não interpõe recurso. 2. Aplicação da Súmula 210 do Supremo Tribunal Federal: "O assistente do Ministério Público pode recorrer, inclusive extraordinariamente, na ação penal, nos casos dos arts. 584, $\S 1^{\circ}$, e 598 do Código de Processo Penal". 3. A manifestação do promotor de justiça, em alegações finais, pela absolvição da Paciente e, em seu parecer, pelo não conhecimento do recurso não altera nem anula o direito da assistente de acusação recorrer da sentença absolutória. 4. Ordem denegada" (destaques nossos). Disponível em: $<$ http://www.stf.jus.br/portal/processo/verProcessoDetalhe. asp?incidente $=3816006>$. Acesso em: 13 jan. 2012.

538 " OO ofendido, ao recorrer, esteja ou não habilitado como assistente, supre a inércia do Ministério Público e, à semelhança de sua atuação ao oferecer queixa subsidiária, figura como substituto processual, defendendo em seu nome interesse do Estado, em que seja aplicada a lei penal e punido o réu". (FERNANDES, Antônio Scarance. O papel da vítima no processo criminal. São Paulo: Malheiros, 1995, p. 147).
} 
acolhida pelo juiz, que afasta a ideia de inércia do Ministério Público, conforme o entendimento majoritário, eliminando a possibilidade de exercício, pelo ofendido, da ação penal de iniciativa privada subsidiária. ${ }^{539}$

Embora não tenham se detido mais profundamente sobre a configuração ou não da inércia ministerial nessa situação - não obstante algumas referências levantadas pelo Ministro Marco Aurélio, que questionava a transmutação, no caso, da ação penal de iniciativa pública em ação penal de iniciativa privada -, os membros do STF, em sua maioria, optaram por reconhecer o direito recursal do assistente - ainda que supletivo -, independentemente da postura do Ministério Público. ${ }^{540}$

Essa decisão da Suprema Corte brasileira, embora não tenha descido à profundidade e ensejado desdobramentos posteriores acerca da autonomia do assistente, como se verificou no caso Santillán, apreciado pela Corte Suprema de Justicia de la Nación, da Argentina, ${ }^{541}$ pode abrir caminho para o reconhecimento de alguma autonomia do assistente em relação à atuação do Ministério Público.

Em verdade, a questão da autonomia do assistente, cumpre enfatizar, antes de cuidar-se de questão de técnica jurídica, resulta, na verdade, de escolhas axiológicas, levadas a cabo pela Política Criminal: "La posibilidad o no de que la víctima participe activamente en el proceso penal no es un problema nuevo, pero sí actual. Antes que un conflito técnico-jurídico se trata de uma cuestión netamente ideológica o de política criminal". 542

\subsubsection{O protagonismo da vítima: apontamentos sobre modificações na conformação do assistente no processo penal brasileiro}

\footnotetext{
539 Situação outra seria aquela em que o Ministério Público pedisse a condenação do acusado, o juiz o absolvesse, e aquele não interpusesse recurso. A inércia, aí, seria evidente, pois que o Ministério Público, em seu último pronunciamento processual, ainda sustentava o acolhimento da pretensão acusatória.

${ }^{540}$ Cf. a íntegra do acórdão do HABEAS CORPUS n. 102085/RS.

${ }^{541}$ Cf. LANZÓN, Román P. La intervención de la víctima en el proceso penal y su derecho a actuar como querellante. In: GUZMÁN, Nicolás. (Coord.). El sistema penal en las sentencias recientes de los órganos interamericanos de protección de los derechos humanos. Buenos Aires: Ad Hoc, 2009, p. 223-250, p. 227-234.

542 "La posibilidad o no de que la víctima participe activamente en el proceso penal no es un problema nuevo, pero si actual. Antes que un conflito técnico-jurídico se trata de uma cuestión netamente ideológica o de política criminal." (LANZÓN, Román P. La intervención de la víctima en el proceso penal y su derecho a actuar como querellante. In: GUZMÁN, Nicolás. (Coord.). El sistema penal en las sentencias recientes de los órganos interamericanos de protección de los derechos humanos. Buenos Aires: Ad Hoc, 2009, p. 223-250, p. 224).
} 
Tem-se explanado aqui que a figura do assistente no atual processo penal brasileiro encontra-se marcada pelo signo da restrição, que lhe impõe um status inferior em relação aos demais sujeitos processuais, o que se traduz em severas limitações às suas faculdades processuais, destacando-se a ausência de direito à prova e sua atuação recursal pontual e supletiva.

$\mathrm{Na}$ verdade, a estratégia do ordenamento jurídico brasileiro em relação à participação da vítima no processo penal, no que não difere de muitos outros ordenamentos, parece ser de não a afastar de todo, evitando-se seu completo olvidamento, mas de aproximá-la, desde que lhe seja reconhecida sua inferioridade processual.

Esse tratamento desigual em relação à vítima resulta ainda do processo histórico de neutralização, que faz ainda parecer que aquela, fora das hipóteses em que constitua fonte de prova, seja vista como um elemento estranho no âmbito do processo penal, bem como da opinião pré-concebida e disseminada de que o único ou o principal interesse que move as vítimas de infração penal seja o desejo de vingança, o que colocaria em risco o equilíbrio e a serenidade que devem marcar o processo penal.

Em relação ao primeiro aspecto, cabe destacar que a concepção da vítima exclusivamente como fonte de prova tem sido questionada em razão do desenvolvimento do movimento vitimológico, que tem suscitado o reconhecimento de novos papéis da vítima em relação à jurisdição penal.

Trata-se mesmo da quebra de um paradigma, mostrando-se escusável a reminiscência de postulados anteriores em razão da ainda recente gênese do movimento de redescoberta da vítima.

Da mesma forma, a persistência da opinião pré-concebida de que a vítima tenha o exclusivo ou principal interesse na vingança em relação ao autor da infração penal, ameaçando o processo penal, também pode ser creditada como reminiscência do processo histórico de neutralização.

Quanto a essa visão, pode-se afirmar que não pode ser objeto de generalização. De fato, vítimas há que possam pretender a pura e simples vingança, todavia, não se deve esquecer a existência de vítimas que confiam no aparelho estatal e querem deste receber uma resposta justa. Mesmo que abstraídas quaisquer considerações axiológicas quanto à concepção do que seja justiça, trata-se, enfim, de um argumento de cunho eminentemente subjetivo, desprovido de comprovação científica, e que não pode, por si, afastar a participação das vítimas no processo penal. 
Ademais, ainda que a vítima ingresse na esfera do processo penal, movida exclusivamente pelo simples interesse de vingança, trata-se apenas de um dos sujeitos processuais, um dos polos de interesse presentes no processo.

A necessária existência de outros polos - um centrado na sociedade, representada pelo Ministério Público, outro centrado no próprio acusado -, a atuação de um órgão julgador imparcial e a aplicação do princípio do contraditório e de seus consectários, mostram-se suficientes para preservar o equilíbrio no processo penal, quebrando-se, assim, as reservas quanto a uma maior participação da vítima no processo penal.

Cabe registrar que esse tratamento de cominuição dos direitos, acolhendo a vítima, mas em situação de inferioridade, dispensado pelo ordenamento jurídico brasileiro, pode ensejar, assim como o completo olvidamento da vítima, a já referida vitimização secundária, tornando as instâncias de controle penal co-opressivas em relação à vítima da infração penal.

Na verdade, é chegada a hora de, aplicando-se o Princípio da Dignidade Humana, que irradia seus efeitos não somente em relação ao acusado, mas também em relação à vítima, alçar esta à condição de protagonista do processo penal.

De fato, a infração penal envolve necessariamente três sujeitos: o ofensor, também denominado de autor ${ }^{543}$ ou vitimário, ${ }^{544}$ a sociedade e a(s) vítima(s), ${ }^{545}$ cada qual representando um vetor distinto: liberdade, ordem e solidariedade, ${ }^{546}$ vetores esses que não

\footnotetext{
${ }^{543}$ A respeito da denominação de ofensor/autor, em razão do princípio da presunção de inocência, seria mais adequada a expressão suposto ofensor/autor, o que acarreta igualmente a maior adequação da expressão suposta vítima. Porém, por uma questão de simplificação terminológica, opta-se pelos termos autor e vítima, simplesmente, ficando, desde já, efetuada a devida ressalva; faz-se também a opção de evitar o termo delinquente, que embora não mereça reproche do ponto de vista técnico, traz em si uma forte conotação pejorativa no Brasil.

${ }^{544} \mathrm{O}$ termo vitimário é de gênese vitimológica, que se contrapõe a termos tradicionais como o delinquente, trazendo novas perspectivas para tal sujeito: "Ahora, con el progreso de la ciencia y de la cultura emerge, cada día con más distinción, una nueva figura, una nueva construcción social, el 'victimario', en el lugar que antes ocupaba el delincuente. Ese progreso enseña al Juez que no es Dios y no puede juzgar y condenar al hombre, que sólo puede juzgar sus actos Buenos o malos. Que sólo puede conocer la imputación objetiva y subjetiva de lacto delictivo (pero no del autor). Hoy, al victimario no le vemos como ayer veíamos al delincuente; hoy le vemos en cuanto autor de un daño a otra u otras personas. [...]". (BERISTAIN IPIÑA, Antonio. Derecho penal, criminología y victimología. Curitiba: Juruá, 2007, p. 44).

${ }^{545}$ Todo delito acarreta vítimas. Nos chamados delitos sem vítima, as vítimas existem, embora não sejam individualizadas de pronto. Cuida-se, na verdade, de delitos de vítimas difusas. A respeito, cf. MANZANERA, Luis Rodriguez. Victimología. 12. ed. Cidade do México: Porrúa, 2010, p. 77-81.

${ }^{546}$ Sobre a existência de tais vetores: "Quando pensamos o processo penal, pensamo-lo à luz de dois vectores essenciais> a ordem e a liberdade. [...]. Todavia, quando pensamos a justiça de uma forma mais global, talvez devamos concluir que ela não pode bastar-se com a ordem e com a liberdade. Ela supõe também a solidariedade. Nas palavras de COSTA PINTO: 'um processo penal que ignore as vítimas dos crimes não realiza plenamente o objetivo da justiça penal, nem no sentido ideal, nem na dimensão material do Estado de Direito, fundado sobre o respeito e a dignidade das pessoas"”. (destaques da autora). (SANTOS. Cláudia
} 
podem ser desprezados no âmbito de um processo penal, o que enseja que tais sujeitos sejam inseridos no processo e que lhes sejam atribuídos papéis de destaque, e não meramente secundários, falando-se, nesse sentido, de sua condição de protagonistas, ${ }^{547}$ concorrendo para a formação de um verdadeiro tripé para a preservação da coexistência social. $^{548}$

Quanto a esse protagonismo da vítima, não se pode, porém, falar, de um protagonismo excludente, típico da idade de ouro, mas se deve falar agora de um protagonismo controlado, ${ }^{549}$ partilhado, desta feita, com os demais atores do processo penal: o ofensor/vitimário e a sociedade, os quais também merecem a tutela estatal, impedindo-se, assim, a sobreposição, a priori, das vítimas sobre os demais, redundando no equívoco do vitimocentrismo. ${ }^{550}$

Cruz. A "redescoberta" da vítima e o direito processual penal português. In: ANDRADE, Manuel da Costa Andrade; ANTUNES, Maria João; SOUSA; Susana Aires de. (Org.). Estudos em homenagem ao prof. doutor Jorge de Figueiredo Dias. Coimbra: Coimbra Editora, 2010. v. 3. p. 1133-1153, p. 1150-1151).

${ }^{547}$ Um modelo processual que conte com a necessária participação de vitimário, vítima e sociedade, sendolhes assegurado, a cada um, uma tutela jurídico-processual, representa um avanço em relação a meios de solução de conflitos ou a modelos processuais, historicamente verificáveis, estruturados sobre a exclusão de qualquer daqueles sujeitos. Tome-se, por exemplo, a autocomposição de conflitos (exclusão da sociedade), o sistema inquisitorial medieval (exclusão do acusado, tido como mero objeto do processo) e o modelo processual penal moderno (exclusão das vítimas).

${ }_{548}$ Para SALIBA, "O tripé para a preservação da coexistência social, por meio da pacificação dos conflitos sociais, não se faz pelo Direito penal tradicional, mas funda-se num modelo com efetiva participação do desviante, ofendido e comunidade". (SALIBA, Marcelo Gonçalves. Justiça restaurativa e paradigma punitivo. Curitiba: Juruá, 2009, p. 120).

549 Sobre o protagonismo excludente, da idade de ouro e o protagonismo controlado, inspirado pelo Movimento Vitimológico, cf. BERISTAIN IPIÑA, Antonio (et. al.). Proceso penal y víctimas: pasado, presente y futuro. In: Politica criminal, derechos humanos y sistemas jurídicos en el siglo XXI: volumen de homenaje al prof. Dr. Pedro R. David en su 72. aniversario (21/7/1929). Buenos Aires: De Palma, 2001, p. 123-148.

${ }^{550}$ Nesse contexto, acreditamos que devem ser vistas com alguma reserva posturas vitimológicas mais entusiastas, como as que defendem a aplicação de um princípio in dubio pro víctima em contraposição ao in dubio pro reo, o que pode facilmente descambar no vitimocentrismo. BERISTAIN IPIÑA defende a aplicação de tal princípio, ao interpretar, sob um paradigma hermenêutico vitimológico, o art. 13, da Ley de Enjuiciamiento Criminal espanhola ("Se consideran como primeras diligencias la de consignar las pruebas del delito que puedan desaparecer, la de recoger y poner en custodia cuanto conduzca a su comprobación y a la identificación del delincuente, la de detener, en su caso, a los presuntos responsables del delito, y la de proteger a los ofendidos o perjudicados por el mismo, a sus familiares o a otras personas, pudiendo acordarse a tal efecto las medidas cautelares a las que se refiere el artículo 544 bis o la orden de protección prevista en el artículo 544 ter de esta Ley.)", (destaques nossos), sem contudo, oferecer, aparentemente, critérios mais precisos para sua aplicação: "[...] Que la interpreten y apliquen sobre paradigmas hermenêuticos victimológicos y que, logicamente, den varios passos hacia adelante. Uno de los primeiros será superar el dogma tradicional 'in dubio pro reo' y sustituirlo (no siempre, pero sí con frecuencia) por el de 'in dubio pro victima'. Es decir, inclinar la balanza de la justicia en favor de las víctimas cuando se dude de cuál de los platillos pesa más. Los argumentos tradicionalmente considerados indiscutibles en favor del reo se apoyaban y apoyan en uma cosmovisión impersonal y estatal del delito: enfrentamento lesivo del acusado contra la autoridade o el Estado o el bien común, entendido éste de una manera muy difusa e impersonal. Hoy, cada día más, se concibe el delito en cuanto lesión o daño o perjuicio que el acusado ha inferido diretamente a las víctimas e indirectamente a la sociedade, Pero si caemos en la cuenta de que los delitos, especialmente algunos como los cometidos contra la liberdad e indemnidad sexuales [...] son ante todo causación de daños a personas concretas, y sólo 'em segundo o tercer lugar' a la sociedade em 
Tecidas tais considerações, abordando em especial a figura do assistente, tal qual hodiernamente prevista no ordenamento jurídico-processual penal brasileiro, percebese que tal sujeito precisa de modificações quanto à sua conformação jurídica, a fim de ajustar-se às demandas vitimológicas decorrentes da Dignidade da Pessoa Humana.

Partindo de uma perspectiva que conceba o processo penal como um espaço para a coexistência de três polos de interesses, o do acusado, o da sociedade (representada pelo Ministério Público) e o da vítima, pode-se vislumbrar que essa possa exercer de modo autônomo suas faculdades processuais, independentemente da atuação do Ministério Público, livrando-se, assim, da pecha de mero auxiliar da acusação, aproximando-se, grosso modo, da figura do querellante conjunto. ${ }^{551}$

Ao assistente, assim, deveriam ser asseguradas, na medida do possível, as mesmas faculdades processuais dos demais protagonistas, sujeitando-se às mesmas limitações, encontrando-se, inclusive, de igual modo como o acusado, jungido aos termos da acusação oficial.

Em face de tal panorama, abre-se um parêntese para a indagação anteriormente formulada, que permaneceu em aberto ${ }^{552}$ : uma conformação assim tornaria o assistente uma parte? Não obstante as ponderações anteriormente consideradas neste estudo sobre o conceito de parte e sua perspectivação peculiar em processo penal, talvez seja mais apropriada uma revisitação do conceito de parte à luz da teoria do processo como procedimento em contraditório, de FAZZALARI. ${ }^{553}$

general, compreenderemos que el magistrado debe antender y proteger preferencialmente a las víctimas." (BERISTAIN IPIÑA. Antonio. Nuevo processo penal desde las víctimas. In: MESSUTI, Ana; SAMPEDRO ARRUBLA, Julio Andrés. (Coord.). La administración de la justicia en los albores del tercer milenio. Buenos Aires: Editorial Universidad, 2001. p. 17-33, p. 26-27).

${ }^{551}$ A doutrina argentina faz uma distinção entre querellante conjunto e querellante adhesivo. Segundo LANZÓN, "el Código Procesal Penal de la Nación regula el querellante conjunto, distinto del adhesivo, puesto que en este último - instaurado antiguamente por la legislación alemana - sólo se da al querellante la posibilidad de 'adherirse'a la acusación y conclusiones del Ministerio Fiscal. Se muestra en realidad como un colaborador del fiscal; por el contrario, el conjunto, si bien actúa juntamente con el fiscal, tiene certa autonomía respecto del acusador público (p.ej., faculdades recursivas propias)". (LANZÓN, Román P. La intervención de la víctima en el proceso penal y su derecho a actuar como querellante. In: GUZMÁN, Nicolás. (Coord.). El sistema penal en las sentencias recientes de los órganos interamericanos de protección de los derechos humanos. Buenos Aires: Ad Hoc, 2009. p. 223-250, p. 227).

${ }^{552}$ Vide item 5.2.1

553 Para FAZZALARI, o processo se diferencia do procedimento em razão justamente da necessária existência, em seu âmbito, de uma estrutura dialética: o contraditório: "Não basta, para distinguir o processo do procedimento, o relevo que no processo tem a participação de mais sujeitos, cujos atos que o constituem são movidos não somente pelo autor do ato final, mas também por outros sujeitos. Como ressaltado, quando se fala de procedimento 'plurissubjetivo', refere-se ao esquema de atividade em sequência, movida por mais sujeitos, que se distingue do esquema do verdadeiro e próprio processo. De resto, ninguém considera que a participação do privado que consiste no pedido de licença de caça, e a participação do órgão consultivo que fornece ao autor do provimento o próprio parecer transforme o procedimento em processo. É necessária alguma coisa a mais e diversa; uma coisa os arquétipos do processo nos permitem observar: a estrutura 
Sob a ótica de FAZZALARI, por legitimação para agir pode-se entender a legitimação para o processo. Assim, poderão participar do processo todos aqueles que, ainda que potencialmente, possam vir a ser afetados pelo provimento (a sentença). Esse aspecto é identificado pelo autor como situação legitimante, isto é, "situação com base na qual se determina qual é o sujeito que, concretamente, pode e deve cumprir um certo ato", distinguindo-se de situação legitimada, a saber, "o poder, faculdade ou dever - ou uma série deles - que, por consequência, cabe ao sujeito identificado, vale dizer, corresponde ao conteúdo da legitimação no qual ela consiste". 554

Nos termos de FAZZALARI, a legitimação para agir no processo "é determinada em função do provimento ao qual ele visa e que é contemplado por hipótese (independentemente, é óbvio, daquilo que será efetivamente o fim do processo, do qual pelo menos uma medida será emanada)". 555

Com isso, referido autor altera o conceito de parte, cujo foco se afasta do pedido, e se desloca para o provimento e seus efeitos. Dessarte, partes no processo são considerados os contraditores, aqueles que atuam no processo exercendo seus poderes, faculdades ou deveres, ${ }^{556}$ em razão da eficácia potencial do provimento, independentemente do rótulo de autor, réu ou terceiro. Nesse sentido, "todos os afetados pelo provimento jurisdicional, sejam autores, réus, intervenientes ou assistentes, são

dialética do procedimento, isto é, justamente, o contraditório. Tal estrutura consiste na participação dos destinatários dos efeitos do ato final em sua fase preparatória; na simétrica paridade das suas posições; na mútua implicação das suas atividades (destinadas, respectivamente, a promover e impedir a emanação do provimento); na relevância das mesmas para o autor do provimento; de modo que cada contraditor possa exercitar um conjunto - conspícuo ou modesto, não importa - de escolhas, de reações, de controles, e deva sofrer os controles e as reações dos outros, e que o autor do ato deva prestar contas dos resultados. Veja-se, por exemplo, a fase que precede uma sentença civil de condenação e na qual se recolhem os elementos com base nos quais o juiz deverá emanar tal sentença ou não: dela participam os destinados a serem beneficiários da condenação e os que são destinados a submeter-se a ela, em contraditório entre eles, isto é, desenvolvendo simétricas atividades entre eles, destinadas a fornecer ao juiz - que não poderá abster-se - elementos a favor e contrários àquela emanação. Existe, em resumo, o 'processo', quando em uma ou mais fases do iter de formação de um ato é contemplada a participação não só - e obviamente - do seu autor, mas também dos destinatários dos seus efeitos, em contraditório, de modo que eles possam desenvolver atividades que o autor do ato deve determinar, e cujos resultados ele pode desatender, mas não ignorar”. (FAZZALARI, Elio. Instituições de direito processual. Tradução de Elaine Nassif. Campinas: Bookseller, 2006, p. 119-120).

554 FAZZALARI, Elio. Instituições de direito processual. Tradução de Elaine Nassif. Campinas: Bookseller, 2006, p. 369.

555 FAZZALARI, Elio. Instituições de direito processual. Tradução de Elaine Nassif. Campinas: Bookseller, 2006, p. 369.

${ }^{556}$ Para FAZZALARI, os atos das partes podem ser definidos como posições subjetivas, compreendendo poderes (declarações de vontade, por exemplo, o poder de aprovar um jurado), faculdades (meros atos, como a faculdade de alegar fatos) ou deveres: Ibid., p. 499. Ao passo que para a parte existiria uma posição subjetiva composta (poderes, faculdades e deveres), para o juiz configurar-se-ia outra posição, que consiste na série de seus deveres. (FAZZALARI, Elio. Instituições de direito processual. Tradução de Elaine Nassif. Campinas: Bookseller, 2006, p. 501). 
considerados partes e possuem ação, no conceito de Fazzalari [...]". 557

Assim, também o assistente pode ser considerado parte, na acepção fazzalariana, visto que pode ser afetado pelo provimento jurisdicional, dada a existência de interesses jurídicos que lhe são próprios, ${ }^{558}$ atingíveis pela sentença, ${ }^{559}$ respondendo-se, assim, à indagação anteriormente formulada acerca da categorização jurídica do assistente como parte ou terceiro.

Tal conformação de parte (na acepção fazzalariana) autônoma, coprotagonista do processo penal, careceria de algumas modificações a serem efetuadas na lei processual penal brasileira, de modo a se superarem os empecilhos hoje existentes para sua devida implementação.

A princípio, deve-se questionar sobre a forma pela qual se dá o ingresso do assistente no processo. Pela atual sistemática, após o oferecimento da denúncia, ${ }^{560}$ a vítima pode requerer sua habilitação como assistente, e caso seja deferida, ingressa no processo no estado em que esse se encontre. Pois bem, o problema é que, na prática, a vítima dificilmente tem conhecimento acerca da instauração do processo penal, tratando-se de ato que inicialmente somente envolve o conhecimento do Ministério Público, que oferta a acusação, e do juiz, que a recebe, e posteriormente, do acusado, que é citado.

Para evitar o desenvolvimento dos atos processuais ao completo alheamento da vítima, talvez se devesse criar um mecanismo obrigatório de comunicação, reforçando-se seu direito à informação. Assim, ao receber a denúncia, o juiz poderia, além de determinar a citação do acusado, determinar a notificação do ofendido - em sendo possível a identificação deste ${ }^{561}$ - a fim de participar do processo, remetendo-lhe cópias da peça acusatória.

A disponibilização da notificação da vítima não implicaria sua participação

\footnotetext{
${ }^{557}$ BARROS, Flaviane de Magalhães. A participação da vítima no processo penal. Rio de Janeiro: Lumen Juris, 2008, p. 181.

${ }^{558}$ Cf. item 5.2.2.

559 Descendo às minúcias do processo penal, FAZZALARI chega a analisar a situação legitimante do Ministério Público, órgão do Estado, pessoa jurídica sobre a qual incidirão os efeitos de hipotética sentença condenatória, do imputado, destinatário desse eventual condenação, da parte civil e do responsável civil, destinatários dos efeitos da condenação ao ressarcimento. (FAZZALARI, Elio. Instituições de direito processual. Tradução de Elaine Nassif. Campinas: Bookseller, 2006, p. 408-410). Observe-se que no processo penal italiano, a vítima pode intervir como parte civil e como persona offessa dal reato, contudo, o autor somente cuidou da intervenção civilística da vítima como parte civil, olvidando a intervenção com fins penalísticos.

${ }^{560}$ No que concerne à admissão do assistente já na fase da investigação preliminar (inquérito policial ou procedimentos equivalentes), mesmo que fossem disponibilizados para a vítima mecanismos mais efetivos para o controle da acusação pública, nada impediria tal possibilidade. Todavia, a fim de evitar o desequilíbrio entre vítima e vitimário, seria forçoso que se garantisse ao suspeito/investigado/indiciado simétrica condição, ou seja, que fossem a este oportunizados mecanismos jurídicos de atuação equivalentes.

${ }^{561}$ Essa notificação seria inviável em caso de crimes de vítimas difusas.
} 
obrigatória, dado que deve ser respeitada a vontade daquela em participar ou não do processo penal. Assim, sua efetiva notificação, independentemente de seu comparecimento efetivo, permitiria a continuidade dos atos processuais.

Ainda quanto a tal mecanismo, cumpre registrar a existência de mecanismos similares, por exemplo, no processo penal português, de modo que o magistrado do Ministério Público, ao deduzir a acusação, deve notificar o arguido, o assistente, o denunciante com faculdade de constituir-se assistente, e aquele que tiver manifestado propósito em deduzir pedido indenizatório, possibilitando-lhes, assim, a respectiva participação processual subsequente (Código de Processo Penal português, art. 283, 5), bem como no processo penal italiano, em que o juiz manda notificar a persona offesa dal reato para participar da udizenza preliminare, ato anterior ao giudizio (c.p.p., 419, $1^{562}$ ).

Outro ponto a ser modificado consiste na mera faculdade de proposição de produção probatória, que se reserva ao assistente, a qual precisa ser convertida em verdadeiro direito à prova.

A importância do direito à prova pode ser depreendida de sua abrangência, já que se divide em vários direitos por demais relevantes. Segundo FERNANDES, esse direito à prova compreende: a) direito de requerer a produção de prova; b) direito a que o juiz decida sobre o pedido de produção da prova; c) direito a que, deferida a prova, esta seja realizada, tomando-se todas as providências necessárias para sua produção; d) direito a participar da produção da prova; e) direito a que a produção da prova seja feita em contraditório; f) direito a que a prova seja produzida com a participação do juiz; g) direito a que, realizada a prova, possa manifestar-se a seu respeito; h) direito a que a prova seja objeto de avaliação pelo julgador. ${ }^{563}$

Por sua vez, GOMES FILHO vislumbra no direito à prova os seguintes direitos: a) direito à investigação; b) direito de proposição de provas; c) direito à admissão das provas propostas; d) direito à exclusão das provas inadmissíveis, impertinentes ou irrelevantes; e) direito sobre o meio de prova, ou seja, de participação nos atos de produção da prova; f) direito à avaliação da prova. ${ }^{564}$

Assim, permitir-se ao assistente a participação no processo sem que se lhe

\footnotetext{
562 "Il giudice fa notificare all'imputato e alla persona offesa, della quale risulti agli atti l'identità e il domicilio, l'avviso del giorno, dell'ora e del luogo dell'udienza, con la richiesta di rinvio a giudizio formulata dal pubblico ministero e con l'avvertimento all'imputato che non comparendo sarà giudicato in contumácia". ${ }^{563}$ FERNANDES, Antônio Scarance. Processo penal constitucional. 6. ed. rev. atualiz. ampl. São Paulo: Revista dos Tribunais, 2010, p. 73.

564 GOMES FILHO, Antônio Magalhães. Direito à prova no processo penal. São Paulo: Revista dos Tribunais, 1997, p. 85-89.
} 
garanta o direito à prova, na verdade, constitui verdadeiro desrespeito à dignidade da vítima e a seu direito fundamental à tutela jurisdicional efetiva, assegurado no ordenamento jurídico brasileiro, devendo ser adotadas as modificações necessárias para a implementação desse direito à prova.

Ainda em relação ao direito à prova, deve ser assegurada também a possibilidade de o assistente arrolar testemunhas. Assim, nada impediria que, por ocasião da notificação inicial para participar do processo, fosse facultada ao assistente a possibilidade de arrolar testemunhas em relação aos fatos imputados na acusação formulada. $^{565}$

Contudo, deve-se ressalvar que o número de testemunhas arroladas pelo assistente, deve ser contabilizado com o número de testemunhas arroladas pelo Ministério Público, de modo que o limite máximo de testemunhas para ambos seja igual ao limite máximo de testemunhas para o acusado, evitando-se o desequilíbrio em detrimento desse último sujeito processual.

Cumpre registrar ainda a imprescindibilidade de modificação das regras relativas ao direito recursal do assistente. Como já visto, tal direito mostra-se excessivamente limitado. A uma, porque é de caráter supletivo, pois que está condicionado à não interposição de recurso pelo Ministério Público; a duas, porque somente se confere ao assistente a faculdade de impugnar, por apelação, as sentenças de absolvição e de impronúncia, e por recurso em sentido estrito, a sentença que declara a extinção de punibilidade, ${ }^{566}$ podendo, em relação a tais decisões, também interpor embargos de declaração, bem como recursos especial e extraordinário (Súmula n. 210, do STF), além de, para alguns, nas hipóteses em que interpuser a apelação, se esta for denegada, interpor recurso em sentido estrito com fulcro no Código de Processo Penal, art. 581, XV.

Como se pode inferir, todas as demais hipóteses de impugnação se encontram vedadas ao assistente, como, por exemplo, a impugnação da decisão que não receber a denúncia, a que declare a incompetência do juízo, e mesmo a que conceda habeas corpus.

Dessa forma, propõe-se que seja conferida legitimação plena ao assistente, compreendendo-se, a princípio, desde que presente interesse recursal, todas as hipóteses recursais manejáveis pelos demais sujeitos processuais parciais, havendo ou não

\footnotetext{
${ }^{565}$ Podendo o assistente também, nesse azo processual, propor outros meios de prova.

${ }^{566}$ Se a extinção de punibilidade for declarada em sentença de absolvição sumária, o recurso cabível e manejável pelo assistente será a apelação, por força do disposto no Código de Processo Penal, art. 397, IV c/c art. 593, I.
} 
interposição de recursos por parte do Ministério Público. ${ }^{567}$

Cumpre registrar ainda que algumas matérias devem ser mantidas em sua regulamentação atual, dispensando-se modificações. A título de exemplo, cite-se a necessidade de habilitação formal do assistente para o exercício de suas atribuições. Longe de cuidar-se de uma mera formalidade destituída de sentido, o procedimento de habilitação mostra-se de grande utilidade.

De fato, além das vantagens anteriormente referidas, inclusive para a vítima que ganha estabilidade como sujeito processual, ${ }^{568}$ serve referido procedimento para preservar a ordem do processo. Atuações esporádicas, principalmente no caso de pluralidade de vítimas sem habilitação formal, poderiam ensejar um verdadeiro tumulto processual.

Ademais, partindo do pressuposto de que a participação da vítima enriquece o diálogo processual, esse enriquecimento será bem significativo em caso de uma atuação permanente e estável do que em caso de intervenções isoladas e esporádicas.

Faz-se necessário consignar, ainda, que o procedimento para habilitação como assistente é simples, não constituindo qualquer entrave para o trâmite do processo penal, visto sua singeleza e a facilidade de sua apreciação, por envolver estritamente a questão da legitimação. Inclusive, em situações de urgência, como a necessidade de requerer prisão preventiva ou medida cautelar pessoal, o interessado pode pleitear, na mesma oportunidade, sua habilitação e a prisão ou medida pretendida. ${ }^{569}$

Dado o maior grau de autonomia que se propõe à figura do assistente, poderse-ia sugerir a atribuição a esse sujeito processual da faculdade conferida a seu equivalente no processo penal português, a saber, a de deduzir acusação formal independentemente da acusação pública formulada pelo Ministério Público (Código de Processo Penal português, art. 69, 2, "b" $\left.{ }^{570}\right)$.

Entretanto, tal atribuição, que em aparência representa uma maior sintonia com os propósitos vitimológicos, não nos parece de maior utilidade. Isso porque, considerando

\footnotetext{
${ }^{567}$ No mesmo sentido, o Código de Processo Penal português, que em seu art. 69, 2, "c", assegura aos assistentes "interpor recurso das decisões que o afectem, mesmo que o Ministério Público o não tenha feito", bem como a lei processual alemã que garante direito recursal autônomo ao Nebeklanger.

${ }^{568}$ Vide item 5.2.3.

${ }^{569}$ Observe-se que países como a Alemanha, Portugal e a Argentina, preveem regras específicas para o procedimento de habilitação, sendo esse procedimento também necessário para a participação das vítimas no próprio Tribunal Penal Internacional.

570 " 69.2 - Compete em especial aos assistentes: [...] b) deduzir acusação independentemente da do Ministério Público e, no caso, de procedimento dependente de acusação particular, ainda que aquele a não deduza."
} 
que o juízo sobre a dedução da acusação nas ações penais relativas aos crimes públicos, em Portugal, também seja privativo do Ministério Público, ${ }^{571}$ a acusação deduzida pelo assistente se mostra totalmente vinculada à acusação pública. Prova disso é que o art. 284, 1, do Código processual penal lusitano, enuncia que "o assistente pode também deduzir acusação pelos factos acusados pelo Ministério Público, por parte deles ou por outros que não importem alteração substancial daqueles", oportunizando-se, ainda, ao assistente, a mera adesão aos termos da acusação pública (art. 284, 2, “a”).

Assim, essa acusação pelo assistente, em si, não lhe traz vantagem significativa. Na verdade, a grande benesse da possibilidade de dedução de acusação pelo assistente, tal qual regulada no art. 284 do estatuto processual penal português, no que pese a desconfortante coexistência formal de duas acusações no mesmo processo ${ }^{572}$ (embora uma esteja restrita substancialmente aos termos da outra), parece residir na possibilidade de o assistente poder, desde o início do processo, indicar elementos de prova e requerer sua produção. Entretanto, essa atribuição, consoante as sugestões aqui apresentadas em relação ao processo penal brasileiro, já seria oportunizada ao assistente por ocasião de sua notificação judicial quando do recebimento da denúncia, o que tornaria qualquer peça acusatória do aludido sujeito processual verdadeiramente supérflua. ${ }^{573}$

Por fim, pode-se afirmar que todas as considerações ora tratadas resultariam no questionamento acerca da própria denominação dada pela lei ao instituto, pois que o termo assistente parece pressupor uma subalternidade (à atuação do Ministério Público). Andou melhor o legislador argentino que se refere ao querellante, distinguindo este do querellante exclusivo, que corresponde ao autor da ação penal de iniciativa privada. ${ }^{574}$

Talvez, à similaridade do direito argentino, se pudesse denominar o assistente de querelante, e o autor da ação penal de iniciativa privada de querelante exclusivo. Essa questão, todavia, é de somenos importância, dada a relevância das demais questões

\footnotetext{
${ }^{571}$ Assim como no Brasil.

${ }^{572}$ Conferir análise sobre a multiplicidade de acusações no processo penal argentino e o direito a um só discurso acusatório: PANDOLFI, Oscar Raúl. El derecho del imputado a um acusador penal único (o a un solo discurso acusatorio del que defenderse). Córdoba: Ediciones del Copista, 2010, passim.

${ }^{573}$ Eis o artigo $284 .^{\circ}$, do CPPP, em sua íntegra, que trata da "acusação pelo assistente": "1 - Até 10 dias após a notificação da acusação do Ministério Público, o assistente pode também deduzir acusação pelos factos acusados pelo Ministério Público, por parte deles ou por outros que não importem alteração substancial daqueles. 2 - É correspondentemente aplicável o disposto nos n.os 3 e 7 do artigo anterior, com as seguintes modificações: a) A acusação do assistente pode limitar-se a mera adesão à acusação do Ministério Público; b) Só são indicadas provas a produzir ou a requerer que não constem da acusação do Ministério Público".

${ }^{574}$ Cf. BERTOLINO, Pedro J. La situación de la víctima del delito en el proceso penal de la Argentina. In: BERMÚDEZ, Victor Hugo et al. La víctima en el proceso penal: su régimen legal en Argentina, Bolivia, Brasil, Chile, Paraguay, Uruguay. Prefácio de Ada Pellegrini Grinover. Buenos Aires: Depalma, 1997, p. 168, passim.
} 
apresentadas.

\subsubsection{O assistente no Código projetado: a perda de uma oportunidade}

O Código de Processo Penal projetado (substitutivo do PLS 156/09), já aprovado no Senado Federal, ${ }^{575}$ traz prevista, em seu bojo, a extinção da ação penal de iniciativa privada principal, ressalvando, porém, a permanência da ação de iniciativa privada subsidiária como instrumento de controle da morosidade do Poder Público. Segundo sua exposição de motivos, o estágio atual de minimalismo interventivo penal não comportaria a possibilidade de uma ação penal que ficasse à disposição dos interesses e motivações do particular, ainda que se tratasse da vítima da infração penal. ${ }^{576}$

Como contraponto à supressão dessa espécie de ação penal, o Código projetado buscou reforçar a participação da vítima no condicionamento da acusação penal (art. 46, caput), conferiu maior ênfase à conciliação e à reparação civil, por meio de dispositivos como o art. 46, $\$ 2^{\circ}$ (que traz a conciliação entre vítima e autor do fato como causa extintiva de punibilidade em crimes contra o patrimônio), bem como estabeleceu, nos arts. 77 a 84, sua participação no processo penal, nas modalidades de assistente e de parte civil.

O assistente, mantido no Código projetado, teve sua atuação, contudo, vinculada exclusivamente ao interesse de reparação de danos, prejudicando os demais interesses de natureza diversa afetos à vítima. A natureza exclusivamente civilística do instituto restou evidenciada na redação original do projeto, que tratava do assistente e da parte civil no capítulo IV, do Título IV, do Livro I, que se intitulava "Da intervenção civil", 577 constando na própria apresentação de motivos que "[...] a vítima, enquanto parte civil, poderá ingressar nos autos, não só como assistente da acusação, mas também, ou apenas, se assim decidir, como parte processual a ser contemplada na sentença penal condenatória". ${ }^{578}$ (destaque nosso).

\footnotetext{
${ }^{575}$ Cf. BRASIL. Congresso. Senado. Projeto de Lei do Senado no 156/09: redação final. Disponível em: <http://www.senado.gov.br/atividade/materia/getPDF.asp?t=85509\&tp=1 >. Acesso em: 15 mar. 2011.

576 BRASIL. Congresso. Senado. Projeto de Lei do Senado n⿳ 156/2009: texto inicial. Disponível em: $<$ http://legis.senado.gov.br/mate-pdf/58503.pdf>. Acesso em: 21 out. 2010.

${ }^{577}$ Esse capítulo, na redação final aprovada no Senado Federal, passou a denominar-se "Do assistente e da parte civil", tornando-se o capítulo V.

${ }^{578}$ Disponível em: Congresso. Senado. Projeto de Lei do Senado no 156/2009: texto inicial. Disponível em: $<$ http://legis.senado.gov.br/mate-pdf/58503.pdf>. Acesso em: 21 out. 2010.
} 
Sob tal ótica, o art. 76 (caput e $\$ 3^{0579}$ ), permite ao assistente apenas a interposição de recursos contra decisões de absolvição, absolvição sumária, impronúncia e extinção de punibilidade, e em tais casos, a matéria a ser impugnada restringe-se à autoria e à existência do fato.

Por consequência, veda-se ao assistente o manejo de recursos para satisfação de interesses outros, como se daria, por exemplo, para exasperar o quantum de eventual pena imposta. ${ }^{580}$

Em face da tal escolha levada a cabo pelo Código projetado, a condição do assistente torna-se paradoxal, pois ser-lhe-ia facultado colaborar com o Ministério Público quanto à pretensão penal processual do Estado, desde que esteja imbuído apenas do interesse civil de reparação de danos, ou seja, nos limites de seu intento para obtenção da sentença condenatória penal como título executivo judicial. ${ }^{581}$

Sob essa perspectiva projetada, a vítima habilitada como assistente padeceria de uma verdadeira crise de identidade, pois nem se encaixaria na figura do assistente previsto no Código de 1941, que tem reconhecida sua atuação na defesa de seu interesse penal, tal qual concebido pela ampla maioria dos autores jurídicos nacionais, nem tampouco pode ser identificada com a parte civil, incorporada pelo Código projetado, que

\footnotetext{
579 “Art. 76. Ao assistente será permitido propor meios de prova, formular perguntas às testemunhas, à vítima e ao acusado, participar dos debates orais, formular quesitos ao exame pericial, requerer diligências complementares ao final da audiência de instrução, apresentar memoriais e arrazoar os recursos interpostos pelo Ministério Público, ou por ele próprio, nas hipóteses de absolvição, de absolvição sumária, de impronúncia ou de extinção da punibilidade. [...] $\S 3^{\circ} \mathrm{O}$ recurso do assistente limitar-se-á ao reconhecimento da autoria e da existência do fato."

${ }^{580}$ O que já vem despertando inconformismo: "Essa noção de assistência exclusivamente civil, visualizada no título da seção do diploma legal, vai no sentido de limitar a atuação da vítima, restringindo a possibilidade de realização de atos processuais relevantes para garantir seus direitos fundamentais. Tal perspectiva, infelizmente, se reflete nos limites para sua atuação na fase recursal, que já existiam no CPP atual e está previsto na proposta de reforma total. Define-se que a decisão impugnável pela vítima de forma autônoma é a de absolvição, absolvição sumária, impronúncia e extinção de punibilidade. Com um limite ainda maior, pois o recurso se limita a reconhecimento da autoria e existência do fato. Logo, se tal perspectiva for assim interpretada teríamos um verdadeiro retrocesso ante ao compromisso de que o processo penal não seja meio de desrespeitar os direitos fundamentais da vítima causando assim sua sobrevitimação". (BARROS, Flaviane de Magalhães. Direito das vítimas e sua participação no processo penal: a análise do PLS 156/09 a partir de uma interpretação constitucional. In: COUTINHO, Jacinto Nelson de Miranda; CARVALHO, Luis Gustavo Grandinetti Castanho de (Org.). O novo processo penal à luz da constituição (análise crítica do projeto de lei $\mathbf{n}^{\mathbf{0}} \mathbf{1 5 6 / 2 0 0 9}$, do senado federal). Rio de Janeiro: Lumen Juris, 2010, p. 327).

581 "[...] o que se extrai dos dispositivos invocados é que a finalidade da assistência é obter uma sentença penal que melhor proteja seu interesse jurídico de recompor o dano causado pela infração penal [...]". (CARVALHO, Luís Gustavo Grandinetti de. Quando o público e o privado se encontram no projeto: assistência, indenização e composição. In: COUTINHO, Jacinto Nelson de Miranda; CARVALHO, Luis Gustavo Grandinetti Castanho de (Orgs.). O novo processo penal à luz da constituição (análise crítica do projeto de lei $\mathbf{n}^{\mathbf{0}} \mathbf{1 5 6 / 2 0 0 9}$, do Senado Federal). Rio de Janeiro: Lumen Juris, 2010, p. 317). Sob tal ótica, o art. $76, \S 1^{\circ}$, que cuida do juízo de admissibilidade sobre os meios de prova propostos pelo assistente, a cargo do juiz da causa, ouvido o Ministério Público, serviria para viabilizar a adequação da atuação processual do assistente a interesse exclusivamente cível.
} 
lhe reconhece pretensão civil autônoma e faculdades processuais mais amplas, próprias de parte, situando-se em uma encruzilhada, o que abre espaço para se questionar acerca da real necessidade de tal instituto, tal qual previsto nos arts. 74 a 77 do Código projetado. ${ }^{582}$

E mais, a redação do $\S 3^{\circ}$, do art. 76 , que tem por objeto atrelar a assistência ao interesse de reparação de danos, chega a prejudicar, em alguns casos, esse mesmo interesse. Basta imaginar a situação em que o assistente, imbuído hipoteticamente do anseio de obter seu título executivo judicial, se vê impossibilitado de recorrer de uma decisão que venha a absolver o imputado com fundamento na atipicidade do fato, matéria distinta da autoria e da materialidade do fato, assistindo à extinção do processo sem nada poder fazer, a não ser ajuizar outra ação, desta feita, no juízo cível.

Ainda quanto à matéria recursal, o Código de Processo Penal atualmente vigente, em seus arts. 271 , caput, $584, \S 1^{\circ}$, e 598, expressamente condiciona a interposição de recursos pelo assistente, quer seja habilitado nos autos ou não, à inércia recursal do Ministério Público. Essa regra mantém-se sob o Código projetado, pois embora seu art. 76, caput, não contenha qualquer referência direta ou indireta a uma atuação supletiva, seu art. $480^{583}$ praticamente reproduz o teor do art. 598 do atual Código, que justamente trata dessa regra de atuação supletiva.

Assim, a interpretação conjunta de ambos os dispositivos (arts. 76, caput, e 480) se mostra suficiente para manter a referida limitação ao assistente do Ministério Público no que concerne à interposição de recursos.

Por fim, o Projeto exclui a regra de proibição de o corréu habilitar-se no mesmo processo como assistente (Código de Processo Penal atual, art. 270), o que não parece positivo, pois mesmo que haja interesses antagônicos entres os corréus ${ }^{584}$, tal proibição tem o condão de evitar a confusão no desempenho de seus respectivos papéis

\footnotetext{
${ }^{582}$ No contexto do Código projetado, considerando-se que à parte civil somente se reconhece interesse de reparação de danos morais, a única utilidade da assistência seria colaborar com a acusação pública para obter a sentença condenatória para servir de título executivo exclusivamente quanto a danos patrimoniais. Essa questionável dicotomia entre interesses patrimoniais e morais será objeto de análise mais acurada quando da apreciação do tema adesão civil.

583 "Art. 480. Nos crimes da competência do Tribunal do Júri, ou do juiz singular, se da sentença não for interposta apelação pelo Ministério Público no prazo legal, a vítima ou qualquer das pessoas enumeradas no art. 74, ainda que não se tenha habilitado como assistente, poderá interpor apelação. Parágrafo único. O prazo para interposição do recurso de que trata o caput deste artigo, contado a partir do dia seguinte em que terminar o do Ministério Público, será de 5 (cinco) dias para o assistente e de 15 (quinze) dias para a vítima não habilitada e demais legitimados."

${ }^{584}$ Cita-se, por exemplo, o caso de denúncia contra dois réus por lesões recíprocas. Conferir CARVALHO, Luís Gustavo Grandinetti de. Quando o público e o privado se encontram no projeto: assistência, indenização e composição. In: COUTINHO, Jacinto Nelson de Miranda; CARVALHO, Luis Gustavo Grandinetti Castanho de (Orgs.). O novo processo penal à luz da constituição (análise crítica do projeto de lei $\mathbf{n}^{\mathbf{0}}$ 156/2009, do Senado Federal). Rio de Janeiro: Lumen Juris, 2010, p. 318.
} 
pelos sujeitos processuais, de modo que não se poderia distinguir claramente até que ponto alguém, em tal situação, agiria no intuito de defender-se ou no intuito de colaborar efetivamente com o Ministério Público.

Registre-se que os dispositivos propostos pelo projeto original (PLS 156/09) em relação à assistência receberam sugestões de modificação. Assim, por exemplo, em fevereiro de 2010, o Instituto dos Advogados Brasileiros (IAB), por sua Comissão Permanente de Direito Penal, enviou um parecer, ${ }^{585}$ em que sugeriu aperfeiçoamentos ao projeto como um todo. No que se refere à figura do assistente, a intenção do IAB mostrava-se bem clara: aproveitar o instituto da assistência, permanecendo o reconhecimento de seu interesse penal.

Deste modo, a IAB recomendava a supressão do $\S 3^{\circ}$, do art. 77 (art. 76 do Substitutivo), que limitava a matéria objeto de impugnação pelo assistente, de modo que prevalecesse a possibilidade de aquele pleitear pelo "deslinde justo da causa, sob sua perspectiva", e não somente por um mero título executivo judicial, bem como a possibilidade de impugnação em razão da não admissão do assistente, dado o caráter objetivo de sua legitimidade (qualidade de ofendido).

Cumpre assinalar que essas modificações sugeridas, não restaram acatadas pelo Poder Legislativo, prevalecendo o texto constante no Substitutivo (Emenda n. 2 - CCJ), aprovado na Comissão de Constituição e Justiça do Senado, em 17 de março de 2010, e no plenário da referida Casa, em 09 de novembro de $2010 .^{586}$

O texto do mencionado Substitutivo, quanto à intervenção civil, mostra-se praticamente idêntico ao texto original constante no Projeto n. 156/09, excetuadas pouquíssimas alterações, de cunho meramente redacional, e o acréscimo de mais duas faculdades processuais ao assistente, de mínima relevância no contexto geral da matéria. ${ }^{587}$

Ao final, pode-se afirmar que, no que concerne ao tratamento conferido ao assistente no Código projetado, pôs-se a perder uma grande oportunidade de ajustar-se a legislação ordinária aos reclamos do direito fundamental à tutela jurisdicional efetiva. $\mathrm{Na}$ verdade, a disciplina projetada sobre o assistente, ao invés de constituir-se um avanço, tende a representar um retrocesso para os anseios vitimológicos.

\footnotetext{
${ }^{585}$ Disponível em: <http://www.iabnacional.org.br/IMG/pdf/doc-2377.pdf〉. Acesso em: 15 jan. 2010.

${ }^{586}$ Publicado no DSF, edição de 10 de novembro de 2010 (páginas 49317 - 49493).

587 As faculdades acrescidas são: a formulação de quesitos ao exame pericial e o requerimento de diligências complementares ao final da audiência de instrução, faculdades essas que inclusive já se encontram incorporadas no CPP, por força da microrreforma de 2008.
} 


\section{DIREITO DA VÍTIMA A UMA SOLUÇÃO CONSENSUAL DO PROCESSO}

\subsection{NOTAS INTRODUTÓRIAS}

Modelos de justiça penal baseados no consenso tem proliferado nos ordenamentos jurídicos processuais penais nacionais, incorporando-se no civil law. $\mathrm{O}$ consenso, que representa, a princípio, uma forma mais célere de resolução do caso penal, conta com outras vantagens, como a participação dos sujeitos processuais parciais, no que se pode e deve incluir a vítima da infração penal, conferindo-se maior legitimidade ao processo penal.

O presente capítulo ocupar-se-á inicialmente sobre o consenso no processo penal, buscando-lhe as origens e visitando conceitos como os de diversão e oportunidade.

Passar-se-á ainda a uma análise sobre o consenso e suas vantagens para o processo penal, ressaltando-se o direito ao consenso como direito da vítima, no que se analisarão, sob ótica crítica, os institutos consensuais atualmente disponíveis no processo penal brasileiro, buscando-lhes o aperfeiçoamento.

Por fim, tendo em vista seu caráter consensual nuclear e sua necessária inclusão da vítima, discorrer-se-á sobre a justiça restaurativa e seus principais caracteres.

\subsection{O CONSENSO NO PROCESSO PENAL E A VÍTIMA}

\subsubsection{O modelo clássico de processo penal e a diversificação}

Desenvolveu-se à época iluminista, no Direito continental europeu (civil law), um modelo próprio de processo penal, que teve no Código de Instrução Criminal francês de 1808, uma configuração que serviu de referência para os demais países europeus.

Como já referido, a desproporção de forças entre Estado e acusado era então 
evidente e precisava ser corrigida em prol deste. Esse modelo de processo penal propunhase a estabelecer algum equilíbrio nas relações entre Estado e acusado. Para tanto, buscouse na lei um elenco de direitos e garantias em favor do indivíduo e oponíveis ao Estado. A pretendida objetividade da lei se deveria impor ao então vigente subjetivismo dos julgadores, de modo a evitar a arbitrariedade e o abuso.

Esse modelo clássico, tido, assim, como instrumento de limitação ao poder estatal, espalhou-se pelos países pertencentes ao sistema romano-germânico, incluindo-se o Brasil, servindo de base para a estruturação de seus respectivos modelos de processo penal.

A modelação processual penal iluminista, contudo, tem sofrido profundo abalo em face do que se pode chamar de crise contemporânea do Direito Penal. Nesse ponto, lançando mão do pensamento de SILVA SANCHÉZ, deve-se advertir que, não obstante ser a crise algo conatural do Direito Penal, ${ }^{588}$ é possível referir-se a uma crise contemporânea do Direito Penal, que também se reflete no Direito Processual Penal e, mais especificamente, nesse modelo clássico de processo penal aludido.

Para SILVA SÁNCHEZ, essa crise diz respeito inicialmente ao problema da legitimidade do Direito Penal, profundamente ligado ao rompimento do esquema de um Direito Penal retributivo, verificado nos anos 60 do século pretérito. ${ }^{589}$

Em acréscimo ao problema da legitimação, que ainda gera algum questionamento, surge um novo e importante fator: trata-se da atual tendência expansionista do Direito Penal, que implica uma verdadeira crise de crescimento, a qual, por vezes, traz consigo o temível Direito excepcional, e que encontra, como obstáculos, a vertente garantista do Direito Penal e o ceticismo em face da eficácia preventivoespecial. $^{590}$

Como se anotou, a crise contemporânea do Direito Penal produz também seus efeitos em relação ao Direito Processual Penal.

De fato, a expansão penal enseja uma cada vez mais crescente demanda no

\footnotetext{
${ }^{588}$ Nesses termos, se manifesta SILVA SANCHEZ: “A alusão a que o Direito Penal está em 'crise' se converteu, em nossos dias, em autentico lugar comum. [...]. A crise, em realidade, é algo congênito ao Direito Penal como conjunto normativo ou, pelo menos, resulta logo imanente ao Direito Penal moderno, surgido da ilustração e plasmado nos primeiros Estados de Direito. Neles, com efeito, a antinomia entre liberdade e segurança (expressa no âmbito penal na tensão entre prevenção e garantias, ou mesmo entre legalidade e política criminal) começa a não ser resolvida automaticamente em favor da segurança, da prevenção; assim já se detecta um princípio de crise, de tensão interna, que permanece em nossos dias." (SILVA SÁNCHEZ, Jesús-María. Aproximação ao direito penal contemporâneo. Trad. Roberto Barbosa Alves. São Paulo: Revista dos Tribunais, 2011. (Coleção Direito e ciências afins, v.7), p. 29-30).

589 SILVA SÁNCHEZ, Jesús-María. Aproximação ao direito penal contemporâneo. Trad. Roberto Barbosa Alves. São Paulo: Revista dos Tribunais, 2011. (Coleção Direito e ciências afins, v.7), p. 30-33.

590 SILVA SÁNCHEZ, Jesús-María. Aproximação ao direito penal contemporâneo. Trad. Roberto Barbosa Alves. São Paulo: Revista dos Tribunais, 2011. (Coleção Direito e ciências afins, v.7), p. 33-34.
} 
número de processos, resultando em lentidão na tramitação e em uma aura de morosidade e ineficiência que paira sobre todo o sistema de justiça penal.

O fato é que os diversos ordenamentos jurídicos nacionais buscaram soluções para tal crise, tanto no âmbito do Direito Penal, quanto no âmbito do Direito Processual Penal, dada a relação de complementaridade funcional existente entre ambos. ${ }^{591}$

No que se refere às soluções engendradas na seara processual - o que interessa mais de perto a este trabalho - destaca-se a diversão.

Por diversão, pode-se entender um verdadeiro programa que "implica a tentativa de encontrar alternativas para a solução dos conflitos de natureza penal diversas do modelo tradicional", 592

Dentro desse conceito, faz-se possível identificar desde uma concepção mais radical, em que o conflito deverá ser resolvido fora do sistema formal de Justiça penal, pelos próprios atores socialmente envolvidos, até uma concepção de cunho menos absoluto, em que o conflito pode ser resolvido no âmbito da Justiça penal, dando-se uma diversificação de ritos processuais. ${ }^{593}$

Para COSTA, a diversão, aqui entendida em sua conotação de gênero, atende às seguintes finalidades: primeiramente evitar o estrangulamento do sistema formal de justiça penal e simultaneamente, aliviar a sobrecarga existente; segundo, manter e intensificar o ideal de reabilitação e reduzir, ao máximo, a estigmatização que pende sobre

${ }^{591}$ Desde a década de 70, DIAS aponta o conceito de Direito Penal Total, que teria por setores o Direito Penal (material), o Direito Processual Penal e o Direito de Execução das Penas, incumbindo-lhe a função de "proteger os bens e valores fundamentais da comunidade através da prevenção de lesões que sejam de recear no futuro (função preventiva) e da punição de lesões que tiveram já lugar (função repressiva)". (DIAS, Jorge de Figueiredo. Direito processual penal. 1. ed. 1974, reimpressão. Coimbra: Coimbra editora, 2004, p. 2627). Dentro de tal unidade, os setores do Direito Penal substantivo e do Direito Penal adjetivo exerceriam influência recíproca entre si, o que evidencia a complementaridade funcional existente entre ambos. DIAS cita, por um lado, que a conformação teleológica fundamental do Direito Penal ganhará repercussão no Direito Processual correspondente, bem como problemas até mesmo processuais concretos têm sua solução condicionada a uma tomada de posição da parte do Direito Penal. Por outro lado, o autor menciona que algumas diretrizes fundamentais no pensamento jurídico-penal são fruto, no todo ou em parte, do resultado de necessidades imperiosas verificadas na práxis processual penal, e que soluções de problemas jurídicoprocessuais podem contribuir para o esclarecimento de intricados problemas verificáveis no seio do Direito Penal substantivo: (DIAS, Jorge de Figueiredo. Direito processual penal. 1. ed. 1974, reimpressão. Coimbra: Coimbra editora, 2004, p. 28-32).

592 FERNANDES, Fernando. O processo penal como instrumento de política criminal. Coimbra: Almedina, 2008. (Coleção teses), p. 133.

593 FERNANDES, Fernando. O processo penal como instrumento de política criminal. Coimbra: Almedina, 2008. (Coleção teses), p. 134. FERNANDES, ao tratar do fenômeno sob a concepção menos absoluta (flexibilização processual dentro da justiça penal), utiliza, quanto ao gênero, em vez de diversificação, o termo simplificação procedimental, denominando suas espécies de alternativas procedimentais simplificadoras (FERNANDES, Antônio Scarance. Teoria geral do procedimento e o procedimento no processo penal. São Paulo: Revista dos Tribunais, 2005, passim). 
o acusado. ${ }^{594}$

A par de uma concepção mais absoluta de diversão, que poderia redundar mesmo em uma justiça privada, benéfica à parte mais poderosa do conflito, a diversificação, ou seja, a simplificação procedimental pode dar-se, segundo FERNANDES, pelos seguintes mecanismos básicos: "a) os que conduzem ao encerramento antecipado do processo; b) os que levam à supressão de fases dos procedimentos ordinários; e c) os que representam uma reorganização do procedimento ordinário". 595

Dentro do contexto da diversificação/simplificação procedimental, ganha significado o princípio da adequação, que, para FERNANDES, pode ser compreendido como a "necessidade de que se adopte uma diversificação de ritos processuais, adequandoos na conformidade da gravidade do delito e da complexidade da sua persecução". 596

Segundo o próprio FERNANDES, aludida adequação não constitui nenhuma novidade para o Direito Processual Penal, citando os tradicionais parâmetros para a criação de procedimentos "aderentes à realidade social", a saber: a gravidade da infração penal, a complexidade do fato a ser apurado e, por fim, particularidades relacionadas com o tipo de crime.

A novidade, para os países do civil law, consistiria agora na pretensão de uma adequação em sentido mais profundo, mediante "o aumento do leque de procedimentos e de alternativas de solução diferenciada", de modo a "reservar os procedimentos ordinários, mais amplos e mais garantistas, para a solução do menor número de casos, destinando-os somente à solução de processos por crimes de maior gravidade ou marcados por maior complexidade". 597

Por fim, não se pode deixar de registrar que essas considerações acerca da diversificação - tida como uma solução, em matéria processual penal, para a crise contemporânea do Direito Penal - passam necessariamente pela análise dos conceitos de legalidade e oportunidade.

A legalidade, presente de modo especial no civil law, impõe que uma vez noticiada a ocorrência de um fato típico-penal, o Estado deve empreender, por suas

\footnotetext{
${ }^{594}$ Cf. COSTA, José Francisco de Faria. Diversão (desjudiciarização) e mediação: que rumos? Boletim da Faculdade de Direito da Universidade de Coimbra, v.61, p. 91-158, 1985, p. 106-108.

${ }^{595}$ FERNANDES, Antônio Scarance. Teoria geral do procedimento e o procedimento no processo penal. São Paulo: Revista dos Tribunais, 2005, p. 59.

596 FERNANDES, Fernando. O processo penal como instrumento de política criminal. Coimbra: Almedina, 2008. (Coleção teses), p. 135.

${ }^{597}$ FERNANDES, Antônio Scarance. Teoria geral do procedimento e o procedimento no processo penal. São Paulo: Revista dos Tribunais, 2005, p. 57-58.
} 
instâncias formais, a persecução penal independentemente do subjetivismo dos atores do sistema. Assim, consoante tal princípio, "o desenvolvimento e o término do processo penal não podem estar submetidos à vontade particular ou a um poder de disposição de determinados sujeitos jurídicos". 598

A oportunidade, de presença mais marcante no common law, surge como contraponto à legalidade, envolvendo um verdadeiro juízo de discricionariedade no processo penal.

Para GIACOMOLLI, um sistema jurídico é regido pela oportunidade "quando os encarregados do ius persequendi podem selecionar os fatos que investigarão e também os possíveis autores dos mesmos, frente à notitia criminis". 599

Dentro desse conceito, não se pode olvidar que ao poder de disposição do acusador oficial corresponde à possibilidade de o "acusado dispor, total ou parcialmente, do devido processo legal, ou mais particularmente do direito de defesa" ${ }^{600}$

Importa observar, ainda com amparo em GIACOMOLLI, a inexatidão da expressão "oportunidade regrada", que se distinguiria da "oportunidade pura". A crítica do autor se baseia no fato de que a oportunidade, em si, não se submete a regra, o que se pode regulamentar é o âmbito objetivo em que pode ser exercido o juízo de oportunidade. ${ }^{601}$

Em face disso, pode-se aqui estabelecer que a diversificação pressupõe um juízo de oportunidade ou, em outros termos, somente pode haver diversificação dentro do contexto de um juízo de oportunidade conferido pela Lei.

Tecidas tais considerações, permita-se desde já antecipar que dentre as formas de diversificação, importa a este estudo aquelas que tenham como critério o consenso, tema a ser abordado no próximo item.

\footnotetext{
598 GIACOMOLLI, Nereu José. Legalidade, oportunidade e consenso no processo penal na perspectiva das garantias constitucionais: Alemanha, Espanha, Itália, Portugal e Brasil. Porto Alegre: Livraria do Advogado, 2006, p. 49.

${ }^{599}$ GIACOMOLLI, Nereu José. Legalidade, oportunidade e consenso no processo penal na perspectiva das garantias constitucionais: Alemanha, Espanha, Itália, Portugal e Brasil. Porto Alegre: Livraria do Advogado, 2006, p. 68. Em outras palavras do mesmo autor, trata-se de um sistema em que "é lícito ao Ministério Público não perseguir todos os fatos delitivos que lhe são submetidos, ou quando pode configurálos prescindindo de circunstâncias fáticas relevantes, do prisma jurídico-penal, segundo as normas objetivas, ou quando the é permitido não se ater à legalidade para valorar juridicamente esses fatos". (GIACOMOLLI, Nereu José. Legalidade, oportunidade e consenso no processo penal na perspectiva das garantias constitucionais: Alemanha, Espanha, Itália, Portugal e Brasil. Porto Alegre: Livraria do Advogado, 2006, p. 68).

${ }^{600}$ GIACOMOLLI, Nereu José. Legalidade, oportunidade e consenso no processo penal na perspectiva das garantias constitucionais: Alemanha, Espanha, Itália, Portugal e Brasil. Porto Alegre: Livraria do Advogado, 2006, p. 64.

${ }^{601}$ GIACOMOLLI, Nereu José. Legalidade, oportunidade e consenso no processo penal na perspectiva das garantias constitucionais: Alemanha, Espanha, Itália, Portugal e Brasil. Porto Alegre: Livraria do Advogado, 2006, p. 70.
} 


\subsubsection{O consenso no processo penal}

O consenso aparece de modo predominante no commom law. Sob seu signo, adversárias contrapostas, as partes podem descer a negociações e firmar um acordo, pondo fim ao processo.

$\mathrm{Na}$ Inglaterra, o plea bargaining, ao lado do direito ao confronto entre as partes, surge sob a égide da ideologia nascente como "produto da Revolução Industrial inglesa e da necessidade de inclinar o equilíbrio político na sala do tribunal longe dos juízes reais e em direção aos representantes das partes". ${ }^{602}$

Partindo de uma confissão de culpa (guilty plea), no caso inglês, os tipos de acordo podem variar: a) pode-se permitir ao acusado e seu defensor que discutam o caso mediante uma caução; b) o acusado pode negociar com a acusação um charge bargain, que pode dar-se sob duas formas: b.1) em face de pluralidade de acusações, o acusado pode reconhecer sua culpabilidade em uma ou algumas, em prejuízo das acusações restantes; b.2) em face de uma única acusação, quando existe uma modalidade menos grave - como homicídio sem premeditação -, o acusado pode negociar a confissão de culpa pela modalidade menos grave; c) ou pode ainda o acusado negociar um fat bargain, em que o acusado confessa sua culpa em troca de se apresentarem os fatos em juízo dentro de uma interpretação mais favorável mutuamente acordada entre as partes. ${ }^{603}$

No sistema de civil law, o consenso não faz parte originariamente do modelo clássico de processo penal. Para VOGLER, em tal sistema, as estratégias consensuais só foram teoricamente possíveis com a admissão do advogado de defesa na Europa continental ao final do século XIX, mas sua implementação prática somente se daria nos anos 70 do século XX, enfrentando-se, contudo, três sérios obstáculos: a ausência de algo equivalente ao guilty plea, que causa estranheza ao processo penal continental, a fragilidade da defesa em face da acusação e o domínio da fase pré-processual pela

\footnotetext{
${ }^{602}$ VOGLER, Richard. Justiça consensual e processo penal. In: CHOUKR, Fauzi Hassan; AMBOS, Kai. (Coord.). Processo penal e estado de direito. Campinas: Edicamp, 2002, p. 284.

${ }^{603}$ VOGLER, Richard. Justiça consensual e processo penal. In: CHOUKR, Fauzi Hassan; AMBOS, Kai. (Coord.). Processo penal e estado de direito. Campinas: Edicamp, 2002, p. 284-285.
} 
investigação de juízes. ${ }^{604}$

Registre-se, desde já, que a influência recíproca entre os sistemas common law e civil law trata-se de um fenômeno que não se pode olvidar e mesmo impossível de refutar nos dias atuais, o que impede qualquer tentativa de empreender uma cruzada em busca da pureza de qualquer desses sistemas.

Tornando ao consenso, pode-se afirmar que sob um modelo consensuado de Justiça penal - um modelo de consenso -, os participantes do processo penal buscam uma solução harmônica, por uma compatibilização das vontades outrora antagônicas. ${ }^{605}$ Ocorre, assim, uma transformação extraordinária: a substituição de um modelo de Justiça penal vertical, imposta, por um modelo de Justiça penal horizontal, convergente, modelo esse que "determina uma nova leitura das bases que fundamentam o processo penal", ${ }^{606}$

Um modelo processual baseado no consenso representa grandes vantagens para o sistema de Justiça penal. Além dos benefícios ínsitos às finalidades da própria diversão, apontados por COSTA, conforme referido no item anterior, ${ }^{607}$ pode-se ressaltar a diminuição dos problemas de legitimação do sistema. ${ }^{608}$

Afinal, a solução para o conflito penal deixa de ser uma imposição estatal, com respaldo na violação de uma abstração denominada bem jurídico, para constituir um acordo, um encontro de vontades entre as partes diretamente envolvidas no conflito, com base em seus respectivos interesses.

Outras vantagens podem ser apontadas com base na lição de HERRERA MORENO, referentes à humanização do sistema em si, que traz benefícios, inclusive, de ordem psicológica aos envolvidos. ${ }^{609}$

${ }^{604}$ VOGLER, Richard. Justiça consensual e processo penal. In: CHOUKR, Fauzi Hassan; AMBOS, Kai. (Coord.). Processo penal e estado de direito. Campinas: Edicamp, 2002, p. 289-290.

605 “[...] o consenso pressupõe a existência de mais de uma parte, em pólos antagônicos, em dissenso, as quais aceitam determinada solução com emissão volitiva em um mesmo sentido, ou de um encontro de vontades." (GIACOMOLLI, Nereu José. Legalidade, oportunidade e consenso no processo penal na perspectiva das garantias constitucionais: Alemanha, Espanha, Itália, Portugal e Brasil. Porto Alegre: Livraria do Advogado, 2006, p. 72). Para HERRERA MORENO, na conciliação, o conflito não se ausenta do Direito Penal, senão de forma relativa e matizada. (SANTANA, Selma Pereira de. Justiça restaurativa: a reparação como consequência jurídico-penal autônoma do delito. Rio de Janeiro: Lumen Juris, 2010, p. 170).

${ }^{606}$ FERNANDES, Fernando. O processo penal como instrumento de política criminal. Coimbra: Almedina, 2008. (Coleção teses), p. 140.

${ }^{607}$ Vide item 6.2.1.

${ }^{608}$ FERNANDES, Fernando. O processo penal como instrumento de política criminal. Coimbra: Almedina, 2008. (Coleção teses), p. 140.

609 "De acordo com HERRERA MORENO, [...] o processo conciliador estimula menor hostilidade e tensão emocional. Não se trata de esclarecer fatos e estabelecer a culpabilidade. Se o processo penal gira em torno da atribuição da responsabilidade, na conciliação manda o critério do equilíbrio, a aproximação humana e a busca do compromisso. Mais que os problemas formais e de organização processual, o debate se concentra e focaliza o conflito humano. [...]. A sensação final será a de que todos obtiveram ganhos: a vítima se sente 'menos vítima' e o autor do delito, humanizado diante da vítima, 'menos ofensor'. A melhora do clima social 
O consenso, todavia, não pode prestar-se indiscriminadamente a todas as situações possíveis no processo penal, de modo a constituir-se um modelo processual único e exclusivo. Dentre os inconvenientes de tal hipótese, acha-se a necessidade de coação para sua subsistência. Assim, estar-se-ia diante de um consensualismo forçado, cuja ausência de voluntariedade minaria a própria essência do consenso. ${ }^{610}$

Assim, RODRÍGUEZ GARCÍA chega a estabelecer requisitos para a utilização de um modelo de consenso, a saber: a) o estrito controle judicial, que busca alcançar o equilíbrio entre as partes e evitar os riscos de privatização/mercantilização do processo penal; b) a sujeição ao império da Lei, que tem por escopo impedir a arbitrariedade na aplicação do modelo, o que poderia implicar a deturpação dos próprios fins do processo penal; c) a atenção obrigatória aos interesses da vítima, o que necessariamente resgata a atenção para esta no processo penal. ${ }^{611}$

Em razão da invocação dos interesses da vítima no parágrafo anterior, torna-se necessário esclarecer que o consenso, em suas manifestações positivadas junto aos diversos ordenamentos jurídicos, nem sempre leva em consideração os interesses daquela.

Sob tal perspectiva, GOMES refere-se especificamente a um submodelo do modelo consensuado, o modelo da Justiça criminal negociada, que teria por base o plea bargaining, ou seja, "a confissão do delito, assunção de culpabilidade, acordo sobre a quantidade da pena, incluindo a prisional, perda de bens, reparação dos danos, forma de execução da pena etc.”, que opõe a outro submodelo, o modelo pacificador ou restaurativo, "que visa à pacificação interpessoal e social do conflito, reparação dos danos à vítima, satisfação das expectativas de paz social da comunidade etc.". ${ }^{612}$

e a reabilitação serão os efeitos co-naturais à consecução de um compromisso vítima-ofensor como máxima expressão da mínima aflição na reação social ao delito.” (SANTANA, Selma Pereira de. Justiça restaurativa: a reparação como consequência jurídico-penal autônoma do delito. Rio de Janeiro: Lumen Juris, 2010, p. 169).

610 "As coisas passar-se-iam aqui em termos homólogos aos duma sociedade ideologicamente construída em termos de consensualidade pura. E cujos perigos o sociólogo Dahrendorf tem, entre outros, posto persistentemente em evidência. Nas representações do autor, para além de não conhecer a alienação e o domínio, uma sociedade de consenso não conheceria igualmente a mudança e a inovação. No imobilismo de sua a-historicidade, ela só se distinguiria de um cemitério, na medida em que nela, apesar de tudo, sempre 'ocorreriam certas coisas'. Acresce, sobretudo, que tal projeção utópica só seria imaginável se coactivamente imposta. Pois, sublinha, uma sociedade de consenso puro só seria possível à custa da polícia política." (ANDRADE, Manuel da Costa. Consenso e oportunidade. In: Jornadas de direito processual: o novo código de processo penal. Lisboa: C.E.J., 1989, p. 319-358, p. 330).

${ }^{611}$ RODRIGUEZ GARCIA, Nicolás. Análisis de la nueva regulación del 'principio del consenso' en el procedimiento abreviado español. In: COSTA ANDRADE, Manuel da et al. (Org.). Liber discipulorum para Jorge de Figueiredo Dias. Coimbra, Coimbra Editora, 2003, p. 1455-1500, p. 1467.

612 GOMES, Luiz Flávio. Justiça penal restaurativa: conciliação, mediação e negociação. Disponível em: $<$ http://www.universojuridico.com.br/publicacoes/doutrinas/3880/JUSTICA_PENAL_RESTAURATIVA_C ONCILIACAO_MEDIACAO_E_NEGOCIACAO>. Acesso em: 28 abr. $20 \overline{1} 1$. 
Dentro de tal distinção efetuada por GOMES, deve-se ressaltar que o aludido modelo negociado, alheio à participação da vítima, parece cuidar-se tão-somente de um mecanismo para deflação processual sem quaisquer pretensões em relação à dignidade das vítimas, o que não interessa aos escopos do presente trabalho ${ }^{613}$.

Nesse contexto, também não se pode olvidar que o modelo de consenso não goza de pacífica aceitação. Críticas como a de que tal modelo implicaria flexibilização de direitos tradicionais em prol de um eficientismo, e de que redundaria em uma nociva privatização do processo penal, dentre outras, são frequentemente invocadas pelos opositores do consensualismo no processo penal, chegando VILLAR a apontar que o consensualismo constitui um dos indicativos da patologia mental de dupla personalidade que está a acometer a justiça penal. ${ }^{614}$

Não cabendo aqui uma análise mais aprofundada acerca de tais críticas, podese, contudo, afirmar que os questionamentos levantados não podem ser desprezados, antes devem mesmo ser tomados em consideração para o aperfeiçoamento de qualquer modelo de processo penal.

Por fim, cumpre ressaltar que, antes mesmo de cuidar-se de um mero mecanismo de desobstrução da justiça penal em face da inflação penal e processual, a diversão pelo consenso possibilita, no âmbito do processo penal, a instalação de um espaço bem mais adequado do que os institutos tradicionais então em voga ${ }^{615}$ para o enfrentamento da vitimização secundária e para o atendimento aos interesses das vítimas de infração penal.

\subsubsection{A vítima e o consenso: o estabelecimento de um direito}

Consoante referido ao término do item anterior, o consenso representa para a vítima um notável avanço dentro do modelo clássico de processo penal continental.

\footnotetext{
${ }^{613}$ GOMES, Luiz Flávio. Justiça penal restaurativa: conciliação, mediação e negociação. Disponível em: <http://www.universojuridico.com.br/publicacoes/doutrinas/3880/JUSTICA_PENAL_RESTAURATIVA_C ONCILIACAO_MEDIACAO_E_NEGOCIACAO>. Acesso em: 28 abr. 2011.

${ }^{614}$ VILAR, Silvia Barona. Seguridad, celeridade y justicia penal. Valencia: Tirant lo Blanch, 2004, p. 191192.

${ }^{615}$ De fato, os institutos tradicionais de amparo à vítima, disponíveis no modelo clássico, como a ação civil, a adesão civil, e mesmo a atuação de colaborador com o acusador público, além de pecar, em regra, por uma cisão de interesses da vítima (interesses penais e cíveis), não proporcionam uma resposta de caráter mais imediato e efetivo, como se oportuniza no modelo de consenso.
} 
Resgatada de seu tradicional alheamento do processo penal e livre de uma participação meramente formal, destituída de maior importância, pelo consenso, a vítima torna-se protagonista processual. Seus interesses, suas expectativas e, acima de tudo, sua vontade são imprescindíveis para a formação de um acordo e para o desfecho do processo em andamento. ${ }^{616}$

Nessa perspectiva, refere-se aqui a um verdadeiro direito à solução consensual do processo, como desdobramento do necessário reconhecimento da dignidade da vítima no processo penal. De fato, em nome dessa dignidade, deve o ordenamento jurídico estipular espaços para juízos de discricionariedade, em que seja possível o consenso entre as partes, incluindo-se necessariamente a vítima, que deverá, assistida juridicamente, participar com o acusado de tratativas visando a um desfecho consensual do caso.

Deve-se deixar bem claro que o consenso já se encontra incorporado ao ordenamento jurídico processual penal brasileiro. Como é sabido, a Constituição Federal de 1988, em seu art. 98, inciso I, instituiu os Juizados Especiais Criminais. ${ }^{617}$ Mais do que isso, tal dispositivo representou uma verdadeira e notável quebra de paradigma no processo penal brasileiro.

De fato, ao lado do princípio da legalidade, que conta com tradicional acolhida no ordenamento jurídico nacional, passou-se a prever a possibilidade de transação, possibilitando-se a instituição de um espaço específico para o juízo de discrionariedade no processo penal.

Rompendo com o dogma de um modelo processual penal único, o Constituinte entendeu por permitir uma dualidade no processo penal brasileiro, mediante a convivência harmônica de dois modelos processuais: o modelo clássico, constituído como modelo padrão, e o modelo consensual, restrito às infrações de pequeno potencial ofensivo, que mereceu regramento a partir da Lei n. 9.099/95.

Entenda-se que essa incorporação do consenso no processo penal brasileiro, levada a cabo pelo Constituinte de 1988 (art. 98, I), não pode olvidar a participação da

\footnotetext{
${ }^{616}$ Exclui-se aqui, portanto, o consenso sem a participação da vítima, encetado apenas por acusador público e acusado.

617 "Art. 98. A União, no Distrito Federal e nos Territórios, e os Estados criarão: I - juizados especiais, providos por juízes togados, ou togados e leigos, competentes para a conciliação, o julgamento e a execução de causas cíveis de menor complexidade e infrações penais de menor potencial ofensivo, mediante os procedimentos oral e sumariíssimo, permitidos, nas hipóteses previstas em lei, a transação e o julgamento de recursos por turmas de juízes de primeiro grau". Sobre os antecedentes e o contexto em que se deu referida instituição, inclusive, a colaboração da Professora Ada Pellegrini Grinover, consultar: TOURINHO FILHO, Fernando da Costa. Comentários à lei dos juizados especiais criminais. 7. ed. São Paulo: Saraiva, 2010, p. 11-19.
} 
vítima, pois os institutos consensuais não podem beneficiar somente o acusado, mas também as vítimas da infração penal, sob pena de se violar o ideal de isonomia que deve reger as relações processuais.

Assim, do próprio art. 98, inciso I, da Constituição Federal de 1988, sob uma leitura isonômica do processo, sem se olvidar o respaldo principiológico da Dignidade da Pessoa Humana, também aplicável às vítimas de infração penal, pode-se depreender o direito da vítima à solução consensual do processo penal.

Esse direito, como já referido, não pode ser generalizado e aplicado a todas as situações processuais indistintamente, devendo ser reservado a situações peculiares, conforme prévia orientação político-criminal, sendo frequente sua previsão em espaços de microcriminalidade, como é o caso do ordenamento jurídico brasileiro (Juizados Especiais Criminais).

Em espaços como o da criminalidade média ou mesmo da macrocriminalidade, o consenso mediante a participação da vítima também pode ser levado em conta, mas não como condição para extinção do processo, podendo, em tais hipóteses, consistir em condição para a redução de pena eventualmente imposta ou mesmo para a substituição de pena privativa de liberdade por pena restritiva de direitos.

Além das vantagens manifestas trazidas à vítima, não se pode negar também que o consenso traga grandes benesses para o próprio acusado, que também é guindado a uma condição de protagonista, já que o consenso depende igualmente de sua vontade, e tem a oportunidade de expor seu ponto de vista e de tomar ciência direta das consequências de sua conduta, possibilitando-se uma maior conscientização de sua parte, a par de consistir em fator de redução da estigmatização que o processo penal costuma trazer em benefício do acusado.

\subsubsection{A vítima e os institutos consensuais no atual processo penal brasileiro}

Dada a incorporação do consenso no ordenamento jurídico brasileiro pela Constituição Federal de 1988, implementada pela Lei n. 9.099/95, resta identificar, neste azo, os atuais institutos consensuais disponíveis com enfoque especial sobre a possibilidade de participação da vítima na formação do consenso. 
O processo penal brasileiro, basicamente, prevê a existência de três institutos consensuais: a composição civil de danos e a transação penal, aplicáveis tão somente no âmbito dos Juizados Especiais Criminais, portanto, para infrações penais de pequeno potencial ofensivo (cuja pena privativa de liberdade abstrata não ultrapasse dois anos), e a suspensão condicional do processo, aplicável a infrações penais cuja pena privativa abstrata mínima seja inferior ou igual a um ano.

A composição civil de danos encontra-se prevista nos arts 73 e 74, da Lei n. 9.099/95. Aberta a audiência preliminar, com a presença do membro do Ministério Público, o autor do fato, a vítima e, se possível, o responsável civil, acompanhados de seus advogados, o juiz esclarecerá acerca da possibilidade de composição civil de danos, que poderá ser conduzida pelo próprio juiz ou por conciliador.

Esse instituto tem por objeto a solução do conflito de natureza civil existente entre as partes (vítima e autor do fato), decorrente da prática do fato tido por infração penal, oportunizada no âmbito do processo penal. Vale lembrar que durante esse momento processual, o juiz desempenha os bons ofícios conciliatórios, não atuando propriamente na atividade de julgar, zelando pelo equilíbrio na negociação, cabendo ao Ministério Público a fiscalização do ato.

Celebrada a composição e uma vez homologada pelo juiz, serão produzidos efeitos jurídicos em matéria civil e em matéria penal. Em matéria civil, a sentença homologatória servirá como título executivo judicial, contudo não está claro se o acordo produz coisa julgada no cível ou não. ${ }^{618}$

Em matéria penal, a Lei empresta à composição civil de danos os seguintes efeitos: em se tratando de ação penal de iniciativa privada ou de ação penal pública condicionada à representação, a homologação do acordo enseja a renúncia ao direito de queixa ou representação, extinguindo-se a punibilidade; sob um prisma processual estrito, tal homologação obsta o exercício da ação penal, ainda que haja descumprimento posterior da composição avençada entre as partes. ${ }^{619}$

\footnotetext{
618 “Também, não está claro se o acordo cível na esfera criminal produz coisa julgada no âmbito cível. Por sua natureza eminentemente dispositiva, de direito disponível, penso que as partes não poderão discutir mais a responsabilidade civil nem sua quantia no juízo cível. Em princípio, o acordo cível implica quitação recíproca, sem prejuízo de esta ser parcial, com reserva da discussão no âmbito cível (quitação dos danos patrimoniais, com ressalva dos morais)". (GIACOMOLLI, Nereu José. Legalidade, oportunidade e consenso no processo penal na perspectiva das garantias constitucionais: Alemanha, Espanha, Itália, Portugal e Brasil. Porto Alegre: Livraria do Advogado, 2006, p. 322).

${ }^{619}$ Apesar de tal eficácia referir-se somente a hipóteses de ação penal de iniciativa pública condicionada à representação e de ação penal de iniciativa privada, nada impede que seja oportunizada a composição civil de danos em ações penais de iniciativa pública incondicionada, a fim de, em honra à celeridade e aos interesses da vítima, buscar a solução do conflito civil em uma perspectiva mais imediata.
} 
Os demais institutos consensuais trazidos pela Lei n. 9.099/95, deve-se de já advertir, não contam com a necessária participação da vítima. A transação penal, por exemplo, prevista no art. 76, será cabível em caso de não realização da composição civil de danos (em se tratando de ação penal de iniciativa privada ou de ação penal pública condicionada à representação).

A avença que constitui objeto da transação penal somente pode ser celebrada entre o Ministério Público e o autor do fato, podendo aquele propor a aplicação imediata de pena restritiva de direitos ou multas, a ser especificada na proposta.

Para tanto, a própria Lei n. 9.099/95, em seu art. 76, §2 , estipula como requisitos: a) não ter sido o autor da infração condenado, pela prática de crime, à pena privativa de liberdade, por sentença definitiva; b) não ter sido o agente beneficiado anteriormente, no prazo de cinco anos, pela aplicação de transação penal; c) se os antecedentes, a conduta social e a personalidade do agente, bem como os motivos e as circunstâncias, indicarem tratar-se de medida necessária e suficiente.

Importante ressaltar que essa modalidade de consenso não implica reconhecimento de culpa pelo autor do fato, não devendo constar em certidão de antecedentes criminais, conforme a própria Lei n. 9.099/95, art. 76, §6º

A suspensão condicional do processo (sursis processual), por sua vez, prevista na Lei n. 9.099/95, art. 89, diferenciando-se dos demais institutos, pressupõe o ajuizamento de ação penal pelo Ministério Público. Envolve uma proposta de suspensão processual (bem como suspensão da prescrição), pelo período de dois a quatro anos, trazida pelo Ministério Público, desde que o acusado não esteja sendo processado ou não tenha sido condenado por outro crime, e uma vez presentes os demais requisitos que autorizariam a suspensão condicional da pena (art. 77, do Código Penal).

O $\S 1^{\circ}$, do art. 89 estipula que, uma vez aceita a proposta pelo acusado e seu defensor, na presença do juiz, este, recebendo a denúncia, poderá suspender o processo, submetendo o acusado a período de prova, sob as seguintes condições: a) reparação do dano, salvo impossibilidade de fazê-lo; b) proibição de frequentar determinados lugares; c) proibição de ausentar-se da comarca onde reside, sem autorização do Juiz; d) comparecimento pessoal e obrigatório a juízo, mensalmente, para informar e justificar suas atividades, bem como de outras condições fixadas pelo juiz, desde que adequadas ao fato e à situação pessoal do acusado $\left(\operatorname{art} .89, \S 2^{\circ}\right)$. 
Dentre as condições expressamente previstas, destaca-se a imposição da reparação do dano à vítima, o que, à primeira vista, parece bem atender aos interesses da vítima, não sendo de todo verdadeiro, contudo.

De fato, o consenso pela suspensão do processo prescinde da participação da vítima, tratando-se de ato a ser celebrado exclusivamente entre o Ministério Público e o acusado, e submetido à chancela judicial.

Com tal prescindibilidade, a vítima, muitas vezes, sequer é intimada a participar da audiência admonitória para proposição do acordo. O dano efetivo ao seu patrimônio sequer é avaliado, não sendo possível precisá-lo ainda que por estimativa. E para agravamento da situação, o Ministério Público não tem legitimidade para representar os interesses patrimoniais daquela, visto estes revestirem natureza individual e disponível.

Em face de tais circunstâncias, a condição de reparação do dano é facilmente ignorada sob a utilização indevida do fundamento genérico de impossibilidade de reparação, e, quando observada, pode limitar-se a uma reparação insuficiente e distante do verdadeiro quantum devido.

Em verdade, sob a regulamentação atual, a suspensão condicional do processo está longe de consistir um mecanismo útil aos interesses da vítima, podendo mesmo resultar em frustração e até em fator de vitimização secundária.

$\mathrm{Na}$ verdade, o consenso atualmente disponibilizado no processo brasileiro está a merecer algumas alterações a fim de ensejar um atendimento aos interesses das vítimas. Assim, pode-se, por exemplo, partir de uma reformulação simples da suspensão condicional do processo, a fim de que a vítima, juntamente com o Ministério Público e o acusado, seja protagonista do acordo, ${ }^{620}$ e não somente eventual beneficiária indireta, criando-se expectativas que dificilmente poderão ser bem correspondidas.

A imprescindibilidade na participação da vítima por ocasião da formação do acordo, decorrente de dispositivo legal permitiria que a própria vítima, assistida por advogado, tratasse diretamente de seus interesses, que não precisariam ser discutidos por sujeitos processuais outros, que já dispõem de seus próprios interesses a defender em juízo.

Outra modificação favorável aos interesses da vítima seria a possibilidade de extensão do mecanismo da composição civil de danos a infrações penais para fora do âmbito dos Juizados Especiais Criminais, nos casos de crimes patrimoniais que não envolvessem violência ou grave ameaça (furto, receptação, estelionato etc.), os quais

\footnotetext{
${ }^{620}$ A suspensão provisória do processo, prevista no Código de Processo Penal português, (arts. 281 e 282), tem como pressuposto a concordância do arguido (acusado) e do assistente (art. 281, 1, a).
} 
poderiam passar a ensejar o manejo de ação penal de iniciativa pública condicionada à representação.

Tais soluções, é claro, não poderiam prescindir de alterações legais na atual configuração legal do processo penal brasileiro.

\subsection{JUSTIÇA RESTAURATIVA: UMA BREVE APRESENTAÇÃO}

\subsubsection{Noções e princípios}

O estudo do consenso no processo penal torna obrigatória uma abordagem, ainda que de caráter geral, sobre a justiça restaurativa.

Práticas típicas de sociedades comunais ou pré-estatais, em que os interesses coletivos se sobrepõem aos interesses individuais, aliadas a fatores outros - como o movimento vitimológico -, ensejaram o desenvolvimento de modelos de justiça restaurativa. ${ }^{621}$

${ }^{621}$ JACCOUD apresenta um interessante relato acerca da origem e dos precursores do movimento de justiça restaurativa, que pedimos vênia para transcrever na íntegra: "Em virtude de seu modelo de organização social, as sociedades comunais (sociedades pré-estatais européias e as coletividades nativas) privilegiavam as práticas de regulamento social centradas na manutenção da coesão do grupo. Nestas sociedades, onde os interesses coletivos superavam os interesses individuais, a transgressão de uma norma causava reações orientadas para o restabelecimento do equilíbrio rompido e para a busca de uma solução rápida para o problema. Embora as formas punitivas (vingança ou morte) não tenham sido excluídas, as sociedades comunais tinham a tendência de aplicar alguns mecanismos capazes de conter toda a desestabilização do grupo social. Os vestígios destas práticas restaurativas, reintegradoras, cons e negociáveis se encontram em muitos códigos decretados antes da primeira era cristã. Por exemplo, o código de Hammurabi (1700 a.C. ) e de Lipit-Ishtar (1875 a.C.) prescreviam medidas de restituição para os crimes contra os bens. O código sumeriano (2050 a.C.) e o de Eshunna (1700 a.C.) previam a restituição nos casos de crimes de violência (Van Ness e Strong, 1997). Elas podem ser observadas também entre os povos colonizados da África, da Nova Zelândia, da Áustrália, da América do Norte e do Sul, bem como entre as sociedades pré-estatais da Europa. O movimento de centralização dos poderes (principalmente pelo advento das monarquias de direito divino) e o nascimento das nações e dos estados modernos vão reduzir consideravelmente estas formas de justiça negociada. O nascimento do Estado coincide com o afastamento da vítima no processo criminal e com a quase extinção das formas de reintegração social nas práticas de justiça habitual (Dupont-Bouchât, 1999). Nos territórios colonizados, tornou-se necessário a criação de nações-estado pelos colonizadores, para a neutralização das práticas habituais através da imposição de um sistema de direito único e unificador (Jaccoud, 1992). Apesar desta imposição, não foram completamente extintas as práticas tradicionais de resolução dos conflitos destas sociedades. Aliás, o ressurgimento contemporâneo dos modelos restaurativos nos estados formados durante um processo de colonização está em parte ligado aos movimentos reivindicatórios dos povos nativos, que demandaram que a administração da justiça estatal respeitasse suas concepções de justiça (Jaccoud, 1999), mas também os problemas endêmicos de superpopulação dos nativos nos estabelecimentos penais e sócio-protetivos. Por outro lado, seria errôneo fingir, como alguns o fazem, que a justiça restaurativa tenha se originado das práticas tradicionais dos povos nativos. Os vestígios de uma 
Sobre o tema, deve-se ressaltar que não existe uma definição pronta e acabada do que seja justiça restaurativa. ${ }^{622} \mathrm{Na}$ verdade, trata-se de uma área em que vicejam

justiça direcionada para o reparo não são apêndice exclusivo dos povos nativos, mas o das sociedades comunais em geral. As práticas restaurativas das sociedades comunais e pré-estatais controladas estão mais ligadas à estrutura social que à cultura. Outros fatores encorajaram o aparecimento do modelo da justiça restaurativa. Faget (1997) sustenta que três correntes de pensamento favoreceram o ressurgimento da justiça restaurativa e dos processos que a ela estão associados (em particular a mediação) nas sociedades contemporâneas ocidentais: trata-se dos movimentos 1) de contestação das instituições repressivas, 2) da descoberta da vítima e 3) de exaltação da comunidade. O movimento de contestação das instituições repressivas surgiu nas universidades americanas e foi fortemente marcado pelos trabalhos da escola de Chicago e de criminologia radical que se desenvolvem na universidade de Berkeley na Califórnia. Este movimento inicia uma crítica profunda das instituições repressivas, destacando principalmente seu papel no processo de definição do criminoso. Ele retoma, entre outras, a idéia durkheimiana, segundo a qual o conflito não é uma divergência da ordem social, mas uma característica normal e universal das sociedades. Nos Estados Unidos, alguns movimentos confessionais (sobretudo os Quakers e o Mennonites) se unem à corrente da esquerda radical americana para contestar o papel e os efeitos das instituições repressivas. $\mathrm{O}$ movimento crítico americano encontra eco na Europa onde os trabalhos de Michel Foucault (Surveiller et punir: naissance de la prison, 1975), Françoise Castel, Robert Castel e Anne Lovell (La société psychiatrique avancée: le modèle américain,1979), Nils Christie (Limits to Pain, 1981) e Louk Hulsman (Peines perdues: le système pénal em question, 1982) nutrem a reflexão e o desenvolvimento de um movimento que recomenda o recurso para uma justiça diferente, humanista e não punitiva. No término da Segunda Guerra Mundial, como lembra Faget, surge e se desenvolve um discurso de cunho científico sobre as vítimas, a vitimologia. Este conhecimento vai primeiramente, na pura tradição positivista que caracteriza a criminologia da época, se preocupar com as razões da vitimização, tentar identificar os fatores que predispõem os indivíduos a tornarem-se vítimas. $\mathrm{O}$ interesse para as consequências da vitimização é mais tardio. Os lobbies vitimistas ligados e apoiados pelos sábios discursos sobre a vítima vão sensibilizar profundamente os críticos teóricos do modelo retributivo para as necessidades, mas sobretudo para a ausência da vítima no processo penal. O movimento vitimista inspirou a formalização dos princípios da justiça restaurativa, mas não endossou seus princípios nem participou diretamente de seu advento. É necessário, então, manter prudência na análise das relações que o movimento vitimista mantém com a justiça restaurativa. Finalmente, um movimento que faz a promoção das virtudes da comunidade, o que Faget nomeia de exaltação da comunidade, inspira a justiça restaurativa. O princípio da comunidade é valorizado como o lugar que recorda as sociedades tradicionais nas quais os conflitos são menos numerosos, melhor administrados e onde reina a regra da negociação". (JACCOUD, Mylène. Princípios, tendências e procedimentos que cercam a justiça restaurativa. In: SLAKMON, Catherine; DE VITTO, Renato Campos Pinto; PINTO, Renato Sócrates Gomes. (Org.). Justiça restaurativa. Brasília-DF: Ministério da Justiça e Programa das Nações para o Desenvolvimento - PNUD, 2005, p. 163-186, p. 163-165).

${ }^{622}$ "A denominação justiça restaurativa é atribuída a Albert Eglash, que em 1977, escreveu um artigo intitulado Beyond Restitution: Creative Restitution, publicado numa obra por Joe Hudson e Burt Gallaway, denominada 'Restitution in Criminal Justice' (Van Ness e Strong, 2002:27). Eglash sustentou, no artigo, que havia três respostas ao crime - a retributiva, baseada na punição; a distributiva, focada na reeducação; e a restaurativa, cujo fundamento seria a reparação." (PINTO, Renato Sócrates Gomes. A construção da justiça restaurativa no Brasil: impacto no sistema de justiça criminal. Disponível em: $<$ http://www.idcb.org.br/documentos/sobre\%20justrestau/construcao_dajusticarestaurativanobrasil2.pdf $>$. Ac esso em: 25 abr. 2011, p. 3). Após a definição inicial de EGLASH, “[...] em 1990, Horwitz publica um trabalho no qual apresenta quatro estilos principais de controle social, cada um centrado em prejuízos, responsabilidades, metas e soluções específicas. No mesmo ano, H. Zehr publica, Changing Lenses, um livro decisivo na eclosão da justiça restaurativa como paradigma que marca uma ruptura com o modelo retributivo. Neste livro, que tornou-se um clássico, Zehr sugere a existência de dois modelos de justiça fundamentalmente diferentes: o modelo retributivo e o modelo restaurador. Alguns anos depois, L. Walgrave (1993) propõe uma síntese, que ainda hoje é referência freqüente para a definição da justiça restaurativa. De acordo com este autor, a justiça é marcada por três tipos principais de direito: o direito penal, o reabilitador e o direito restaurativo." (JACCOUD, Mylène. Princípios, tendências e procedimentos que cercam a justiça restaurativa. In: SLAKMON, Catherine; DE VITTO, Renato Campos Pinto; PINTO, Renato Sócrates Gomes. (Org.). Justiça restaurativa. Brasília-DF: Ministério da Justiça e Programa das Nações para o Desenvolvimento - PNUD, 2005, p. 163-186, p. 163-168). A referida autora cita o modelo de WALGRAVE, que distingue Direito Penal, Direito Reabilitador e Direito Restaurador, o qual ora se reproduz da seguinte forma: 
concepções, instrumentos e técnicas diversas, que podem desenvolver-se dentro do âmbito estatal ou mesmo fora deste, podendo contar com uma maior ou menor participação de atores sociais, como a vítima, o ofensor, ${ }^{623}$ familiares, vizinhança, entidades comunitárias, ONG's etc.

Com o propósito de se firmar algum delineamento desse modelo, para o momento, propõe-se uma ligeira referência a seus princípios básicos, tal qual referidos na Resolução n. 2002/12, do Conselho de Desenvolvimento Econômico e Social da ONU. ${ }^{624}$

O texto da resolução referida fala de programas e processos de justiça restaurativa, entendidos estes últimos como quaisquer processos em que a vítima e o ofensor, e, quando conveniente, quaisquer outros indivíduos ou membros da comunidade afetados por um delito, participam de forma conjunta e ativa, na resolução de questões decorrentes do delito, em geral com o auxílio de um facilitador. Os processos restaurativos podem incluir mediação, conciliação, conferências (reuniões coletivas) e círculos de sentenças. $^{625}$

\begin{tabular}{|c|c|c|c|}
\hline & DIREITO PENAL & $\begin{array}{c}\text { DIREITO } \\
\text { REABILITADOR }\end{array}$ & $\begin{array}{c}\text { DIREITO } \\
\text { RESTAURADOR }\end{array}$ \\
\hline Ponto de referência & Delito & Indivíduo delinquente & Prejuízos causados \\
\hline Meios & Aflição de dor & Tratamento & Obrigação para restaurar \\
\hline Objetivos & Equilíbrio moral & Adaptação & Anulação dos erros \\
\hline Posição das vítimas & Secundário & Secundário & Central \\
\hline Critérios de avaliação & "Pena adequada" & Indivíduo adaptado & $\begin{array}{c}\text { Satisfação dos } \\
\text { interessados }\end{array}$ \\
\hline Contexto social & Estado opressor & Estado providência & Estado responsável \\
\hline
\end{tabular}

${ }^{623} \mathrm{O}$ suposto autor do fato (vitimário).

${ }^{624}$ Eis seu preâmbulo: "Considerando que tem havido um significativo aumento de iniciativas com justiça restaurativa em todo o mundo; Reconhecendo que tais iniciativas geralmente se inspiram em formas tradicionais e indígenas de justiça que vêem, fundamentalmente, o crime como danoso às pessoas; Enfatizando que a justiça restaurativa evolui como uma resposta ao crime que respeita a dignidade e a igualdade das pessoas, constrói o entendimento e promove harmonia social mediante a restauração das vítimas, ofensores e comunidades; Focando o fato de que essa abordagem permite que as pessoas afetadas pelo crime possam compartilhar abertamente seus sentimentos e experiências, bem assim seus desejos sobre como atender suas necessidades; Percebendo que essa abordagem propicia uma oportunidade para as vítimas obterem reparação, se sentirem mais seguras e poderem superar o problema, permite os ofensores compreenderem as causas e conseqüências de seu comportamento e assumir responsabilidade de forma efetiva, bem assim possibilita à comunidade a compreensão das causas subjacentes do crime, para se promover o bem estar comunitário e a prevenção da criminalidade; Observando que a justiça restaurativa enseja uma variedade de medidas flexíveis e que se adaptam aos sistemas de justiça criminal e que complementam esses sistemas, tendo em vista os contextos jurídicos, sociais e culturais respectivos; Reconhecendo que a utilização da justiça restaurativa não prejudica o direito público subjetivo dos Estados de processar presumíveis ofensores."

${ }^{625} \mathrm{Na}$ mediação, o mediador se põe entre as partes em busca de soluções para os conflitos; a conciliação se mostra em um nível mais adiantado, já que o conciliador não se limita a facilitar o diálogo entre vítima e ofensor, facultando-se-lhe apresentar sugestões para a resolução do conflito. Quanto às conferências (reuniões coletivas) e aos círculos de sentença, MOLINO faz a distinção: "Reunião coletiva (conferencing): existirá um diálogo de modo amplo discutido também origens e conseqüências da conduta delitiva projetando uma reparação, mas de modo coletivo, saindo da esfera individual. [...] Círculos decisórios (sentencing 
Sob o tópico Utilização de programas de justiça restaurativa (itens 6 a 11), o documento referido destaca alguns aspectos importantes.

Primeiramente, no item 6, aduz que os programas de justiça restaurativa poderão ser utilizados em qualquer fase do sistema de justiça penal, de acordo com a legislação nacional, o que afasta, a princípio, a autorregulação social pura e simples. ${ }^{626}$

Exige-se, ademais, para o processo restaurativo, a existência de elementos de prova suficientes para o oferecimento de acusação contra o ofensor.

Impõem-se ainda os princípios do voluntarismo e da consensualidade. Sob a ótica do primeiro, veda-se a imposição de uma solução estatal, já que esta deve brotar da vontade das partes (vítima e ofensor), ${ }^{627}$ sob o prisma da consensualidade, por sua vez, busca-se uma solução que dependa do consenso entre os envolvidos, devendo-se assegurar condições favoráveis para se estabelecer o processo comunicacional (diálogo) entre aqueles, ${ }^{628}$ destacando-se ainda que tal consenso deve pautar-se no respeito ao equilíbrio.

Os itens 12 a 19, reunidos sob o tópico Operação dos programas restaurativos, preveem, dentre outros, o princípio da confidencialidade.

Por esse princípio, assegura-se aos participantes que as tratativas que envolvem

circles): são estabelecidos círculos envolvendo determinado grupo de pessoas relacionadas com o problema e começa o diálogo do mesmo modo que os processos anteriores, vislumbrando-se as origens e conseqüências visando reparar ou minimizar os danos e traumas causados. Os dois últimos processos se assemelham muito, já que envolve o coletivo, tratando de discussões reflexivas e amplas, saindo de temas específicos, sendo que a maior diferença entre os dois consiste na sua formação, já que nas reuniões coletivas são dispostos vítimas e infratores em pólos opostos tendo como divisor os mediadores, já no caso dos círculos, vítimas, infratores e mediadores estão num mesmo plano. Um exemplo de cada tipo seria as reuniões de moradores de pequenas comunidades canadenses afetadas por problemas de vandalismo para o caso de reuniões coletivas; os círculos são amplamente utilizados no setor educacional, sendo amplamente utilizado em escolas para discutir problemas entre alunos." (MOLINO, Fernanda Brusa. Justiça Restaurativa: possibilidade ou utopia? Âmbito Jurídico, Rio Grande, 71, 01 fev. 2009. Disponível em: <http://www.ambitojuridico.com.br/site/index.php?n_link=revista_artigos_leitura\&artigo_id=6689>. Acesso em 18 abr. 2011).

${ }^{626}$ FERREIRA apresenta quatro formas distintas de regulação de conflitos, tendo por critério a interferência estatal: a) autorregulação pura e simples; b) autorregulação social enquadrada por normação estatal; c) regulação estatal com incorporação de elementos de autorregulação; d) regulação estatal imperativa: (FERREIRA, Francisco Amado. Justiça restaurativa: natureza, finalidade e instrumentos. Coimbra: Coimbra Editora, 2006, p. 23).

627 FERREIRA, neste ponto, questiona qualquer forma de imposição, pelo Estado, de mecanismos restaurativos, como, por exemplo, o estabelecimento obrigatório de uma fase prévia com fins restaurativos (pre-trial intervention). Aduz o autor que " [...] ao tornarmos o processo restaurativo obrigatório, poderemos estar a convertê-lo num acto inútil e traduzível num puro desperdício de tempo e de recursos ou, então, a aumentarmos os riscos de as partes celebrarem o acordo 'a qualquer preço' ou mesmo a serem manipuladas e, concomitantemente, incrementarmos a sua sensação de insatisfação e uma maior tendência para o incumprimento dos acordos homologados." (FERREIRA, Francisco Amado. Justiça restaurativa: natureza, finalidade e instrumentos. Coimbra: Coimbra Editora, 2006, p. 31-32).

628 "O princípio do consenso exige, primeiro, respeito entre as partes e pelas partes, novamente com observância da ética da solidariedade. O rompimento com o distanciamento social a que parece todos estarem condenados na pós-modernidade só se faz com o diálogo e, dentro da justiça penal, o mesmo é apresentado como valor irrenunciável para a pacificação do conflito social.” (SALIBA, Marcelo Gonçalves. Justiça restaurativa e paradigma punitivo. Curitiba: Juruá, 2009, p.154). 
a celebração de um eventual acordo não serão tornadas públicas, não se podendo, inclusive, reduzi-las a termo, ressalvadas a vontade das próprias partes e disposições legais.

Isso porque tais tratativas importam tão-somente ao processo restaurativo, não podendo ser utilizadas para formação da convicção do julgador, a este não devendo ser dada ciência sobre seu teor. Tal ambiente mais restrito assegura maior abertura e disponibilidade das partes por ocasião dessas tratativas.

O documento sob análise refere-se também ao princípio da complementaridade, ao dispor que em face da inexistência de acordo entre as partes, o caso deverá retornar ao procedimento convencional da justiça criminal, o que não pode ser invocado em prejuízo das partes (item 16).

Denota-se, assim, que a justiça restaurativa não se propõe como substitutivo da justiça convencional, na verdade, ser-lhe-ia complementar.

Segundo FERREIRA, a incidência da justiça restaurativa dá-se especialmente em determinadas matérias, como as que envolvem maior vulnerabilidade, como é o caso da justiça penal juvenil, ou em casos de delinquência de interconhecimento, a saber, quando já existe uma relação entre vítima e ofensor prévia ao cometimento do delito. ${ }^{629}$

Alude o autor também a uma concepção mais alargada para a qual a cura constitui o maior objetivo, suplantando a própria reparação, em que o modelo restaurativo pode ser utilizado em qualquer tipo de criminalidade.

Sob tal ótica, em infrações de pequena gravidade, o acordo pode extinguir o processo, ao passo que em infrações de maior gravidade, a celebração daquele poderá implicar a redução de pena eventualmente imposta por ocasião de uma condenação. ${ }^{630}$

Uma vez analisados os princípios referidos na Resolução n. 2002/12, do Conselho de Desenvolvimento Econômico e Social da ONU, tome-se o modelo sugerido por SAMPEDRO ARRUBLA, que se aplica ao conceito de justiça restaurativa.

Mencionado autor ressalta três características desse novo modelo de justiça. ${ }^{631}$

Primeiramente, deve o processo ser comunicativo. Em lugar da visão de combate entre os adversários (ofensor e vítima), propõe-se uma perspectiva de diálogo,

${ }^{629}$ FERREIRA, Francisco Amado. Justiça restaurativa: natureza, finalidade e instrumentos. Coimbra: Coimbra Editora, 2006, p. 26 e 123.

${ }^{630}$ FERREIRA, Francisco Amado. Justiça restaurativa: natureza, finalidade e instrumentos. Coimbra: Coimbra Editora, 2006, p. 38-40.

${ }^{631}$ Conferir exposição completa do autor, utilizada neste texto, sobre as três características do novo modelo: SAMPEDRO ARRUBLA, Júlio Andrés. Pensar el processo penal. El principio de oportunidad, un instrumento para la humanización del processo desde las víctimas. Cuadernos de doctrina y jurisprudencia penal: criminologia, teoría y praxis, Buenos Aires, v. 1, n. 1, p. 99-117, 2002, p. 103-108. 
tendente à conciliação como forma de garantir futura convivência em paz. Esse diálogo deve-se dar entre o ofensor e a vítima, de modo que esta direta e pessoalmente transmita àquele o conhecimento das consequências de sua conduta.

Deve haver espaço também para o diálogo entre a vítima e a sociedade, de modo a firmar-se uma relação de solidariedade para com aquela que teve sua dignidade violada.

No âmbito dessa característica, também deve ser implementado o diálogo entre o ofensor e a sociedade, a fim de que esta possa captar sua parcela de responsabilidade na causação do delito e traçar estratégias de prevenção criminal e vitimária.

Em segundo lugar, exige-se também um processo resolutivo. Assim, deve-se buscar uma verdadeira solução do conflito, tanto para o ofensor quanto para a vítima. A prisão deixa de ser a única ou principal resposta ao delito, estimulando-se a criação de soluções distintas e mais efetivas. Realça-se a criação de mecanismos que estimulem a formação de consenso entre as partes, dentro e fora do processo.

Por fim, desponta a necessidade de um processo recriador. Parte-se, pois, de uma nova concepção, em que o processo consiste na continuação do encontro produzido pelo delito. Assim como no delito encontram-se três agentes, esses mesmos agentes devem estar presentes no processo: a vítima, exercendo um papel central; a sociedade, por seus representantes (comunidades urbanas, juízes, jurados, promotores etc.), objetivando não mais a imposição de um castigo, mas a transformação do fato delitivo em direito, em justiça; o ofensor, como colaborador das respostas a serem dadas à vítima.

Salta aos olhos que a novel justiça restaurativa, construída a partir da concepção do crime não como mera violação à lei, mas como ofensa ao(s) outro(s) e, mesmo, a si próprio, apresenta inúmeras vantagens em relação à justiça penal convencional. $^{632}$

Todavia, como bem aponta SALIBA, a justiça restaurativa ainda encontra grande resistência na literatura jurídica e junto aos operadores do Direito, que parecem preferir a inserção modelos de consenso sem maiores impactos processuais. ${ }^{633}$

\footnotetext{
632 “Em relação à Justiça 'oficial', a intervenção restaurativa permite alargar os horizontes da vítima e do agressor, ao criar-lhes uma melhor oportunidade de confissão, de arrependimento sincero, de perdão e de reconciliação. Nessa medida, a Justiça Restaurativa asperge propriedades curativas ou restauradoras e reconstrutivas que se mostram desconhecidas do sistema estadual de justiça". (FERREIRA, Francisco Amado. Justiça restaurativa: natureza, finalidade e instrumentos. Coimbra: Coimbra Editora, 2006, p. 25). 633 "Em que pese os argumentos favoráveis e a crise do sistema penal, a justiça restaurativa encontra resistência na doutrina e entre os operadores do Direito, que, por sua vez, aceitam muito mais um modelo denominado de Justiça penal consensual, com raízes dentro da estrutura do sistema penal e sem profundas alterações principiológicas.[...] $\mathrm{O}$ paradigma restaurativo, mais amplo em relação à Justiça consensual, é um
} 


\subsubsection{O ideal de restauração e os sujeitos do processo restaurativo}

Mais do que uma organização formal em processos ditos restaurativos, o que deve caracterizar a justiça restaurativa é a identificação de um ideal específico, que bem pode ser encontrado nas finalidades dos modelos restaurativos.

JACCOUD identifica três finalidades distintas: a correção das consequências do delito, a resolução do conflito e a reconciliação das partes envolvidas, que caracterizariam três diferentes modelos restaurativos, o que permitiria a formulação da seguinte definição, a qual consegue incluir essas finalidades em caráter alternativo ${ }^{634}$ : “a justiça restaurativa é uma aproximação que privilegia toda a forma de ação, individual ou coletiva, visando corrigir as conseqüências vivenciadas por ocasião de uma infração, a resolução de um conflito ou a reconciliação das partes ligadas a um conflito". ${ }^{635}$

As noções aqui expostas sobre a justiça restaurativa permitem depreender que o ideal de restauração suplanta a ideia de uma reparação limitada subjetivamente, já que não se acha restrita apenas às vítimas de delito, bem como a de uma reparação limitada quanto a seu conteúdo, já que a restauração não se vincula apenas a uma acepção material ou patrimonial, abrangendo também suas acepções simbólica e psicológica. ${ }^{636}$

Melhor do que qualquer tentativa de definição do ideal restaurativo, propõe-se aqui uma abordagem que propicie a captação do significado em relação a cada qual dos sujeitos que participam do processo restaurativo: a vítima, o ofensor e a sociedade, a começar pela primeira.

No que concerne às vítimas, é nos modelos restaurativos que essas recebem do

plano de reação ao desvio, voltado para a cidadania e calcado na busca da reconciliação de todas as partes envolvidas no problema, "por meio da pacificação da relação social conflituosa que o originou." (destaques do autor) (SALIBA, Marcelo Gonçalves. Justiça restaurativa e paradigma punitivo. Curitiba: Juruá, 2009, p. 174).

${ }^{634}$ Referida alternatividade não afasta a possibilidade de que em determinado processo restaurativo essas finalidades possam ser verificadas cumulativamente.

${ }^{635}$ JACCOUD, Mylène. Princípios, tendências e procedimentos que cercam a justiça restaurativa. In: SLAKMON, Catherine; DE VITTO, Renato Campos Pinto; PINTO, Renato Sócrates Gomes. (Org.). Justiça restaurativa. Brasília-DF: Ministério da Justiça e Programa das Nações para o Desenvolvimento - PNUD, 2005, p. 163-186, p.169.

636 “A amplitude do processo restaurativo não fixa a reparação material dos danos como fim único ou objetivo da justiça, o que determina um rompimento do paradigma da modernidade e a superação de seus pilares, que tem no patrimonialismo, idealizado pelos ideais burgueses, o maior deles." (SALIBA, Marcelo Gonçalves. Justiça restaurativa e paradigma punitivo. Curitiba: Juruá, 2009, p. 168). 
sistema de justiça penal sua maior valorização. ${ }^{637}$

De uma situação de esquecimento, abandono, desassistência e frustração, efeitos da vitimização produzida pelo próprio paradigma penal tradicional no âmbito do processo penal (vitimização secundária), as vítimas da infração penal são guindadas a um posto central, decorrente de seu protagonismo no caso penal. Esse novo status abre-lhes perspectivas inimagináveis sob o processo penal tradicional.

Como bem destaca BRAITHWAITE, a justiça restaurativa possibilita a restauração, em prol das vítimas, de importantes aspectos como a sensação se segurança, a dignidade, a sensação de autonomia (empowerment ${ }^{638}$ ) e a harmonia baseada na confiança de ter sido feita justiça. ${ }^{639}$

Em atenção ao efeito do disempowerment, o protagonismo confere às vitimas a possibilidade de participar da construção de uma solução dialogada e não mais imposta por um terceiro estatal, à qual aquelas assistiam muitas vezes sem sequer entender o que se

${ }^{637}$ PINTO traz uma tabela comparativa acerca dos efeitos em relação à vítima, advindos da justiça retributiva e da justiça restaurativa:

\begin{tabular}{|c|l|}
\hline JUSTIÇA RETRIBUTIVA & \multicolumn{1}{c|}{ JUSTIÇA RESTAURATIVA } \\
\hline $\begin{array}{c}\text { Pouquíssima ou nenhuma consideração, ocupando } \\
\text { lugar periférico e alienado no processo. Não tem } \\
\text { participação, nem proteção, mal sabe o que se } \\
\text { passa. }\end{array}$ & $\begin{array}{l}\text { Ocupa o centro do processo, com um papel e com } \\
\text { voz ativa. Participa e tem controle sobre o que se } \\
\text { passa. }\end{array}$ \\
\hline $\begin{array}{c}\text { Praticamente nenhuma assistência psicológica, } \\
\text { social, }\end{array}$ & $\begin{array}{l}\text { Recebe assistência, afeto, restituição de perdas } \\
\text { materiais e reparação }\end{array}$ \\
\hline econômica ou jurídica do Estado & $\begin{array}{l}\text { Tem ganhos positivos. Suprem-se as necessidades } \\
\text { individuais e coletivas da vítima e comunidade }\end{array}$ \\
\hline
\end{tabular}

(PINTO, Renato Sócrates Gomes. A construção da justiça restaurativa no Brasil: impacto no sistema de justiça criminal. Disponível em: $<$ http://www.idcb.org.br/documentos/ sobre\%20justrestau/construcao_dajust icarestaurativanobrasil2.pdf $>$. Acesso em 25.04.2011).

${ }^{638}$ A tradução para autonomia perde um pouco o significado do termo original empowerment, podendo ser utilizado também o termo "empoderamento". Convém, assim, transcrever o texto em seu vernáculo original, a fim de resgatar tal sentido: "Disempowerment is part of the indignity of being a victim of crime. According to Pettit and Braithwaite's republican theory of criminal justice, a wrong should not be defined as a crime unless it involves some domination of us that reduces our freedom to enjoy life as we choose. It follows that it is important to restore any lost sense of empowerment as a result of crime. [...]. The way that Western legal systems handle crime compounds the disempowerment that victims feel, first at the hands of offenders and then at the hands of a professional, remote justice system that eschews their participation. The lawyers, in the words of Nils Christie 'steal our conflict'. [...]. Restorative justice is deliberative justice; it is about people deliberating over the consequences of a crime, how to deal with them and prevent their recurrence. This contrasts with the professional justice of lawyers deciding which rules apply to a case and then constraining their deliberation within a technical discourse about that rule-application. So restorative justice restores the deliberative control of justice by citizens." (BRAITHWAITE, John. Restorative justice and a better future. Disponível em: < http://www.iirp.org/article_detail.php?article_id=NDk4>. Acesso em: 28 abr. 2011).

639 BRAITHWAITE, John. Restorative justice and a better future. Disponível em: $<$ http://www.iirp.org/article_detail.php?article_id=NDk4>. Acesso em: 28 abr. 2011. 
passava. A autonomia sobre suas vidas, perdida após o delito, pode, assim, de certa forma, ser resgatada por meio dessa posição central que agora passam a ocupar no processo.

O modelo de justiça restaurativa deve contar com a estrutura necessária para viabilizar, em favor das vítimas da infração penal, não somente um tratamento à altura de sua dignidade, a começar pela instância policial, mas também precisa assegurar àquelas e a seus familiares o direito, sem qualquer ônus, à assistência médica, psicológica, social, jurídica e econômica, recordando-se, assim, a amplitude do conceito de restauração. ${ }^{640}$

Dessa forma, o rápido encaminhamento ao sistema de saúde, o acompanhamento psicológico antes, durante e posteriormente ao processo, a pronta disponibilização de uma Defensoria Pública bem estruturada e de qualidade, são algumas das medidas possíveis e bem-vindas no modelo restaurativo ora proposto.

Quanto à reparação de natureza econômica, se esta se mostrar necessária, ${ }^{641}$ caso não possa ser viabilizada diretamente pelo acusado, tendo em vista a constatação corriqueira de que os autores de delitos pertencem às classes sociais menos favorecidas economicamente, poderia o Estado dispor subsidiariamente de fundos públicos para tanto.

Sob as perspectivas do ofensor, o modelo restaurativo mostra-se sobejamente vantajoso se comparado ao modelo tradicional.

$A b$ initio, chama a atenção o propósito de evitar a estigmatização daquele, tão característica no modelo tradicional. BERISTAIN IPIÑA, nesse sentido, constata a necessidade de evolução quanto à concepção acerca do autor do delito, propugnando pela

\footnotetext{
${ }^{640}$ Interessante que se registrem aqui as lições do psicanalista e professor Doutor PAULO ENDO, que recorda as benesses da restauração mesmo para situações traumáticas, em que a dor não pode ser, sob o ponto de vista psicanalítico, ao menos, completamente reparada. Tais benesses seriam a abertura para a conciliação e um importante efeito atenuador sobre a dor: "Se, ao menos do ponto de vista psicanalítico, não há restauração diante do traumático, ao mesmo tempo torna-se fundamental reconhecer que nem toda situação de violência é traumática. Naquelas em que o desdobramento traumático ocorreu sabemos que o fundamental é o reconhecimento dessa marca, desse dolo e desse excesso. Reconhecimento de que o traumático não pode ser completamente reparado. Como reparar a morte de um filho assassinado? De um cidadão agredido e humilhado por forças públicas que, em tese, deveriam protegê-lo? De alguém que teve arrancado violentamente bens que prezava e que lhe custaram esforços e sacrifícios significativos, juntando a perda com o medo social daí decorrentes? Porém no que tange à dor dois elementos são importantes de considerar. Primeiro há uma dimensão da dor provocada por outrem que exige, espera e aguarda a responsabilização desse que a cometeu. É o papel e o poder que tem, resguardadas as proporções e diferenças, o pedido sincero de desculpas em qualquer relação. As desculpas figuram, no microcosmo das relações cotidianas, como um reconhecimento compartilhado de uma ofensa, dor ou mágoa. São pontos de partida para qualquer reconciliação bem sucedida. Há uma dimensão dessa dor que não pode ser transferida, nem delegada, nem atribuída a outrem e que funda o território do irreparável. É isso o que ocorre em todos os traumatismos. Essas dores que carregamos, com pesar, se tornam mais leves se livres de culpa e do imperativo da vingança. Se livres da obrigação de termos de eliminar aquele que ofendeu, magoou ou feriu alguém". (ENDO, Paulo. Psicanálise, direito e justiça restaurativa. Disponível em: $<$ http://www.polemica.uerj.br/pol23/oficinas/arti gos/lipis_2.pdf>. Acesso em 28 abr. 2011).

${ }^{641}$ Não se pode desprezar, nesse ponto, as hipóteses em que as vítimas de delito satisfazem-se com um simples pedido de desculpas da parte do ofensor, dispensando a reparação econômica.
} 
substituição do termo delinquente por vitimário. ${ }^{642}$ Em alguns modelos restaurativos, como o caso do modelo sul-africano Zwelethemba, chega-se até a evitar a distinção vítima/ofensor. ${ }^{643}$

De qualquer forma, sob um modelo restaurativo, seus operadores devem propiciar aos participantes uma postura aberta ao diálogo, o que constitui uma poderosa arma para viabilizar a captação e a percepção dos motivos, dos sentimentos e das necessidades do ofensor - enfim, de sua humanidade - possibilitando a desconstrução dos estigmas e preconceitos existentes.

642 “Los tratadistas de los pueblos primitivos (más o menos primitivos) constatan que éstos calificaban a los delincuentes como demonios, como «malos», como incapaces, indignos de convivir em comunidad. Con la evolución de la Historia, esa condena del autor de los crímenes ha ido perdiendo su carácter radical, mágico, sus rasgos sacros y morales, virulentos, irracionales. Ha ido perdiendo protagonismo en la teoría y en la praxis de la respuesta a los delitos y de la configuración de la pena. Hoy, el policía, el juez y los profesionales de las instituciones prisionales van considerando a los autores de los crímenes como personas menos «malas», menos abyectas, ni exiliables, ni desterrables. La Victimología no gira alrededor del alfa y la omega del Derecho penal tradicional: el delincuente. Éste ha evolucionado totalmente, a lo largo de los siglos. Éste, en los orígenes -recordemos el esquema de FATTAH-era la persona poseída por el demonio...; después, ha sido la persona culpable de haber cometido un crimen, conscientemente, con maldad moral, mayor o menor; merecedor, por esto, de un castigo, e indigno de dialogar con su víctima. Ahora, con el progreso de la ciencia y de la cultura emerge, cada día con más distinción, uma nueva figura, una nueva construcción social, el victimario, en el lugar que antes ocupaba el delincuente. Ese progreso enseña al legislador que no cabe atribuirle al delincuente tanta maldad moral. Ese progreso enseña al Juez que no es Dios y no puede juzgar y condenar al hombre, que sólo puede juzgar sus actos buenos o malos. Que sólo puede conocer la imputación objetiva y subjetiva del acto delictivo (pero no del autor). Hoy, al victimario no le vemos como ayer veíamos al delincuente; hoy le vemos en cuanto autor de un daño a otra u otras personas. Daño que, a veces, pertenece en cierto sentido (aunque no siempre, ni en sentido total, ni exclusivo) a la pareja víctima-victimario, como propugnan, con inteligentes matices, Nils CHRISTIE, Esther GIMÉNEZ-SALINAS, etc. (sic). En la actualidad, al victimario nadie le estigmatiza como un demonio, ni como una persona poseída por el mal, a la que se puede torturar, exiliar o matar. Durante el proceso, y después de él, se le reconocen todas las garantías del Derecho penal tradicional, y -lo que merece gran atención- se le reconoce cierto derecho a dialogar con sus víctimas y de llegar a un acuerdo -más o menos aceptable-por el juez o tribunal.”. (BERISTAIN IPIÑA. Antonio. ¿Evolucionamos hacia las antípodas del derecho penal y la criminología? ¿Evolucionamos hacia la justicia victimal?. Revista Penal, 17, p. 34-58. Disponível em: <http://www.cienciaspenales.net/portal/page/portal/IDP/REVISTA_PENAL_DOCS/Numero $\% 2017 /$ evolucionamos.PDF>. Acesso em: 28 abr. 2011).

${ }^{643} \mathrm{O}$ modelo Zwelethemba iniciou em uma cidade pobre, de mesmo nome, próxima da Cidade do Cabo e desde 2000, quando foi lançado, já foi aplicado em diversas comunidades sul-africanas. Sobre o binário vítima/infrator como causa de exclusão, separação e pré-julgamento dentro de tal modelo: "De acordo com o modelo de Zwelethemba, os indivíduos diretamente envolvidos no conflito são pensados como os participantes ou 'partes' e não como 'vítimas' e o 'infrator'. O binário vítima/infrator é visto dentro do modelo como algo que serve para separar, excluir e pré-julgar. Na prática é comum que um 'caso' trazido à atenção dos pacificadores locais (chamados de 'Comitês de Paz') seja considerado não mais que uma única situação no tempo que deve ser localizado dentro de uma história de conflito entre as partes. Dentro deste contexto, a parte 'infratora' e a parte 'prejudicada' podem (e provavelmente o fazem) mudar de lugar com o passar do tempo. Em outras palavras, o 'infrator' de hoje pode ter sido a 'vítima' de ontem. O modelo tem por base o argumento de que o idioma da 'vítima' e do 'infrator' estrutura o significado do que aconteceu no passado de modo a dificultar para as partes envolvidas entender e articular sua própria realidade ou experiência vivida." (FROESTAD, Jan; SHEARING, Clifford. Prática da justiça: o modelo Zwelethemba de resolução de conflitos. In: SLAKMON, Catherine; DE VITTO, Renato Campos Pinto; PINTO, Renato Sócrates Gomes. (Org.). Justiça restaurativa. Brasília-DF: Ministério da Justiça e Programa das Nações para o Desenvolvimento - PNUD, 2005. p. 79-124, p. 93). 
Esse mesmo diálogo ajuda o próprio ofensor, uma vez tendo contato com a vítima em ambiente propício e com a devida preparação psicológica, a conscientizar-se acerca de sua conduta e de suas respectivas consequências, o que lhe enseja a oportunidade para manifestar arrependimento e apresentar um possível pedido de perdão e uma proposta de reparação, que poderão aliviar a dor das vítimas de delito.

O ofensor beneficia-se também da possibilidade de participar ativamente do diálogo restaurativo, contribuindo, assim, juntamente com os demais protagonistas, para a construção da solução restaurativa, distanciando-se de uma solução imposta por um terceiro.

Por fim, o processo restaurativo não pode estar dissociado de políticas públicas de proteção social, não só em razão dos reclamos da dignidade da pessoa do ofensor, como também com fundamento em uma política de prevenção de novos delitos, ao que se deve conferir especial atenção em um país como o Brasil, em que a exclusão socioeconômica de muitos constitui um fator criminógeno decisivo.

Quanto ao último protagonista, a sociedade, o ideal de restauração pode ser captado já à vista dos próprios efeitos produzidos quanto ao ofensor e às vítimas de delito. Com efeito, as benesses trazidas pelo modelo restaurativo para estes também beneficiam a sociedade como um todo.

Não se deve olvidar que a participação da sociedade no processo penal não pode ser restrita à intervenção estatal, por seus agentes tradicionais - juiz, promotor, defensor público - e dos novos agentes agora disponibilizados - os componentes de uma equipe multidisciplinar de apoio, por exemplo.

Faz-se mister possibilitar também o ingresso no diálogo restaurativo tanto de membros da comunidade - incluindo-se no conceito desta, conforme a distinção trazida por McCOLD, os conceitos de microcomunidade e de macromunidade, ${ }^{644}$ - como o ingresso da sociedade como um todo, no que poderia ser representada por entidades civis idôneas com atuação na defesa de interesses sociais, tais como as que promovem a defesa do meio ambiente, dos direitos do consumidor, dos direitos de minorias, etc., exigindo-se, por óbvio, neste caso, que seus fins sociais guardem pertinência com o caso concreto.

${ }^{644}$ Para McCOLD, a microcomunidade compreenderia pessoas com relação pessoal com ofensor e vítima, como familiares, amigos etc., que em muitos casos poderão enquadrar-se em um conceito mais lato de vítima, conforme apontado na Declaração dos Princípios Básicos de Justiça Relativos às Vítimas da Criminalidade e de Abuso de Poder, da ONU. A macromunidade, por sua vez, abrangeria pessoas que, embora não tenham relação com vítimas e ofensor, convivem no mesmo espaço geográfico desses. (McCOLD, Paul. What is the Role of Community In Restorative Justice Theory and Practice. In: ZEHR, Howard \& TOEWS, Barb (org.). Critical issues in restorative justice. New York: Criminal Justice Press, 2004, p. 155-156). 
Essa abertura do processo restaurativo à participação da sociedade não somente enriquece o diálogo de restauração, mas também estimula o exercício da cidadania, no que contribui para a construção de uma sociedade mais democrática e inclusiva. ${ }^{645}$

Por fim, há de se ponderar que, não obstante as benesses advindas da abertura do modelo restaurativo à participação comunitária e social, essa abertura não poderá contribuir para o enfraquecimento do próprio modelo, o que poderia ser verificado em caso de número excessivo de participantes sociais e comunitários, de modo a prejudicar o diálogo restaurativo, e na hipótese de participação de agentes sociais e comunitários não imbuídos do ideal restaurativo.

Para evitar tais situações, devem ser estabelecidos critérios objetivos que permitam uma seleção para ingresso no modelo restaurativo, bem como a exclusão de participantes cuja atuação se mostre desprovida do ideal restaurativo.

\subsubsection{Justiça restaurativa no Brasil: uma possibilidade}

O tema relativo à justiça restaurativa tem despertado bastante atenção da literatura jurídica brasileira, chegando a ensejar a elaboração de um projeto de Lei: o Projeto n. 7006/2009, que teve trâmite na Câmara dos Deputados e que visava à instituição do "uso facultativo e complementar de procedimentos de justiça restaurativa no sistema de Justiça Criminal”. Esse projeto qual restou arquivado, após parecer do Deputado Antônio Carlos Biscaia, apresentado em 10 de novembro de 2009, em que referido parlamentar, não obstante tenha reconhecido a constitucionalidade material do projeto, entendeu, dentre outros argumentos, pela inconveniência de despenalização em face da tendência nacional para uma maior criminalização de condutas e de acentuação no rigor de penas.

Previa-se, nesse projeto, em qualquer crime ou contravenção penal, a remessa dos autos a um núcleo de justiça restaurativa, pelo juiz da causa, com a anuência do Ministério Público e a manifestação voluntária da vítima e do agressor, e atendidos

\footnotetext{
${ }^{645}$ Para SALIBA, "a participação se apresenta como indispensável em todos os procedimentos, e cinco razões podem ser apontadas, de forma não exaustiva, a justificá-la: $1^{\circ}$ ) para o fortalecimento dos vínculos estabelecidos entre delinquente, vítima e comunidade; $2^{\circ}$ ) para a reinserção social mais efetiva; $3^{\circ}$ ) para a conscientização da importância social do fato pelo desviante, vítima e comunidade; $4^{\circ}$ ) para a conscientização da importância do processo para a comunidade; $5^{\circ}$ ) para a efetiva soberania e cidadania participativa no Estado Democrático de Direito e promotor da justiça social.”. (SALIBA, Marcelo Gonçalves. Justiça restaurativa e paradigma punitivo. Curitiba: Juruá, 2009, p. 163).
} 
requisitos como a personalidade e os antecedentes do infrator, as circunstâncias e consequências da infração.

Estabelecia-se ainda que o acordo restaurativo tanto poderia constituir causa extintiva de punibilidade (art. 11), como que seria necessariamente levado em consideração pelo juiz da causa, por ocasião de sua decisão (art. 16, que previa a introdução do art. 562 no Código de Processo Penal), sem, contudo, apresentar critérios claros para a utilização de uma ou de outra providência. ${ }^{646}$

Dadas suas manifestas vantagens em relação às vítimas de infrações penais, bem como para os demais protagonistas do caso penal, a justiça restaurativa poderia consistir em uma interessante opção a ser desenvolvida no ordenamento jurídico brasileiro, estabelecendo-se em lei critérios para sua aplicação.

Para tanto, poder-se-ia inicialmente, em uma estratégia mais tímida, partir do aproveitamento de foros já existentes no processo penal nacional, como o Juizado de Violência Doméstica e os Juizados Especiais Criminais, e de institutos já disponíveis, como a suspensão condicional do processo e a composição civil de danos, buscando-se uma solução restaurativa para os envolvidos, superando-se, em tais casos, a possibilidade de celebração meramente formal do consenso.

Caso houvesse orientação político-criminal para um desenvolvimento de maior fôlego, poder-se-ia trabalhar a posteriori a ampliação da projeção de práticas restaurativas no processo penal brasileiro, que poderiam ser estendidas a outras categorias de delitos, podendo o acordo restaurativo ensejar efeitos jurídicos diversos, desde a atenuação da pena, em casos mais graves, até a extinção da punibilidade, em infrações de menor gravidade.

Por fim, anote-se não haver pretensão, contudo, de estabelecer as bases para a expansão da prática restaurativa, seja em menor ou maior grau, o que fugiria aos propósitos do presente estudo. Ficam aqui somente apresentados os caracteres gerais da justiça restaurativa, por tratar-se de modelo com forte orientação vitimológica, de necessária referência no estudo sobre a vítima e o consenso no processo penal. A par disso, lança-se o desafio para um maior aprofundamento do estudo sobre a justiça restaurativa, visando à sua aplicação no processo penal brasileiro como poderosa estratégia para o combate à vitimização secundária.

\footnotetext{
${ }^{646}$ Conferir projeto em sua íntegra: BRASIL. Congresso. Câmara dos Deputados. Projeto de Lei $\mathbf{n}^{\mathbf{0}} \mathbf{7 0 0 6 / 0 6 .}$ /<http://www.camara.gov.br/sileg/integras/393836.pdf>. Acesso em: 19 abr. 2011.
} 


\section{CONCLUSÕES}

Seguindo as proposições iniciais, percebem-se as seguintes conclusões com o desenvolvimento do presente estudo:

1) Pode-se identificar, sob um viés histórico que tenha por referência a perspectiva europeia, que as vítimas de infração penal, as quais inicialmente ocupavam a condição de protagonistas na resolução do caso penal, passaram a uma situação de olvidamento e exclusão, em um processo histórico marcado pela formação dos Estados nacionais europeus e pela consolidação das monarquias nacionais. Referido olvidamento somente mereceu um questionamento mais sólido no contexto que se seguiu ao fim da Segunda Guerra Mundial, em que se propugnou uma afirmação dos direitos humanos, que logo se estenderia às vítimas da criminalidade, sob o impulso de um nascente movimento vitimológico. Tal redescoberta da vítima não somente deflagrou a gênese da Vitimologia, ramo destacado da Criminologia, como implicou a edição de diversos documentos internacionais e de copiosa legislação nos mais diversos países, sob o objetivo comum de se viabilizar uma proteção à pessoa da vítima antes inexistente.

2) A concepção de vítima em processo penal encontra grandes dificuldades, a começar pelo fato de que citado termo tem origem criminológica e não jurídica. Atentando-se à necessidade de uma maior valorização da vítima, propõe-se uma concepção, afeta ao processo penal, que compreenda tanto um conceito jurídico-penal estrito - sujeito passivo da infração penal -, já tradicionalmente acolhido, como também o conceito de sujeito prejudicado - que sofre prejuízo patrimonial em decorrência do delito, independentemente de este constituir-se como sujeito passivo. Essa concepção abrangente se justificaria em razão de que ambos, sujeito passivo (com seu correspondente processual, o ofendido) e sujeito prejudicado, fazem-se igualmente merecedores de acolhida e proteção no processo penal, dada a origem comum da gênese de seus interesses: o fato típico-penal caracterizado e sua necessidade em defendê-los processualmente.

3) A redescoberta da vítima no âmbito do processo penal identifica que o sistema de justiça penal, muitas vezes, é responsável por uma nova vitimização 
(vitimização secundária) que se acresce à vitimização primária desencadeada pela infração penal. O resgate da vítima no processo deve partir necessariamente do Princípio da Dignidade da Pessoa Humana que, inicialmente invocado em favor do acusado, também precisa servir de vetor para o aperfeiçoamento de uma maior proteção da vítima, visando a uma maior humanização do processo penal. Para uma melhor análise acerca desse aperfeiçoamento, propõe-se a divisão dos direitos da vítima nas seguintes vertentes: a) direito à proteção; b) direito à informação; c) direito à participação; d) direito à solução consensual do processo, divisão essa que se prestou de arcabouço ao desenvolvimento do presente estudo.

4) Sob o que se denomina de direito à proteção reúnem-se variados direitos e respectivas garantias que tenham em comum o objetivo de proteger a vítima que já se acha em uma situação vulnerável, em decorrência da vitimização primária, e ameaçada ou mesmo já atingida pelos processos de vitimização secundária e terciária. Desdobrando-se em direito a um tratamento digno, direito à proteção da segurança, direito à proteção da privacidade, direito a uma assistência multidisciplinar (médica, psicológica, social, jurídica etc.), direito a amparo econômico pelo Estado, já encontra alguma tutela no ordenamento jurídico brasileiro, a qual, contudo, ainda carece de maior aprimoramento.

5) O direito à informação no âmbito do processo penal reflete bem a situação de exclusão da vítima, já que frequentemente todo o procedimento ganha curso até seu final sem que a vítima seja informada acerca dos atos processuais praticados, relegada que está ao mais completo alheamento. Esse direito, que constitui ponto fulcral para a intervenção da vítima no processo penal, passou a contar com maior proteção com o advento da Lei n. 11.690/2008, que passou a assegurar à vítima o direito de ser informada acerca de alguns atos relativos ao processo. De qualquer forma, o projeto de Código de Processo Penal que hoje se encontra na Câmara dos Deputados, prevê uma maior ampliação da incidência desse direito, aproximando o ordenamento jurídico brasileiro das avançadas disposições da Decisão-quadro do Conselho da União Europeia Relativo ao Estatuto da Vítima em Processo Penal, de 15.03.2001.

6) $\mathrm{O}$ asseguramento efetivo do direito à participação da vítima mostra-se decisivo para combater a vitimização secundária no processo penal. Nesse estudo, para fins didáticos, esse direito compreende as modalidades de: a) condicionamento à manifestação 
da vítima; b) controle sobre a acusação pública; c) concurso ou cooperação; d) reparação de danos civis; e) a participação da vítima na produção de elementos probatórios.

7) $\mathrm{O}$ condicionamento à manifestação da vítima constitui importante modalidade de participação daquela no processo penal, trazendo grandes vantagens tanto para as vítimas da infração penal quanto para a sociedade. Dada a sintonia vitimológica do referido instituto, propõe-se uma ampliação das hipóteses para o condicionamento, de modo a abranger, inclusive, crimes patrimoniais praticados sem violência ou grave ameaça, sugerindo-se, também, com o intuito de se conferir maior importância à vontade da vítima, a possibilidade de retratação da representação até o momento anterior à prolação da sentença.

8) O controle sobre a acusação pública restringe-se, no ordenamento jurídico brasileiro, a três hipóteses: a) recurso administrativo no âmbito do Ministério Público, manejável, em tese, pela vítima, porém, de utilização por demais restrita, pois que aplicável tão somente a ações penais originárias (a depender de regulamentação legal); b) o controle judicial do arquivamento, de uso mais frequente, mas que não conta com nenhuma participação da vítima; e c) a ação penal de iniciativa privada subsidiária, a ser manejada pela vítima na excepcional hipótese de desídia do Ministério Público, mas que oferece como óbices os custos econômicos decorrentes de tal ação e a ausência de poderes investigatórios pela vítima na fase pré-processual. Em face disso e dos profícuos exemplos trazidos pelo direito comparado, propõem-se soluções sob duas vertentes: em relação ao controle sobre a inércia ministerial e quanto ao controle sobre o arquivamento. Quanto à primeira vertente, deve-se pugnar pela implementação de uma política de assistência judiciária em âmbito nacional, que traga concretas melhorias para a estruturação da Defensoria Pública brasileira; quanto à vertente supérstite, deve-se retomar a proposta inicial do projeto de novo Código de Processo Penal (PLS n. 156/09), que afastava o Poder Judiciário do arquivamento da investigação preliminar, possibilitando o controle direto pela vítima do arquivamento promovido pelo promotor de justiça junto à instância revisora competente no âmbito do próprio Ministério Público.

9) O processo penal brasileiro, quanto à reparação de danos civis, encontra-se tradicionalmente filiado ao sistema de separação, o que vem se abrandando nos últimos anos, à vista da instituição da composição civil de danos, trazida pela Lei n. 9.099/95, e 
pela polêmica possibilidade de indenização ex officio a cargo do juízo penal, mediante a fixação de um valor mínimo em prol da vítima, inovação essa trazida pela Lei n. 11.719/2008, a qual modificou a redação dos arts. 387, inciso IV, e 63, parágrafo único, do CPP. Tais inovações, considerando ainda o teor do projeto do novo Código de Processo Penal, já aprovado no Senado Federal, parecem marcar uma transição no processo penal brasileiro rumo ao sistema de adesão.

10) O projeto do novo Código de Processo Penal incorpora no processo penal brasileiro a adesão facultativa, a qual se torna uma opção a mais em favor do sujeito prejudicado, para a satisfação de seu interesse de reparação de danos civis, persistindo as demais possibilidades, a saber, o ajuizamento de ação própria no juízo cível e o título executivo judicial, obtenível a partir da sentença penal condenatória. Com regramento específico, a adesão civil prevista no projeto contempla basicamente a possibilidade de a vítima postular a recomposição de danos, que no contexto do projeto, reduz-se à categoria dos danos morais, opção essa que desperta críticas no presente estudo. Dentre as inovações trazidas, destaca-se a possibilidade de, em se causando transtornos ao regular desenvolvimento do processo penal pela comprovação do dano moral, o juízo penal remeter a questão referente à adesão ao juízo cível.

11) A par do questionamento sobre a inclusão ou não dos danos patrimoniais e dos danos não patrimoniais - não necessariamente compreendidos no conceito de dano moral - como objeto da adesão civil projetada, propõe-se outra questão relativa à legitimidade, em sede de crimes de vítimas difusas, de entidades para a defesa de danos metaindividuais, acenando-se para a possibilidade de se permitir a habilitação de uma única entidade (pública ou privada) para atuar em defesa dos interesses jurídico-penais difusos violados, fazendo-se imprescindível a estipulação legal das hipóteses em que tal habilitação se faça possível, bem como os requisitos para a habilitação da entidade.

12) A participação da vítima poderá ainda verificar-se diretamente na produção de elementos probatórios no âmbito do processo, elementos esses destinados à formação do convencimento dos sujeitos processuais. Nesse caso, percebe-se que a participação e a vontade da vítima na produção de elementos probatórios podem consistir, em si, em elemento estrutural (elemento participativo) ou elemento circunstancial (elemento volitivo) - na acepção de eventual -, da tipicidade processual subjetiva, ou em outros termos, 
elementos imprescindíveis para a configuração de alguns atos processuais destinados à produção de elementos probatórios.

13) Considerando-se que a vítima pode participar na produção de elementos probatórios em meios de provas diversos (pericial, declarações do ofendido etc.), perguntase: poderá a vítima recusar-se a participar da produção probatória? Se não cabível tal recusa, que medidas poderá o Estado adotar? Parte-se do pressuposto de que também vige no processo penal o dever de cooperação processual probatória e que também à vítima, esteja ou não habilitada como assistente no processo penal, se impõe tal dever, não podendo, a princípio, recusar-se a colaborar na produção de elementos de prova. $\mathrm{Na}$ hipótese de recusa pela vítima, sem que haja qualquer motivo justo para tanto, deve-se optar pela produção alternativa de elementos probatórios, a fim de se evitar a vitimização secundária. Não sendo possível, despontam como soluções a condução coercitiva da vítima e comunicação a esta da possível configuração de infração penal (crime de desobediência, previsto no art. 330, do Código Penal) e, por analogia, de infração a dever processual, que poderá lhe acarretar o pagamento de multa (integração por analogia do CPP, arts. 219, 436 e 458, dispositivos estes aplicáveis, a princípio, à testemunha).

14) A modalidade de concurso ou cooperação, no Brasil, é plasmada na instituição do assistente do Ministério Público, que deve receber uma abordagem respeitando-se a autonomia do processo penal em relação ao processo civil. Em tal modalidade, podem ser identificados, como móvel da atuação da vítima, interesses de natureza jurídica, precisando-se superar qualquer restrição do interesse jurídico do assistente a uma ótica patrimonialista.

15) O procedimento de habilitação do assistente, previsto no CPP, traz grande vantagens: para o processo, porque a habilitação serve para garantir um controle específico e efetivo sobre a legitimidade do interessado e, na hipótese de titulares de legitimação supletiva, para proporcionar um controle sobre a ordem de preferência (art. 31), e para o assistente, porque uma vez assim constituído, a habilitação lhe assegura a possibilidade de atuar durante todo o processo, firmando-se em seu favor uma posição estável (e não meramente eventual) de sujeito processual, no que se lhe assegura o direito de ser notificado para comparecer a todos os atos processuais. 
16) A assistência no processo penal, tal qual se encontra atualmente conformada no processo penal brasileiro, parece ter ficado a meio caminho em relação às exigências do movimento vitimológico. De fato, se por um lado, busca evitar o completo alijamento processual da vítima, entretanto, por outro, assegura a esta uma participação secundária e supletiva, que a torna um sujeito processual de categoria inferior, como bem atesta sua atuação recursal limitada e supletiva e sua mera faculdade de proposição de prova (CPP, art. 271 , caput e seu $\left.\S 1^{\circ}\right)$.

17) $\mathrm{O}$ fundamento para a participação da vítima no processo penal deve ser buscado no direito fundamental à tutela jurisdicional efetiva, que por sua vez, tem por base principiológica o Princípio da Dignidade da Pessoa Humana. Essa participação da vítima deve-se enfatizar - não pode restringir-se a uma atuação meramente formal, aos moldes de um convidado de pedra, mas precisa ser efetiva, sob pena de esvaziamento do próprio direito fundamental à tutela jurisdicional.

18) A bilateralidade dos direitos implica que, no processo penal, também à vítima devem ser reconhecidos direitos anteriormente tidos por exclusivos do acusado. A bilateralidade dos direitos, que traz consigo uma reflexão sobre a relatividade dos direitos do acusado no processo penal, não pode, porém, atender a uma política criminal vitimocentrista, implicando a supressão de qualquer dos direitos do acusado.

19) Sob a ótica ora proposta, que compreende a necessária existência de três polos de interesses no processo penal (sociedade, ofensor e vítima), o ingresso da vítima e a atribuição crescente de suas faculdades processuais, a princípio, não ensejam desequilíbrio no processo. Os diversos princípios e regras processuais que incidiam em prol do equilíbrio no confronto entre Ministério Público e acusado deverão continuar a incidir também quanto ao confronto entre vítima e acusado, vedando-se, agora, à vítima, contar com armas jurídicas que também não sejam disponibilizadas ao acusado. Entretanto, deve-se atentar para o equívoco decorrente de uma ampliação excessiva no conceito de vítima e na legitimidade do assistente, que poderiam converter o polo de interesses das vítimas em um superpolo, redundando em grande desproporção de forças no processo penal. 
20) A análise do art. 129, inciso I, da Constituição Federal de 1988 leva à constatação da existência de dois direitos distintos conflitantes entre si: o direito da vítima à participação em concurso ou cooperação e o direito do acusado a uma acusação por um órgão estatal isento, o Ministério Público. Tal dispositivo pode ser interpretado - sugere-se - da seguinte forma: em sede de ações penais de iniciativa pública, a privatividade estatal deve restringir-se à dedução da pretensão acusatória em juízo, de modo que após tal dedução, o exercício das faculdades processuais pudesse ser garantido tanto ao Ministério Público quanto à vítima, os quais poderiam agir com independência entre si. Tal interpretação traz vantagens manifestas tanto para a vítima quanto para o acusado.

21) Atentando-se paras as limitações relativas à assistência no processo penal brasileiro, defende-se uma atuação do assistente própria de parte, em tudo autônoma, no que se refere à atuação do Ministério Público, respeitada somente a exclusividade deste na proposição da pretensão acusatória em ações penais de iniciativa pública. Assim, ficam algumas proposições, como a notificação inicial da vítima (determinada) para, se o quiser, habilitar-se como assistente, e a afirmação e implementação do direito à prova e do direito recursal amplo e autônomo.

22) A diversão mostra-se como uma tentativa de solução, no âmbito do processo penal, do problema da crise contemporânea do Direito Penal. A par de uma concepção mais absoluta de diversão, realizada fora do âmbito do Poder Judiciário, que poderia redundar mesmo em uma justiça privada, uma concepção mais restrita, denominada de diversificação/simplificação procedimental, pode ocorrer mediante os seguintes mecanismos básicos: mecanismos que conduzem ao encerramento antecipado do processo, que levam à supressão de fases dos procedimentos ordinários e os que representam uma reorganização do procedimento ordinário. Pode-se ainda concluir que a diversificação pressupõe um juízo de oportunidade ou, em outros termos, somente pode haver diversificação dentro do contexto de um juízo de oportunidade conferido pela lei. Dentre as formas de diversificação, importa a este estudo aquelas que tenham como critério o consenso.

23) O consenso no processo penal não se mostrava originariamente presente no modelo clássico de processo desenvolvido no civil law, contudo, tem adentrado no processo penal deste último sistema, operando uma modificação extraordinária: a 
substituição de um modelo de justiça penal vertical, imposta, por um modelo de justiça penal horizontal, convergente, modelo esse que tem determina uma nova leitura das bases que fundamentam o processo penal, baseando-se este estudo em institutos consensuais que contem necessariamente com a participação da vítima.

24) O consenso, já incorporado ao ordenamento jurídico processual penal brasileiro pelo disposto na Constituição Federal, art. 98, inciso I, representa para a vítima um notável avanço dentro do modelo clássico de processo penal continental. Resgatada de seu tradicional alheamento do processo penal, pelo consenso, a vítima torna-se protagonista processual. Refere-se aqui a um verdadeiro direito à solução consensual do processo, devendo ser criados espaços para juízos de discricionariedade, em que seja possível o consenso entre as partes, incluindo-se aí necessariamente a vítima, que deverá, assistida juridicamente, participar com o acusado de tratativas visando a um desfecho consensual do caso.

25) O processo penal brasileiro prevê a existência de três institutos consensuais: a transação penal, a composição civil de danos - aplicáveis exclusivamente no âmbito do microssistema da Lei n. 9.099/95 - e a suspensão condicional do processo, aplicável a infrações penais cuja pena privativa abstrata mínima seja inferior ou igual a um ano. $\mathrm{Na}$ verdade, o consenso atualmente disponibilizado no processo brasileiro está a merecer algumas alterações a fim de ensejar um atendimento às exigências da dignidade da vítima. Assim, pode-se partir de uma reformulação simples da suspensão condicional do processo, a fim de que a vítima, juntamente com o Ministério Público e o acusado, seja protagonista do acordo, bem como se pode estender o mecanismo da composição civil de danos a infrações penais fora do âmbito do Juizado Especial Criminal.

26) A vítima, que parece ter encontrado nos modelos consensuais uma chance de resgate no processo penal, encontra na justiça restaurativa um protagonismo indiscutível, considerando a especial atenção que desperta nos modelos processuais restaurativos. A justiça restaurativa implica a criação de novos modelos que tem como móvel um processo comunicativo, resolutivo e recriador, superando o modelo tradicional centrado sobre a aplicação de uma pena. 
27) A justiça restaurativa poderia ser implementada no ordenamento jurídico brasileiro, a princípio, de modo mais tópico e imediato, em que se aproveitariam institutos hoje disponíveis, como a suspensão condicional do processo, realizando-se algumas poucas modificações legislativas. Caso houvesse orientação político-criminal para um desenvolvimento de maior fôlego, poder-se-ia trabalhar a posteriori a ampliação da projeção de práticas restaurativas no processo penal brasileiro, que poderiam ser estendidas a outras categorias de delitos, podendo o acordo restaurativo ensejar efeitos jurídicos diversos, desde a atenuação da pena, em casos mais graves, até a extinção da punibilidade, em infrações de menor gravidade.

28) Por fim, apresenta-se, de forma conclusiva, após exaustivo estudo, a necessidade de abrir espaço à tutela processual penal da vítima, sugerindo-se uma aproximação entre o Princípio da Dignidade da Pessoa Humana e a vítima, passando essa a ocupar verdadeiramente um papel de sujeito de direitos também no processo penal. 


\section{REFERÊNCIAS $^{647}$}

ABREU E SILVA, Roberto. Sentença condenatória criminal e a reparação de danos: a estratégia de atuação da vítima. Rio de Janeiro: Lumen Juris, 2010.

AIMONETTO, Maria Gabriella. Azione penale e ruolo della vittima in Italia e Francia. L’indice Penale, Padova, v. 29, n. 1, p.185-211, genn./apr. 1995.

ALMEIDA, Maria Rosa Crucho de. As relações entre vítimas e sistema de justiça criminal em Portugal. Revista Portuguesa de Ciência Criminal, Coimbra, v. 3, n. 1, p. 103-116, jan./mar. 1993.

ALMEIDA JÚNIOR, João Mendes de. O processo criminal brasileiro. 3. ed. augmentada. Rio de Janeiro: Typ. Baptista de Souza, 1920. 2v.

ANDRADE, Manuel da Costa. Consenso e oportunidade. In: Jornadas de direito processual: o novo código de processo penal. Lisboa: C.E.J., 1989, p. 319-358.

ANDRADE, Mauro Fonseca. Sistemas processuais penais e seus princípios reitores. Curitiba: Juruá, 2010.

ANITUA, Gabriel Ignacio. Histórias dos pensamentos criminológicos. Tradução de Sérgio Lamarão. Rio de Janeiro: Revan, 2008. (Coleção pensamento criminológico, 15).

ARDUÍNO, Ileana; LITVACHKY, Paul; MAXIT, Margarita. O ministério público na Argentina. Tradução de Victor Ferreira. In: DIAS, João Paulo; AZEVEDO, Rodrigo Ghiringhelli de. (Coord.). O papel do ministério público: estudo comparado dos países latino-americanos. Coimbra: Almedina, 2008, p. 247-308.

ARGENTINA. Código procesal penal de la Nación. Disponível em: <http://www.infoleg.gov.ar/infolegInternet/anexos/0-4999/383/texact.htm>. Acesso em: 05 out. 2010.

ASSIS, Araken de. Eficácia civil da sentença penal. 2. ed. rev. atual. amp. São Paulo: Revista dos Tribunais, 2000.

AZEVEDO, Rodrigo Ghiringhelli de. O Ministério Público no Brasil. In: DIAS, João Paulo; _ (Coord.). O papel do ministério público: estudo comparado dos países latino-americanos. Coimbra: Almedina, 2008, p. 223-248.

BAAMONDE. Xulio Ferreiro. La víctima en el proceso penal. Madrid: La Ley, 2005.

BADARÓ, Gustavo Henrique Righi Ivahy. Correlação entre acusação e sentença. 2. ed. São Paulo: Revista dos Tribunais, 2009.

${ }^{647}$ De acordo com a Associação Brasileira de Normas Técnicas. NBR 6023. 
Ônus da prova no processo penal. São Paulo: Revista dos Tribunais, 2003.

Provas atípicas e provas anômalas: inadmissibilidade da substituição da prova testemunhal pela juntada de declarações escritas de quem poderia ser testemunha. In: YARSHELL, Flávio Luiz; MORAES, Maurício Zanoide de (Coord.). Estudos em homenagem à professora Ada Pellegrini Grinover. São Paulo: DPJ Editora, 2005, p. 341-352.

BARCELLOS, Ana Paula. A eficácia jurídica dos princípios constitucionais: o princípio da dignidade da pessoa humana. Rio de Janeiro: Renovar, 2002.

BARROS, Flaviane de Magalhães. A participação da vítima no processo penal. Rio de Janeiro: Lumen Juris, 2008.

. Direito das vítimas e sua participação no processo penal: a análise do PLS 156/09 a partir de uma interpretação constitucional. In: COUTINHO, Jacinto Nelson de Miranda; CARVALHO, Luis Gustavo Grandinetti Castanho de. (Org.). O novo processo penal à luz da constituição (análise crítica do projeto de lei $\mathbf{n}^{0}$ 156/2009, do Senado Federal). Rio de Janeiro: Lumen Juris, 2010, p. 321-331.

BECCARIA, Cesare. Dos delitos e das penas. São Paulo: Quartier Latin, 2005.

BERISTAIN IPIÑA. Antonio. Derecho penal, criminología y victimología. Curitiba: Juruá, 2007.

¿Evolucionamos hacia las antípodas del derecho penal y la criminología? ¿Evolucionamos hacia la justicia victimal? Revista Penal, 17, p. 34-58. Disponível em: <http:www.cienciaspenales.net/portaç/page/portal/IDP/REVISTA_PENAL_DOCS/Numer O\%2017/evolucionamos.PDF>. Acesso em: 28 abr. 2011.

. Nuevo processo penal desde las víctimas. In: MESSUTI, Ana; SAMPEDRO ARRUBLA, Julio Andrés. (Coord.). La administración de la justicia en los albores del tercer milenio. Buenos Aires: Editorial Universidad, 2001, p. 17-33.

. Proceso penal y víctimas; pasado, presente y futuro. In: Politica criminal, derechos humanos y sistemas jurídicos en el siglo XXI: volumen de homenaje al prof. Dr. Pedro R. David en su 72. aniversario (21/7/1929). Buenos Aires: Buenos Aires: De Palma, 2001, p. 123-148.

BERTOLINO, Pedro J. La situación de la víctima del delito en el proceso penal de la Argentina. In: BERMÚDEZ, Victor Hugo et al. La víctima en el proceso penal: su régimen legal en Argentina, Bolivia, Brasil, Chile, Paraguay, Uruguay. Prefácio de Ada Pellegrini Grinover. Buenos Aires: Depalma, 1997, p. 1-68.

BITTENCOURT, Cezar Roberto. Tratado de direito penal: parte geral. 9. ed. São Paulo: Saraiva, 2004. v. 1.

BITTENCOURT, Edgar de Moura. Vítima. 2. ed. São Paulo: LEUD, 1978. 
BRAITHWAITE, John. Restorative justice and a better future. Disponível em: <http://www.iirp.org/article_detail.php?article_id=NDk4>. Acesso em: 28 abr. 2011.

BRASIL. Congresso. Câmara dos Deputados. Projeto de Lei $\mathbf{n}^{\mathbf{0}}$ 7006/06. <http://www.camara.gov.br/sileg/integras/393836.pdf>. Acesso em: 19 abr. 2011.

Congresso. Senado. Projeto de Lei do Senado $n^{\mathbf{0}}$ 156/2009: redação final. Disponível em <http://www.senado.gov.br/atividade/materia/getPDF.asp?t=85509\&tp=1>. Acesso em: 15 mar. 2011.

Congresso. Senado. Projeto de Lei do Senado no 156/2009: texto inicial. Disponível em: <http://legis.senado.gov.br/mate-pdf/58503.pdf>. Acesso em: 21 out. 2010.

Congresso. Senado. Projeto de Lei do Senado n $^{\mathbf{2}}$ 269/2003. Disponível em: <http://www.senado.gov.br/atividade/materia/getPDF.asp?t=68877\&tp=1>. Acesso em: 23 dez. 2011.

. Conselho Nacional de Justiça. Nota técnica 10/210. Disponível em: <http://www.cnj.jus.br/atos-administrativos/atos-da-presidencia/317-notas-tecnicas/11221nota-tecnica-no-102010a>. Acesso em 15.01.2010

Presidência da República. Secretaria de Direitos Humanos. Sistema nacional de assistência a vítimas e testemunhas ameaçadas. Disponível em: $<$ http://www.direitoshumanos.gov.br/protecao/Id_prot_testemunha/Id_prot_sist>. Acesso em: 22 dez. 2011.

Superior Tribunal de Justiça. Recurso Especial $n^{\circ} 1.057 .274$, do Tribunal de Justiça do Rio Grande do Sul. Brasília, DF, 1 de dezembro de 2009. Disponível em: http://www.stj.jus.br/SCON/jurisprudencia/doc.jsp?livre=REsp+1057274\&\&b=ACOR\&p $=$ true $\& \mathrm{t}=\& \mathrm{l}=10 \& \mathrm{i}=1>$. Acesso em: 26 out. 2010 .

Supremo Tribunal Federal. HC n. 102085, do STJ. Brasília/DF, 18.12.2009. Disponível: <http://www.stf.jus.br/portal/processo/verProcessoDetalhe.asp?incidente $=381$ 6006>. Acesso 13 jan. 2012.

Supremo Tribunal Federal. HC n. 104356, do STJ. Brasília/DF, 08.06.2010. Disponível: <http://www.stf.jus.br/portal/jurisprudencia/listarJurisprudencia.asp?s1=\%22ar quivamento+impl\%EDcito\%22+e+penal\&base=baseAcordaos $>$. Acesso em: 13 jan. 2012.

CABRAL, Antônio do Passo. O valor mínimo da indenização cível fixado na sentença condenatória penal: notas sobre o novo art. 387, IV do CPP. Revista da EMERJ. Rio de Janeiro, v. 13, n. 49, p. 302-328, jan./mar. 2010.

CALAMANDREI, Piero. Eles, os juízes, vistos por nós, os advogados. 7. ed. Lisboa: Clássica, 1985.

CALHAU, Lélio Braga. Vítima e direito penal. 2. ed. Belo Horizonte: Melhoramentos, 2003. 
CÂMARA, Guilherme Costa. Programa de política criminal orientado para a vítima do crime. São Paulo: Editora Revista dos Tribunais; Coimbra: Coimbra Editora, 2008.

CAMPOS, Carlos Rodríguez. Aspectos historicos y reflexiones sobre la victimología y el derecho victimal em México. Disponível em: 〈http://www.funvic.org/vic_mex.pdf $>$. Acesso em: 29 dez. 2011.

CARNELUTTI, Francesco. Instituições do processo civil. Tradução de Adrián Sotero de Witt Batista. Campinas: Servanda, 1999. v. 1.

CARVALHO, Luís Gustavo Grandinetti de. Quando o público e o privado se encontram no projeto: assistência, indenização e composição. In: COUTINHO, Jacinto Nelson de Miranda; ( (Org.). O novo processo penal à luz da constituição (análise crítica do projeto de lei $\mathbf{n}^{\mathbf{0}}$ 156/2009, do Senado Federal). Rio de Janeiro: Lumen Juris, 2010, p. 315-320.

Processo penal e constituição: princípios constitucionais do processo penal. Rio de Janeiro: Lumen Juris, 2006.

COMPARATO, Fábio Konder. A afirmação histórica dos direitos humanos. 6. ed. São Paulo: Saraiva, 2010.

Ética. São Paulo: Companhia das Letras, 2006.

CÓRDOBA, Fernando. La posición de la víctima en el nuevo código procesal penal de la nación. Buenos Aires: Del Puerto, 1993.

COSTA, José Francisco de Faria. Diversão (desjudiciarização) e mediação: que rumos? Boletim da Faculdade de Direito da Universidade de Coimbra, v.61, p. 91-158, 1985.

COSTA, Mário Júlio de. História do direito português. 3. ed. Coimbra: Almedina, 2009.

COSTA, Paula Bajer Fernandes Martins da. Igualdade no direito processual penal brasileiro. São Paulo: Revista dos Tribunais, 2001.

CUNHA, Damião da. A participação dos particulares no exercício da acção penal: alguns aspectos. Revista Portuguesa de Ciência Criminal, Coimbra, v. 8, n. 4, p.593-660, out./dez.1998.

CUNHA JÚNIOR, Dirley da. Curso de direito constitucional. 2. ed. rev. amp. atual. Salvador: Jus Podium, 2008.

D’ALBORA, Francisco J. El querelante y la víctima. Ciencias penales contemporáneas: Revista de Derecho Penal, Procesal Penal y Criminologia. Mendoza, 2001, v. 1, n. 2.

DANZIGER, Leila. Shoah ou holocausto - a aporia dos nomes. Disponível em: <http://leiladanziger.com/text/32shoah.pdf>. Acesso em: 09 fev. 2011.

DEMERCIAN, Pedro Henrique. Regime jurídico do ministério público no processo penal. São Paulo: Verbatim, 2009. 
DEZEM, Guilherme Madeira. Da prova penal: tipo processual, provas típicas e atípicas. Campinas: Millenium, 2008.

DIAS, Jorge de Figueiredo. Direito processual penal. 1. ed. 1974, reimpressão. Coimbra: Coimbra editora, 2004.

DUARTE, Ronnie Preuss. Garantia de acesso à justiça: os direitos processuais fundamentais. Coimbra: Coimbra Editora, 2007.

ENDO, Paulo. Psicanálise, direito e justiça restaurativa. Disponível em: <http://www.polemica.uerj.br/pol23/oficinas/artigos/lipis_2.pdf>. Acesso em 28 abr. 2011.

ESER, Albin. Acerca del renacimiento de la víctima en el procedimiento penal: tendencias nacionales e internacionales. Tradução de Fabrício O. Guariglia e Fernando J. Córdoba. In: MAIER, Julio B. J. (Comp.). De los delitos y de las víctimas. Buenos Aires: Ad Hoc, 2001. p.13-52.

. Bene giuridico e vittima del reatto: prevalenza dell'uno sull'altra? Rivista Italiana di Diritto e Procedura Penale, Milão, ano XL, fasc. 1, p. 1061-1084, genn./mar. 1997.

ESTATUTO DE ROMA DE LA CORTE PENAL. Disponível em: <http://www.icccpi.int>. Acesso em: 17 jan. 2012.

ESTEFAM, André. Crimes sexuais: comentários à Lei n. 12.015/2009. São Paulo: Saraiva, 2009

ESTRAMPES, Manuel Miranda. La 'mínima actividad probatoria' en el proceso penal. Barcelona: JMB, 1997.

FABRI, Marco; CAVALLINI, Daniela. O ministério público em Itália. Tradução de Eurico Ventura Pereira. In: DIAS, João Paulo; AZEVEDO, Rodrigo Ghiringhelli de. (Coord.). O papel do ministério público: estudo comparado dos países latino-americanos. Coimbra: Almedina, 2008. p. 167-221.

FAZZALARI, Elio. Instituições de direito processual. Tradução de Elaine Nassif. Campinas: Bookseller, 2006.

FELICIANO, Guilherme Guimarães. Direito à prova e dignidade humana: cooperação e proporcionalidade em provas condicionadas à disposição física da pessoa humana (abordagem comparativa). São Paulo: LTr, 2007.

FERNANDES, Antônio Scarance. O papel da vítima no processo criminal. São Paulo: Malheiros, 1995.

Processo penal constitucional. 6. ed. rev. atualiz. ampl. São Paulo: Revista dos Tribunais, 2010.

Teoria geral do procedimento e o procedimento no processo penal. São Paulo: Revista dos Tribunais, 2005. 
. ; MARQUES, Oswaldo Henrique Duek. O Estado na reparação do dano à vítima do crime. Justitia, São Paulo, v. 53, n. 156, p. 25-34. out./dez. 1991.

FERNANDES, Fernando. O processo penal como instrumento de política criminal. Coimbra: Almedina, 2008. (Coleção teses).

FERNANDES, Giovana Polo. A vítima do crime no processo penal. Revista da Procuradoria Geral do Estado de São Paulo, São Paulo, 59/60, p.221-240, jan./dez. 2004.

FERRAJOLI, Luigi. Direito e razão: teoria do garantismo penal. Tradução de Ana Paulo Zomer, Fauzi Hassan Choukr, Juarez Tavares e Luiz Flávio Gomes. São Paulo: Revista dos Tribunais, 2002.

FERREIRA, Francisco Amado. Justiça restaurativa: natureza, finalidade e instrumentos. Coimbra: Coimbra Editora, 2006.

FERRI, Enrico. Princípios de direito criminal. Tradução de Paolo Capitanio. 2. ed. Campinas: Bookseller, 1999.

FOUCAULT, Michel, Vigiar e punir. Tradução de Raquel Ramalhete, 25. ed. Petrópolis: Editora Vozes, 2009.

FROESTAD, Jan; SHEARING, Clifford. Prática da justiça: o modelo Zwelethemba de resolução de conflitos. In: SLAKMON, Catherine; DE VITTO, Renato Campos Pinto; PINTO, Renato Sócrates Gomes. (Org.). Justiça restaurativa. Brasília-DF: Ministério da Justiça e Programa das Nações para o Desenvolvimento - PNUD, 2005. p. 79-124.

GAROFOLI, Vincenzo. Diritto processuale penale. Milão: Giuffrè, 2008.

GIACOMOLLI, Nereu José. Legalidade, oportunidade e consenso no processo penal na perspectiva das garantias constitucionais: Alemanha, Espanha, Itália, Portugal e Brasil. Porto Alegre: Livraria do Advogado, 2006.

GODOY, Cláudio Luiz Bueno de. A liberdade de imprensa e os direitos de personalidade. 2. ed. São Paulo: Atlas, 2008.

GOMES, Luiz Flávio. Justiça penal restaurativa: conciliação, mediação e negociação. Disponível em: <http://www.universojuridico.com.br/publicacoes/doutrinas/3880/JUSTIC A_PENAL_RESTAURATIVA_CONCILIACAO_MEDIACAO_E_NEGOCIACAO>.Ac esso em: 28 abr. 2011.

GOMES, Luiz Flávio; MAZZUOLI, Valério de Oliveira. Comentários à convenção americana sobre direitos humanos: Pacto San José da Costa Rica. 2. ed. rev. atualiz. e ampl. São Paulo: Revista dos Tribunais, 2009. (Coleção ciências criminais).

GOMES FILHO, Antônio Magalhães. Direito à prova no processo penal. São Paulo: Revista dos Tribunais, 1997. 
Notas sobre a terminologia da prova (reflexos no processo penal brasileiro). In: YARSHELL, Flávio Luiz; MORAES, Maurício Zanoide de (Coord.). Estudos em homenagem à professora Ada Pellegrini Grinover. São Paulo: DPJ Editora, 2005, p. 303-318.

GORGULHO, Gilberto da Silva; STORNIOLO, Ivo; ANDERSON, Ana Flora. Bíblia de Jerusalém. São Paulo: Paulus, 2002.

GRECO FILHO, Vicente. Manual de processo penal. 8. ed. São Paulo: Saraiva, 2010.

GRINOVER, Ada Pellegrini; GOMES FILHO, Antônio Magalhães; FERNANDES, Antônio Scarance. Recursos no processo penal: teoria geral dos recursos, recursos em espécie, ações de impugnação, reclamação aos tribunais. 6. ed. ver. atualiz. e ampl. São Paulo: Revista dos Tribunais, 2009.

HAMILTON, Sérgio Demoro. Temas de processo penal. Rio de Janeiro: Lumen Juris, 1998.

HEREDIA, José Raúl. Lectura constitucional del proceso penal. Córdoba: Ediciones del Copista, 2010.

HIRSCH, Hans-Joachim. La posición del ofendido en el derecho penal, con la especial referencia a la reparación. Cuadernos de Política Criminal, Madrid, n. 42, p. 561-575, 1990.

ILLUMINATI, Giulio. La presunzione d'innocenza dell'imputato. Bologna: Zanichelli, 1984.

INSTITUTO DOS ADVOGADOS DO BRASIL. Disponível em: <http://www.iabnacional.org.br/IMG/pdf/doc-2377.pdf>. Acesso em: 15 jan. 2010.

ITÁLIA. Codice di procedura penale. Disponível em: <http://www.altalex.com/index.php?idnot=2011 >. Acesso em: 09 jun. 2011.

JACCOUD, Mylène. Princípios, tendências e procedimentos que cercam a justiça restaurativa. In: SLAKMON, Catherine; DE VITTO, Renato Campos Pinto; PINTO, Renato Sócrates Gomes. (Org.). Justiça restaurativa. Brasília-DF: Ministério da Justiça e Programa das Nações para o Desenvolvimento - PNUD, 2005. p. 163-186.

JACINTO, Francisco Teodósio. O modelo de processo penal entre o inquisitório e o acusatório: repensar a intervenção judicial na comprovação da decisão de arquivamento do inquérito. Disponível em <http://www.stj.pt/nsrepo/cont/Coloquios/TeodosioJacinto_vf. pdf.> Acesso em: 12 abr. 2011.

JARDIM, Afrânio Silva. Direito processual penal. 11. ed. Rio de Janeiro: Forense, 2007.

KAMIMURA, Akemi. Os direitos das vítimas de violência nos sistemas internacionais de proteção aos direitos humanos: breve análise do sistema global e interamericano. Disponível em: <http://gedi.objectis.net/artigos/Akemi_Kamimura_-_paper.pdf/viewp>. Acesso em: 17 jan. 2012. 
KEHDI, André Pires de Andrade. $O$ sigilo da ação penal: aspectos gerais. In: FERNANDES, Antônio Scarance; ALMEIDA, José Raul Gavião de; MORAES, Maurício Zanoide de. (Coord.). Sigilo no processo penal: eficiência e garantismo. São Paulo: Revista dos Tribunais, 2008, p. 57-95.

KINDHÄUSER, Urs. (et. al.). Criminalidad, evolución del derecho penal y crítica al derecho penal en la actualidad. Buenos Aires: Del Puerto, 2009.

LAFER, Celso. A internacionalização dos direitos humanos: Constituição, racismo e relações internacionais. Bauru: Manole, 2005.

LANZÓN, Román P. La intervención de la víctima en el proceso penal y su derecho a actuar como querellante. In: GUZMÁN, Nicolás. (Coord.). El sistema penal en las sentencias recientes de los órganos interamericanos de protección de los derechos humanos. Buenos Aires: Ad Hoc, 2009. p. 223-250.

LARONGA, Antonio. Le prove atipiche nel processo penale. Padova: CEDAM, 2009.

LEÃO, Nilzardo Carneiro. A vítima e o processo penal. In: KOSOVSKI, Ester; PIEDADE JÚNIOR, Heitor (Coord.). Temas de vitimologia II. Rio de Janeiro: Lumen Juris, 2001. p. 103-110.

LOPES JÚNIOR, Aury. Direito processual penal e sua conformidade constitucional. 5. ed. rev. atual. Rio de Janeiro: Lumen Juris, 2010. 2 v.

MAISONNAVE, Germán Aller. Derecho victimal. Revista Ibero-Americana de Ciências Penais, Porto Alegre, v. 2, n. 3, p.103-111, mai./ago. 2001.

MALAN, Diogo Rudge. Direito ao confronto no processo penal. Rio de Janeiro: Lumen Juris, 2009.

MALVIDO, Maria de La Luz Lima. Derecho victimal. In: MARCHIORI, Hilda. (Coord.). La víctima desde una perspectiva criminológica: asistencia victimológica. Córdoba: Editora Universitaria Integral, 2004.

MANISCALCO, Marzia. L’azione civile nel processo penale. Milão: CEDAM, 2006.

MANZANERA, Luis Rodriguez. Victimología. 12. ed. Cidade do México: Porrúa, 2010.

MARINONI, Luiz Guilherme. Técnica processual e tutela dos direitos. 3. ed. rev. atualiz. São Paulo: Revista dos Tribunais, 2010.

MARTÍNEZ ARRIETA, Andrés. La víctima en el proceso penal. Revista Actualidad Penal, Madrid, v. 1, 1/26, p.41-48, semanal. 1990.

MAZZILLI, Hugo Nigro. Introdução ao ministério público. 7. ed. rev. atual. São Paulo: Saraiva, 2008.

MAZZILLI NETO, Ranieri. Os caminhos do sistema penal. Rio de Janeiro: Revan, 2007. 
McCOLD, Paul. What is the Role of Community In Restorative Justice Theory and Practice. In: ZEHR, Howard \& TOEWS, Barb (org.). Critical issues in restorative justice. New York: Criminal Justice Press, 2004.

MEDEIROS NETO, Xisto Tiago de. Dano moral coletivo. 2. ed. LTr, 2007.

MEIRA, José de Castro. A experiência alienígena quanto ao ressarcimento do dano "ex delicto". BDJur, Brasília/DF, 01 abr. 2008. Disponível em: <http://bdjur.stj.gov.br/dspace/handle/2011/16769>. Disponível em: <http://bdjur.jus.br> Acesso em: 15 set. 2010.

MENDES, Paulo de Sousa. Estatuto do arguido e posição processual da vítima. Revista Portuguesa de Ciência Criminal, Coimbra, n. 4, p. 601-612, out./dez. 2007.

MOLINA, Antonio Garcia-Pablos de. Criminologia: uma introdução a seus fundamentos teóricos. Tradução de Luiz Flávio Gomes. São Paulo: Revista dos Tribunais, 1992.

MOLINO, Fernanda Brusa. Justiça Restaurativa: possibilidade ou utopia? Âmbito Jurídico, Rio Grande, 71, 01 fev. 2009.Disponível em: <http://www.ambitojuridico.com.br/site/index.php?n_link=revista_artigos_leitura\&artigo_id=6689>. Acesso em 18 abr. 2011.

MORAES, Maurício Zanoide de. Publicidade e proporcionalidade na persecução penal brasileira. In: FERNANDES, Antônio Scarance; ALMEIDA, José Raul Gavião de; MORAES, Maurício Zanoide de. (Coord.). Sigilo no processo penal: eficiência e garantismo. São Paulo: Revista dos Tribunais, 2008.

MOREIRA, Jairo Cruz. A intervenção do ministério público no processo civil à luz da constituição. Belo Horizonte: Del Rey, 2009.

NAMER, Sabrina E. La autonomia del querelante y el derecho a la jurisdición. In: GUZMÁN, Nicolás. (Coord.). El sistema penal en las sentencias recientes de los órganos interamericanos de protección de los derechos humanos. Buenos Aires: Ad Hoc, 2009. p. 319-352.

OLIVEIRA, Ana Sofia Schmidt. A vítima e o direito penal: uma abordagem do movimento vitimológico e de seu impacto no direito penal. São Paulo: Revista dos Tribunais, 1999.

OLIVEIRA, Edmundo. Vitimologia e direito penal: o crime precipitado pela vítima. 4. ed. Rio de Janeiro: Forense, 2005.

OLIVEIRA, Eugênio Pacelli. Curso de processo penal. 11. ed. Rio de Janeiro: Lumen Juris, 2009.

Processo e hermenêutica na tutela penal dos direitos fundamentais. 2. ed. rev. atual. Rio de Janeiro: Lumen Juris, 2009. 
OLIVEIRA, Gilberto Callado de. O conceito de acusação. São Paulo: Revista dos Tribunais, 1996.

PANDOLFI, Oscar Raúl. El derecho del imputado a um acusador penal único (o a un solo discurso acusatorio del que defenderse). Córdoba: Ediciones del Copista, 2010.

PATENTE, Antônio Francisco. O assistente da acusação. Belo Horizonte: Del Rey, 2003.

PENTEADO, Jaques Camargo. Acusação, defesa e julgamento. Campinas: Millenium, 2001.

PEREIRA, Jane Reis Gonçalves. Interpretação constitucional e direitos fundamentais: uma contribuição ao estudo das restrições aos direitos fundamentais na perspectiva da teoria dos princípios. Rio de Janeiro: Renovar, 2006.

PIEDADE JÚNIOR, Heitor. Vitimologia: evolução no tempo e no espaço. Rio de Janeiro: Freitas Bastos, 1993.

PINTO, Renato Sócrates Gomes. A construção da justiça restaurativa no Brasil: impacto no sistema de justiça criminal. Disponível em: <http://www.idcb.org.br/document os/sobre\%20justrestau/construcao_dajusticarestaurativanobrasil2.pdf >. Acesso em: 25 abr. 2011.

PIOVESAN, Flávia. Direitos humanos e o direito internacional constitucional. 12. ed. rev. atualiz. São Paulo: Saraiva, 2011.

PORTUGAL. Código de processo penal. Disponível: <http://www.portolegal.com/CPP en.htm>. Acesso em: 09 jun. 2011.

RAMOS, André de Carvalho. O diálogo das Cortes: o Supremo Tribunal Federal e a Corte Interamericana de Direitos Humanos. In: AMARAL JÚNIOR. Alberto (coord.). O STF e o direito internacional dos direitos humanos. São Paulo: Quartier Latin, 2009, p. 805-850.

Processo internacional de direitos humanos. Rio de Janeiro: Renovar, 2002.

RANGEL, Paulo. Direito processual penal. 8. ed. rev. ampl. atualiz. Rio de Janeiro: Lumen Juris, 2004.

REALE JÚNIOR, Miguel. Teoria do delito. 2. ed. São Paulo: Revista dos Tribunais, 2000 .

RIBEIRO, Evandro de Aguiar; TEREZO, Cristina Figueiredo. Evolução do Sistema Interamericano de Direitos Humanos: o novo Direito Processual Internacional dos Direitos Humanos. Revista do Ministério Público do Estado do Pará, Belém, v.1, p. 77-90, dez. 2010 .

RODRIGUES, Roger de Melo. Adesão civil e "dano moral coletivo" no projeto do novo CPP. In Boletim IBCCRIM. São Paulo: IBCCRIM, ano 18, n. 216, p.16-17, nov. 2010. 
RODRIGUEZ GARCIA, Nicolás. Análisis de la nueva regulación del 'principio del consenso' en el procedimiento abreviado español. In: COSTA ANDRADE, Manuel da et al. (Org.). Liber discipulorum para Jorge de Figueiredo Dias. Coimbra, Coimbra Editora, 2003, p. 1455-1500.

ROIG TORRES, Margarita. Algunos apuntes sobre la evolución histórica de la tutela jurídica de la víctima del delito. Estudios Penales y Criminológicos, Santiago de Compostela, n. 22, p.153-308, 1999/2000.

ROSA, Alexandre Moraes da; SILVEIRA FILHO, Sylvio Lourenço da. Para um processo penal democrático: crítica à metástase do sistema de controle social. Rio de Janeiro: Lumen Juris, 2008.

ROXIN, Claus; ARZT, Gunther; TIEDEMANN, Klaus; Introdução ao direito penal e ao direito processual penal. Tradução de Gercélia Batista de Oliveira Mendes. Belo Horizonte: Del Rey, 2007.

SALIBA, Marcelo Gonçalves. Justiça restaurativa e paradigma punitivo. Curitiba: Juruá, 2009.

SAMPEDRO ARRUBLA, Júlio Andrés. Pensar el processo penal. El principio de oportunidad, un instrumento para la humanización del processo desde las víctimas. Cuadernos de Doctrina y Jurisprudencia penal: criminologia, teoría y práxis. Buenos Aires, v. 1, n. 1, p. 99-117, 2002.

Por la humanización del proceso penal. In: MESSUTI, Ana. (Coord.). Perspectivas criminológicas en el umbral del tercer milenio. Montevidéu: Fundación de Cultura Universitaria, 1998. p. 75-82.

SANTANA, Selma Pereira de. Justiça restaurativa: a reparação como consequência jurídico-penal autônoma do delito. Rio de Janeiro: Lumen Juris, 2010.

SANTOS. Cláudia Cruz. A "redescoberta" da vítima e o direito processual penal português. In: ANDRADE, Manuel da Costa Andrade; ANTUNES, Maria João; SOUSA; Susana Aires de. (Org.). Estudos em homenagem ao prof. doutor Jorge de Figueiredo Dias. Coimbra: Coimbra Editora, 2010. v. 3. p. 1133-1153.

SCHÜNEMANN, Bernd. Obras. Buenos Aires: Rubinzal-Culzoni, 2009. v. 2. (Colección autores de derecho penal).

SILVA, José Afonso da. Curso de direito constitucional positivo. 16 ed. São Paulo: Malheiros, 1999.

SILVA SÁNCHEZ, Jesús-María. Aproximação ao direito penal contemporâneo. Trad. Roberto Barbosa Alves. São Paulo: Revista dos Tribunais, 2011. (Coleção Direito e ciências afins, v.7).

SOARES, Rogério Aguiar Munhoz. Tutela jurisdicional diferenciada: tutelas de urgência e medidas liminares em geral. São Paulo: Malheiros, 2000. 
SOUZA, Diego Fajardo Maranha Leão de; LEITE, Rosimeire Ventura. O sigilo no processo criminal e o interesse público à informação. In: FERNANDES, Antônio Scarance; ALMEIDA, José Raul Gavião de; MORAES, Maurício Zanoide de. (Coord). Sigilo no processo penal: eficiência e garantismo. São Paulo: Revista dos Tribunais, 2008, p. 203-238.

STEINER, Sylvia. A convenção americana e sua integração ao processo penal brasileiro. São Paulo: Revista dos Tribunais, 2000.

SUBIJANA ZUNZUNEGUI, Ignacio José. Los derechos de la víctima: su plasmación en el proceso penal. Revista del Poder Judicial, Madrid, n. 54, p. 165-210, 1999.

TONINI, Paolo. A prova no processo penal italiano. Tradução de Alexandra Martins e Daniela Mróz. São Paulo: Revista dos Tribunais, 2002.

TOURINHO FILHO, Fernando da Costa. Comentários à lei dos juizados especiais criminais. 7. ed., São Paulo: Saraiva, 2010.

TUCCI, José Rogério Cruz e; AZEVEDO, Luiz Carlos de. Lições da história do processo civil lusitano. São Paulo: Revista dos Tribunais, 2009.

TUCCI, Rogério Lauria. Direitos e garantias individuais no processo penal brasileiro. 3. ed. rev. atual. amp. São Paulo: Revista dos Tribunais, 2009.

Lineamentos do processo penal romano. São Paulo: Buhatsky, 1976.

- Teoria do direito processual: jurisdição, ação e processo penal (estudo sistemático). São Paulo: Revista dos Tribunais, 2002.

UN Convention on Justice and Support for Victims of Crime and Abuse of. Disponível em: <http://www.apav.pt/portal/pdf/convention.pdf>. Acesso em: 14 set. 2011.

VANZOLINI, Maria Patrícia. O Tribunal Penal Internacional e o processo de judicialização do Direito Internacional dos Direitos Humanos. In: PIOVESAN, Flávia; IKAWA, Daniela (Coord.). Direitos humanos: fundamento, proteção e implementação. Curitiba: Juruá, 2007, Vol. 2, p. 242-262.

VEGA GONZÁLEZ, Paulina. O papel das vítimas nos procedimentos perante o Tribunal penal internacional: seus direitos e as primeiras decisões do Tribunal. SUR: Revista Internacional de Direitos Humanos, São Paulo, v. 3, n. 5, p. 18-41, jul./dez. 2006. Disponível em: <http://bdjur.stj.gov.br/dspace/handle/2011/22644>. Acesso em: 8 jun. 2009.

VICTIM SUPPORT EUROPE. Disponível em: <http://www.victimsupporteurope.eu/>. Acesso em: 14 set. 2011.

VIEIRA, Ana Lúcia Menezes. Processo penal e mídia. São Paulo: Revista dos Tribunais, 2003. 
VILAR, Silvia Barona. Seguridad, celeridade y justicia penal. Valencia: Tirant lo Blanch, 2004.

VOGLER, Richard. Justiça consensual e processo penal. In: CHOUKR, Fauzi Hassan; AMBOS, Kai. (Coord.). Processo penal e estado de direito. Campinas: Edicamp, 2002.

XAVIER DE ALBUQUERQUE, F.M. A assistência no processo penal brasileiro. Revista Brasileira de Criminologia e Direito Penal, Rio de Janeiro, v. 3, n. 12, p. 89-98, jan./mar. 1966.

ZAFFARONI, Eugenio Raúl; PIERANGELLI, José Henrique. Manual de direito penal brasileiro: parte geral. 8. ed. rev. atual. São Paulo: Revista dos Tribunais, 2009. v. 1.

ZIYADE, Fátima. O assistente da acusação. Porto Alegre: Livraria do Advogado, 1993. 